\title{
Molecular detection of foodborne pathogens
}

Josefsen, Mathilde Hartmann

Publication date:

2009

Document version

Publisher's PDF, also known as Version of record

Citation for published version (APA):

Josefsen, M. H. (2009). Molecular detection of foodborne pathogens. Samfundslitteratur. 
FACULTY OF LIFE SCIENCES

UNIVERSITY OF COPENHAGEN

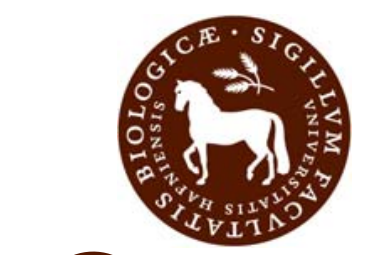

Molecular Detection of Foodborne Pathogens

PhD thesis by Mathilde Hartmann Josefsen

DEPARTMENT OF VETERINARY DISEASE BIOLOGY

\& THE NATIONAL FOOD INSTITUTE, 


\section{Faculty of Life Sciences}

\section{Supervisors:}

Professor John Elmerdahl Olsen, Department of Veterinary Disease Biology, Faculty of Life Sciences, University of Copenhagen

Professor Jeffrey Hoorfar, National Food Institute, Technical University of Denmark Post. Doc. Charlotta Löfström, National Food Institute, Technical University of Denmark Senior Scientist Dorte Lau Baggesen, National Food Institute, Technical University of Denmark

Title of Ph.D. Thesis:

Molecular Detection of Foodborne Pathogens

Ph.D. thesis 2009 C Mathilde Hartmann Josefsen

Department of Veterinary Disease Biology

Faculty of Life Sciences, University of Copenhagen

Stigbøjlen 4, 1870 Frederiksberg C, Denmark

Submitted on 31 July 2009

ISBN 978-87-7611-298-1

Printed by Samfundslitteratur Grafik, Frederiksberg, Denmark 


\section{Abstract}

Salmonella and Campylobacter are recognised as some of the most important foodborne pathogens worldwide. Human infections have wide health and socioeconomic consequences. Lots of effort has been devoted to increase the knowledge on the prevalence, transmission routes and persistence of these pathogens in the food chain, in order to improve intervention strategies and make more effective the control of production lines and single food items. To serve this purpose, rapid and reliable detection and quantification methods are imperative.

The culture-based standard methods currently applied for detection and enumeration of Salmonella and Campylobacter are time-consuming and laborious. They lack specificity and do not enable detection of viable but non-culturable (VBNC) bacteria.

The focus of the present thesis has been development and validation of PCR-based detection methods for Salmonella and Campylobacter. A conventional PCR-based method for detection of Campylobacter in chicken carcass rinse following $20 \mathrm{~h}$ of enrichment in Bolton broth was successfully compared to the ISO standard culture-based method (10272) on 68 naturally infected chickens. The method was subsequently validated on artificially inoculated pig carcass swab and chicken carcass rinse samples in an international collaborative trial including 12 participating laboratories.

A real-time PCR-based method was developed from the conventional method, and this compared favourably to the ISO standard culture-based method (10272) on 12 artificially inoculated and 66 naturally infected chicken carcass rinse samples. The robustness, detection probability, precision, amplification efficiency and linear range of the method were evaluated on two different thermal cyclers, and the method was proven suitable for quantification. Furthermore, a linear relationship $\left(R^{2}=0.94\right)$ was established between the threshold cycle values obtained in real-time PCR after enrichment and the culture-based enumeration. This real-time PCR method was validated according to the recommendations of the Nordic Organisation for Validation of Alternative Microbiological Methods (NordVal) in comparative and collaborative trials, and was approved for detection of Campylobacter in chicken neck skin, cloacal swab and boot swab samples.

A comparison study on probe chemistries for real-time PCR was performed on locked nucleic acid (LNA), minor groove binder (MGB), Scorpion and TaqMan probes. The LNA probe was shown to be the most sensitive probe chemistry in the real-time PCR assay for detection of 
Campylobacter, producing the highest amplification efficiency. Choice of probe chemistry was found to impact the sensitivity of PCR assays, and should be considered in an optimisation strategy.

Finally, the real-time PCR method was evaluated for direct quantification of Campylobacter in chicken carcass rinse samples. A propidium monoazide (PMA) sample treatment was incorporated into the method, enabling PCR detection of viable Campylobacter only. A strong correlation $\left(R^{2}=0.84\right)$ was obtained between the Campylobacter counts obtained by PMA-PCR and culture, indicating that the method presents as a reliable tool for producing accurate quantitative data on viable Campylobacter. DNA from dead cells was not detected by the proposed method, however, it recognised the infectious potential of the VBNC state, and would thus be able to assess the outcome and impact of increasingly applied postslaughter reduction strategies.

A real-time PCR-based method for detection of Salmonella was optimised following a diversified approach to enable the shortest time of analysis possible. Positive effects of the optimisation strategy were observed from increasing 1 ) the sampling volume from the preenrichment, 2) the paramagnetic particles applied in the DNA extraction procedure, and 3) the amount of DNA template in the PCR. This method was subsequently validated according to the recommendations of NordVal in comparative and collaborative trials and was approved as an alternative method for detection of Salmonella in chicken neck skin, minced meat and pig carcass swabs.

In conclusion, this thesis presents the development and validation of real-time PCR methods for detection of Salmonella and Campylobacter, and for Campylobacter also quantification of viable cells only. These validated methods can help the dissemination and implementation of PCR-based methods in control laboratories, and thereby contribute to improved food safety. 


\section{Sammendrag (Danish)}

Salmonella og Campylobacter er blandt de vigtigste fødevarebårne patogener. Humane infektioner har vidtrækkende sundhedsmæssige og økonomiske konsekvenser. Indsatsen for at tilvejebringe viden om prævalens, smitteveje og persistens i fødevarekæden er derfor intensiv, med det formål at forbedre interventionsstrategier og effektivisere kontrollen med fødevareproduktionen og de enkelte fødevarer. Til dette formål er det $n \varnothing$ dvendigt at have hurtige og sikre metoder til påvisning og kvantificering til rådighed.

I dag anvendes dyrkningsbaserede standardmetoder til påvisning og kvantificering af Salmonella og Campylobacter, som både er tids- og arbejdskrævende. De har mangler hvad angår specificitet, og er ikke i stand til at detektere levende-men-ikke-dyrkbare bakterier.

Denne Ph.d.-afhandlings fokus har været udvikling og validering af PCR-baserede detektionsmetoder til Salmonella og Campylobacter. En konventionel PCR-metode til at detektere Campylobacter i kyllingerens efter 20 timers opformering i Bolton bouillon blev med tilfredsstillende resultat sammenlignet med den dyrkningsbaserede ISO-standard (10272) på 68 naturligt inficerede kyllinger. Metoden blev efterfølgende valideret på spikede svinesvaber prøver og kyllingerens $i$ en international kollaborativ test med 12 deltagende laboratorier.

En real-time PCR-baseret metode blev udviklet fra den konventionelle metode, og denne blev sammenlignet succesfuldt med den dyrkningsbaserede ISO-standard (10272) på 12 spikede og 66 naturligt inficerede kyllingerens-prøver. Metodens robusthed, detektionssandsynlighed, præcision, amplifikationseffektivitet og lineære rækkevidde blev evalueret på to forskellige thermocyklere, og den blev fundet egnet til kvantificering. Ydermere kunne der etableres en lineær sammenhæng $\left(R^{2}=0,94\right)$ mellem de opnåede Ctværdier og den dyrkningsbaserede kvantificering.

Denne real-time PCR metode blev valideret i henhold til anbefalingerne fra den Nordiske Organisation for Validering af Alternative Mikrobiologiske Metoder (NordVal) i komparative og kollaborative studier, og blev godkendt til detektion af Campylobacter i kyllingehalsskind, kloaksvabere og sokkeprøver.

Et real-time PCR sammenligningsstudie blev udført med probekemierne locked nucleic acid (LNA), minor groove binder (MGB), Scorpion og TaqMan. LNA proben viste sig at være den mest sensitive til detektion af Campylobacter-DNA, og samtidig var det også her den højeste 
amplifikationseffektivitet blev opnået. Valg af probekemi blev påvist at have indflydelse på PCR-sensitiviteten og burde overvejes i optimeringssammenhæng.

Endelig blev real-time PCR-metoden evalueret mhp. direkte kvantificering af Campylobacter i kyllingerens. Med det formål kun at detektere levende Campylobacter celler blev en propidiummonoazid prøvebehandling inkorporeret i metoden. En stærk korrelation mellem kvantificering af Campylobacter vha. PCR og dyrkning blev fundet $\left(R^{2}=0,84\right)$, hvilket understregede metodens anvendelighed til at tilvejebringe nøjagtige kvantitative data. DNA fra døde celler blev ikke detekteret, men metoden var i stand til at anerkende det infektiøse potentiale af levende-men-ikke-dyrkbare celler, og vil derfor kunne anvendes til at evaluere resultatet og dermed effekten af diverse reduktionsstrategier.

En real-time PCR-baseret metode til detektion af Salmonella blev optimeret efter et flerstrenget princip, for at reducere analysetiden mest muligt. Positive effekter sås som følge af et forøget 1) prøvevolumen fra præopformering, 2) indhold af paramagnetiske partikler i DNA-ekstraktionen og endelig 3) DNA-volumen i PCR. Metoden blev efterfølgende valideret i komparative og kollaborative studier i henhold til anbefalingerne fra NordVal, og blev godkendt som en alternativ metode til detektion af Salmonella i kyllingehalsskind, hakket $k \emptyset d$ og svinesvabere.

Afhandlingen præsenterer udviklingen og valideringen af real-time PCR-baserede metoder til detektion af Salmonella og Campylobacter, og for Campylobacter ydermere til kvantificering af levende bakterier. De validerede metoder kan lette udbredelsen og implementeringen af PCR-baseret detektion i kontrollaboratorier, og dermed bidrage til forbedret fødevaresikkerhed. 


\section{List of manuscripts}

The present thesis is build upon the following manuscripts with permission from authors and copyright holders.

I: Josefsen, M.H., P.S. Lübeck, F. Hansen, and J. Hoorfar. 2004. Towards an international standard for PCR-based detection of foodborne thermotolerant campylobacters: interaction of enrichment media and pre-PCR treatment on carcass rinse samples. J. Microbiol. Methods 58:39-48.

II: Josefsen, M.H., N. Cook, M. D'Agostino, F. Hansen, M. Wagner, K. Demnerova, A.E. Heuvelink, P.T. Tassios, H. Lindmark, V. Kmet, M. Barbanera, P. Fach, S. Loncarevic, and J. Hoorfar. 2004. Validation of a PCR-based method for detection of foodborne thermotolerant campylobacters in a multicenter collaborative trial. Appl. Environ. Micrbiol. 70:4379-4383.

III: Josefsen, M.H., N.R. Jacobsen, and J. Hoorfar. 2004. Enrichment followed by quantitative PCR both for rapid detection and as a tool for quantitative risk assessment of foodborne thermotolerant campylobacters. Appl. Environ. Micrbiol. 70:3588-3592.

IV: Krause, M., M.H. Josefsen, M. Lund, N.R. Jacobsen, L. Brorsen, M. Moos, A. Stockmarr, and J. Hoorfar. 2006. Comparative, collaborative, and on-site validation of a TaqMan PCR method as a tool for certified production of fresh, Campylobacter-free chickens. Appl. Environ. Microbiol. 72:5463-5468.

V: Josefsen, M.H., M. Krause, F. Hansen, and J. Hoorfar. 2007. Optimization of a 12-hour TaqMan PCR-based method for detection of Salmonella bacteria in meat. Appl. Environ. Microbiol. 73:3040-3048.

VI: Löfström, C., M. Krause, M.H. Josefsen, F. Hansen and J. Hoorfar. 2009. Validation of a same-day real-time PCR method for screening of meat and carcass swabs for Salmonella. BMC Microbiol. 9.

VII: Josefsen, M.H., C. Löfström, H.M. Sommer and J. Hoorfar. 2009. Diagnostic PCR: Comparative sensitivity of four probe chemistries. Mol. Cell. Probes 23:201-203. 
VIII: Josefsen, M.H., C. Löfström, T.B. Hansen, L.S. Christensen, J.E. Olsen and J. Hoorfar. 2009. Quantification of viable Campylobacter in fresh chicken carcass rinse by real-time PCR and propidium monoazide as a novel strategy for risk assessment. In Preparation for Appl. Environ. Microbiol.

Book chapter

Josefsen, M.H., C. Löfström, K.E.P. Olsen, K. Mølbak and J. Hoorfar. 2009. Salmonella. In: Molecular detection of human pathogens. Don Liu (Ed.). Taylor \& Francis CRC Press. Submitted. 


\section{Abbreviations}

$\begin{array}{ll}\text { AC } & \text { accuracy } \\ \text { AE } & \text { amplification efficiency } \\ \text { AFNOR } & \text { Association Francaise de Normalisation } \\ \text { AHB } & \text { Abeyta-Hunt-Bark } \\ \text { AOACl } & \text { Association of Official Analytical Chemists International } \\ \text { ATCC } & \text { American Type Culture Collection } \\ a_{w} & \text { water activity } \\ \text { BA } & \text { blood agar } \\ \text { BAM } & \text { bacteriological analytical manual } \\ \text { BB } & \text { Bolton broth } \\ \text { BHI } & \text { brain heart infusion } \\ \text { BHQ } & \text { black hole quencher } \\ \text { Bp } & \text { base pairs } \\ \text { BPW } & \text { buffered peptone water } \\ \text { BSA } & \text { bovine serum albumin } \\ \text { CCUG } & \text { Culture Collection University of Göteborg } \\ \text { CD } & \text { committee draft } \\ \text { CDT } & \text { cytolethal distending toxin } \\ \text { CFU } & \text { colony forming units } \\ \text { CI } & \text { confidence interval } \\ \text { COR } & \text { concordance odds ratio } \\ \text { CPS } & \text { capsular polysaccharide } \\ \text { Ct } & \text { threshold cycle } \\ \text { CV } & \text { coefficient of variation } \\ \triangle \text { Rn } & \text { normalised reporter signal } \\ \text { DFFE } & \text { Directorate for Food, Fisheries and Agri Business } \\ \text { DFVF } & \text { Danish Food and Veterinary Research } \\ \text { DIN } & \text { Deutsches Institute für Normung } \\ \text { DIS } & \text { draft international standard } \\ \text { DMSO } & \text { dimethyl sulfoxide } \\ \text { DNA } & \text { deoxyribonucleic acid } \\ \text { dNTP } & \text { deoxyribonucleotide triphosphate } \\ \text { dTTP } & \text { deoxythymidine triphosphate } \\ \text { DTU } & \text { Technical University of Denmark } \\ \text { dUTP } & \text { deoxyuridine triphosphate } \\ \text { EDTA } & \text { ethylene diamine tetraacetic acid } \\ \text { EFSA } & \text { European Food Safety Agency } \\ \text { EMA } & \text { ethidium monoazide } \\ \text { FU } & \text { European Union } \\ \text { FAM } & \text { carboxy fluorescein } \\ \text { FDIS } & \text { ferrous sulphate, sodium metabisulphite, sodium pyruvate } \\ & \text { US Food and Drug Administration } \\ \text { FAft international standard }\end{array}$




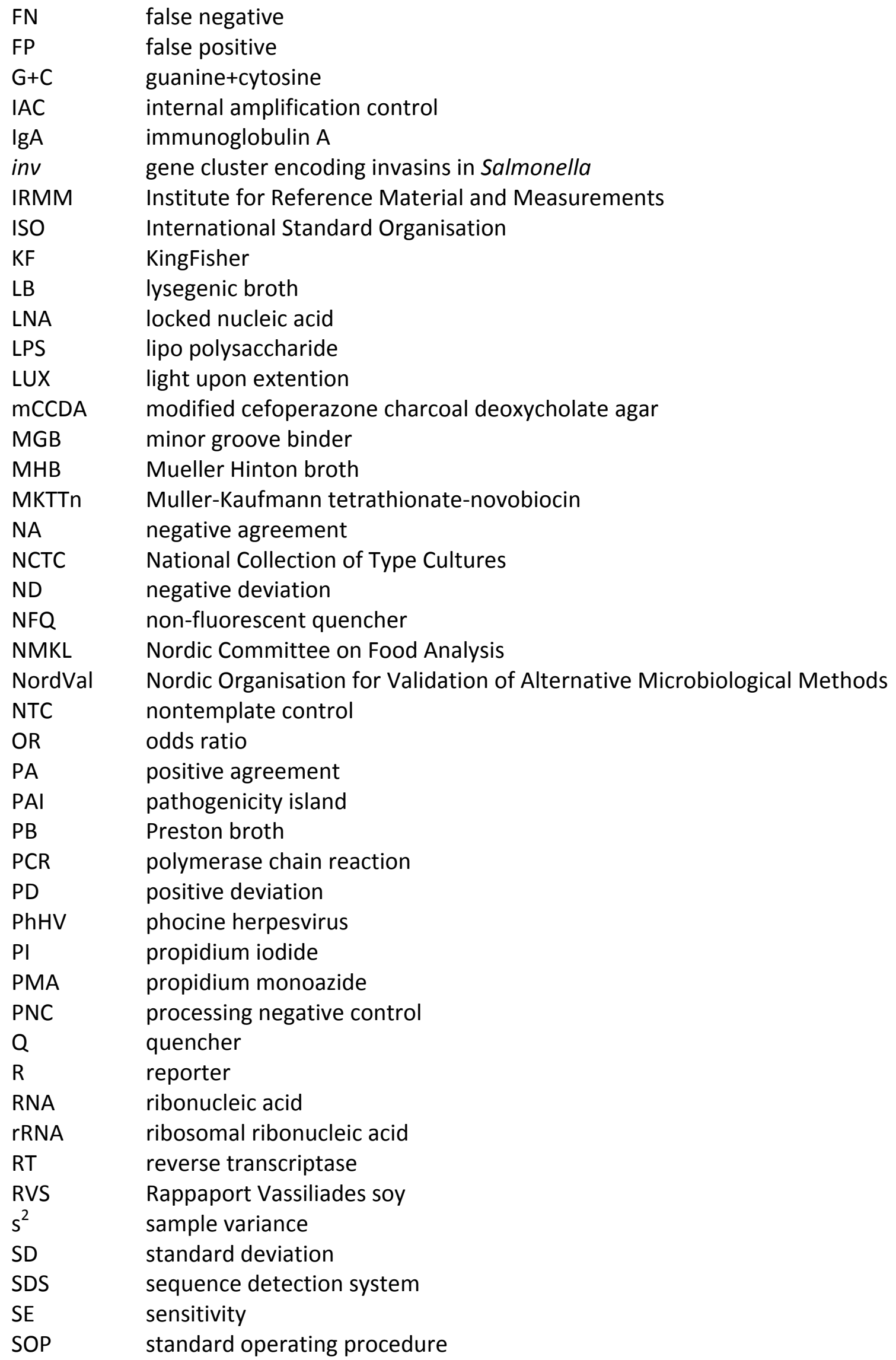


SP

SPI

SSI

TAMRA

Tth

TP

TSB

T3SS

U

UNG

VBNC

WHO

specificity

Salmonella pathogenicity island

Statens Seruminstitut

carboxy tetramethyl rhodamine

Thermus thermophilus

true positive

tryptone soya broth

type 3 secretion system

unit

uracil- $N$-glycosylase

viable but non-culturable

World Health Organisation 


\section{Contents}

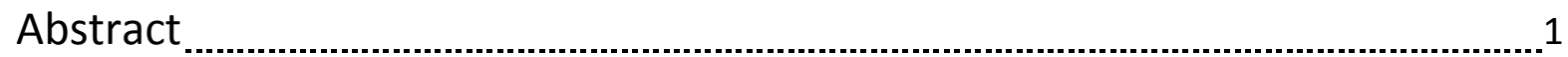

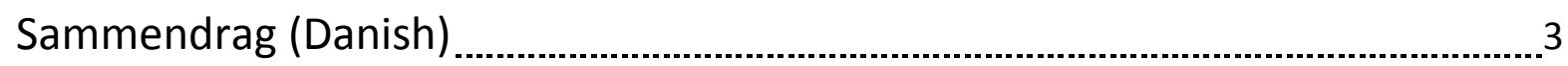

List of manuscripts

Abbreviations

1. Introduction 11

2. Background on Salmonella and Campylobacter ............................................ 13

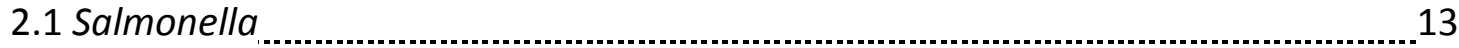

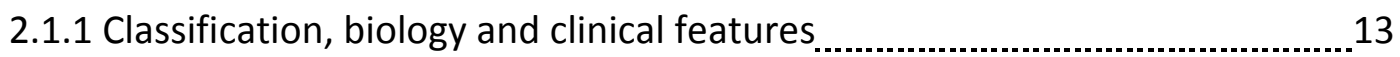

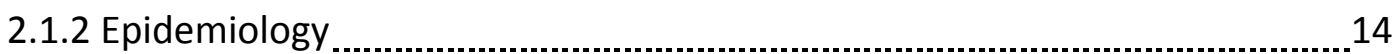

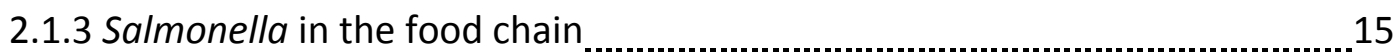

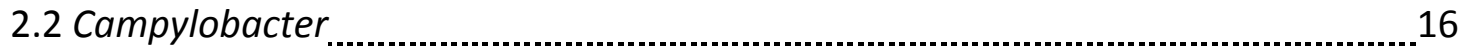

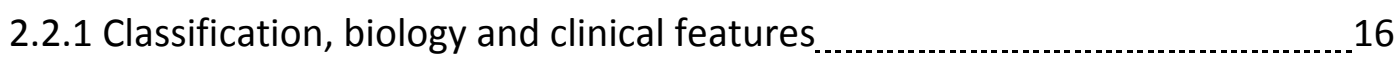

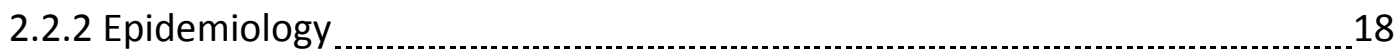

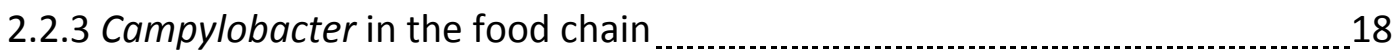

3. Culture-based detection $\ldots$

3.1 Salmonella

3.2 Campylobacter

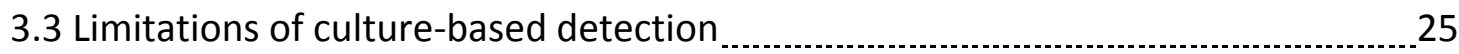

4. Detection by PCR 26

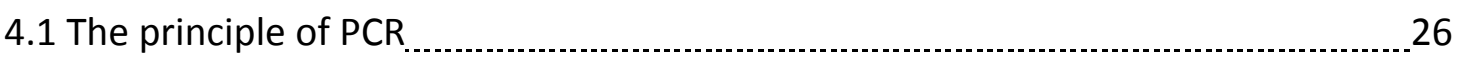

4.2 PCR inhibition

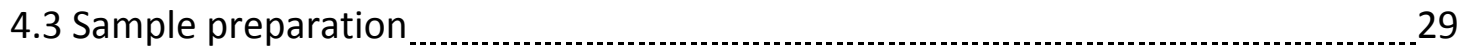

4.4 Strategies for optimisation of real-time PCR-based methods _....................... 30

4.4.1 Optimisation of sample preparation ....................................................... 30

4.4.2 Optimisation of PCR master mix and probe chemistry _........................... 31

4.5 Validation for routine diagnosis ........................................................................... 33

4.6 PCR-detection of Salmonella

4.7 PCR-detection of Campylobacter ................................................................... 37

5. Quantification of Campylobacter

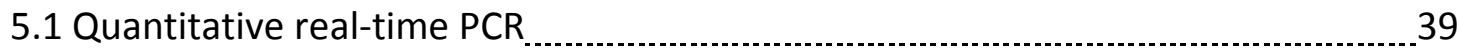

5.2 Differentiation of viable and dead Campylobacter $\quad 42$

5.3 Post-slaughter quantification of viable Campylobacter on chickens ..................... 45

6. Concluding remarks

7. Acknowledgements

8. References 51 


\section{Introduction}

Foodborne infections are a serious problem, affecting public health worldwide. Salmonella and Campylobacter are two of the most important foodborne pathogens $(17,21,170)$. The discomfort, possible sequelae, clinical cost and working hours lost following infection, presents a serious problem from both a health and a socioeconomic perspective. Salmonella has been estimated to be responsible for 1.3 billion human infections annually (136), and in the majority of the developed word, Campylobacter infections have exceeded the number of Salmonella infections and become the leading cause of bacterial gastrointestinal disease (134).

Both pathogens are zoonotic agents, transmitted from animals and animal products to humans. The presence of these pathogens in the food chain entails the necessity of intervention strategies, as well as reliable and efficient control of production lines and single food items. Methods for detection, enumeration and characterisation are imperative to improve knowledge on prevalence, route of transmission and persistence in the food chain, as well as to enhance the control and intervention strategies of Salmonella and Campylobacter, and to ensure the safety of the food items available for consumers.

Until recently, microbiological methods for detection and enumeration of Salmonella and Campylobacter relied solely on culture. Standardised reference culture methods for these organisms have been issued by the national and international standardisation organisations, and are applied in control laboratories throughout the world. The culture-based approach is however not optimal, due to poor specificity, lack of detection of viable but non-culturable (VBNC) cells, and a time-consuming and labour-intensive nature. From a food safety point of view, these culture-based methods fail the purpose of producing rapid and reliable results, which can ensure the microbiological safety of products being released to the consumer.

PCR has revolutionised microbiological methods for detection of foodborne pathogens. Compared to culture-based methods, PCR offers valuable advantages regarding speed, sensitivity, specificity, cost and potential for automation (173). However, a lack of standardisation, validation and ability to differentiate between viable and dead microorganisms, has hampered the implementation of PCR-based methods in the control laboratories (78). 
Focusing on Salmonella and Campylobacter, the objective of this thesis was to improve molecular-based diagnostic tools for risk assessment. To enable their application in assessing the effect of reduction strategies, and use in control of the food chain, and thereby ensure a rapid and reliable detection of these pathogens.

This thesis describes the development of molecular-based methods for detection of Salmonella and Campylobacter. It is build upon eight manuscripts regarding the evolving process of identifying, developing, optimising and finally validating PCR-based methods for Salmonella and Campylobacter. The methods proposed in this thesis have been developed in close collaboration with the Danish meat industry, with their requirements kept in mind to ensure the justification of the methods in the relevant control laboratories. 


\section{Background on Salmonella and Campylobacter}

\subsection{Salmonella}

\subsubsection{Classification, biology and clinical features}

The taxonomic classification and nomenclature of the Salmonella genus has been subject to a number of rearrangements over the years, as a natural consequence of improved methods for determining the true relatedness of this group of bacteria. Currently the Salmonella genus consists of the two species $S$. enterica and $S$. bongori, two lineages suspected to have diverged early in evolution. S. enterica is further divided into the following six subspecies: $S$. enterica subsp. enterica, S. enterica subsp. salamae, S. enterica subsp. arizonae, S. enterica subsp. diarizonae, S. enterica subsp. houtenae and S. enterica subsp. indica.

Subspecies are seperated into serovars according to the antigenic White-Kauffmann-Le Minor scheme (72), based on somatic (O), flagellar (H) and capsular (Vi) antigens. Today a total of 2579 serovars are recognised, the vast majority (>99.5\%) belonging to the S. enterica species (72). Of these, more than half belong to $S$. enterica subsp. enterica, which are mainly associated with warm-blooded animals, while the remaining subspecies predominantly are found in cold-blooded animals and the environment (171).

Salmonella are Gram-negative facultative anaerobic rods belonging to the Enterobactericeae family. The size of the rods ranges from 0.7-1.5 $\mu \mathrm{m}-2.2-5.0 \mu \mathrm{m}$, producing colonies of approximately 2-4 $\mathrm{mm}$ in diameter. They are non-spore forming, oxidase negative and catalase positive and most members of the genus are motile by petrichous flagella.

Salmonella are known to be quite resilient towards environmental influences, and prolonged persistence in hostile surroundings has been reported $(49,86,169)$. This enhanced survival promotes the transmission of Salmonella from the environment to new hosts (187). The optimal growth temperature for Salmonella is $37^{\circ} \mathrm{C}$, but the temperature range is quite broad $\left(7-45^{\circ} \mathrm{C}\right)$, and preconditioning of cells can result in growth at extreme temperatures at both ends of the scale. Growth of Salmonella in various foods has been observed at $2-4^{\circ} \mathrm{C}$ $(50,62,167)$.

Human Salmonella infection manifests it self as gastroenteritis, enteric (typhoid) fever or in rare cases systemic infections. Typhoid fever is caused by the host restricted serovars $S$. enterica subsp. enterica serovar Typhi and serovar Paratyphi A, B and C, with humans being the main reservoir, and the general route of transmission being faecal-oral. 
Exposure to non-typhoid Salmonella from contaminated foods or from environmental sources can result in infections, depending on a number of factors such as serovar, number of bacteria ingested, vehicle of infection, and microbial environment of the gut. A low infectious dose has been reported for Salmonella, particularly in association with deficiencies in host defences, or if ingested in a vehicle protecting the bacteria from the detrimental effects of the gastric acid (119).

Salmonella infection often presents as an acute gastrointestinal illness. The onset of diarrhoea usually occurs within 6 to 48 hours after ingestion of the contaminated food, but ingestion of a high dose of bacteria can shorten the incubation period to only a few hours. Besides diarrhoea (that may be blood-containing) other common symptoms include abdominal pain or cramps, fever, chills, nausea, vomiting, pain in the joints, headache, myalgia, general malaise and weight loss. In uncomplicated cases, fever usually resolves within 48 to 72 hours, and the average time to recovery is one to two weeks.

\subsubsection{Epidemiology}

Salmonella continues to be an important zoonotic pathogen, affecting the health of both humans and animals on a global scale, thus having wide socioeconomic impact. Salmonella has been estimated to be responsible for 1.3 billion human infections annually. Data from the World Health Organisation (WHO) estimates that typhoid fever accounts for 21.7 million of these (47). Currently, in the US, 40,000 human Salmonella infections are reported annually, however, the true incidence is estimated to 1.4 million a year, resulting in 600 deaths (20), with an estimated cost of 3 billion \$ (21). In the European Union 151,995 confirmed cases of human Salmonella infection were reported to the European Food Safety Agency (EFSA) in 2007 (8).

From 2000 to 2002 a survey of the global distribution of Salmonella serovars proved S. enterica subsp. enterica serovar Enteritidis to be the far most common serovar isolated from humans, accounting for $65 \%$ of all isolates. This tendency was even more pronounced in Europe where $S$. enterica subsp. enterica serovar Enteritidis was associated with $85 \%$ of all human cases (70). The second most frequently isolated serovar from human infections was S. enterica subsp. enterica serovar Typhimurium (12\%) followed by serovar Newport (4\%) (70). The dominance of these serovars could be attributable to their invasive behaviour in important food animals (83). Since the majority of human isolates have similar serovars, efficient source tracing in foodborne Salmonella outbreaks has to rely on further characterisation of isolates. Additional discriminatory typing methods like phage typing, 
antimicrobial susceptibility testing and pulsed-field gel electrophoresis is commonly applied for this purpose.

\subsubsection{Salmonella in the food chain}

The principal habitat of Salmonella is the intestinal tract of warm-blooded animals. The natural excretion into the surrounding environment, where the bacteria are able to persist, explains the ubiquity of Salmonella. The intensive production of food animals in the agricultural industry, and the transmission of Salmonella into this production through contaminated feed and animal supply flocks, wild life reservoirs and the environment, sustains this existence (48).

Commonly Salmonella colonises the intestinal tract of food animals without causing symptoms of illness, and contamination of meat and meat products with intestinal contents during slaughter can and will occur. The establishment of Salmonella, combined with intensive therapeutic and growth promoting use of antimicrobial compounds, in the agricultural industry, has prompted problems with antibiotic resistance. The antibiotics applied in the primary production of food animals, selects for strains that confer resistance towards them, and during subsequent human infection with these strains, options of treatment will exclude these antibiotics. Treatment failure is currently a problem in both developed and developing countries (45).

The majority of human Salmonella infections are contracted through consumption of food of animal origin. Especially meat, poultry, eggs and milk are reported as vehicles of transmission (21). A wide variety of foods are however known to be associated with Salmonella infections, including fresh and dry fruits and vegetables, where contamination can occur during fertilisation, irrigation, harvesting or handling under non-optimal hygiene conditions (82). The transmission of Salmonella is cyclic between humans, animals, food items and environmental sources, and the basic routes are depicted in Figure 1.

Human Salmonella infections are mainly sporadic, however foodborne outbreaks do also occur regularly (21). Foods commonly associated with outbreaks of Salmonella are: Milkbased products (chocolate, cheese, salads, ice cream, etc.), sliced cold meat, vegetables and fruits (48). Pasteurised milk contaminated with $S$. enterica subsp. enterica serovar Typhimurium was responsible for one of the largest outbreaks with 16,284 confirmed cases in the US in 1985 (102), and recently peanut butter and peanut butter containing products contaminated with $S$. enterica subsp. enterica serovar Typhimurium have been responsible 
for 741 human infection in US up to April 2009 (23). In Denmark, an ongoing outbreak with an unidentified source has caused more than 1300 human infections so far with $S$. enterica subsp. enterica serovar Typhimurium (24).

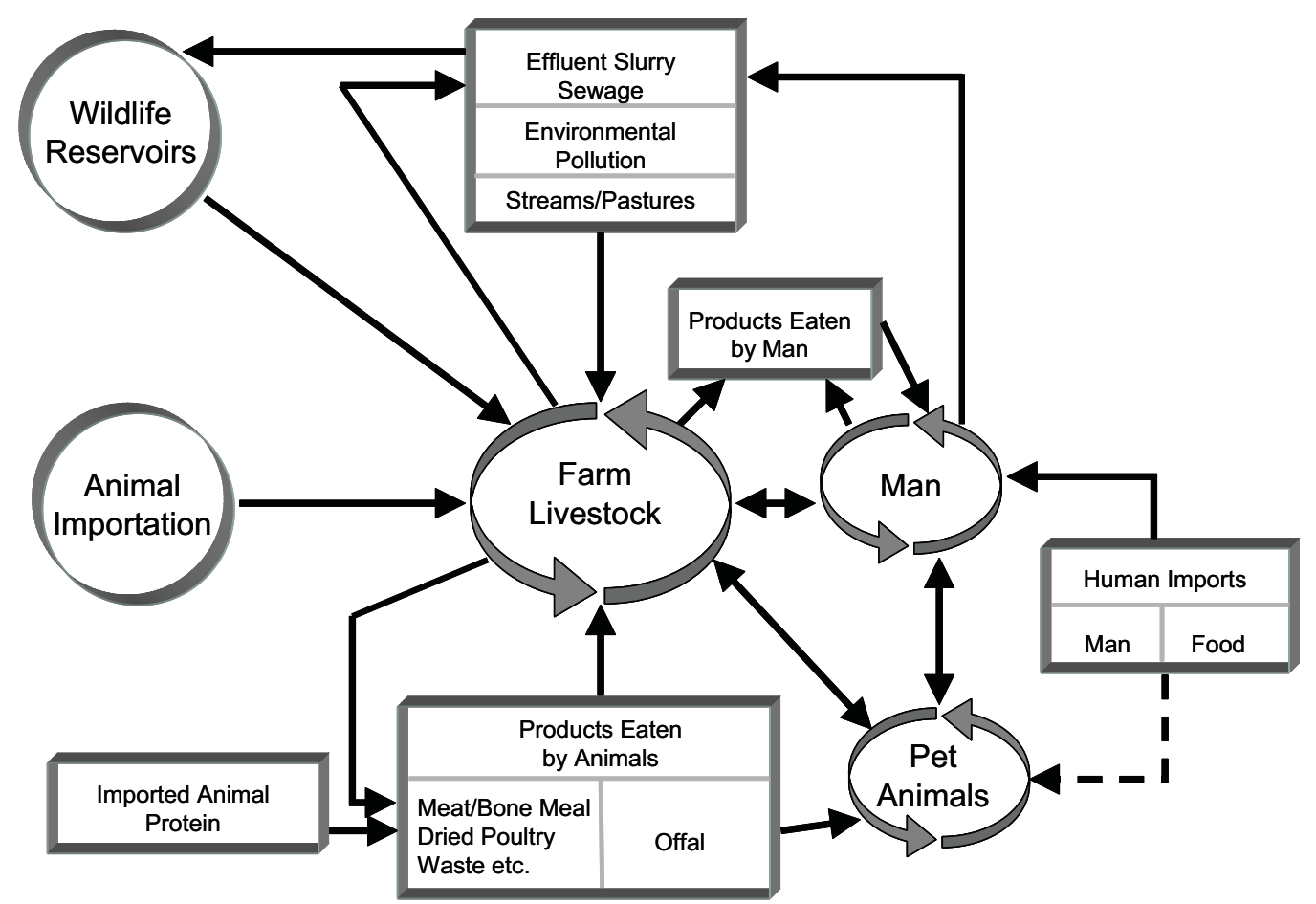

Figure 1. Basic transmission routes of Salmonella. Adapted with permission from Linton (1983) (107).

\subsection{Campylobacter}

\subsubsection{Classification, biology and clinical features}

The genus Campylobacter has undergone profound taxonomic rearrangements over the years. Today it comprises 18 species and 6 subspecies (54). Campylobacter belong to the family Campylobactereraceae, which also includes Arcobacter, Bacteroides ureolyticus and Sulfospirillum (164).

Campylobacter cells are mostly slender, spirally curved rods ranging from $0.2-0.8 \mu \mathrm{m}$ in width and $0.5-5 \mu \mathrm{m}$ in length. They are generally motile with a single polar flagellum at one or both ends giving rise to a very characteristic corkscrew-like motion. They are Gram negative and non-spore forming. Most members of the genus grow under microaerobic conditions, and do not ferment or oxidise carbohydrates, but obtain energy from amino acids or tricarboxylic acid cycle intermediates $(158,176)$. Optimal growth temperature for Campylobacter is $42^{\circ} \mathrm{C}$, and growth does not occur below $30^{\circ} \mathrm{C}$. Heating (decimal reduction time at $55^{\circ} \mathrm{C}$ is $\left.1 \mathrm{~min}\right)$, drying and freezing reduces the number of viable cells substantially 
$(33,137)$. Hence, no proliferation of these bacteria is observed in food items either during processing or storage. Campylobacter differs from other foodborne pathogens in being quite fastidious in their growth requirements, and extremely sensitive towards environmental stress. This pathogen seems to lack adaptive mechanisms, as well as the ability to recognise and respond to various environmental stress influences (138).

Some strains of Campylobacter, as many other microorganisms, are known to enter a viable but non-culturable state (VBNC) to survive for prolonged periods of time in unfavourable environments like water (146). The epidemiological significance of this cell state has been a subject of debate, as some studies have found the VBNC organisms unable to colonise newly hatched chicks $(73,117,193,194)$, while others demonstrate a regained culturability after in vivo passage in mice (29). In a study by Federighi et al. (1998) reversion of VBNC cells to culturable cells was experimentally demonstrated in a mouse model (61), and Klancnik et al., (2009) published a study showing diminished persistence and virulence properties, but retained infectious potential, of the VBNC organisms, in a mouse model (93). Since these findings do not lead to a conclusive determination of the infectious potential of the VBNC state, it is essential that diagnostic methods for foodborne Campylobacter allow for detection and quantification of this state as well (Manuscript IV).

A low infective dose has been reported for $C$. jejuni. Human trials demonstrated that as little as $\mathbf{5 0 0}$ organisms could cause infection. Development of illness was, however, first seen at approx. $10^{4}$ organisms, depending on the immune status of the host, and did not show a clear dose relation (32). Epidemiological observations in humans indicated that the majority of infections were associated with ingestion of a low number of Campylobacter that colonise and multiply inside the host (184).

The symptom of a foodborne Campylobacter infection is usually profuse watery diarrhoea (sometimes blood-containing), accompanied by one or all of the following; nausea, abdominal pain and cramping, malaise, headache and fever $(14,84,125)$. The pathogenesis reflects the virulence of the infecting strain, as well as the susceptibility of the host (138). The illness is usually self limiting with duration of 2-10 days, but severe cases are treated with erythromycin and ciprofloxacin (183). A rare but serious sequelum of Campylobacter infections is Guillain-Barré Syndrome, a neurological paralysis originating from a host immune response towards Campylobacter. The autoimmune response is an effect of bacterial antigenic compounds mimicking the neurological tissue antigens of the host (183). 


\subsubsection{Epidemiology}

Campylobacter has become the leading cause of bacterial gastrointestinal disease in large parts of the developed world. In the European Union, 200,507 confirmed cases of human Campylobacter infections were reported to EFSA in 2007, and for most member states an increased incidence was observed compared to previous years (8). In 2007, 3868 cases of Campylobacter infections were registered in Denmark (9). The frequency of infection, duration of illness and possible sequelae makes Campylobacter a highly important pathogen from a socio-economic perspective. In the US alone, the economic impact due to clinical costs and lost working hours has been estimated to an annual sum of $1.3-6.2$ billion $\$(65)$.

Campylobacter jejuni subsp. jejuni and $C$. coli are by far the most important foodborne human pathogens in the genus, and accounts for more than $95 \%$ of all human clinical isolates world wide (100). However, this figure might be biased, since traditional detection methods favour isolation of these species compared to other potentially pathogenic, but more sensitive Campylobacter species (Manuscript I). The above-mentioned two thermotolerant species including Campylobacter lari, which is also a relevant foodborne species, will albeit be the focus of this thesis, and in the following text the term Campylobacter will refer to them unless otherwise stated.

\subsubsection{Campylobacter in the food chain}

Campylobacters are ubiquitous and are considered commensals of poultry and other avian species, as well as other production and domesticated warm-blooded animals. The basic transmission routes of Campylobacter are shown in Figure 2, and as illustrated the primary route of human infection is suspected to be foodborne. Thus, Campylobacter is considered to be a zoonotic agent transmitted from animals and animal products to humans.

Outbreaks of Campylobacter are rarely seen. Most of the reported cases are sporadic, including only a single family or community member at any one time. The rare foodborne outbreaks related to Campylobacter are predominantly caused by contaminated poultry, milk or drinking water $(8,9)$. In the last five years (2005 to 2009) the largest outbreaks caused by Campylobacter, in Denmark, were waterborne or related to cross-contamination from raw chicken to ready-to-eat food items (9). Even though sources of human infection are rarely identified, case control studies point towards various risk factors: consumption and handling of undercooked or raw poultry (cross-contamination), travelling, contact with 
young domestic animals, unpasteurised milk, swimming in surface waters and consuming barbecued meals $(5,11,14,84,127,162,183)$.

Especially poultry is suspected to be a major source of human infections. This assumption was strengthened during the Belgian dioxin crisis in 1999. All domestically produced poultry and poultry products were withdrawn from the marked due to dioxin contaminated feed, resulting in a $40 \%$ reduction in human Campylobacter infections in the same period of time (178).

In 2007, 27\% of Danish broiler flocks were positive for Campylobacter. The seasonal variation, peaking in July and August, resulted in a prevalence of positive broiler flocks per month ranging from $9 \%$ in April to $56 \%$ in August. This seasonal pattern is reflected in human Campylobacter infections as shown in Figure 3. Regarding chilled Danish broiler meat at retail, 30\% was positive for Campylobacter in 2007 (9). In 2007, EFSA reported an average of $26 \%$ of fresh poultry meat at retail to be positive for Campylobacter. Campylobacter was also commonly detected in live poultry, pigs and cattle (8).

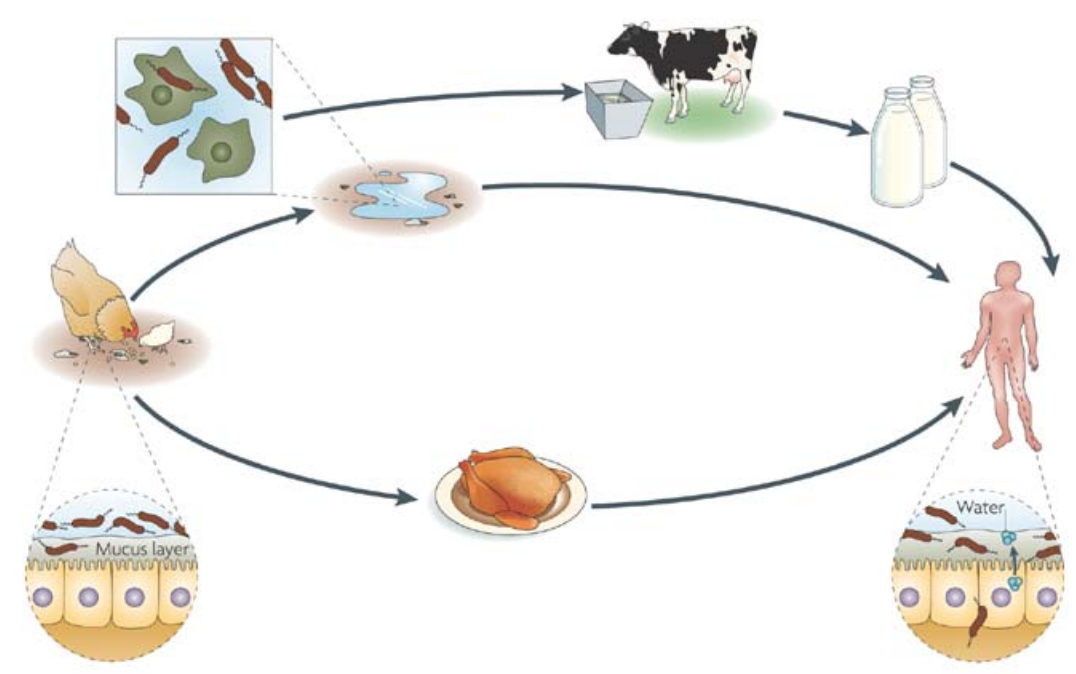

Figure 2. Basic transmission routes of Campylobacter. Reprinted with permission from Young et al., 2007 (192). 


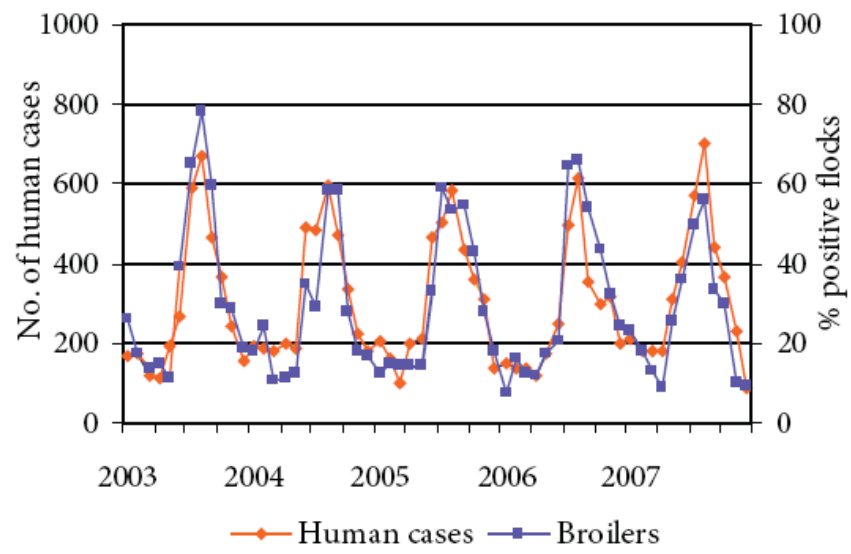

Figure 3. Monthly prevalence of Campylobacter-positive broiler flocks and number of human Campylobacter infections in Denmark from 2003 to 2008 (9). 


\section{Culture-based detection}

\subsection{Salmonella}

The detection and isolation procedures for Salmonella are in principal similar in the various standard methods recommended by the US Food and Drug Administration's (FDA's) Bacteriological Analytical Manual (BAM), Association of Official Analytical Chemists International (AOACl), Nordic Committee on Food Analysis (NMKL) as well as the International Organisation for Standardisation (ISO), however, the media used in the different steps differ $(7,16,18,173)$. In the present thesis, the Nordic NMKL standard culture method (No. 71) was used as a reference method (Manuscript $\mathrm{V}$ and VI, Figure 4).

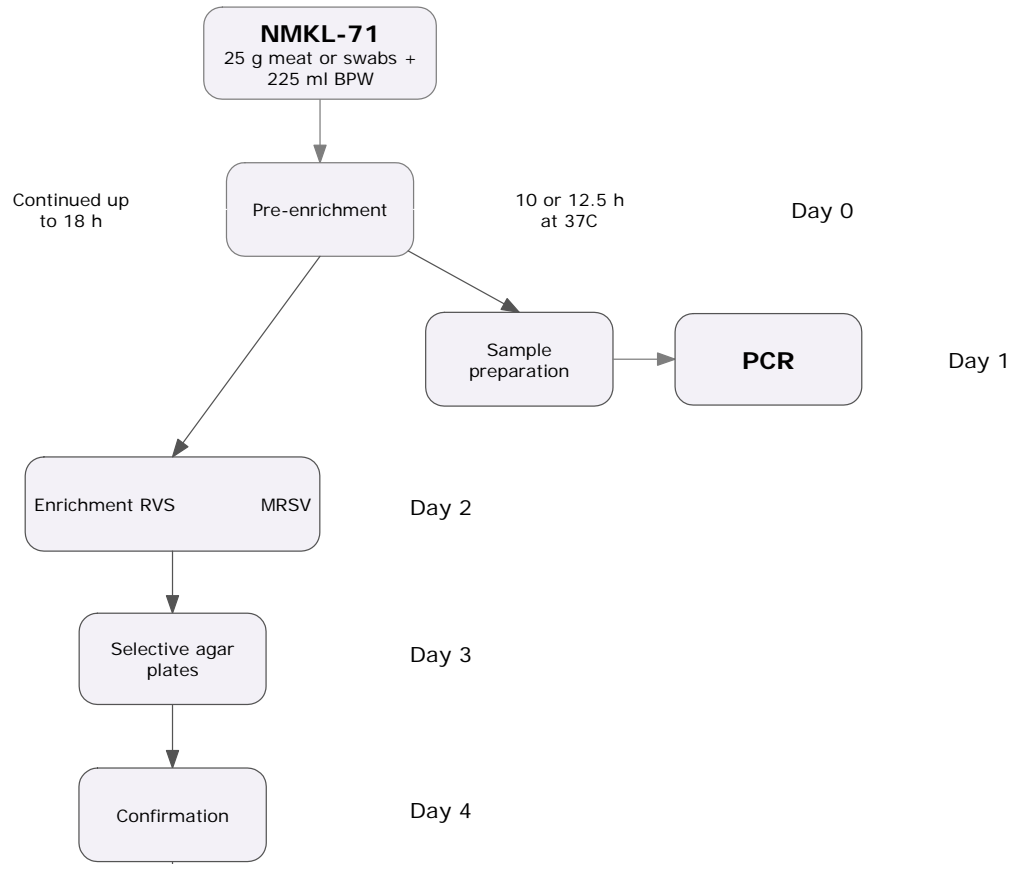

Figure 4. The NMKL-71 and PCR procedures for detection of Salmonella applied in Manuscript VI.

Food, animal feed and environmental samples usually contain low numbers of potentially stressed Salmonella bacteria and therefore an enrichment procedure is needed. The conventional routine analysis methods for isolating Salmonella rely on four steps, the first being pre-enrichment in non-selective media to aid the recovery of sublethally injured Salmonella (64). Even though Salmonella is viable and able to cause disease under the right conditions, the organisms can easily be killed if they are grown under selective pressure, such as high temperature or in the presence of chemical additives (180). It has however been suggested that pre-enrichment in non-selective enrichment media can mask the presence of Salmonella by allowing growth of competing microflora (168). 
Buffered peptone water (BPW) is recommended for pre-enrichment in most standard methods, and it was also shown to be slightly superior to brain heart infusion broth and tryptone soya broth in supporting the resuscitation and growth of Salmonella after 6 and 8 hours of pre-enrichment in the present thesis (Manuscript V). Addition of growth-promoting or selective reagent directly to the BPW was also attempted, but this did not provide Salmonella with a competitive edge (Manuscript V). Based on the results obtained in this study it was speculated that a delayed addition of selective reagents to the BPW could be an alternative, in order to allow an initial recovery of stressed and injured Salmonella cells. Even though slightly improved real-time PCR results were obtained by addition of novobiocin (20 and $50 \mathrm{mg} / \mathrm{L})$ and brilliant green $(10 \mathrm{mg} / \mathrm{L})$ to the BPW, the advantages of this was not sufficient to apply them, and thereby deviate from the enrichment procedure of the standard method, making retrospective culture-confirmation of PCR-results difficult (Manuscript V). Addition of malachite green has been reported to have both inhibitory and promotive effects on the growth of Salmonella in other studies $(34,88)$, and brilliant green has also been found to be inhibitory (34). Novobiocin addition has been reported to increase the recovery of Salmonella from faecal samples (87).

The second step is enrichment in selective media to increase the levels of Salmonella, thus enabling detection on selective agar plates. This is accomplished by inhibiting the growth of accompanying microflora by the addition of different selective agents in the media. The most commonly used media for selective enrichment are Rappaport-Vassiliades soy broth, selenite cysteine broth and tetrathionate broth. Modified semisolid Rappaport-Vassiliades is another selective media particularly useful for detecting salmonellae in feces and environmental samples (52). It is based on the ability of salmonellae to migrate through the selective medium ahead of competing motile organisms, thus producing opaque halos of growth.

Third step in the analysis method is isolation on selective agar plates by streaking out the selective enrichment broths on selective solid media to obtain isolated colonies. The growth of other bacteria is selectively repressed by the addition of inhibitory compounds and salmonellae are differentiated from other bacteria e.g. by the production of $\mathrm{H}_{2} \mathrm{~S}$ or acid from sugar. It is recommended that at least two different media be employed, since different serotypes can have varying sensitivity towards the different selective agents applied in the agar (157). Commonly employed media include brilliant green, xylose lysine Tergitol-4, bismuth sulphide, Hektoen enteric, xylose lysine deoxycholate and Rambach agars. Recently, several chromogenic agars have been compared favourably to these, being more sensitive and specific than the common agars $(40,57,68,111,141,174)$. Adding to the advantages of 
the chromogenic agar is that the need for subsequent confirmation of isolates by subculture and biochemical test is reduced, since identification from the primary medium is possible.

Finally, confirmation of presumptive Salmonella isolates is performed by biochemical tests and serotyping. Presumptive colonies are inoculated on non-selective plates in order to obtain isolated colonies that can be characterised. Several biochemical tests are then employed, i.e. triple sugar iron agar, mannitol, urea, ornithin decarboxylase and lysine decarboxylase (18). A serological verification is performed by determining the antigenic composition. The antigens are classified as somatic $(\mathrm{O})$ and flagellar $(\mathrm{H})$ and are detected by an agglutination test using polyvalent antisera.

Human gastroenteritis caused by Salmonella is diagnosed by culturing fecal samples. Normally, isolation is accomplished by direct plating on selective plates from fecal samples containing high numbers of target bacteria (71). An enrichment step in selenite broth has been reported to increase the sensitivity of the culture method, but this has to be weight against the additional $24 \mathrm{~h}$ needed, until a diagnostic answer can be given.

\subsection{Campylobacter}

Detection and isolation procedures for Campylobacter differ slightly more than for Salmonella regarding the media, selective agents and incubation temperatures applied in the various standard methods from ISO, BAM and NMKL. However, the main principles of the standard methods are similar, and imply direct spreading onto selective agar plates of samples with a presumed high number of Campylobacter (fecal), and enrichment prior to selective isolation of samples a) presumed to harbour low numbers of Campylobacter, or b) samples containing a relatively large fraction of cells injured due to processing or unfavourable environmental conditions $(12,13,85)$.

For food samples and other samples where a low number/injured Campylobacter cells are suspected to be present in a highly mixed background flora, an enrichment step is necessary prior to isolation on selective agar plates. For fecal samples drawn after the acute stage of the infection an enrichment step can likewise be necessary. Some of the most frequently employed enrichment broth media for Campylobacter are Bolton, Preston, Park-Sanders and Exeter. Since Campylobacter is sensitive towards peroxides, radical scavengers like horse/sheep blood and charcoal are often included in these enrichment broths, as well as growth promoting reagents like ferrous sulphate, sodium metabisulphite and sodium pyruvate (FBP). Enrichment broths operate with various selective systems to reduce growth 
of accompanying flora and combinations of cefoperazone, vancomycin, polymyxin B, amphotericin $B$, colistin, trimethoprim and rifampicin are employed. Furthermore, culturing is performed at approx. $42^{\circ} \mathrm{C}$ in a microaerobic atmosphere $\left(5 \% \mathrm{O}_{2}, 10 \% \mathrm{CO}_{2}, 85 \% \mathrm{~N}_{2}\right)$, adding to the selectivity $(12,13,85)$.

Most media (broth and agar) for Campylobacter have been designed to support growth of $C$. jejuni and C. coli. As the genus comprises several potentially pathogenic species that are susceptible to the above-mentioned antibiotics, like $C$. upsaliensis, C. lari, C. hyointestinalis and $C$. mucosalis, this might lead to a misdiagnosis and underestimation of the burden of infection (120). Growth of $C$. coli has been shown to be inhibited by the selective agents included in Preston broth - but not in Bolton broth (Manuscript I). In contrast to these findings, Preston and Bolton broth supported the growth of thermotolerant Campylobacter from boot and cloacae swabs and chicken neck skin equally well (Manuscript IV). Other studies performed on the subject produced controversial results as well, probably due to differences in sample matrix, dominant Campylobacter species, and accompanying microflora. Bolton broth is currently recommended for enrichment in both the NMKL 119 and ISO 10272-1 standards, and it was also proven to be superior to Preston and MuellerHinton broth in supporting the growth of a test panel of Campylobacter strains of relevance to food safety (Manuscript I). For these reasons Bolton broth was chosen for enrichment of Campylobacter prior to PCR detection in Manuscript I. Applying filter techniques, like the Cape Town protocol, instead of selective antibiotics, is known to result in a significantly higher yield of species other than $C$. jejuni and C. coli (101). Some protocols e.g. BAM and Park-Sanders, recommend delayed addition of selective agents and/or a reduced initial incubation temperature to promote the recovery of injured cells and possibly also the growth of more sensitive species.

Following enrichment, or directly from samples with presumed high numbers of Campylobacter, the samples are spread on selective agar plates. Again a high number of solid media exist for Campylobacter, and modifications to existing selective agars are numerous as well. Some of the most common ones are: modified charcoal cefoperazone deoxycholate (mCCDA), Skirrow, Karmali, Preston, Abeyta-Hunt-Bark (AHB), Campy-cefex and Butzler. It is recommended to use two selective agars with different selective principles in parallel to increase the yield, but currently ISO 10272-1 is the only standard culture method prescribing this (12). Solid media for enumeration of Campylobacter should always be dried to avoid excessive moist and thereby obtain single colonies. 
Identification of Campylobacter presumptive colonies is performed by subculturing five colonies from selective media onto non-selective media. These are examined microscopically regarding morphology and motility. Furthermore, a number of tests can be performed to confirm the identification and determine the species; growth at 25,37 and $42^{\circ} \mathrm{C}$, catalase, oxidase, glucose utilisation, hippurate hydrolysis etc. Besides the fact that Campylobacter are relatively biochemically inactive, former studies of their biochemical properties also reveal inconsistencies. In addition to this, biochemical identification can be encumbered with uncertainties derived from experimental variation, subjectivity of tests, anomalous properties of the single isolate and inconsistencies related to age and conditions of culture.

\subsection{Limitations of culture-based detection}

In summary, conventional culture methods for detection of Salmonella and Campylobacter are time-consuming and labour-intensive. A final positive test result can take up to 8 days. Furthermore, these methods are generally believed to suffer from poor specificity due to difficulties in recovering sublethally injured cells, problems in the identification of atypical colonies and a high degree of false-positive results. From a food safety point of view, these culture-based methods fail the purpose of producing a rapid and reliable result, which can be used pre-retail to ensure the microbiological safety of the products being released to the consumer. An important advantage of conventional culture methods is nevertheless that they produce an isolate that can be characterised further. 


\section{Detection by PCR}

Since Salmonella and Campylobacter worldwide remain sources of human infection, causing serious illness and socioeconomic problems, a lot of effort has been devoted to the development and improvement of detection methods in clinical, environmental and especially food samples. PCR has been shown to be a valuable and advantageous alternative to culture-based detection regarding speed, limit of detection, selectivity, sensitivity and potential for automation (173).

\subsection{The principle of PCR}

PCR is the most widely used nucleic acid based technique today. In PCR repeated cycles of DNA synthesis is applied in order to replicate a target DNA sequence. In a few hours PCR amplification can produce millions of copies of a target DNA - in theory from a single copy thus enabling the detection of DNA present initially in very low amounts (142). PCR is performed in a thermal cycling instrument and consists of three temperature steps, the first being heat-denaturation of the double stranded DNA performed at around $95^{\circ} \mathrm{C}$. Following this, the temperature is lowered to $40-60^{\circ} \mathrm{C}$, allowing the primers (short stretches of nucleotides designed to match the DNA target sequence) to anneal to the complementary nucleotides of the DNA target sequence. After the primers have annealed to the DNA target, the DNA polymerase enzyme initiates the extension of the primers by adding one appropriate nucleotide after another, creating a DNA strand complementary to the DNA target sequence (Figure 5). Extension usually takes place at $72^{\circ} \mathrm{C}$ to ensure optimal performance of the DNA polymerase enzyme. This three-stage cycle (denaturation, annealing and extension) is repeated 30-50 times in the thermal cycler, with the newly synthesised DNA strands acting as templates for the synthesis of new complementary DNA sequences. The rate of formation of target DNA sequences is thus exponential, and as a result the amount of target DNA is doubled in each three-staged temperature cycle. Conventional PCR employs end-point detection, where the PCR product i.e. the amplified DNA target sequence, is visualised by gel electrophoresis. The PCR products are loaded onto an agarose gel together with an appropriate molecular marker, eletrophoresis is performed and the gel is stained with ethidium bromide, and visualised by ultraviolet transillumination $(59,123,142,165)$. This technique was employed in Manuscript I and II. 

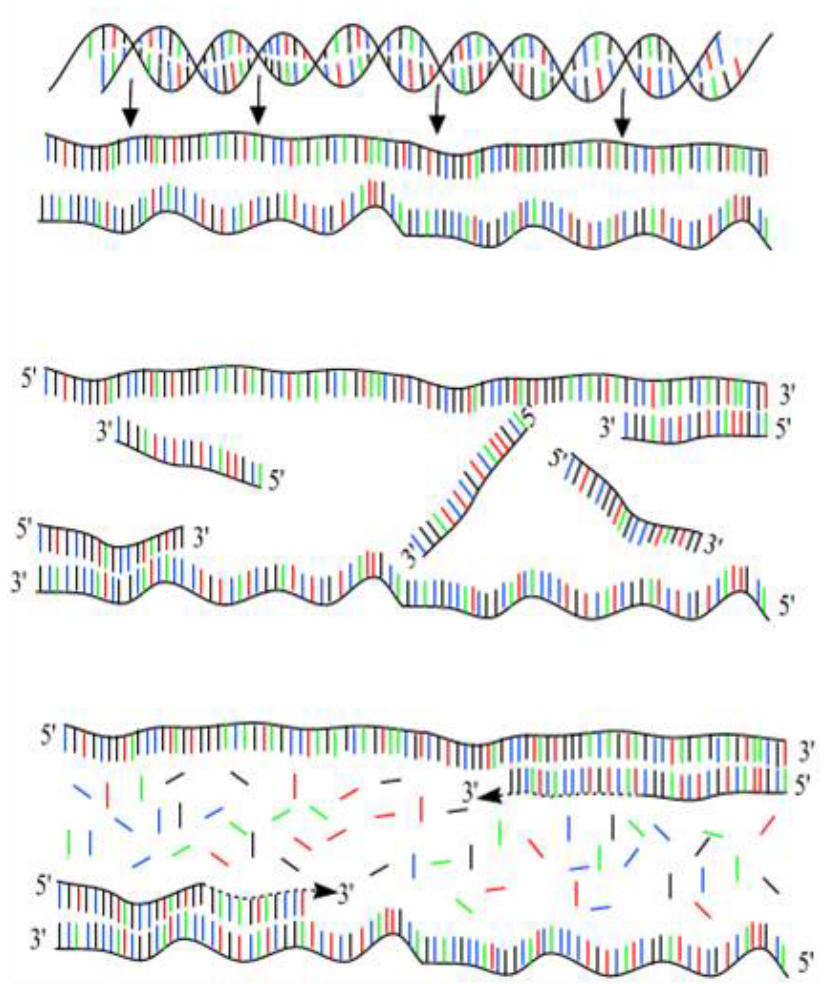

1) Denaturation: Separation of the double stranded DNA helix by heat.

2) Annealing of the primers to complementary sites on the target DNA.

3) Extension of the primers by the DNA polymerase enzyme.

Figure 5. The principle of PCR showing the DNA denaturation and replication in the different temperature steps applied (25).

In real-time PCR the amplification can be monitored by incorporation of a fluorescently labelled probe or a DNA binding dye like SYBR green. A variety of probe types exist employing different principles (Manuscript VII), but all producing a change in fluorescence upon PCR product accumulation. This fluorescent signal is recorded after each temperature cycle, and the accumulation of PCR product thereby visualised. Real-time PCR is more sensitive than conventional PCR and it holds the possibility of quantification. Additional advantages compared to conventional PCR include: a reduced risk of cross-contamination from exposing the environment to the PCR products, a reduction in hands-on and total time of analysis and finally the possibility of a higher degree of automation $(97,110,172)$. Realtime PCR techniques were applied in Manuscript III-VIII.

\subsection{PCR inhibition}

One of the drawbacks of applying PCR for detection of DNA is the sensitive nature of the method and the reagents which make it prone to inhibition. Inhibition can be exerted at several levels in PCR: 1) the availability of the DNA can be reduced due to inhibition of cell 
lysis, 2) the DNA can be degraded or captured by inhibitors, and 3) the activity of the DNA polymerase enzyme can be reduced by inhibitors (186). Of these, the inhibition of the activity of DNA polymerase seems to be the most significant. This is also reflected in the fact, that inhibition in some cases can be overcome by simply replacing the DNA polymerase with one that exhibits more resistance towards the particular inhibitors $(1,95,108)$. The Tth DNA polymerase, which has been applied throughout the present thesis (Manuscript I-VIII), has been shown to be resistant towards inhibition in a range of sample matrices $(1,92,108$, 109).

Several compounds, that can be found in samples, enrichment media and DNA extraction reagents, are known to inhibit PCR amplification e.g. lipids, proteins, blood, urea, ferric ammonium citrate, bile salts, esculin, acriflavin, magnesium chloride, detergents, lysozyme, $\mathrm{NaOH}$, alcohols etc. $(149,186)$, (Manuscript I). Even though most of the inhibitory effects from sample and media constituents can be overcome by extracting the DNA from the sample prior to PCR amplification, it is an absolute prerequisite to include an internal amplification control (IAC) in PCR to avoid false-negative results due to technical problems with reagents or thermal cycler, or as a result of PCR inhibition (81). Without an IAC present in every single PCR well, a negative result should not be regarded as being true (78). Competitive IAC's are frequently applied, and the advantage of this approach is that multiplexing is avoided, as the IAC is amplified with the same primers as the target DNA. Using the competitive approach, it is critical that the concentration of the IAC is close to the limit of detection, in order not to extinguish the signal from the target DNA and to reveal even a slight inhibition of the PCR. Competitive IAC's are often designed larger in size than the target, to drive the reaction kinetics towards the target $(39,80)$. The IAC's for both the Salmonella and the Campylobacter real-time PCR were designed after this competitive strategy (Manuscript I-VIII).

Furthermore, it is important to include well-defined and appropriate test controls both during the development and validation, but also during implementation and use of a diagnostic PCR method. These include positive and negative processing controls to reveal errors in the different processing steps of the method (143). Finally, reagent control (nontemplate control, NTC), and positive and negative DNA controls should be included in each PCR run to verify that no PCR reagents are contaminated, and that the PCR responses are as expected. 


\subsection{Sample preparation}

The differences in sample matrices, enrichment media and PCR targets demand careful consideration and optimisation of sample preparation in each single method. For this reason numerous sample preparation methods for PCR analysis have been published. No attempt to describe differences, advantages and limitations of various sample preparation methods will be attempted in this thesis (For a review see Rådström et al., 2004 (143)). Reducing the often large initial sample volume to a small homogeneous volume of purified DNA/RNA to be amplified in PCR is a challenge that has not yet been overcome. In most PCR methods DNA is extracted from a subset of the sample (usually $<5 \mathrm{ml}$ ) to avoid the inhibitory effects of other sample constituents, and typically 1-10 $\mu \mathrm{l}$ of this is added as template in the PCR. In the present thesis a simple resin-based extraction method (179) was found to overcome the inhibition from enrichment media and sample constituents in Manuscript I. This resin-based extraction method was applied both in the collaborative validation (Manuscript II), and in the development of the real-time PCR method (Manuscript III). Preliminary experiments conducted prior to the work described in Manuscript $V$, included a comparison study of several commercial manual DNA extraction kits, and several kits for the automated DNA extraction platform KingFisher (Thermo Labsystems, Helsinki, Finland). Applying the Magnesil KF, Genomic System (Promega Corporation, Madison, WI, USA) on the KingFisher platform for DNA extraction, was shown to be equal or superior to the other methods (data not shown). Other studies have shown the DNA recovery applying various extraction techniques to be strongly sample dependent $(63,155,132)$. Since the methods developed and validated in Manuscripts III-VI were meant for use in routine laboratories with a high throughput and the need for a high degree of quality control, this automated DNA extraction procedure was applied throughout the remaining of this thesis.

The loss of DNA during extraction on the KingFisher platform was evaluated in Manuscript V, by comparing the results obtained in the real-time PCR method on samples containing a known amount of reference DNA, before and after DNA extraction. The experiment was designed in a way that theoretically equivalent amounts of DNA was analysed in PCR. The DNA loss was shown to be quite high (in average, results around 5 threshold cycle values higher were obtained post DNA extraction), especially in samples containing high levels of DNA, perhaps indicating a limitation in the binding capacity of the paramagnetic beads applied in the procedure. Increasing the amount of paramagnetic particles did however only lower the threshold cycle values slightly. 


\subsection{Strategies for optimisation of real-time PCR-based methods}

Optimisation of sample preparation (Manuscript V), PCR master mix (Manuscript V), and using alternative probe chemistries (Manuscript VII) can be applied to optimise the overall performance of real-time PCR. The strategies described in the following sections are not unique to detection of Salmonella and Campylobacter, but could be applied to improve the sensitivity and optimise the performance of other real-time PCR-based methods as well.

The Salmonella method consists of three steps: Pre-enrichment, DNA extraction and realtime PCR analysis. In order to shorten the total time of analysis as much as possible, it was attempted to optimise all steps of the method (Manuscript V).

\subsubsection{Optimisation of sample preparation}

A reduction of the time of pre-enrichment, necessary for detection in real-time PCR, was attempted by evaluating the growth supporting capacity of different media. The effect of adding growth-promoting and background flora-reducing agents was investigated on a panel of Salmonella serovars of importance to meat. In accordance with the findings of other studies $(66,79,175)$, no alternative media was identified as being significantly superior to BPW. The choice of BPW, which is recommended for pre-enrichment in both the ISO and the NMKL standard, also makes retrospective culture-confirmation of positive PCR results possible (Manuscript V).

Extraction of DNA from pre-enrichment volumes of 1, 2, 5 and $10 \mathrm{ml}$ was performed (Manuscript V). Five $\mathrm{ml}$ was shown to improve the detection limit and produce steeper amplification curves. Even though it would be advantageous to operate with larger volumes, the available technology does not enable separation of the target from inhibitors and copurified DNA from background flora, reducing the sensitivity of PCR (181).

The DNA extraction on KF is based on the binding of DNA to silica-coated paramagnetic beads under high concentrations of chaotropic salts, and the release of the collected DNA in a low-ionic strength buffer. Attempts to optimise the DNA extraction procedure was made by combining the different binding, washing and elution steps of the KF in various ways. The amount of paramagnetic beads was increased, which improved the PCR results, and the elution volume was decreased which gave poor and inconsistent PCR results (Manuscript V). 


\subsubsection{Optimisation of PCR master mix and probe chemistry}

Optimisation of the PCR assay was performed by titration of the single components in the master mix, as well as the addition of the PCR adjuvants glycerol and DMSO to enhance the specificity and reduce formation of secondary structures (177). The thermal profile of the PCR assay was likewise optimised (Manuscript V).

The template volume for PCR was increased from 5 to 10 and $20 \mu \mathrm{l}$ with lower threshold cycle values, steeper amplification curves and a higher reproducibility as a consequence (Manuscript V). However, this is not always the case as shown in Manuscript VIII and by Botteldoorn et al., 2008, where a clear PCR inhibition was observed when increasing the amount of template DNA in the PCR (35).

In Manuscript VII it was shown that optimising the probe chemistry can be a convenient way to improve the sensitivity of a real-time PCR assay. The performance of the three probe chemistries: locked nucleic acid (LNA) (36), minor groove binder (MGB) (3) and Scorpion (uni- and bi-molecular) (185) were compared to a conventional TaqMan probe.

A real-time PCR probe should be designed to obtain a melting temperature around $5-10^{\circ} \mathrm{C}$ higher than the corresponding primers, in order to ensure correct cleavage of the probe element during extension. For conventional TaqMan probes, this often results in 25-30 nucleotides long probes, which can be difficult to design in case of a short specific region.

Claimed advantages of the short probe types like LNA and MGB are improved sensitivity towards single-nucleotide mismatches, and improved signal-to-noise ratio due to reduced spurious annealing and a reduced distance between the reporter fluorophore and the quencher (98).

While conventional TaqMan, LNA and MGB probes are hydrolysis probes, with the reporting fluorophore $(R)$ separated from the quencher $(Q)$ by the $5^{\prime}-3^{\prime}$-exonuclease activity of the DNA polymerase during the amplification process (Figure 6), the Scorpion system relies on an unique intra-molecular probing mechanism as shown in Figure 7. Theoretically, the Scorpion chemistry should be more sensitive than the other probes evaluated in Manuscript VII, due to this intra molecular probing mechanism. In addition the quenching mechanism is collisional rather than relying on through-space quenching like TaqMan, LNA and MGB probes $(161,166)$. The Scorpion chemistry was, however, not compatible with the real-time PCR assay in the present thesis (Manuscript VII). 

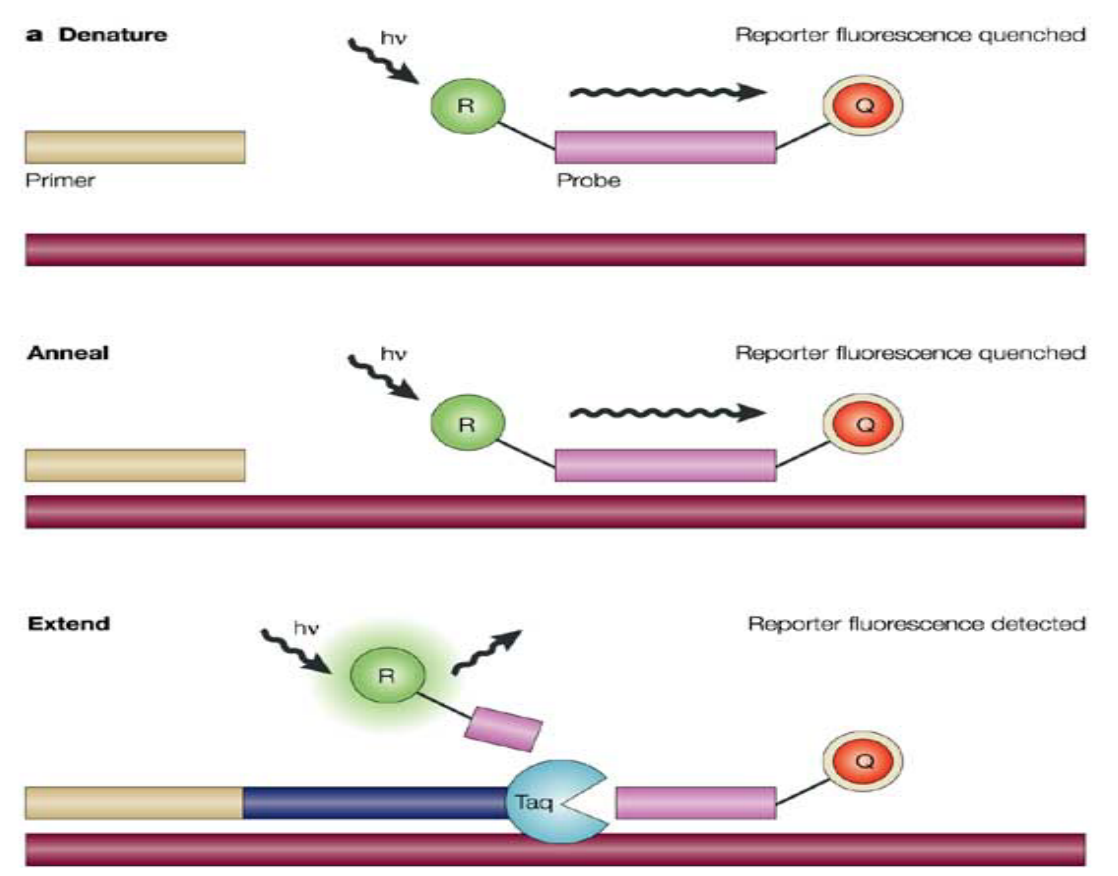

Figure 6. Principle of a hydrolysis probe. The probe is labelled with a reporting fluorophore $(R)$ in one end and a quencher $(Q)$ in the other. The proximity of the quencher to the reporter while the probe is intact, suppresses the signal from the reporter. Upon extension of the primer by the DNA polymerase, the probe is hydrolysed, the reporter separated from the quencher, and the fluorescence detected. Reprinted with permission from Koch (2004) (96).

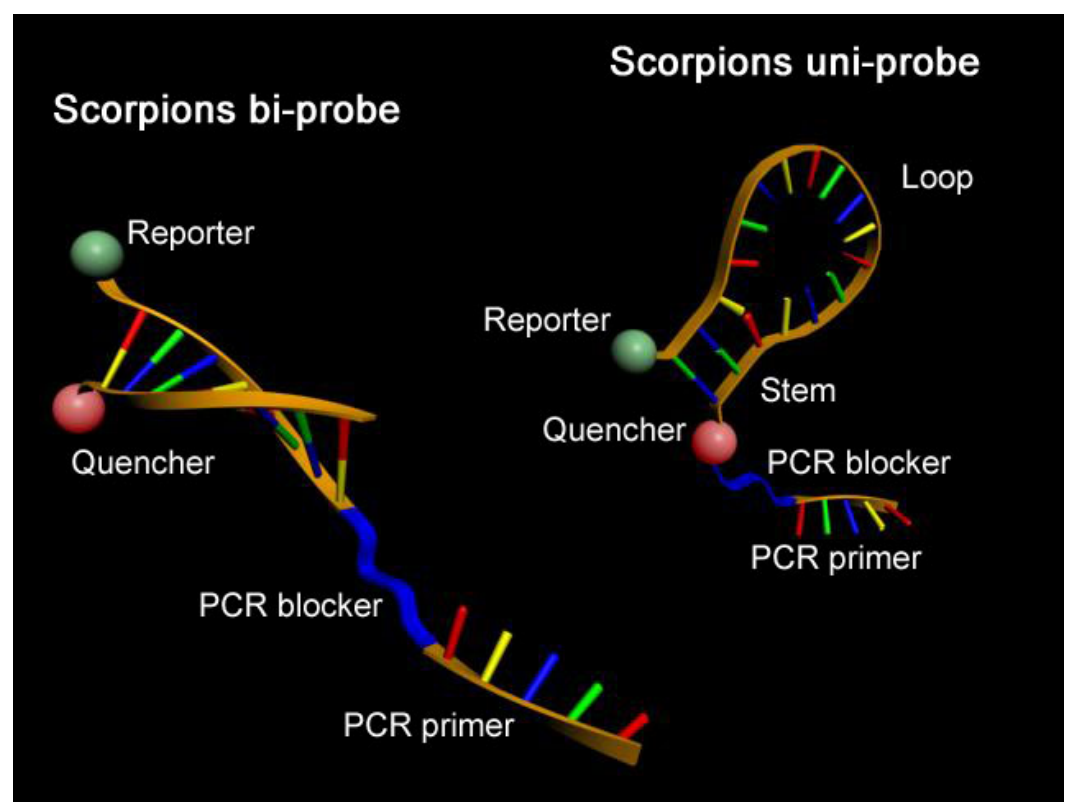

Figure 7. The structure of uni- and bi-molecular Scorpion probes. The uni-molecular system consists of a probe element, inserted in a molecular beacon configuration, labelled at the ends with a quencher and a fluorophore, respectively. The tail is linked to the $5^{\prime}$-end of a primer via a PCR-blocker. Upon annealing and extension of the primer a complementary probe site is created. Following the next denaturation cycle, the probe element will fold up and anneal to this, rather than entering the hairpin loop conformation again, because it is kinetically favourable. The reporter is thus separated from the quencher, and fluorescence can be detected. The bimolecular system operates after the same principle, only the hairpin loop configuration is replaced by two probes, one labelled with a reporter and one with a quencher. The bi-molecular system is an improvement of the technology, and should give rise to an increased fluorescent signal, since the distance between the reporter and the quencher is increased compared to the uni-molecular type where they remain on the same DNA-strand $(19,26,185)$. Reprinted from (26). 
The results obtained in this comparative study proved the LNA probe to be the most sensitive probe chemistry, producing the lowest threshold cycle values and the highest amplification efficiency. Inconsistent results have been obtained in other studies comparing some of the same probe chemistries $(46,105,145)$, emphasising the need to individually evaluate the optimal probe chemistry for a given PCR assay, as the conclusion drawn from one comparison study not necessarily is generally applicable.

\subsection{Validation for routine diagnosis}

Despite the abundance of PCR methods for detection of foodborne pathogens, a lack of proper method validation has hampered the dissemination and implementation of PCR in diagnostic routine laboratories $(78,115)$.

The sensitive nature of the PCR technique can be an impediment for implementation, as the performance of a PCR method can vary significantly depending on the sample matrix, sample preparation (Manuscript I), PCR reagents $(38,189)$, thermal cycler (145) (Manuscript III) and personnel. The results of a PCR method developed in one laboratory can be very difficult to reproduce in another. A diagnostic PCR method, to be used as a tool to ensure food safety and public health, has to be reliable and consistent, day after day, in the hands of different personnel, on different sample matrices and different thermal cyclers. For these reasons, validation following an integrated approach including sample matrix, sampling, sample treatment and PCR is necessary.

The basic objective of validating a PCR-based method for foodborne pathogens is to demonstrate that it can produce results that are comparable or superior to the current standard method. Several validation organisations like ISO, Deutsches Institute für Normung (DIN), Association Française de Normalisation (AFNOR) and NordVal have issued protocols and guidelines for the validation of alternative microbiological methods. In the present thesis, the real-time PCR-based methods for detection of Salmonella and Campylobacter were validated according to the NordVal protocol, and subsequently approved (Manuscript IV and VI), $(27,28)$. The overall flow of the validation procedure for both of the real-time PCR-based methods, showing the contents and results of the comparative in-house study and the collaborative trial is shown in Figure 8. 
The Salmonella method has been implemented for screening of samples at major Danish slaughterhouses, reducing the post-slaughter storage time and facilitating the fast release and export of Salmonella-free fresh meat (Manuscript VI). The Campylobacter method was implemented at one of the large Danish poultry slaughterhouses, and used for logistic slaughter planning, as well as for production of certified Campylobacter-free chickens (Manuscript IV).

Retrospectively, the collaborative trials performed in this study have limitations. The first trial conducted, to validate the conventional PCR method for Campylobacter, lacked the appropriate controls to reveal possible cross-contamination in the participating laboratories. The ring-trial performed on Salmonella real-time PCR was restricted to one brand of thermal cyclers, on which the method had also been developed and optimised. It was later shown that the reproducibility of the method using other thermal cyclers was poor (data not shown). The comprehensive optimisation of the method using only this brand of thermal cycler, to achieve a lower limit of detection, and thereby being able to shorten the preenrichment time as much as possible, resulted in a loss of robustness. Finally, the preenrichment step of the method was not performed by the ring-trial participants, but at the organising laboratory. This had been approved by NordVal in advance, and the approach was chosen to minimize variations not attributable to the molecular based detection step. Future studies need to take these experiences into consideration, and adjust their procedures accorcingly.

\subsection{PCR detection of Salmonella}

Numerous PCR assays detecting Salmonella in a variety of sample matrices have been described in the literature. The majority of them deal with detection in food, reflecting the epidemiology of this human pathogen. The PCR-based detection methods in food commonly employ a pre-enrichment step combined with subsequent PCR detection. The preenrichment times reported vary from 6 to 24 hours, depending on the artificial inoculation level of Salmonella in the experimental design of the studies (Manuscript V), $(4,58,60,74$, $114,124)$. Studies taking the limit of detection of $1 \mathrm{CFU} / 25 \mathrm{~g}$ in food samples into consideration, report a minimum of pre-enrichment of 8-10 hours, as in the present thesis (Manuscript $\mathrm{V}$ and $\mathrm{VI}),(43,67,74)$. Several of these PCR assays amplify a part of the invA gene, encoding a protein involved in the invasion of epithelial cells, however, it has been shown that invA is lacking in some strains $(69,144)$. 


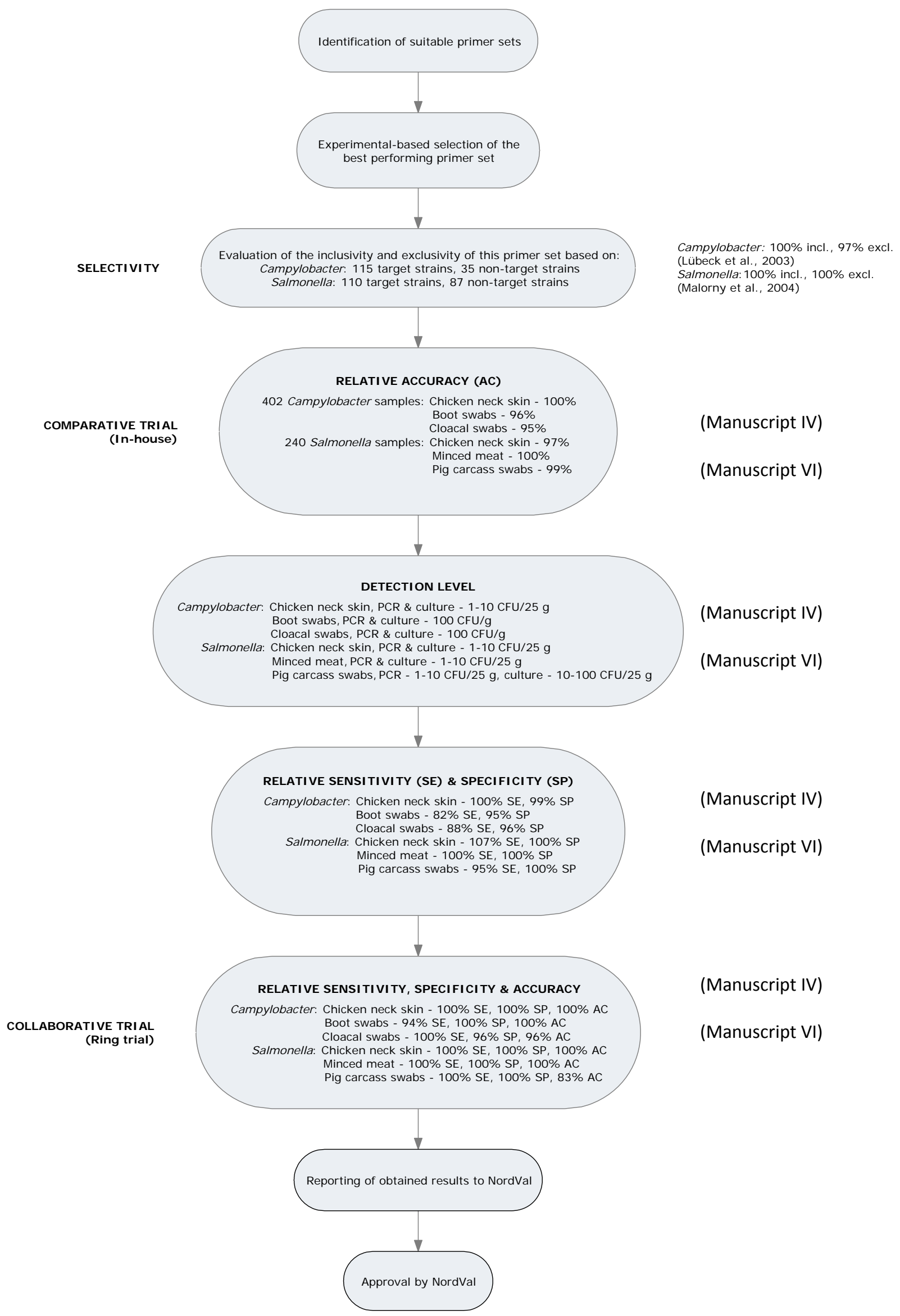

Figure 8. The general steps of the validation procedure (10). 
Malorny et al. (2004) recently designed a PCR assay for amplification of a part of the ttrRSBCA locus encoding proteins used for tetrathionate respiration (114). The inclusivity and exclusivity of this assay was tested applying 110 Salmonella strains and 87 non-Salmonella strains, and was found to be $100 \%$ in both cases. The assay has furthermore been validated in collaborative trials and found to perform satisfactory (116). This PCR assay forms the basis for the Salmonella detection method developed and validated in Manuscript $\mathrm{V}$ and $\mathrm{VI}$. Following substantial optimisations (Manuscript V), the final real-time PCR-based method was able to detect Salmonella in minced meat and chicken skin samples after $12 \pm 2$ hours of enrichment and in pig carcass swab samples after $14 \pm 1.5$ hours of enrichment (Manuscript $\mathrm{VI}$ ), compared to at least 3 days for culture-based detection (18). The analysis time of this non-commercial, open-formula PCR-based method is comparable with the fastest validated DNA-based analysis kit (Bio-Rad, GeneSystems) for meat samples, and 1-3 hours shorter for pig carcass swab samples.

PCR detection methods have also been described for human clinical samples. A number of them are designed to target specific serovars and have little use as diagnostic screening tools, but more broad methods for Salmonella enterica have compared favourably to conventional culture-based methods in several studies $(6,156)$.

Commercial systems based on the PCR detection principle are available for Salmonella (TaqMan ${ }^{\circledR}$ Salmonella kit from Applied Biosystems, iQ-Check ${ }^{\mathrm{TM}}$ Salmonella kit from Bio-Rad). One of the most widely used is the $B A X^{\circledR}$ (DuPont Qualicon, Wilmington, Delaware), an integrated system where pre-enrichment of 22-26 hours, followed by 3 hours of regrowth depending on the sample matrix, is followed by DNA extraction and automated PCR $(30,31$, 51). The BAX system has been validated against traditional culture methods and is currently approved by several standardisation organisations for Salmonella testing in a variety of foods (22). The real-time PCR based method developed and validated in the present thesis was also compared successfully to the BAX system for detection of Salmonella in artificially contaminated pork filet samples (Manuscript VI).

Quantitative real-time PCR methods for Salmonella will not be discussed in this thesis (for a review see (113)). 


\subsection{PCR detection of Campylobacter}

Numerous conventional, gel-based PCR methods for detection of Campylobacter have been published, targeting a variety of genes and species, and tested on many different sample types. Many of the methods are developed for detection in chicken and chicken products, reflecting the importance of this as a source of human Campylobacter infections $(56,112$, 122, 191). A majority of PCR primers applied for detection of Campylobacter target the $16 \mathrm{~S}$ rRNA gene as in the present thesis, while species specific assays are often designed to recognise the mapA or hipO gene for $C$. jejuni and the ceuE gene for $C$. coli.

For PCR detection of Campylobacter in food, where a relatively low amount of target bacteria is suspected, an enrichment step prior to PCR is often applied. Though adding to the total time of analysis, several advantages are obtained by this: the PCR inhibitory sample constituents are diluted, the level of Campylobacter is increased to allow detection and the ratio between live and dead cells is increased substantially, making the contribution to PCR response from dead cells negligible. Furthermore, in order to meet the legislative demands of detection of $1 \mathrm{CFU} / 25 \mathrm{~g}(12)$, the current techniques available does not leave any option but enrichment of samples with a low level of Campylobacter.

Manuscript I and II, describes the development and validation of a conventional PCR-based method for detection of Campylobacter in chicken carcass rinse and pig swab samples where an enrichment step was employed. This method was shown to have a sensitivity and specificity similar to the current standard culture method (15) both in-house (Manuscript I) and in a multicenter collaborative trial (Manuscript II). Since an internal amplification control (IAC) was also included, the method was found suitable for routine diagnosis. The total time of analysis for negative samples was 2 days for the PCR-based method, compared to 5 days for the culture-based method.

Commercial systems for PCR-detection of Campylobacter likewise employ enrichment steps of 24-48 $\mathrm{h}$ for samples with low contamination levels (iQ-Check ${ }^{\mathrm{TM}}$ Campylobacter kit from Bio-Rad, BAX ${ }^{\circledR}$ from DuPont Qualicon, and TaqMan ${ }^{\circledR}$ Campylobacter jejuni detection kit from Applied Biosystems). The BAX system has obtained AOAC performance approval for qualitative detection of $C$. jejuni, $C$. coli and $C$. lari in ready-to-eat turkey products and chicken carcass rinse samples. 
Methods for detection, differentiation and quantification of Campylobacter spp. in clinical samples have been shown to be more sensitive and reliable, as well as work- and timesaving compared to culture methods $(99,106)$.

PCR assays for post culture identification and differentiation of Campylobacter colonies are increasingly replacing the uncertain biochemical methods described in Section 3.2. Debruyne et al., (2008) presents a comparison study of available assays (55). 


\section{Quantification of Campylobacter}

\subsection{Quantitative real-time PCR}

Several real-time PCR methods for Campylobacter have been described in the literature, albeit most of them concern detection and quantification after enrichment which is a contradiction in terms $(2,133,140,154)$. As shown in Manuscript III, it is possible to establish a linear correlation between the threshold cycle values obtained in real-time PCR and the CFU in enriched samples, but as means of quantification of the original number of Campylobacter cells present in a given sample, such a method is encumbered with uncertainties.

Direct quantitative real-time PCR methods for Campylobacter jejuni and C. coli in poultry have been published (Table 1) $(35,53,77,131,147,191)$. Although, bearing in mind that several of the current control strategies regarding Campylobacter are focused on post slaughter reduction of the number of bacterial cells on the chicken carcass, the usefulness of these real-time PCR methods for quantification could be limited, since they detect all Campylobacter present in a sample, including the dead cells. Furthermore, none of the published methods have been validated, the specificity of the primer sets has not been established according to the current standards, and none of them include an IAC. Another drawback of the majority of these methods is that the standard curves applied to quantify Campylobacter was made from serial dilutions of extracted DNA, not taking into account the fact that the efficiency of DNA extraction can vary substantially with the initial amount of cells (Manuscript V), (44). Finally, the natural variation attributable to the matrix in which the quantification was performed was not thoroughly investigated in any of the methods. This is a prerequisite for successful quantification that would be flawed and encumbered with uncertainties if large natural matrix variation was observed. The variation of the chicken rinse matrix, for which the present method was developed, was evaluated and found to be negligible (Manuscript VIII).

Since the Campylobacter real-time PCR method in the present thesis quantifies C. jejuni, $C$. coli and $C$. lari simultaneously, without differentiation, equal sensitivity and amplification efficiency for all three species has to be assumed. To test this hypothesis, the variation attributable to individual species was investigated on both DNA and cell level. The variance between the three species was not significant on DNA or cell level, proving equal sensitivity 
Table 1. Performance characteristics of the quantitative real-time PCR methods for Campylobacter.

\begin{tabular}{|c|c|c|c|c|c|c|c|}
\hline Target & Linear range & $\mathbf{R}^{2}$ & $\begin{array}{c}\text { Efficiency } \\
\text { (\%) }\end{array}$ & $\begin{array}{c}\text { Limit of } \\
\text { detection }\end{array}$ & $\begin{array}{l}\text { Differentiation } \\
\text { of viable/dead }\end{array}$ & IAC & Reference \\
\hline Campylobacter spp. & 3.8-3.8 $\times 10^{7}$ DNA copies ${ }^{a}$ & 0.99 & 97 & $7 \mathrm{CFU} / \mathrm{ml}$ & No & No & (35) \\
\hline C. jejuni & $1.0-1.0 \times 10^{4} \mathrm{CFU} / \mathrm{ml}^{\mathrm{a}}$ & 0.98 & 96 & 6-15 CFU/PCR & No & No & (191) \\
\hline C. jejuni & $1.0 \times 10^{1}-1.0 \times 10^{6} \mathrm{CFU} / \mathrm{ml}^{\mathrm{a}}$ & - & 96 & $10 \mathrm{CFU} / \mathrm{ml}$ & No & No & (147) \\
\hline C. jejuni and C. coli ${ }^{b}$ & $1.0 \times 10^{1}-1.0 \times 10^{7} \mathrm{CFU} / \mathrm{ml}$ & 0.99 & 86 & $10 \mathrm{CFU} / \mathrm{ml}$ & No & No & $(77)$ \\
\hline C. jejuni & $1.0-1.0 \times 10^{6} \mathrm{CFU} / \mathrm{ml}^{\mathrm{a}}$ & - & 96 & $1 \mathrm{CFU} / \mathrm{ml}$ & No & No & (53) \\
\hline C. jejuni & $1.0 \times 10^{1}-1.0 \times 10^{6} \mathrm{CFU} / \mathrm{ml}$ & 1.00 & 88 & $10 \mathrm{CFU} / \mathrm{PCR}$ & No & No & (131) \\
\hline C. jejuni, C. coli and C. Iari & $1.0 \times 10^{2}-1.0 \times 10^{7} \mathrm{CFU} / \mathrm{ml}$ & 0.99 & 91 & $10 \mathrm{CFU} / \mathrm{PCR}$ & Yes & Yes & Manuscript VIII \\
\hline
\end{tabular}

${ }^{\text {a }}$ Standard made from serial diluted pure DNA

${ }^{\mathrm{b}}$ differentiation and quantification by duplex PCR 
and amplification efficiency of the method independent of species (Manuscript VIII). The standard curve applied for absolute quantification was therefore made from $C$. jejuni CCUG 11284 in Campylobacter-free chicken carcass rinse.

In order to perform correct quantification it is essential that a PCR assay performs with relatively constant amplification efficiency and has a linear range of relevance to the actual sample-response. The linearity of the real-time PCR method was evaluated both on pure DNA in Manuscript III and on cells in Manuscript VIII. In Manuscript III, the number of genomic DNA copies was plotted against the threshold cycle value obtained, and a linear relationship could be established. The number of genomic copies was determined using the equation $m=n\left(1.013 \times 10^{-21}\right)$, where $m$ is the mass, and $n$ the number of base pairs in the genome, determined to be 1,641,481 in C. jejuni NCTC 11168 (139). The linear range was between $5 \times 10^{1}$ and $1 \times 10^{7}$ copies of DNA on the RotorGene instrument, and between $1 \times 10^{3}$ and $1 \times 10^{7}$ copies of DNA on the ABI-PRISM 7700 (Manuscript III). In Manuscript VIII, the linear range of the method was determined to be $1 \times 10^{2}$ to $1 \times 10^{7} \mathrm{CFU} / \mathrm{ml}$ chicken carcass rinse, and the limit of quantification thereby $1 \times 10^{2} \mathrm{CFU} / \mathrm{ml}$, corresponding to $10 \mathrm{CFU} / \mathrm{PCR}$ (Table 1).

The amplification efficiency (AE) was calculated in Manuscript III and VIII using the slope of these linear relationships by the equation $A E=10^{-1 / \text { slope }}-1$ (94), and was determined to be approx. 90\% independent of the thermal cycler (RotorGene 3000, ABI-PRISM 7700, Mx3005P), reflecting the robustness of the assay.

Alternative sample preparation methods for quantitative detection of Campylobacter by PCR have been published. Wolffs et al. (2005) described the use of flotation prior to real-time PCR to quantify viable and VBNC Campylobacter (190). The quantification was performed by applying a discontinuous buoyant density gradient method to separate viable and VBNC cells from the sample matrix and background flora, and amplifying only this cell fraction in PCR. The limit of detection of this flotation-based method was determined to be $8.6 \times 10^{2} \mathrm{CFU} / \mathrm{ml}$ and quantification was possible in the range of $2.6 \times 10^{7}$ down to $2.6 \times 10^{3} \mathrm{CFU} / \mathrm{ml}$ in chicken rinse samples.

The feasibility of large-volume immunocapture of Campylobacter prior to PCR, reducing sample volumes from $250 \mathrm{ml}$ to only $200 \mu \mathrm{l}$ has also been evaluated (121). The cell capture and recovery of Campylobacter was shown to be quite low, and the method only suitable for enriched samples with high levels of target cells. 


\subsection{Differentiation of viable and dead Campylobacter}

As many advantages as the real-time PCR technology offers regarding pathogen detection in mixed populations, a major drawback has been that PCR is not able to distinguish between DNA from viable and dead cells. DNA from dead cells has been shown to persist for up to three weeks following cell death (90). This has been one of the main causes hindering the implementation of PCR in routine diagnostics for food, where quantification of viable bacteria is essential. It is a serious limitation of the PCR technology, which is of particular relevance for Campylobacter, since mitigation strategies are focusing increasingly on post slaughter decontamination, leaving the PCR technology unable to assess the potential for foodborne infections. The presence of DNA from dead Campylobacter can lead to an overestimation of the number of viable cells, and in some instances even to a false positive response (188).

Through the last decades lots of effort has been devoted to develop techniques that allow distinguishing between viable and dead bacteria in mixed populations. However, no ultimate method has been identified, as they all suffer from serious drawbacks (42). Conventional culture to characterise viability of bacteria is time consuming, and it is known that some strains of Campylobacter jejuni can enter a viable but non-culturable (VBNC) state following unfavourable conditions, which is not detected by conventional culture (146). Flow cytometry methods can differentiate between viable and dead bacteria, but are not species specific, and can therefore only be applied in combination with other techniques (37). Specific amplification of mRNA by reverse transcriptase PCR or nucleic acid sequence-based amplification (NASBA) has been applied extensively as a viability marker due to mRNAs intrinsic instability (42). This approach is likewise problematic, since the expression and transcription is relatively unstable, and some mRNA molecules are not transcribed in the VBNC state. Furthermore, using mRNA as a viability marker, several parameters such as physiological cell condition, lethal treatment and period of time after treatment until analysis, extraction and analysis method can influence the result (91). For $C$. jejuni it has been shown that both lethal treatment and post-treatment holding conditions had a marked influence on the results obtained using mRNA as a viability marker (153).

A novel concept for distinguishing between DNA from viable and dead cells employing a prePCR ethidium monoazide (EMA) sample treatment was described by Nogva et al. (2003) and Rudi et al. (2005), (130, 151). EMA $\left(\mathrm{C}_{21} \mathrm{H}_{8} \mathrm{BrN}_{5}\right.$; phenanthridium, 3-amino-8-azido-5-ethyl-6phenyl bromide, Figure 9) can intercalate into the double helical DNA, and upon exposure to intense visible light the ends of the EMA molecule will cross-link the two DNA strands (76), leaving it unavailable for PCR amplification. The intensive visible light exposure will 
simultaneously convert the free EMA in the sample to hydroxylamine that will no longer cross-link DNA (Figure 9).

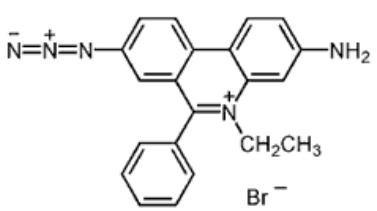

A. Ethidium monoazide

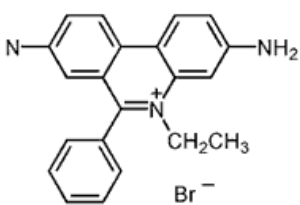

B. Nitrene

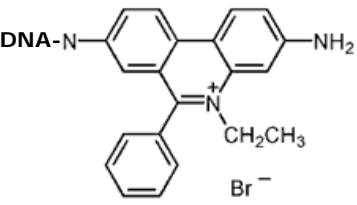

C. Cross-link with DNA

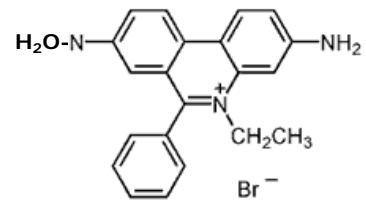

D. Hydroxylamino ethidium

Figure 9. Structural changes of EMA following photoactivation. A: Ethidium monoazide in its native structure. B: The azide group is converted to nitrene following visible light exposure. C: The DNA intercalated EMA binds covalently to DNA via the nitrene following light exposure. D: The unbound EMA reacts with water upon light exposure forming hydroxylamino ethidium.

Viable cells with intact cell membranes have been shown to be relatively impermeable to EMA, hence treating a sample with EMA followed by photolysis will result in a real-time PCR signal from only viable bacteria. The principle of EMA-PCR is shown in Figure 10.

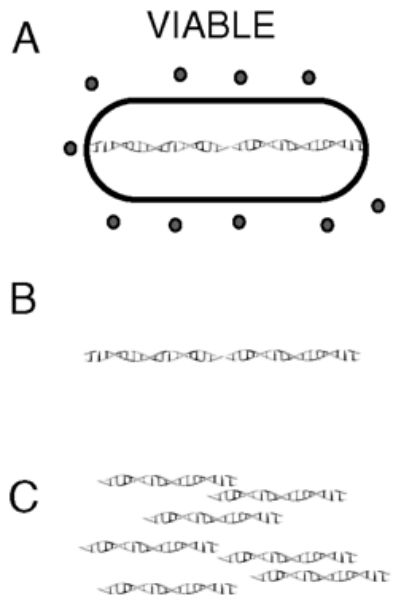

Figure 10. The principle of EMA-PCR. Adapted with permission from Rudi et al., 2005 (151). A) EMA is added to a sample pre-PCR and during a short incubation it intercalates into the accessible double helical DNA of cells with permeable membranes. The sample is exposed to intensive visible light for a fixed period of time, and the two DNA strands are cross-linked irreversibly by EMA, while the unbound EMA is converted into hydroxylamine. B) After DNA extraction two fractions of DNA are present; the EMA cross-linked arising from dead cells and the unstained fraction arising from viable cells. C) The unstained DNA fraction will be denatured and amplified in the PCR, while the cross-linked DNA will not be available for PCR amplification.

The principle of EMA-PCR has however been questioned in a study by Nocker and Camper (2006), where it was suggested that the reduced PCR signal from EMA treated dead bacterial cells, to a considerable extend, was due to loss of EMA-bound DNA during DNA extraction, rather than inhibition of amplification (128). Their findings suggest that the EMA-DNA conjugates from dead cells are cross-linked to other cell components and pelleted together 
with cell debris during the centrifugation step applied in the DNA extraction. This theory was disputed by Hein et al. (2006), as being unsubstantiated (75), and the general understanding of the mechanism remains as shown in Figure 10.

EMA has been applied successfully in several studies to differentiate between viable and dead Klebsiella oxytoca, Escherichia coli 0157:H7, Salmonella enterica subsp. enterica serovar Typhimurium, Listeria monocytogenes and Vibrio vulnificus (128-130, 159, 160, 182). Furthermore, it has been shown to selectively allow a PCR signal from viable $L$. monocytogenes on cheese and in milk, $C$. jejuni on chicken meat, and viable microflora from fish fillets $(103,104,150,151,159)$.

In later studies, EMA has been reported to penetrate the cell membrane of intact viable cells. EMA concentrations of 10 and $100 \mu \mathrm{g} / \mathrm{ml}$ killed all viable Anoxybacillus flavithermus in milk powders, while concentrations of 0.1 and $1 \mu \mathrm{g} / \mathrm{ml}$ resulted in survival rates of $58 \%$ and $0.75 \%$ (152). Also for L. monocytogenes, E. coli 0157:H7, Micrococcus luteus, Mycobacterium avium, Pseudomonas syringae, Staphylococcus aureus and Enterobacter sakazakii EMA treatment resulted in a loss of genomic DNA from viable cells $(41,129,135)$. The viability of these bacteria was compromised, in varying degrees, and the conclusion drawn from these studies was that viable cells are not exclusively impermeable to EMA. Since the permeability differs with the particular bacterial species, the agent can not be regarded as generally membrane impermeable, and therefore real-time PCR analysis of EMA-treated samples will lead to unpredictable underestimations of the number of viable cells.

In 2006, Nocker et al. published a study where EMA was replaced by propidium monoazide (PMA, C27H33Cl2 $\mathrm{N}_{6}$, phenanthridium, 3-amino-8-azido-5[3-(diethylmethylammonio)propyl]6-phenyl dichloride) to differentiate between viable and dead bacteria by selective removal of DNA from dead cells (129). PMA was found exclusively in cells with compromised membranes, and it was demonstrated that no uptake occurred in cells with intact cell walls. The reason for this enhanced impermeability has been ascribed to the higher charge of the PMA molecule, which has two positive charges compared to only one for EMA. PMA is a chemical alteration (additional azide group) of propidium iodide ( $\mathrm{PI})$, one of the most frequently applied membrane-impermeable dyes in flow cytometry, and can be expected to have the same permeability potential as PI. This is of great value in a food safety perspective, since PI only penetrates permeabilised cells, and not the reproductively viable, metabolically active or cells with intact membranes, which can be resuscitated and therefore hold the potential of infection (126). 


\subsection{Post-slaughter quantification of viable Campylobacter on chickens}

Real-time PMA-PCR has been successfully applied for quantification of viable $L$. monocytogenes (135) and E. coli 0157:H7 (129), however these experiments were performed using laboratory cultured strains, not on naturally infected samples with the bacteria imbedded in a food matrix. In the present thesis, a PMA sample treatment was applied prior to direct quantitative real-time PCR on Campylobacter in chicken carcass rinse from 50 naturally infected chickens from a Campylobacter-positive flock (Manuscript VIII).

The chickens were collected at the abattoir immediately after cooling, and the number of Campylobacter in the chicken carcass rinse samples was determined in parallel by real-time PCR (with and without PMA sample-treatment) and conventional culture (13). The standards (Figure 11) were included in every PCR analysis and the quantity of Campylobacter in the naturally infected chickens was determined by extrapolation from the threshold cycle value obtained. Out of the 50 chickens, 42 were found Campylobacter-positive by culture, 45 by real-time PCR with PMA-treatment, and 48 by real-time PCR without PMA-treatment. The culture-negative/Q-PCR-positive chickens were shown to harbour low levels of Campylobacter, below the quantification limit of the Q-PCR. The same applied for chickens found Campylobacter-positive by Q-PCR without PMA-treatment, but Campylobacternegative with PMA-treatment. The level of infection in the Campylobacter-positive chicken carcass rinses ranged from 25 to $1.5 \times 10^{6} \mathrm{CFU} / \mathrm{ml}$, reflecting the post-slaughter difference in contamination within a flock.

The results obtained clearly showed a reduced signal in real-time PCR from the samples that had received PMA-treatment prior to PCR compared to the untreated parallel samples, indicating presence of DNA from dead Campylobacter cells. The signal-reduction was positively correlated to the level of Campylobacter in the samples, and a range of reduction from $1 \times 10^{2}$ to $2.4 \times 10^{6}$ Campylobacter cell equivalents (CCE)/ml was observed.

The PMA-PCR quantification compared favourably to direct culture-based detection of Campylobacter. Analysis of variance comparing Q-PCR (with and without PMA) to plate counts on mCCDA, showed that Q-PCR with PMA-treatment produced results that were statistically significantly closer to counts on mCCDA $(P<0.001)$ than Q-PCR without PMAtreatment. The relative specificity of the PMA-PCR method was $100 \%$, and it was shown to be more sensitive than the culture-based method (Manuscript VIII).

The results obtained from PMA-PCR corresponded well to those obtained by culture, suggesting that VBNC Campylobacter were not present in great numbers in the samples. 
However, these chickens were collected immediately after cooling at the abattoir and the ratio between viable and VBNC cells can only be expected to decrease as a consequence of food processing and storage, thus presenting a possible diagnostic uncertainty. Furthermore, post slaughter mitigation strategies to reduce the number of viable Campylobacter on chicken carcasses, will most certainly contribute to the number of VBNC cells. As long as the infectious potential of the Campylobacter VBNC state is not clarified, quantitative methods for risk assessment should detect these as well.

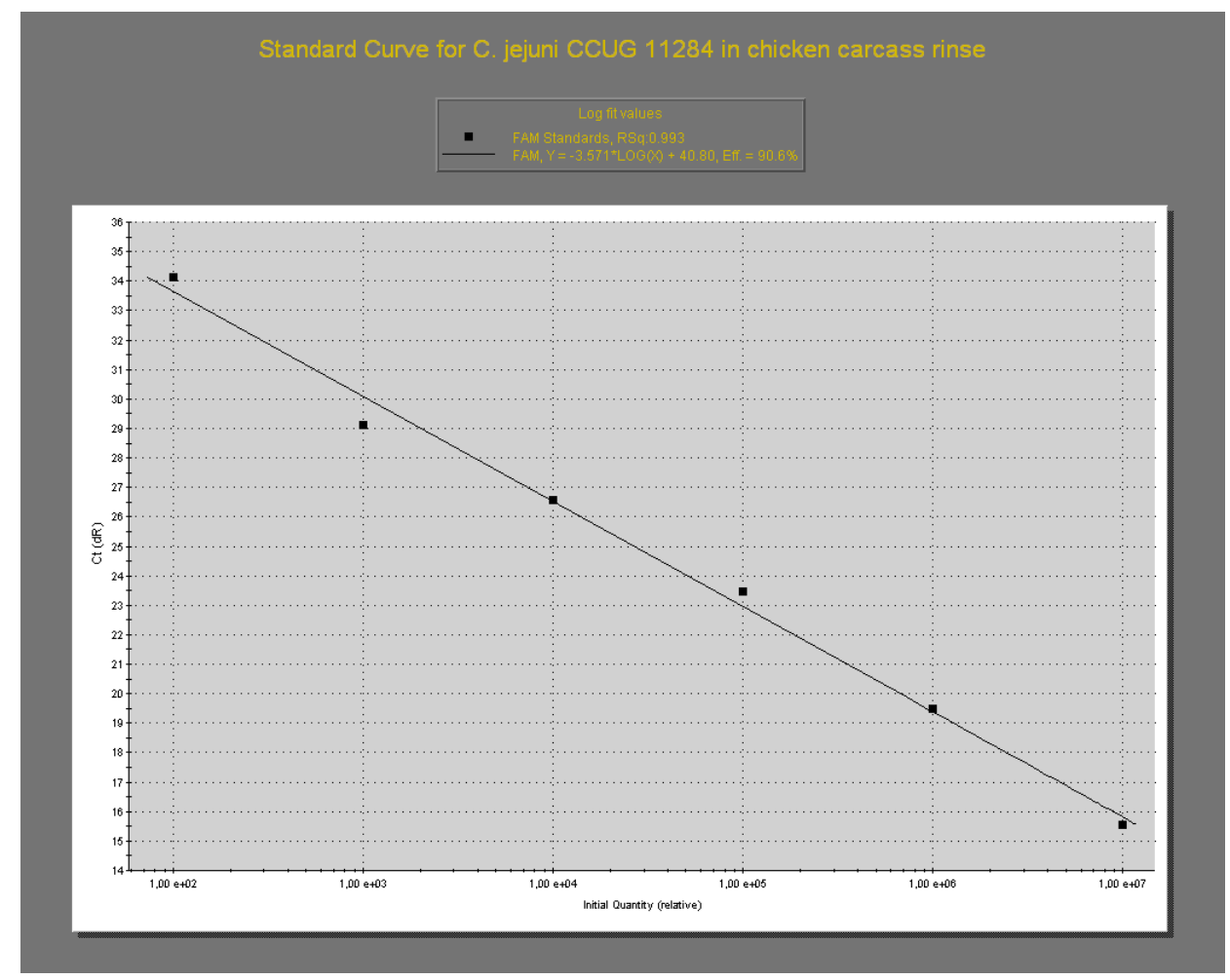

Figure 11. Standard curve applied for absolute quantification of Campylobacter in naturally infected chickens, showing the initial quantity on the $x$-axis and the corresponding threshold cycle value on the $y$-axis. The standard was prepared by duplicate PCR analyses of DNA extracted from $1 \mathrm{ml}$ chicken carcass rinse inoculated with $1 \times 10^{2}$ to $1 \times 10^{7}$ CFU. The standard was included in every PCR analysis, and the quantity of Campylobacter in the naturally infected chickens was determined by extrapolating a quantity from the threshold cycle value obtained.

It has been demonstrated in several studies comparing Q-PCR to culture-based enumeration, that higher counts were produced by Q-PCR, which has been explained by the detection of DNA from dead and VBNC cells $(35,77,191)$. In the present thesis, this was also true for the PMA-untreated samples. However, when the PMA-treatment was applied a slightly lower PCR quantification was often observed (Manuscript VIII). The reason for this could partly be due to underestimation of the cell input in the standard applied for quantification, but also due to overestimation of the number of Campylobacter colonies on the mCCDA plates. 
Verification of colonies from the selective plates did indicate that not all Campylobacter-like colonies could in fact be confirmed as being $C$. jejuni, $C$. coli or $C$. lari, substantiating this theory. Another issue that has to be considered in this regard, is that the cell state and permeability of the cell wall is not a clear cut reflection of a viable or dead cell, and PMA could have entered a minor fraction of culturable cells.

The quantification limit of the present PMA-PCR does not meet the legislative demands of detection of $1 \mathrm{CFU} / 25 \mathrm{~g}$ (12). No available technology can enable direct PCR detection of 1 Campylobacter in $25 \mathrm{~g}$. Adding to this dilemma, preliminary experiments also showed that a rinsing volume of $50 \mathrm{ml}$, far from recovered all the Campylobacter cells present on a chicken carcass. However, a rinsing volume of $310 \mathrm{ml}$ was applied in a study by Jørgensen et al. (2002), and similar recovery rates to the present thesis was found (89). This factor has to be considered in estimating the level of infection and whole carcass contamination. Direct QPCR methods for Campylobacter are albeit applicable as tools for risk assessment and assurance of food safety, since it has been shown that a strong positive correlation exists between the number of Campylobacter on chickens and the risk of human infections (118, $148,163)$. 


\section{Concluding remarks}

The incidence and significance of foodborne diseases is escalating worldwide. The globalisation of the food supply, changes in the food production system as well as in the human and microbiological populations has led to an increased frequency of infection. In order to prevent and control two of the most important foodborne pathogens i.e. Salmonella and Campylobacter, improved detection methods are imperative. Rapid and reliable methods that can quantify and discriminate between viable and dead bacteria present in the food chain, can contribute to our knowledge on the fate of bacteria throughout the production chain, of transmission routes, persistence and prevalence, hence forming the basis for development of intervention and elimination strategies.

Even though the PCR technology offers valuable advantages compared to culture-based standard methods, the implementation of this technique has made slow progress. A lack of validated standard methods has made reproducibility of results difficult, and the fact that PCR response from dead cells could obscure the diagnostic outcome of the test has also been an impediment.

The focus of the present thesis has been to improve molecular-based methods for detection and quantification of Salmonella and Campylobacter. The thesis has described the development and validation of qualitative and quantitative PCR-based methods for these pathogens. The quantitative real-time PCR-method for Campylobacter was furthermore combined with a PMA-treatment to enable detection of viable target cells only. This method presents a cost-effective diagnostic tool ready to apply in industry and control laboratories, not detecting DNA from dead Campylobacter, but recognising the infectious potential of the VBNC state, and thereby able to assess the outcome and impact of new mitigation strategies.

The methods presented in this thesis could advantageously replace culture-based detection and quantification methods, and thereby reduce the time and cost of standard food analysis for Salmonella and Campylobacter. The rapid screening for negative, and identification of positive, samples, would contribute to food safety, assessment and prolongation of shelf life and, in addition, liberate resources to focus on suspected positive samples regarding typing and source tracing. The methods are particularly suitable for studying the fate of these bacteria throughout the process chain from farm to fork, in elucidating the effect of process steps in terms of reducing, eliminating or inactivating food pathogens introduced at various 
steps. Thus, the methods can be used for risk assessment and evaluation of risk mitigating interventions.

In conclusion, this thesis will contribute to the dissemination of PCR-based detection methods for Salmonella and Campylobacter. 


\section{Acknowledgements}

This work was carried out at the Molecular Diagnostics group at the National Food Institute, Technical University of Denmark. It was funded in part by EC (grant no. QLK1-CT-199900226), Directorate for Food, Fisheries and Agri Business (grant no. 3401-66-03-5 and 341404-01032), CampyFood project of the Nordic Innovation Centre (grant no. F040301), Nordic Council of Ministers (grant no. 681048-05317), EU project FoodPCR 2 (FOOD-CT-2004506122) and BIOTRACER (contract 036272).

First, I would like to express my thanks and sincere gratitude to my supervisors Professor John Elmerdahl Olsen and Professor Jeffrey Hoorfar for their support, guidance and encouragement throughout the project.

Likewise, I would like to thank my co-supervisors Dorte Lau Baggesen and Charlotta Löfström for their advice, support and help during the project. A special thanks to Lotta for always taking the time for assisting in solving problems and giving lots of valuable advice, no matter what the subject.

Thank you to all of my colleagues that have contributed with scientific help and advice: Burkhard Malorny, Flemming Hansen, Helle Sommer, Hugo Grønlund, Julia Chrsitensen, Katja Olsen, Kirsten Michaelis, Laurids Siig Christensen, Liselotte Folling, Marianne Lund, Michael Krause, Pia Engelsman, Sven Qvist and Tina Beck Hansen, and to all the others for creating such a pleasant environment.

I also wish to thank the industrial partners that have been part of the various projects: Danish Meat Association, Danpo A/S, Ilochip, COOP Denmark, Tican and Danish Crown.

During my Ph.d. I have conducted several ring-trials for collaborative validation of methods, and I would like to thank the participants for their willingness to take part in them, even though time and resources were often scarce.

Finally, a warm thanks to my beloved family and friends for being who they are. 


\section{References}

1. Abu Al-Soud, W. and P. Radstrom. 1998. Capacity of nine thermostable DNA polymerases To mediate DNA amplification in the presence of PCR-inhibiting samples. Appl. Environ. Microbiol. 64:3748-3753.

2. Abu-Halaweh, M., J. Bates, and B. K. Patel. 2005. Rapid detection and differentiation of pathogenic Campylobacter jejuni and Campylobacter coli by real-time PCR. Res. Microbiol. 156:107-114.

3. Afonina, I. A., M. W. Reed, E. Lusby, I. G. Shishkina, and Y. S. Belousov. 2002. Minor groove binder-conjugated DNA probes for quantitative DNA detection by hybridizationtriggered fluorescence. BioTechniques 32:940-4, 946-9.

4. Agarwal, A., A. Makker, and S. K. Goel. 2002. Application of the PCR technique for a rapid, specific and sensitive detection of Salmonella spp. in foods. Mol. Cell. Probes 16:243250.

5. Altekruse, S. F., D. L. Swerdlow, and N. J. Stern. 1998. Microbial food borne pathogens. Campylobacter jejuni. Vet. Clin. North Am. Food Anim. Pract. 14:31-40.

6. Amar, C. F., C. L. East, J. Gray, M. Iturriza-Gomara, E. A. Maclure, and J. McLauchlin. 2007. Detection by PCR of eight groups of enteric pathogens in 4,627 faecal samples: reexamination of the English case-control Infectious Intestinal Disease Study (1993-1996). Eur. J. Clin. Microbiol. Infect. Dis. 26:311-323.

7. Andrews, W. H. and T. S. Hammack. 2000. Bacteriological Analytical Manual. Chapter 5. Salmonella. 8th Ed. US. Food and Drug Administration. Available from: http://www.cfsan.fda.gov/ ebam/bam-mm.html.

8. Anonymous. 2009. The Community Summary Report on Trends and Sources of Zoonoses and Zoonotic Agents in the European Union in 2007. The EFSA Journal.

9. Anonymous. 2009. Annual report on zoonosis in Denmark 2007. National Food Institute, Technical University of Denmark.

10. Anonymous. 2009. Protocol for the validation of alternative microbiological methods. Nordic Committee on Food Analysis (NMKL). NordVal, Oslo, Norway.

11. Anonymous. 2006. Annual report on zoonosis in Denmark 2006. National Food Institute, Technical University of Denmark.

12. Anonymous. 2006. Microbiology of food and animal feeding stuffs - Horizontal method for detection and enumeration of Campylobacter spp. Part 1: Detection method. ISO 102721. International Standard Organisation (ISO), Geneva, Switzerland. 
13. Anonymous. 2005. Thermotolerant Campylobacter. Detection and enumeration in foods. NMKL 119. Nordic Committee on Food Analysis (NMKL), Esbo, Finland.

14. Anonymous. 1997. Foodborne pathogens - A review for the practical microbiologist and food technologist. Campden \& Chorleywood, Food Research Association.

15. Anonymous. 1995. Microbiology of Food and Animal Feeding Stuffs - Horizontal Method for detection of thermotolerant Campylobacter ISO 10272. International Standard Organisation (ISO), Geneva, Switzerland.

16. Anonymous. 2002. Microbiology of food and animal feeding stuffs - Horizontal method for the detection of Salmonella spp. ISO 6579. International Standard Organisation (ISO), Geneva, Switzerland.

17. Anonymous. 2000. Campylobacter. World Health Organisation (WHO). Available from: http://www.who.int/mediacentre/factsheets/fs255/en/print.html.

18. Anonymous. 1999. Salmonella. Detection in food, NMKL 71. Nordic Committee on Food Analysis, Åbo, Finland.

19. Anonymous. Scorpion probe chemistry. Available from: www.dxsgenotyping.com/technology.htm.

20. Anonymous. Salmonellosis. Center for disease control and prevention (CDC). Available from: http://www.cdc.gov/nczved/dfbmd/disease_listing/salmonellosis_gi.html\#8.

21. Anonymous. Drug-resistant Salmonella. World Health Organisation (WHO). Available from: http://www.who.int/mediacentre/factsheets/fs139/en/.

22. Anonymous. Bax Sytem PCR assay Salmonella. DuPont Qualicon. Available from: http://www2.dupont.com/Qualicon/en_US/products/BAX_System/bax_salmonella.html.

23. Anonymous. Salmonella. Investigation update: Outbreak of Salmonella Typhimurium infections 2008-2009. Center for disease control and prevention. Available from: http://www.cdc.gov/salmonella/typhimurium/update.html.

24. Anonymous. Nyheder. 3. februar 2009 - Status på det landsdækkende Salmonellaudbrud uge 5. Statens Serum Institut. Available from:

http://www.ssi.dk/sw174.asp?PAGE=1\&ArtNo=3647090.

25. Anonymous. Principle of PCR. Available from:

http://fmel.ifas.ufl.edu/buzz/images/pcr.jpg. 
26. Anonymous. Scorpion probe chemistry. Available from:

http://upload.wikimedia.org/wikipedia/commons/1/12/Scorpions_Probes.jpg.

27. Anonymous. NordVal certificate Campylobacter real-time PCR. Available from: http://www.nmkl.org/NordVal/Sertifikater/NordVal017.pdf.

28. Anonymous. NordVal certificate Salmonella detection method by PCR. Available from: http://www.nmkl.org/NordVal/Sertifikater/NordVal031.pdf.

29. Baffone, W., A. Casaroli, B. Citterio, L. Pierfelici, R. Campana, E. Vittoria, E. Guaglianone, and G. Donelli. 2006. Campylobacter jejuni loss of culturability in aqueous microcosms and ability to resuscitate in a mouse model. Int. J. Food Microbiol. 107:83-91.

30. Bailey, J. S. 1998. Detection of Salmonella cells within 24 to 26 hours in poultry samples with the polymerase chain reaction BAX system. J. Food Prot. 61:792-795.

31. Bennett, A. R., D. Greenwood, C. Tennant, J. G. Banks, and R. P. Betts. 1998. Rapid and definitive detection of Salmonella in foods by PCR. Lett. Appl. Microbiol. 26:437-441.

32. Black, R. E., M. M. Levine, M. L. Clements, T. P. Hughes, and M. J. Blaser. 1988. Experimental Campylobacter jejuni infection in humans. J. Infect. Dis. 157:472-479.

33. Blaser, M. J., H. L. Hardesty, B. Powers, and W. L. Wang. 1980. Survival of Campylobacter fetus subsp. jejuni in biological milieus. J. Clin. Microbiol. 11:309-313.

34. Blivet, D., G. Salvat, F. Humbert, and P. Colin. 1998. Development of a new culture medium for the rapid detection of Salmonella by indirect conductance measurements. J. Appl. Microbiol. 84:399-403.

35. Botteldoorn, N., E. Van Coillie, V. Piessens, G. Rasschaert, L. Debruyne, M. Heyndrickx, L. Herman, and W. Messens. 2008. Quantification of Campylobacter spp. in chicken carcass rinse by real-time PCR. J. Appl. Microbiol. 105:1909-1918.

36. Braasch, D. A. and D. R. Corey. 2001. Locked nucleic acid (LNA): fine-tuning the recognition of DNA and RNA. Chem. Biol. 8:1-7.

37. Breeuwer, P. and T. Abee. 2000. Assessment of viability of microorganisms employing fluorescence techniques. Int. J. Food Microbiol. 55:193-200.

38. Burgos, J. S., C. Ramirez, R. Tenorio, I. Sastre, and M. J. Bullido. 2002. Influence of reagents formulation on real-time PCR parameters. Mol. Cell. Probes 16:257-260.

39. Burkardt, H. J. 2000. Standardization and quality control of PCR analyses. Clin. Chem. Lab. Med. 38:87-91. 
40. Cassar, R. and P. Cuschieri. 2003. Comparison of Salmonella chromogenic medium with DCLS agar for isolation of Salmonella species from stool specimens. J. Clin. Microbiol. 41:3229-3232.

41. Cawthorn, D. M. and R. C. Witthuhn. 2008. Selective PCR detection of viable Enterobacter sakazakii cells utilizing propidium monoazide or ethidium bromide monoazide. J. Appl. Microbiol. 105:1178-85.

42. Cenciarini-Borde, C., S. Courtois, and B. La Scola. 2009. Nucleic acids as viability markers for bacteria detection using molecular tools. Future Microbiol. 4:45-64.

43. Chen, S., A. Yee, M. Griffiths, C. Larkin, C. T. Yamashiro, R. Behari, C. Paszko-Kolva, K. Rahn, and S. A. De Grandis. 1997. The evaluation of a fluorogenic polymerase chain reaction assay for the detection of Salmonella species in food commodities. Int. J. Food Microbiol. 35:239-250.

44. Cook, L., E. E. Atienza, A. Bagabag, R. M. Obrigewitch, and K. R. Jerome. 2009. Comparison of methods for extraction of viral DNA from cellular specimens. Diagn. Microbiol. Infect. Dis. 64:37-42.

45. Cooke, F. J., E. J. Threlfall, and J. Wain. 2007. Current trends in the spread and occurence of human salmonellosis: Molecular typing and emerging antibiotic resistance. $p$. 1-29. In M. Rhen, D. Maskell, P. Mastroeni and E. J. Threlfall (Eds.), Salmonella. Molecular biology and pathogenesis. Horizon Bioscience, Norfolk, UK.

46. Costa, J. M., P. Ernault, M. Olivi, T. Gaillon, and K. Arar. 2004. Chimeric LNA/DNA probes as a detection system for real-time PCR. Clin. Biochem. 37:930-932.

47. Crump, J. A., S. P. Luby, and E. D. Mintz. 2004. The global burden of typhoid fever. Bulletin of the World Health Organisation 82:346-353.

48. D'Aoust, J. Y. 1997. Salmonella species, p. 129-158. In M. P. Doyle, L. R. Beuchat and T. J. Montville (Eds.), Food Microbiology. Fundamentals and Frontiers. ASM Press, Washington D.C.

49. D'Aoust, J. Y. 1991. Psychrotrophy and foodborne Salmonella. Int. J. Food Microbiol. 13:207-215.

50. D'Aoust, J. Y. 1989. Salmonella., p. 327-445. In M. P. Doyle (Ed.), Foodborne Bacterial Pathogens. Marcel Dekker Inc., New York.

51. D'Aoust, J. Y., F. Pagotto, M. Akhtar, J. Bussey, C. Cooper, C. McDonald, M. Meymandy, and K. Tyler. 2007. Evaluation of the BAX gel and fluorometric systems for the detection of foodborne Salmonella . J. Food Prot. 70:835-840. 
52. De Smedt, J. M. e. a.,. 1986. Rapid Salmonella detection in foods by motility enrichment on a modified semisolid Rappaport-Vassiliadis medium. J. Food Prot. 49:510.

53. Debretsion, A., T. Habtemariam, S. Wilson, D. Nganwa, and T. Yehualaeshet. 2007. Real-time PCR assay for rapid detection and quantification of Campylobacter jejuni on chicken rinses from poultry processing plant. Mol. Cell. Probes 21:177-181.

54. Debruyne, L., D. Gevers, and P. Vandamme. 2008. Taxonomy of the family Campylobactericeae, p. 3-25. In I. Nachamkin, C. M. Szymanski and M. J. Blaser (Eds.), Campylobacter. ASM Press, Washinton, DC.

55. Debruyne, L., E. Samyn, E. De Brandt, O. Vandenberg, M. Heyndrickx, and P. Vandamme. 2008. Comparative performance of different PCR assays for the identification of Campylobacter jejuni and Campylobacter coli. Res. Microbiol. 159:88-93.

56. Denis, M., J. Refregier-Petton, M. J. Laisney, G. Ermel, and G. Salvat. 2001. Campylobacter contamination in French chicken production from farm to consumers. Use of a PCR assay for detection and identification of Campylobacter jejuni and Camp. coli. J. Appl. Microbiol. 91:255-267.

57. Eigner, U., R. Reissbrodt, R. Hammann, and A. M. Fahr. 2001. Evaluation of a new chromogenic medium for the isolation and presumptive identification of Salmonella species from stool specimens. Eur. J. Clin. Microbiol. Infect. Dis. 20:558-565.

58. Ellingson, J. L., J. L. Anderson, S. A. Carlson, and V. K. Sharma. 2004. Twelve hour realtime PCR technique for the sensitive and specific detection of Salmonella in raw and readyto-eat meat products. Mol. Cell. Probes 18:51-57.

59. Erlich, H. A. 1989. Polymerase chain reaction. J. Clin. Immunol. 9:437-447.

60. Eyigor, A., K. T. Carli, and C. B. Unal. 2002. Implementation of real-time PCR to tetrathionate broth enrichment step of Salmonella detection in poultry. Lett. Appl. Microbiol. 34:37-41.

61. Federighi, M., J. L. Tholozan, J. M. Cappelier, J. P. Tissier, and J. L. Jouve. 1998. Evidence of non-coccoid viable but non-culturable Campylobacter jejuni cells in microcosm water by direct viable count, CTC-DAPI double staining, and scanning elctron microscopy. Food Microbiol. 15:539-550.

62. Ferreira, M. A. S. S. and B. M. Lund. 1987. The influence of $\mathrm{pH}$ and temperature on initiation of growth of Salmonella spp. Lett. Appl. Microbiol. 5:67-70.

63. Ferreira-Gonzalez, A., S. Yanovich, M. R. Langley, L. A. Weymouth, D. S. Wilkinson, and C. T. Garrett. 2000. Enhanced analytical sensitivity of a quantitative PCR for CMV using a modified nucleic-acid extraction procedure. J. Clin. Lab. Anal. 14:32-37. 
64. Fleet, G. H. 1999. Microorganisms in food ecosystems. Int. J. Food Microbiol. 50:101-117.

65. Forsythe, S. J. 2000. Food poisening microorganisms, p. 87-148. In S. J. Forsythe (Ed.), The microbiology of safe food. Blackwell Science Publishers, Abingdon.

66. Fricker, C. R. 1984. A comparison of methods for the isolation of salmonellae from sewage sludge. Zentralbl. Bakteriol. Mikrobiol. Hyg. B. 179:170-178.

67. Gado, I., P. Major, M. Kiraly, and M. G. Plaveczky. 2000. Rapid combined assay for Salmonella detection in food samples. Acta Microbiol. Immunol. Hung. 47:445-456.

68. Gaillot, O., P. di Camillo, P. Berche, R. Courcol, and C. Savage. 1999. Comparison of CHROMagar Salmonella medium and hektoen enteric agar for isolation of salmonellae from stool samples. J. Clin. Microbiol. 37:762-765.

69. Galan, J. E. and R. Curtiss 3rd. 1991. Distribution of the invA, $-B,-C$, and $-D$ genes of Salmonella typhimurium among other Salmonella serovars: invA mutants of Salmonella typhi are deficient for entry into mammalian cells. Infect. Immun. 59:2901-2908.

70. Galanis, E., D. M. Lo Fo Wong, M. E. Patrick, N. Binsztein, A. Cieslik, T. Chalermchikit, A. Aidara-Kane, A. Ellis, F. J. Angulo, H. C. Wegener, and World Health Organization Global Salm-Surv. 2006. Web-based surveillance and global Salmonella distribution, 2000-2002. Emerg. Infect. Dis. 12:381-388.

71. Gray, L. D. 1995. Escherichia, Salmonella, Shigella and Yersinia., p. 450. In P. R. Murray, E. J. Baron, M. A. Pfaller, F. C. Tenover and R. H. Yolken (Eds.), Manual of Clinical Microbiology. ASM press, Washington D.C.

72. Grimont, A. D. and F. X. Weill. 2007. Antigenic formulae of the Salmonella serovars. $9^{\text {th }}$ edition. 1-166.

73. Hald, B., K. Knudsen, P. Lind, and M. Madsen. 2001. Study of the infectivity of salinestored Campylobacter jejuni for day-old chicks. Appl. Environ. Microbiol. 67:2388-2392.

74. Hein, I., G. Flekna, M. Krassnig, and M. Wagner. 2006. Real-time PCR for the detection of Salmonella spp. in food: An alternative approach to a conventional PCR system suggested by the FOOD-PCR project. J. Microbiol. Methods 66:538-547.

75. Hein, I., G. Flekna, M. Wagner, A. Nocker, and A. K. Camper. 2006. Possible errors in the interpretation of ethidium bromide and PicoGreen DNA staining results from ethidium monoazide-treated DNA. Appl. Environ. Microbiol. 72:6860-1; author reply 6861-2.

76. Hixon, S. C., W. E. White Jr, and K. L. Yielding. 1975. Selective covalent binding of an ethidium analog to mitochondrial DNA with production of petite mutants in yeast by photoaffinity labelling. J. Mol. Biol. 92:319-329. 
77. Hong, J., Woo Kyung Jung, Jun Man Kim, So Hyun Kim, Hye Cheong Koo, J. Ser, and Y. H. Park. 2007. Quantification and differentiation of Campylobacter jejuni and Campylobacter coli in raw chicken meats using a real-time PCR method. J. Food Prot. 70:2015-2022.

78. Hoorfar, J. and N. Cook. 2003. Critical aspects of standardization of PCR. Methods Mol. Biol. 216:51-64.

79. Hoorfar, J. and A. V. Mortensen. 2000. Improved culture methods for isolation of Salmonella organisms from swine feces. Am. J. Vet. Res. 61:1426-1429.

80. Hoorfar, J., B. Malorny, A. Abdulmawjood, N. Cook, M. Wagner, and P. Fach. 2004. Practical considerations in design of internal amplification controls for diagnostic PCR assays. J. Clin. Microbiol. 42:1863-1868.

81. Hoorfar, J., N. Cook, B. Malorny, M. Wagner, D. De Medici, A. Abdulmawjood, and P. Fach. 2004. Diagnostic PCR: making internal amplification control mandatory. J. Appl. Microbiol. 96:221-222.

82. Humphrey, T. 2006. Public health aspects of Salmonella enterica in food production, $\mathrm{p}$. 89-116. In P. Mastroeni and D. Maskell (Ed.), Salmonella infections. Clinical, Immunological and Molecular Aspects. Cambridge University Press, New York.

83. Humphrey, T. 2004. Salmonella, stress responses and food safety. Nat. Rev. Microbiol. 2:504-509.

84. Humphrey, T. J. 1995. Human campylobacter infections: epidemiology and control. Sci. Prog. 78:135-146.

85. Hunt, J. M., C. Abeyta, and T. Tran. 1998. Campylobacter In Bacteriological Analytical Manual, $8^{\text {th }}$ Edition. U.S. Food and Drug Administration (FDA). Available from: http://www. fda.gov/Food/ScienceResearch/LaboratoryMethods/BacteriologicalAnalyticalManualBAM/u cm072616.htm.

86. Jensen, A. N., A. Dalsgaard, A. Stockmarr, E. M. Nielsen, and D. L. Baggesen. 2006. Survival and transmission of Salmonella enterica serovar typhimurium in an outdoor organic pig farming environment. Appl. Environ. Microbiol. 72:1833-1842.

87. Jensen, A. N., G. Sorensen, D. L. Baggesen, R. Bodker, and J. Hoorfar. 2003. Addition of Novobiocin in pre-enrichment step can improve Salmonella culture protocol of modified semisolid Rappaport-Vassiliadis. J. Microbiol. Methods 55:249-255.

88. Joosten, H., E. Bidlas, and N. Garofalo. 2006. Salmonella detection in probiotic products. Int. J. Food Microbiol. 110:104-107. 
89. Jorgensen, F., R. Bailey, S. Williams, P. Henderson, D. R. Wareing, F. J. Bolton, J. A. Frost, L. Ward, and T. J. Humphrey. 2002. Prevalence and numbers of Salmonella and Campylobacter spp. on raw, whole chickens in relation to sampling methods. Int. J. Food Microbiol. 76:151-164.

90. Josephson, K. L., C. P. Gerba, and I. L. Pepper. 1993. Polymerase chain reaction detection of nonviable bacterial pathogens. Appl. Environ. Microbiol. 59:3513-3515.

91. Keer, J. T. and L. Birch. 2003. Molecular methods for the assessment of bacterial viability. J. Microbiol. Methods 53:175-183.

92. Kim, C. H., M. Khan, D. E. Morin, W. L. Hurley, D. N. Tripathy, M. Kehrli Jr, A. O. Oluoch, and I. Kakoma. 2001. Optimization of the PCR for detection of Staphylococcus aureus nuc gene in bovine milk. J. Dairy Sci. 84:74-83.

93. Klancnik, A., B. Guzej, P. Jamnik, D. Vuckovic, M. Abram, and S. S. Mozina. 2009. Stress response and pathogenic potential of Campylobacter jejuni cells exposed to starvation. Res. Microbiol. (Epub ahead of print).

94. Klein, D., P. Janda, R. Steinborn, M. Muller, B. Salmons, and W. H. Gunzburg. 1999. Proviral load determination of different feline immunodeficiency virus isolates using realtime polymerase chain reaction: influence of mismatches on quantification. Electrophoresis 20:291-299.

95. Knutsson, R., C. Löfström, H. Grage, J. Hoorfar, and P. Rådstrom. 2002. Modeling of 5' nuclease real-time responses for optimization of a high-throughput enrichment PCR procedure for Salmonella enterica. J. Clin. Microbiol. 40:52-60.

96. Koch, W. H. 2004. Technology platforms for pharmacogenomic diagnostic assays. Nat. Rev. Drug Discov. 3:749-761.

97. Kubista, M., J. M. Andrade, M. Bengtsson, A. Forootan, J. Jonak, K. Lind, R. Sindelka, R. Sjoback, B. Sjogreen, L. Strombom, A. Stahlberg, and N. Zoric. 2006. The real-time polymerase chain reaction. Mol. Aspects Med. 27:95-125.

98. Kutyavin, I. V., I. A. Afonina, A. Mills, V. V. Gorn, E. A. Lukhtanov, E. S. Belousov, M. J. Singer, D. K. Walburger, S. G. Lokhov, A. A. Gall, R. Dempcy, M. W. Reed, R. B. Meyer, and J. Hedgpeth. 2000. 3'-minor groove binder-DNA probes increase sequence specificity at PCR extension temperatures. Nucleic Acids Res. 28:655-661.

99. LaGier, M. J., L. A. Joseph, T. V. Passaretti, K. A. Musser, and N. M. Cirino. 2004. A realtime multiplexed PCR assay for rapid detection and differentiation of Campylobacter jejuni and Campylobacter coli. Mol. Cell. Probes 18:275-282. 
100. Lastovica, A. J. and B. M. Allos. 2008. Clinical significans of Campylobacter and related species other than Campylobacter jejuni and Campylobacter coli, p. 123-149. In I. Nachamkin, C. M. Szymanski and M. J. Blaser (Eds.), Campylobacter. ASM Press, Washingtin, DC.

101. Lastovica, A. J. and E. le Roux. 2000. Efficient isolation of campylobacteria from stools. J. Clin. Microbiol. 38:2798-2799.

102. Lecos, C. 1986. Of microbes and milk: probing Americas worst Salmonella outbreak. Dairy Food Sanit. 6:136-140.

103. Lee, J. L. and R. E. Levin. 2007. Quantification of total viable bacteria on fish fillets by using ethidium bromide monoazide real-time polymerase chain reaction. Int. J. Food Microbiol. 118:312-317.

104. Lee, J. L. and R. E. Levin. 2006. Use of ethidium bromide monoazide for quantification of viable and dead mixed bacterial flora from fish fillets by polymerase chain reaction. J. Microbiol. Methods 67:456-462.

105. Letertre, C., S. Perelle, F. Dilasser, K. Arar, and P. Fach. 2003. Evaluation of the performance of LNA and MGB probes in 5'-nuclease PCR assays. Mol. Cell. Probes 17:307311.

106. Lin, S., X. Wang, H. Zheng, Z. Mao, Y. Sun, and B. Jiang. 2008. Direct detection of Campylobacter jejuni in human stool samples by real-time PCR. Can. J. Microbiol. 54:742747.

107. Linton, A. H. 1983. Guidelines on prevention and control of salmonellosis. World Health Organization (WHO), Geneva, Switzerland.

108. Löfström, C., R. Knutsson, C. E. Axelsson, and P. Rådstrom. 2004. Rapid and specific detection of Salmonella spp. in animal feed samples by PCR after culture enrichment. Appl. Environ. Microbiol. 70:69-75.

109. Lübeck, P. S., P. Wolffs, S. L. On, P. Ahrens, P. Radstrom, and J. Hoorfar. 2003. Toward an international standard for PCR-based detection of food-borne thermotolerant Campylobacters: assay development and analytical validation. Appl. Environ. Microbiol. 69:5664-5669.

110. Mackay, I. M. 2004. Real-time PCR in the microbiology laboratory. Clin. Microbiol. Infect. 10:190-212.

111. Maddocks, S., T. Olma, and S. Chen. 2002. Comparison of CHROMagar Salmonella medium and xylose-lysine-desoxycholate and Salmonella-Shigella agars for isolation of Salmonella strains from stool samples. J. Clin. Microbiol. 40:2999-3003. 
112. Magistrado, P. A., M. M. Garcia, and A. K. Raymundo. 2001. Isolation and polymerase chain reaction-based detection of Campylobacter jejuni and Campylobacter coli from poultry in the Philippines. Int. J. Food Microbiol. 70:197-206.

113. Malorny, B., C. Löfström, M. Wagner, N. Kramer, and J. Hoorfar. 2008. Enumeration of salmonella bacteria in food and feed samples by real-time PCR for quantitative microbial risk assessment. Appl. Environ. Microbiol. 74:1299-1304.

114. Malorny, B., E. Paccassoni, P. Fach, C. Bunge, A. Martin, and R. Helmuth. 2004. Diagnostic real-time PCR for detection of Salmonella in food. Appl. Environ. Microbiol. 70:7046-7052.

115. Malorny, B., P. T. Tassios, P. Radstrom, N. Cook, M. Wagner, and J. Hoorfar. 2003. Standardization of diagnostic PCR for the detection of foodborne pathogens. Int. J. Food Microbiol. 83:39-48.

116. Malorny, B., D. Made, P. Teufel, C. Berghof-Jager, I. Huber, A. Anderson, and R. Helmuth. 2007. Multicenter validation study of two blockcycler- and one capillary-based real-time PCR methods for the detection of Salmonella in milk powder. Int. J. Food Microbiol. 117:211-218.

117. Medema, G. J., F. M. Schets, A. W. van de Giessen, and A. H. Havelaar. 1992. Lack of colonization of 1 day old chicks by viable, non-culturable Campylobacter jejuni. J. Appl. Bacteriol. 72:512-516.

118. Messens, W., E. Hartnett, X. Gellynck, J. Viaene, D. Halet, L. Herman, and K. Grijspeerdt. 2007. Quantitative risk assessment of human campylobacteriosis through the consumption of chicken meat in Belgium. XVIII European symposium on the quality of poultry meat and XII European symposium on the quality of eggs and egg products: 167-168.

119. Molbak, K., J. E. Olsen, and H. C. Wegener. 2006. Salmonella infections., p. 57-136. In H. P. Riemann and D. O. Cliver (Eds.), Foodborne infections and intoxications. Elsevier Academic Press.

120. Moore, J. E., D. Corcoran, J. S. Dooley, S. Fanning, B. Lucey, M. Matsuda, D. A. McDowell, F. Megraud, B. C. Millar, R. O'Mahony, L. O'Riordan, M. O'Rourke, J. R. Rao, P. J. Rooney, A. Sails, and P. Whyte. 2005. Campylobacter. Vet. Res. 36:351-382.

121. Morales-Rayas, R., P. F. Wolffs, and M. W. Griffiths. 2008. Immunocapture and realtime PCR to detect Campylobacter spp. J. Food Prot. 71:2543-2547.

122. Moreno, Y., M. Hernandez, M. A. Ferrus, J. L. Alonso, S. Botella, R. Montes, and J. Hernandez. 2001. Direct detection of thermotolerant campylobacters in chicken products by PCR and in situ hybridization. Res. Microbiol. 152:577-582. 
123. Mullis, K. B. and F. A. Faloona. 1987. Specific synthesis of DNA in vitro via a polymerase-catalyzed chain reaction. Methods Enzymol. 155:335-350.

124. Myint, M. S., Y. J. Johnson, N. L. Tablante, and R. A. Heckert. 2006. The effect of preenrichment protocol on the sensitivity and specificity of PCR for detection of naturally contaminated Salmonella in raw poultry compared to conventional culture. Food Microbiol. 23:599-604.

125. Nachamkin, I. 1997. Campylobacter jejuni, p. 159-170. In M. P. Doyle, L. R. Beuchat and T. J. Montville (Eds.), Food Microbiology. Fundamentals and Frontiers. ASM Press, Washington D.C.

126. Nebe-von-Caron, G., P. J. Stephens, C. J. Hewitt, J. R. Powell, and R. A. Badley. 2000. Analysis of bacterial function by multi-colour fluorescence flow cytometry and single cell sorting. J. Microbiol. Methods 42:97-114.

127. Neimann, J., J. Engberg, K. Molbak, and H. C. Wegener. 2003. A case-control study of risk factors for sporadic campylobacter infections in Denmark. Epidemiol. Infect. 130:353366.

128. Nocker, A. and A. K. Camper. 2006. Selective removal of DNA from dead cells of mixed bacterial communities by use of ethidium monoazide. Appl. Environ. Microbiol. 72:19972004.

129. Nocker, A., C. Y. Cheung, and A. K. Camper. 2006. Comparison of propidium monoazide with ethidium monoazide for differentiation of live vs. dead bacteria by selective removal of DNA from dead cells. J. Microbiol. Methods 67:310-320.

130. Nogva, H. K., S. M. Dromtorp, H. Nissen, and K. Rudi. 2003. Ethidium monoazide for DNA-based differentiation of viable and dead bacteria by 5'-nuclease PCR. BioTechniques 34:804-8, 810, 812-3.

131. Nogva, H. K., A. Bergh, A. Holck, and K. Rudi. 2000. Application of the 5'-nuclease PCR assay in evaluation and development of methods for quantitative detection of Campylobacter jejuni. Appl. Environ. Microbiol. 66:4029-4036.

132. Oliveira, T. C., S. Barbut, and M. W. Griffiths. 2005. A robotic DNA purification protocol and real-time PCR for the detection of Campylobacter jejuni in foods. J. Food Prot. 68:21312135.

133. Oliveira, T. C., S. Barbut, and M. W. Griffiths. 2005. Detection of Campylobacter jejuni in naturally contaminated chicken skin by melting peak analysis of amplicons in real-time PCR. Int. J. Food Microbiol. 104:105-111. 
134. Olson, K. C., S. Ethelberg, W. Van Pelt, and V. Tauxe. 2008. Epidemiology of Campylobacter jejuni infections in industrialized nations, p. 163-189. In I. Nachamkin, C. M. Szymanski and M. J. Blaser (Eds.), Campylobacter. ASM Press, Washington DC.

135. Pan, Y. and F. Breidt Jr. 2007. Enumeration of viable Listeria monocytogenes cells by real-time PCR with propidium monoazide and ethidium monoazide in the presence of dead cells. Appl. Environ. Microbiol. 73:8028-8031.

136. Pang, T., Z. A. Bhutta, B. B. Finlay, and M. Altwegg. 1995. Typhoid fever and other salmonellosis: a continuing challenge. Trends Microbiol. 3:253-255.

137. Park, R. W., P. L. Griffiths, and G. S. Moreno. 1991. Sources and survival of campylobacters: relevance to enteritis and the food industry. Soc. Appl. Bacteriol. Symp. Ser. 20:97S-106S.

138. Park, S. F. 2002. The physiology of Campylobacter species and its relevance to their role as foodborne pathogens. Int. J. Food Microbiol. 74:177-188.

139. Parkhill, J., B. W. Wren, K. Mungall, J. M. Ketley, C. Churcher, D. Basham, T. Chillingworth, R. M. Davies, T. Feltwell, S. Holroyd, K. Jagels, A. V. Karlyshev, S. Moule, M. J. Pallen, C. W. Penn, M. A. Quail, M. A. Rajandream, K. M. Rutherford, A. H. van Vliet, S. Whitehead, and B. G. Barrell. 2000. The genome sequence of the food-borne pathogen Campylobacter jejuni reveals hypervariable sequences. Nature 403:665-668.

140. Perelle, S., M. Josefsen, J. Hoorfar, F. Dilasser, J. Grout, and P. Fach. 2004. A LightCycler real-time PCR hybridization probe assay for detecting food-borne thermophilic Campylobacter. Mol. Cell. Probes 18:321-327.

141. Perez, J. M., P. Cavalli, C. Roure, R. Renac, Y. Gille, and A. M. Freydiere. 2003. Comparison of four chromogenic media and Hektoen agar for detection and presumptive identification of Salmonella strains in human stools. J. Clin. Microbiol. 41:1130-1134.

142. Persing, D. H. 1993. In vitro nucleic acid amplification techniques. In D. H. Persing, F. T. Smith, F. C. Tenover and T. J. White (Eds.), Diagnostic molecular microbiology. Principles and applications. Mayo Foundation, US.

143. Rådstrom, P., R. Knutsson, P. Wolffs, M. Lovenklev, and C. Löfström. 2004. Pre-PCR processing: strategies to generate PCR-compatible samples. Mol. Biotechnol. 26:133-146.

144. Rahn, K., S. A. De Grandis, R. C. Clarke, S. A. McEwen, J. E. Galan, C. Ginocchio, R. Curtiss 3rd, and C. L. Gyles. 1992. Amplification of an invA gene sequence of Salmonella typhimurium by polymerase chain reaction as a specific method of detection of Salmonella. Mol. Cell. Probes 6:271-279. 
145. Reynisson, E., M. H. Josefsen, M. Krause, and J. Hoorfar. 2006. Evaluation of probe chemistries and platforms to improve the detection limit of real-time PCR. J. Microbiol. Methods 66:206-216.

146. Rollins, D. M. and R. R. Colwell. 1986. Viable but nonculturable stage of Campylobacter jejuni and its role in survival in the natural aquatic environment. Appl. Environ. Microbiol. 52:531-538.

147. Ronner, A. C. and H. Lindmark. 2007. Quantitative detection of Campylobacter jejuni on fresh chicken carcasses by real-time PCR. J. Food. Prot. 70:1373-1378.

148. Rosenquist, H., N. L. Nielsen, H. M. Sommer, B. Norrung, and B. B. Christensen. 2003. Quantitative risk assessment of human campylobacteriosis associated with thermophilic Campylobacter species in chickens. Int. J. Food Microbiol. 83:87-103.

149. Rossen, L., P. Norskov, K. Holmstrom, and O. F. Rasmussen. 1992. Inhibition of PCR by components of food samples, microbial diagnostic assays and DNA-extraction solutions. Int. J. Food Microbiol. 17:37-45.

150. Rudi, K., K. Naterstad, S. M. Dromtorp, and H. Holo. 2005. Detection of viable and dead Listeria monocytogenes on gouda-like cheeses by real-time PCR. Lett. Appl. Microbiol. 40:301-306.

151. Rudi, K., B. Moen, S. M. Dromtorp, and A. L. Holck. 2005. Use of ethidium monoazide and PCR in combination for quantification of viable and dead cells in complex samples. Appl. Environ. Microbiol. 71:1018-1024.

152. Rueckert, A., R. S. Ronimus, and H. W. Morgan. 2005. Rapid differentiation and enumeration of the total, viable vegetative cell and spore content of thermophilic bacilli in milk powders with reference to Anoxybacillus flavithermus. J. Appl. Microbiol. 99:1246-1255.

153. Sails, A. D., F. J. Bolton, A. J. Fox, D. R. Wareing, and D. L. Greenway. 1998. A reverse transcriptase polymerase chain reaction assay for the detection of thermophilic Campylobacter spp. Mol. Cell. Probes 12:317-322.

154. Sails, A. D., A. J. Fox, F. J. Bolton, D. R. A. Wareing, and D. L. A. Greenway. 2003. A real-time PCR assay for the detection of Campylobacter jejuni in foods after enrichment culture. Appl. Environ. Microbiol. 69:1383-1390.

155. Schuurman, T., A. van Breda, R. de Boer, M. Kooistra-Smid, M. Beld, P. Savelkoul, and R. Boom. 2005. Reduced PCR sensitivity due to impaired DNA recovery with the MagNA Pure LC total nucleic acid isolation kit. J. Clin. Microbiol. 43:4616-4622. 
156. Schuurman, T., T. d. Boer, E. v. Zanten, K. R. v. Slochteren, H. R. Scheper, B. G. DijkAlberts, A. V. M. Moeller, and A. M. D. Kooistra-Smid. 2007. Feasibility of a molecular screening method for detection of Salmonella enterica and Campylobacter jejuni in a routine community-based clinical microbiology laboratory. J. Clin. Microbiol. 45:3692-3700

157. Singer, R. S., A. E. Mayer, T. E. Hanson, and R. E. Isaacson. 2009. Do microbial interactions and cultivation media decrease the accuracy of Salmonella surveillance systems and outbreak investigations? J. Food Prot. 72:707-713.

158. Smibert, R. M. 1984. Genus III. Campylobacter, p. 111-118. In N. R. Krieg, D. H. Bergey and J. G. Holt (Eds.), Bergey's Manual of Systematic Bacteriology, vol. 1. Williams and Wilkins, Baltimore, USA.

159. Soejima, T., K. lida, T. Qin, H. Taniai, M. Seki, and S. Yoshida. 2008. Method To Detect Only Live Bacteria during PCR Amplification. J. Clin. Microbiol. 46:2305-2313.

160. Soejima, T., K. lida, T. Qin, H. Taniai, M. Seki, A. Takade, and S. Yoshida. 2007. Photoactivated ethidium monoazide directly cleaves bacterial DNA and is applied to PCR for discrimination of live and dead bacteria. Microbiol. Immunol. 51:763-775.

161. Solinas, A., L. J. Brown, C. McKeen, J. M. Mellor, J. Nicol, N. Thelwell, and T. Brown. 2001. Duplex Scorpion primers in SNP analysis and FRET applications. Nucleic Acids Res. 29:E96.

162. Stern, N. J. 1992. Reservoirs for Campylobacter jejuni and approaches for intervention in poultry, p. 49. In I. Nachamkin, M. J. Blaser and L. S. Tompkins (Eds.), Campylobacter jejuni. Current Status and Future Trends. ASM Press, Washington, D.C.

163. Stern, N. J. and S. Pretanik. 2006. Counts of Campylobacter spp. on U.S. broiler carcasses. J. Food Prot. 69:1034-1039.

164. Stolz, J. F., R. S. Oremland, B. J. Paster, F. E. Dewhirst, and P. Vandamme. 2005. Genus III. Sulfospirillum, p. 1165-1168. In D. J. Brenner, N. R. Krieg, J. T. Staley and G. M. Garrity (Eds.), Bergey's Manual of Systematic Bacteriology, vol. 2. Springer-Verlag, New York.

165. Taylor, G. R. 1991. Polymerase chain reaction: basic principles and automation. In M. J. McPherson, P. Quirke and G. R. Taylor (Eds.), PCR. A practical approach. Oxford University Press, UK.

166. Thelwell, N., S. Millington, A. Solinas, J. Booth, and T. Brown. 2000. Mode of action and application of Scorpion primers to mutation detection. Nucleic Acids Res. 28:3752-3761.

167. Thomas, L. V., J. W. Wimpenny, and A. C. Peters. 1992. Testing multiple variables on the growth of a mixed inoculum of Salmonella strains using gradient plates. Int. J. Food Microbiol. 15:165-175. 
168. Thomason, B. M., D. J. Dodd, and W. B. Cherry. 1977. Increased recovery of salmonellae from environmental samples enriched with buffered peptone water. Appl. Environ. Microbiol. 34:270-273.

169. Tietjen, M. and D. Y. Fung. 1995. Salmonellae and food safety. Crit. Rev. Microbiol. 21:53-83.

170. Todd, E. C. D. 1997. Epidemiology of foodborne diseases: a worldwide review. World Health Stat Q 50:30-50.

171. Uzzau, S., D. J. Brown, T. Wallis, S. Rubino, G. Leori, S. Bernard, J. Casadesus, D. J. Platt, and J. E. Olsen. 2000. Host adapted serotypes of Salmonella enterica. Epidemiol. Infect. 125:229-255.

172. Valasek, M. A. and J. J. Repa. 2005. The power of real-time PCR. Adv. Physiol. Educ. 29:151-159.

173. van der Zee, H. and J. H. J. Huis in't Veld. 2000. Methods for the rapid detection of Salmonella., p. 373. In C. Wray and A. Wray (Eds.), Salmonella in domestic animals. Cabi Publishing, Wallingford, UK.

174. van Dijk, S., M. J. Bruins, and G. J. Ruijs. 2009. Evaluation and implementation of a chromogenic agar medium for salmonella detection in stool in routine laboratory diagnostics. J. Clin. Microbiol. 47:456-458.

175. van Schothorst, M., R. J. Gilbert, R. W. Harvey, O. Pietzsch, and E. H. Kampelmacher. 1978. Comparative studies on the isolation of salmonella from minced meat. Zentralbl. Bakteriol. B. 167:138-145.

176. Vandamme, P. 2000. Taxonomy of the Family Campylobacteraceae, p. 3. In I. Nachamkin and M. J. Blaser (Eds.), Campylobacter. ASM Press, Washington, D.C.

177. Varadaraj, K. and D. M. Skinner. 1994. Denaturants or cosolvents improve the specificity of PCR amplification of a $G+C$-rich DNA using genetically engineered DNA polymerases. Gene 140:1-5.

178. Vellinga, A. and F. Van Loock. 2002. The dioxin crisis as experiment to determine poultry-related campylobacter enteritis. Emerg. Infect. Dis. 8:19-22.

179. Walsh, P. S., D. A. Metzger, and R. Higuchi. 1991. Chelex 100 as a medium for simple extraction of DNA for PCR-based typing from forensic material. BioTechniques 10:506-513.

180. Waltman, W. D. 2000. Methods for cultural isolation of Salmonella, p. 355. In C. Wray and A. Wray (ed.), Salmonella in domestic animals. Cabi Publishing, Wallingford, UK. 
181. Wang, R. F., W. W. Cao, and M. G. Johnson. 1992. 16S rRNA-based probes and polymerase chain reaction method to detect Listeria monocytogenes cells added to foods. Appl. Environ. Microbiol. 58:2827-2831.

182. Wang, S. and R. E. Levin. 2006. Discrimination of viable Vibrio vulnificus cells from dead cells in real-time PCR. J. Microbiol. Methods 64:1-8.

183. Wassenaar, T. M. and D. G. Newell. 2006. The Genus Campylobacter, p. 119-138. In The Prokariots, vol. 7. Springer, New York.

184. Wassenaar, T. M. and M. J. Blaser. 1999. Pathophysiology of Campylobacter jejuni infections of humans. Microbes Infect. 1:1023-1033.

185. Whitcombe, D., J. Theaker, S. P. Guy, T. Brown, and S. Little. 1999. Detection of PCR products using self-probing amplicons and fluorescence. Nat. Biotechnol. 17:804-807.

186. Wilson, I. G. 1997. Inhibition and facilitation of nucleic acid amplification. Appl. Environ. Microbiol. 63:3741-3751.

187. Winfield, M. D. and E. A. Groisman. 2003. Role of nonhost environments in the lifestyles of Salmonella and Escherichia coli. Appl. Environ. Microbiol. 69:3687-3694.

188. Wolffs, P., B. Norling, and P. Radstrom. 2005. Risk assessment of false-positive quantitative real-time PCR results in food, due to detection of DNA originating from dead cells. J. Microbiol. Methods 60:315-323.

189. Wolffs, P., H. Grage, O. Hagberg, and P. Radstrom. 2004. Impact of DNA polymerases and their buffer systems on quantitative real-time PCR. J. Clin. Microbiol. 42:408-411.

190. Wolffs, P., B. Norling, J. Hoorfar, M. Griffiths, and P. Radstrom. 2005. Quantification of Campylobacter spp. in chicken rinse samples by using flotation prior to real-time PCR. Appl. Environ. Microbiol. 71:5759-5764.

191. Yang, C., Y. Jiang, K. Huang, C. Zhu, and Y. Yin. 2003. Application of real-time PCR for quantitative detection of Campylobacter jejuni in poultry, milk and environmental water. FEMS Imm. Med. Microbiol. 38:265-271.

192. Young, K. T., L. M. Davis, and V. J. Dirita. 2007. Campylobacter jejuni: molecular biology and pathogenesis. Nat. Rev. Microbiol. 5:665-679.

193. Ziprin, R. L. and R. B. Harvey. 2004. Inability of cecal microflora to promote reversion of viable nonculturable Campylobacter jejuni. Avian Dis. 48:647-650.

194. Ziprin, R. L., R. E. Droleskey, M. E. Hume, and R. B. Harvey. 2003. Failure of viable nonculturable Campylobacter jejuni to colonize the cecum of newly hatched leghorn chicks. Avian Dis. 47:753-758. 
Towards an international standard for PCR-based detection of foodborne thermotolerant campylobacters: interaction of enrichment media and pre-PCR treatment on carcass rinse samples. Josefsen, M.H., P.S. Lubeck, F. Hansen, and J. Hoorfar.

Journal of Microbiological Methods (2004) 58:39-48. 


\title{
Towards an international standard for PCR-based detection of foodborne thermotolerant campylobacters: interaction of enrichment media and pre-PCR treatment on carcass rinse samples
}

\author{
M.H. Josefsen ${ }^{\text {a }}$, P.S. Lübeck ${ }^{a}$, F. Hansen ${ }^{b}$, J. Hoorfar ${ }^{a, *}$ \\ ${ }^{a}$ Danish Institute for Food and Veterinary Research (DFVF), 27 Bülowsvej, DK-1790 Copenhagen V, Denmark \\ ${ }^{\mathrm{b}}$ Danish Meat Research Institute, 2 Maglegaardsvej, DK-4000 Roskilde, Denmark
}

Received 30 October 2003; received in revised form 16 February 2004; accepted 1 March 2004

Available online 14 April 2004

\begin{abstract}
As part of a large EU project for standardisation of polymerase chain reaction (PCR), a systematic evaluation of the interaction of enrichment media, type of DNA polymerase and pre-PCR sample treatment for a PCR detecting thermotolerant campylobacters was carried out. The growth-supporting capacity and PCR compatibility of enrichment in Preston, Mueller-Hinton and Bolton broth (blood-containing and blood-free) were evaluated. The effect of resin-based DNA extraction and DNA extraction by boiling on the final PCR assay was investigated. The time-course studies indicated that a 20-h sample enrichment in blood-containing Bolton broth, followed by a simple resin-based extraction of DNA and a PCR amplification using Tth polymerase, resulted in strong and clear PCR amplicons for target (287 bp) and internal amplification control (IAC, 124 bp). The enrichment PCR-based method, tested on 68 presumably naturally contaminated poultry-rinse samples, showed a diagnostic sensitivity of $97.5 \%$ (39 PCR-positive/40 total positive samples) and a diagnostic specificity of 100\% (28 PCR-negative/28 total negative samples; $P=0.32$ ) when compared to a standard bacteriological method (ISO 10272).
\end{abstract}

(C) 2004 Elsevier B.V. All rights reserved.

Keywords: Campylobacter; PCR; Enrichment; Carcass rinse; Food

\section{Introduction}

Thermotolerant Campylobacter, particularly Campylobacter jejuni and Campylobacter coli, are presently the most common causes of human foodborne infections in several developed countries where the number of reported cases of campylobacteriosis by far

\footnotetext{
* Corresponding author. Tel.: +45-72346251; fax: +4572346001 .

E-mail address: jho@dfvf.dk (J. Hoorfar).
}

has exceeded the number of cases of salmonellosis (Altekruse et al., 1999; Friedman et al., 2000). Despite a low fatality rate associated with campylobacteriosis, the personal distress and the economic impact in form of medical visits, medication, hospitalisation, and loss of productivity is extensive (Friedman et al., 2000). This emphasises the importance of efficient and reliable detection methods in food and in the food production chain.

Several non-commercial and open-formula polymerase chain reaction (PCR)-based detection meth- 
ods have been described, using various sample types, enrichment media and primer sets (Denis et al., 2001; Englen and Kelley, 2000; Giesendorf and Quint, 1995; Magistrado et al., 2001; Moreno et al., 2001; Ng et al., 1997; O'Sullivan et al., 2000; Waage et al., 1999; Wang et al., 1999; Winters et al., 1997). However, none of them included an internal amplification control (IAC) and none were assessed in collaborative trials, which is the approach of the present study. The lack of proper validation and standardised protocols has hampered the implementation of PCR-based methods by enduser laboratories (Hoorfar and Cook, 2002). In addition, no systematic evaluation is, to our knowledge, available on the interaction of Campylobacter enrichment media and pre-PCR treatment on carcass rinse samples, which was the focus of the present study.

The final PCR-based method, including an IAC, was compared with the traditional culture-based method on potentially naturally contaminated chickenrinse samples. The PCR-based detection method reported here was subsequently validated in a large international multi-centre collaborative trial (Josefsen et al., manuscript submitted).

\section{Materials and methods}

\subsection{Preparation of media}

Preston broth (PB) was prepared essentially according to ISO 10272 (Anonymous, 1995). Bolton broth $(\mathrm{BB})$ broth was prepared according to the recommendations of the Bacteriological Analytical Manual Online (Hunt et al., 1998). Mueller-Hinton broth (MHB) was prepared from $21 \mathrm{~g}$ of Bacto MHB (Difco, Detroit, USA), $0.25 \mathrm{~g}$ of pyruvic acid (Sigma), $0.25 \mathrm{~g}$ of sodium bisulphite (Sigma) and $0.25 \mathrm{~g}$ of iron sulphate (Sigma) dissolved in $1000 \mathrm{ml}$ of distilled water. The broth was autoclaved at $121{ }^{\circ} \mathrm{C}$ for $15 \mathrm{~min}$ and the following antibiotics were added aseptically: sodium cefoperazone $(30 \mathrm{mg} / \mathrm{l}$, Sigma) and trimethoprim lactate $(50 \mathrm{mg} / \mathrm{l}$, Sigma). The blood agar (Oxoid), the modified charcoal cefoperazone deoxycholate agar (mCCDA, Oxoid) and the Preston agar (Oxoid) were prepared according to the manufacturer's instructions.

\subsection{DNA extraction}

\subsubsection{Resin-based extraction}

The resin-based extraction was performed essentially as described by Walsh et al. (1991) and modified by Malorny et al. (2003). In brief, $1 \mathrm{ml}$ enriched broth sample (Experiments 2-4) was centrifuged for $5 \mathrm{~min}$ at $10,000 \times g$ at $4{ }^{\circ} \mathrm{C}$. The pellet was resuspended in 300 $\mu \mathrm{l}$ of $6 \%$ Chelex 100 resin suspension (Bio-Rad Laboratories, CA, USA) and incubated for $20 \mathrm{~min}$ in a 56 ${ }^{\circ} \mathrm{C}$ water bath. The sample was vortexed for $10 \mathrm{~s}$ and incubated in a $100{ }^{\circ} \mathrm{C}$ water bath for $8 \mathrm{~min}$, followed by immediate chilling on ice. The sample was centrifuged for $5 \mathrm{~min}$ at $14,000 \times g$ at $4{ }^{\circ} \mathrm{C}$ and $5 \mu \mathrm{l}$ of the supernatant was used as template in the PCR assay.

\subsection{Extraction by boiling}

One milliliter enriched sample (Experiment 2) was centrifuged for $5 \mathrm{~min}$ at $10,000 \times g$ at $4{ }^{\circ} \mathrm{C}$ and pellet was resuspended in $1 \mathrm{ml}$ physiological saline. The sample was centrifuged again for $5 \mathrm{~min}$ at $10,000 \times \mathrm{g}$ at $4{ }^{\circ} \mathrm{C}$ and the pellet was resuspended in $100 \mu \mathrm{TE}$ buffer (10 mM Tris, $0.1 \mathrm{mM}$ EDTA, $\mathrm{pH}$ 8). The sample was incubated in a $100{ }^{\circ} \mathrm{C}$ water bath for 10 min. After a final centrifugation $(5 \mathrm{~min}$ at $10,000 \times \mathrm{g}$ at $\left.4{ }^{\circ} \mathrm{C}\right), 5 \mu \mathrm{l}$ of the supernatant was used as template in the PCR assay.

\subsubsection{Untreated broth}

Five microliters of untreated enriched broth was used as template in the PCR assay.

\subsection{PCR conditions}

The PCR procedure was based on amplification of a 287-bp sequence of the 16S rRNA gene of $C$. jejuni, $C$. coli and Campylobacter lari, and an IAC of $124 \mathrm{bp}$ (Lübeck et al., 2003a,b). PCR amplifications were carried out in $25 \mu \mathrm{l}$ mixtures, each consisting of 2.5 $\mu 110 \times$ PCR buffer for Tth DNA polymerase (Roche Applied Science, Hvidovre, Denmark), $1 \mathrm{U}$ Tth DNA polymerase (Roche Applied Science), $0.4 \mathrm{mM}$ dNTP nucleotide mixture (Amersham Pharmacia Biotech, Buckinghamshire, UK), 11 pmol forward primer OT 1559 (CTG CTT AAC ACA AGT TGA GTA GG; Lübeck et al., 2003a), 12 pmol reverse primer 18-1 (TTC CTT AGG TAC CGT CAG AA; Lübeck et al., 
2003a), $5 \mu \mathrm{g}$ bovine serum albumin (BSA; Roche Applied Science) and $50 \mu \mathrm{mol} \mathrm{MgCl}_{2}$ (Applied Biosystems, Nærum, Denmark). Each reaction tube was added with $5 \mu 1$ sample containing template DNA. The PCR amplifications were performed in a GeneAmp ${ }^{\circledR}$ PCR Systems 9700 (Perkin Elmer Applied Biosystems, Norwalk, USA) in 0.2-ml thermo-strips (ABgene House, Surrey, UK). Amplification conditions were primary denaturation at $94{ }^{\circ} \mathrm{C}$ for $2 \mathrm{~min}$, followed by 35 cycles consisting of denaturation at $94{ }^{\circ} \mathrm{C}$ for $30 \mathrm{~s}$, annealing at $58{ }^{\circ} \mathrm{C}$ for $15 \mathrm{~s}$ and extension at $72{ }^{\circ} \mathrm{C}$ for $30 \mathrm{~s}$. A final step of $4 \mathrm{~min}$ at $72{ }^{\circ} \mathrm{C}$ was included to ensure full extension of the products. A negativecontrol-added $5 \mu 1$ PCR-grade water was included in each run. A positive PCR result was accepted if a correct-sized band was present. A negative PCR result was accepted only if an IAC band was present.

\subsection{Experimental design}

Table 1 shows the outline of the experimental design. All incubations were carried out at $42.0 \pm 1.0$ ${ }^{\circ} \mathrm{C}$ under microaerobic conditions $\left(6 \% \mathrm{O}_{2}, 7 \% \mathrm{CO}_{2}\right.$, $7 \% \mathrm{H}_{2}$ and $80 \% \mathrm{~N}_{2}$ ), unless stated otherwise.

The number of colony forming units (CFU) in cultures was determined by spreading $100 \mu \mathrm{l}$ of 10 fold serial dilutions onto blood agar, incubating the agar plates for $24 \mathrm{~h}$ and counting them, unless stated otherwise.

\subsubsection{Experiment 1: selection of enrichment broth}

The growth of different strains of $C$. jejuni, $C$. coli and $C$. lari in $\mathrm{PB}, \mathrm{MHB}$ and blood-free $\mathrm{BB}$ was examined.
The following Campylobacter strains were plated onto blood agar and incubated for $24 \mathrm{~h}$ : C. jejuni strains-Culture Collection University of Göteborg (CCUG) 10935, CCUG 10936, CCUG 10937, CCUG 10938, and 1677; C. coli strains-CCUG 10939, CCUG 15360, CCUG 10960, CCUG 11283 and 3931; and C. lari strains-CCUG 22395, CCUG 20707, CCUG 23947, CCUG 12774, and 98-40052. From the agar plates, overnight cultures were made in $\mathrm{PB}, \mathrm{MHB}$ or $\mathrm{BB}$, respectively. $\mathrm{PB}, \mathrm{MHB}$ or $\mathrm{BB}$ were spiked with 100-1000 CFU/10 ml C. jejuni, C. coli or C. lari from the appropriate overnight culture and incubated. The growth was monitored over a period of $24 \mathrm{~h}$, by spreading 10 -fold serial dilutions onto blood agar after $0,4,10$ or $24 \mathrm{~h}$ of enrichment.

\subsubsection{Experiment 2: spiked samples}

The purpose of the experiment was to evaluate the growth and PCR detection of $C$. jejuni 1677 and $C$. coli 3931 in $\mathrm{PB}, \mathrm{MHB}$ and blood-free $\mathrm{BB}$ when chicken-rinse or pork swab-rinse was added. C. jejuni 1677 and C. coli 3931 were chosen as they are among the most frequently isolated thermotolerant campylobacters from poultry and pork, respectively, in Denmark. At the same time, the ability of the three enrichment media to suppress background flora was investigated. C. jejuni 1677 or C. coli 3931 were inoculated into $10 \mathrm{ml}$ of $\mathrm{PB}, \mathrm{MHB}$ or blood-free $\mathrm{BB}$, respectively, and incubated overnight. Two milliliters of chicken-rinse or pork swab-rinse was added to 18 $\mathrm{ml}$ of $\mathrm{PB}, \mathrm{MHB}$ or blood-free BB. The chicken-rinse was prepared as recommended by ISO/CD 6887 (Anonymous, 2000), by washing a whole chicken in $500 \mathrm{ml}$ of cold $\left(4{ }^{\circ} \mathrm{C}\right)$ physiological saline for $60 \mathrm{~s}$

Table 1

Outline of the experimental design for interaction of media and sample treatment for PCR-based detection of thermotolerant campolybacters

\begin{tabular}{|c|c|c|c|c|c|c|c|c|c|}
\hline \multirow[t]{2}{*}{ Experiment number } & \multicolumn{2}{|l|}{ Sample type } & \multicolumn{4}{|c|}{ Enrichment broth } & \multicolumn{3}{|c|}{ Inoculation strain } \\
\hline & Chicken-rinse & $\begin{array}{l}\text { Pork } \\
\text { swab-rinse }\end{array}$ & $\mathrm{PB}$ & MHB & $\begin{array}{l}\text { BB including } \\
\text { blood }\end{array}$ & $\begin{array}{l}\text { BB not } \\
\text { including blood }\end{array}$ & C. jejuni & C. coli & C. lari \\
\hline $\begin{array}{l}\text { 1. Selection of } \\
\text { enrichment broth }\end{array}$ & & & $\times$ & $\times$ & & $\times$ & $\times$ & $\times$ & $\times$ \\
\hline 2. Spiked samples & $\times$ & $\times$ & $\times$ & $\times$ & & $x$ & $\times$ & $\times$ & \\
\hline $\begin{array}{l}\text { 3. Optimisation of } \\
\text { enrichment time }\end{array}$ & $\times$ & $\times$ & & & $\times$ & & $\times$ & $x$ & \\
\hline $\begin{array}{l}\text { 4. Naturally contaminated } \\
\text { samples }\end{array}$ & $\times$ & & & & $\times$ & & & & \\
\hline
\end{tabular}

$\times$ : Included in the experiment; PB: Preston broth; MHB: Mueller-Hinton broth; BB: Bolton broth. 
(Josefsen et al., 2002). The pork swabs, sampled in accordance with ISO/FDIS 17604 (Anonymous, 2003), by swabbing pork carcass areas of $1400 \mathrm{~cm}^{2}$ with sterile gauze swabs $(10 \times 10 \mathrm{~cm}$; Smith \& Nephew, Nærum, Denmark), were obtained from the Danish Meat Research Institute. A total of $100 \mathrm{ml}$ of cold $\left(4{ }^{\circ} \mathrm{C}\right)$ physiological saline was added to a stomacher bag containing the pork swab, and it was shaken and rubbed by hand for $60 \mathrm{~s}$. By cutting the corner of the stomacher bag, the pork swab-rinse was transferred to a sterile bottle. The broths were spiked with $0,1-10,10-100$ and $100-1000 \mathrm{CFU} C$. jejuni 1677 or $C$. coli 3931 from the appropriate overnight culture and incubated. The growth was monitored over $24 \mathrm{~h}$ by spreading 10 -fold serial dilutions onto mCCDA after $0,4,10$ or $24 \mathrm{~h}$ of enrichment. At the beginning and the end of enrichment, $100 \mu \mathrm{l}$ were spread onto blood agar to assess the level of background flora. Samples for PCR amplification were drawn after $0,4,10$ or $24 \mathrm{~h}$ of enrichment. PCR was performed on untreated enrichment broth, on DNA extracted by the resin-based method and on DNA extracted by boiling (Fig. 1).

\subsubsection{Experiment 3: optimisation of enrichment time}

In order to find the shortest time of enrichment necessary for PCR detection, the growth of $C$. jejuni 1677 and C. coli 3931 in blood-containing BB, to which chicken-rinse or pork swab-rinse was added, was examined over time. C. jejuni 1677 or C. coli 3931 was inoculated into $10 \mathrm{ml}$ of blood-containing BB and incubated overnight. To $18 \mathrm{ml}$ of blood-containing BB was added either $2 \mathrm{ml}$ of chicken-rinse or $2 \mathrm{ml}$ of pork swab-rinse, and they were spiked with $0,1-10,10$ 100 and 100-1000/20 $\mathrm{ml} \mathrm{CFU} \mathrm{C.} \mathrm{jejuni} 1677$ or C. coli 3931 from the overnight culture and incubated. The growth was monitored over a period of $24 \mathrm{~h}$ by spreading 10-fold serial dilutions onto mCCDA and blood agar after $0,12,18$ or $24 \mathrm{~h}$ of enrichment. Samples for PCR amplification were drawn at $0 \mathrm{~h}$, and after 12, 14, 16, 18, 20, 22 or $24 \mathrm{~h}$ of enrichment. PCR was performed on untreated enrichment broth and on DNA extracted by the resin-based method (Fig. 2).

The effect of an undefined background flora on the growth of C. jejuni 1677 and C. coli 3931 was investigated. Chicken-rinse was plated on to blood agar and incubated at $37.0 \pm 1.0$ and $42.0 \pm 1.0{ }^{\circ} \mathrm{C}$

\section{Spiking culture}

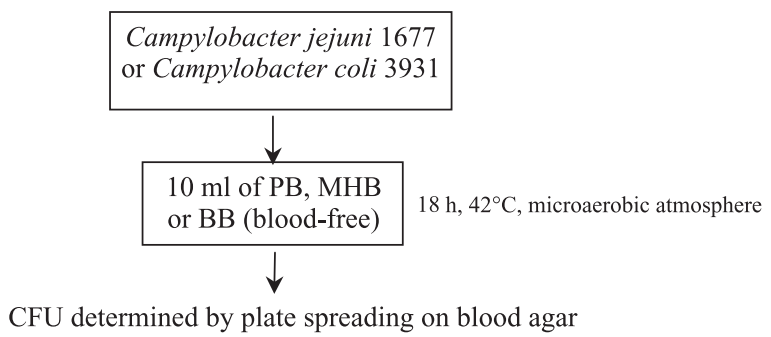

Spiked samples

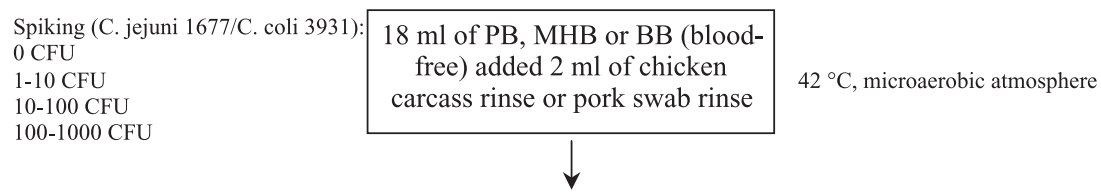

The growth of thermotolerant campylobacters was monitored by plate spreading on mCCDA after $0,4,10$ or $24 \mathrm{~h}$ of incubation.

1-ml samples for PCR amplification were drawn after $0,4,10$ or $24 \mathrm{~h}$ of incubation.

Fig. 1. Flow diagram of the protocol of Experiment 2 on spiked chicken-rinse samples. PB: Preston broth; MHB: Mueller-Hinton broth; BB: Bolton broth. 


\section{Spiking culture}
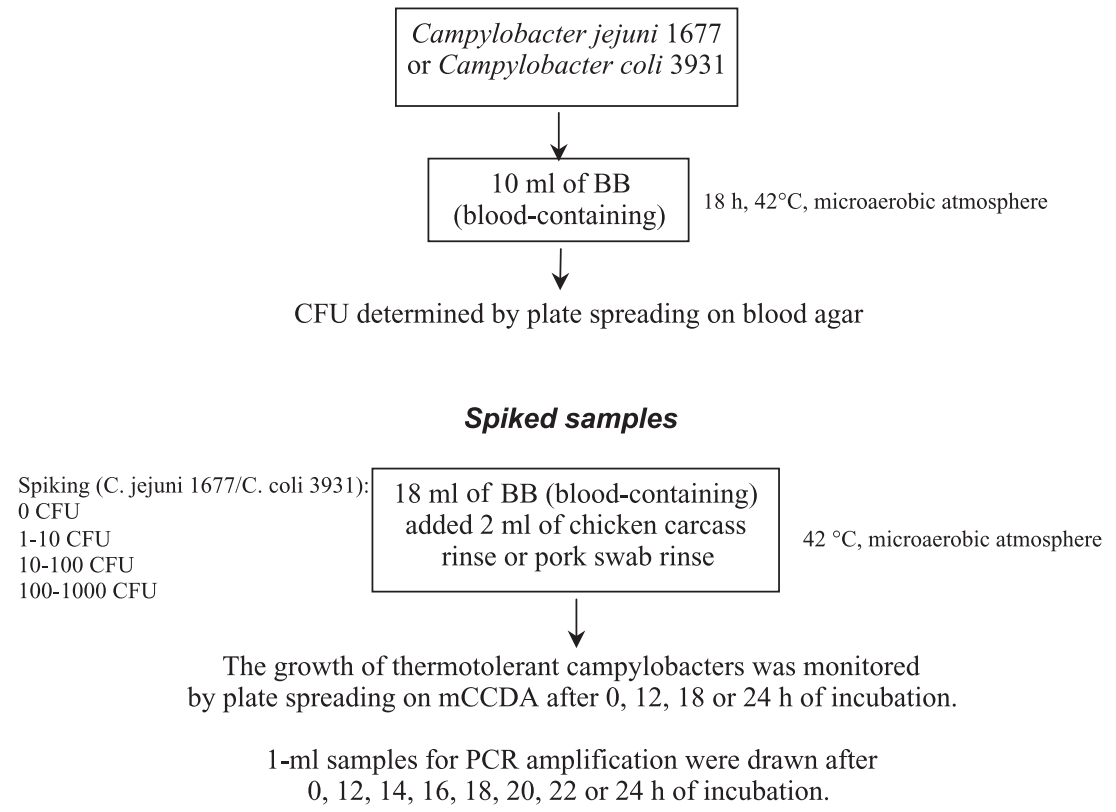

Fig. 2. Flow diagram of the protocol of Experiment 3 for optimisation of enrichment time. PB: Preston broth; MHB: Mueller-Hinton broth; BB: Bolton broth.

under aerobic conditions for $24 \mathrm{~h}$. A suspension of this growth on the agar plates was made in physiological saline and $>10^{5}$ CFU (total aerobic bacteria) was inoculated into samples spiked with 0 and $100-$ 1000/20 ml CFU C. jejuni 1677 and C. coli 3931, respectively.

\subsubsection{Experiment 4: naturally contaminated samples}

In order to compare the performance of the final PCR-based protocol with a standard culture-based method, 66 chickens and 2 ducks were tested, employing both methods. A total of 66 chickens, including 26 Danish and 40 French (imported) freerange or intensively reared chickens and two ducks (Denmark), were purchased on six different occasions from local retailers. The poultry-rinse was prepared as described in Experiment 2, except for the ducks that were rinsed in $1000 \mathrm{ml}$ of saline. Twenty-five milliliters of the poultry-rinse was transferred to $225 \mathrm{ml}$ of blood-containing BB and incubated for $20 \mathrm{~h}$. A 10fold dilution series was made and $100 \mu \mathrm{l}$ of this spread on to mCCDA and Preston agar in the concentrations $10^{-1}, 10^{-2}, 10^{-3}, 10^{-4}$ and $10^{-5}$. The agar plates were incubated for $48 \mathrm{~h}$. Five typical colonies from each poultry-rinse were verified by applying the following tests: Gram reaction by the KOH 3\% method, oxidase test, catalase test and by microscopic inspection of motility and morphology (Josefsen et al., 2002). DNA was extracted by the resin-based method from $1 \mathrm{ml}$ enrichment and examined by PCR.

\subsubsection{Data analysis}

The PCR-based method was compared to the culture-based method by performing McNemar's test (Siegel and Castellan, 1988). McNemar's test was used to analyse the non-independent paired samples in order to determine the agreement or difference between the two methods.

\section{Results}

\subsection{Selection of enrichment media}

All three enrichment media supported the growth of the five C. jejuni strains tested equally well. 
However, for C. coli 3931 (Fig. 3) and C. coli CCUG 10939 , the growth levels after $24 \mathrm{~h}$ were in the range of $10^{4}-10^{5} \mathrm{CFU} / \mathrm{ml}$ in $\mathrm{PB}$ compared to $10^{7}-10^{8}$ $\mathrm{CFU} / \mathrm{ml}$ in both $\mathrm{BB}$ and $\mathrm{MHB}$. For $C$. coli $\mathrm{CCUG}$ 15360 and C. coli CCUG 11283, no growth was detected in PB after $24 \mathrm{~h}$ (data not shown). The growth of the five $C$. coli strains tested was supported equally well by BB and MHB. The five $C$. lari strains tested grew in the range of $10^{4}-10^{5} \mathrm{CFU} / \mathrm{ml}$ in all three enrichment media, showing no difference among the media tested.

\subsection{Spiked samples}

C. jejuni 1677 grew equally well in all three media when spiked at higher levels (10-100 and 100-1000 CFU). However, blood-free BB appeared to be superior than $\mathrm{PB}$ and MHB in supporting the growth of $C$. jejuni 1677 in the low level $(1-10 \mathrm{CFU}$, data not shown). In the non-spiked samples, the level of growth found on blood agar resembled that on mCCDA, indicating that the majority of colonies were thermotolerant campylobacters.

C. coli 3931 grew equally well in the range of $10^{6}-10^{7} \mathrm{CFU} / \mathrm{ml}$ in the three media, regardless of the level of spiking. High levels of non-Campylobacter background flora were registered on blood agar from $\mathrm{PB}$ and MHB, but not from BB (data not shown).

C. jejuni 1677 was detectable by PCR after $24 \mathrm{~h}$ of enrichment regardless of media and sample preparation (Fig. 4). The amplicons obtained from the PB enrichments were weaker than those obtained from $\mathrm{BB}$ and MHB. PCR detection in untreated PB was poor. The best PCR detection was obtained when the DNA was extracted from the samples either by the resin-based method or by boiling. The high spiking levels of $C$. coli 3931 were detectable by PCR as early as after $10 \mathrm{~h}$ of enrichment. After $24 \mathrm{~h}$ of incubation, all levels of spiking were PCR-detectable. Clearer and stronger PCR amplicons were obtained using extracted DNA, especially DNA extracted by the resin-based method. No difference was observed in the PCR results between the three enrichment media.

\subsection{Optimisation of enrichment time}

No thermotolerant campylobacters were detected by culture in the non-spiked samples, i.e. the samples were culture-negative. For C. jejuni 1677, the spiking level had little effect on the level of growth after 24 h of enrichment. For C. coli 3931, the level of growth reflected the spiking level after $24 \mathrm{~h}$ of enrichment (data not shown). In the non-spiked samples added background flora, no bacterial growth was detected on either blood agar or mCCDA. The samples spiked with 100-1000 CFU, to which background flora were added, reached the same level of growth after $24 \mathrm{~h}$ of incubation as the parallel samples without background flora. This was the case for both $C$. jejuni 1677 and $C$. coli 3931. At time zero, the non-spiked samples were negative in the PCR assay. Both C. jejuni 1677 and $C$. coli 3931 were detectable by PCR when the growth

\section{C. jejuni 1677}

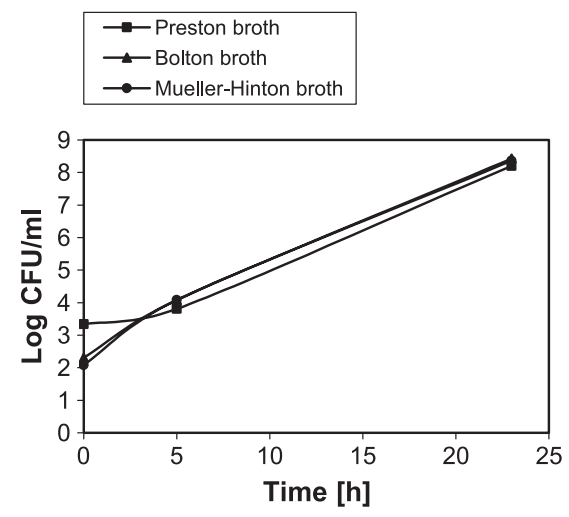

\section{C. coli 3931}
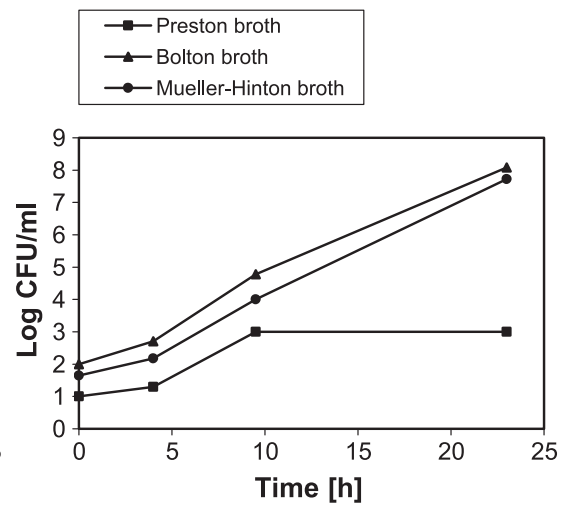

Fig. 3. Typical time-course of growth of $C$. jejuni and $C$. coli in different enrichment broths at $42.0 \pm 1.0{ }^{\circ} \mathrm{C}$ under microaerobic conditions. 


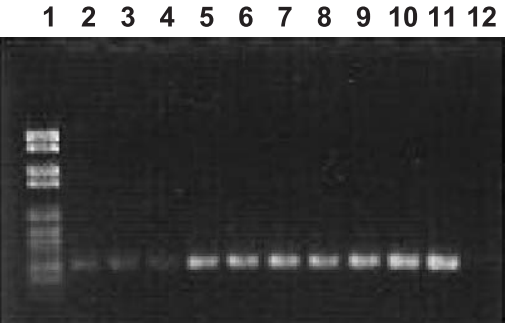

Gel No. 1:

Untreated enrichment broth

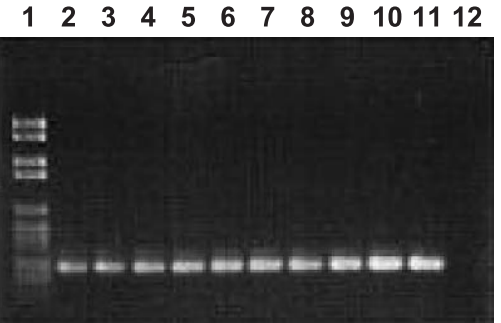

Gel No. 2:

Resin-based DNA extraction $\begin{array}{llllllllllll}1 & 2 & 3 & 4 & 5 & 6 & 7 & 8 & 9 & 10 & 11 & 12\end{array}$

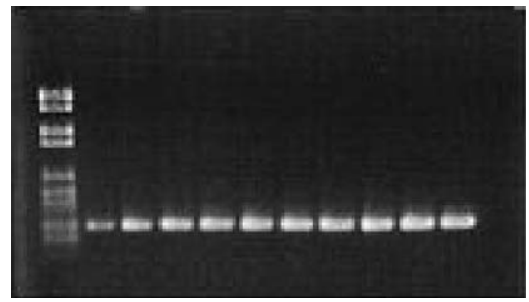

Gel No. 3:

DNA extracted by boiling

Fig. 4. PCR detection of $C$. jejuni 1677 after $24 \mathrm{~h}$ of enrichment. Lane 1: molecular weight marker. Lanes 2-4: Preston broth spiked with 1-10, 10-100 and 100-1000 CFU/20 ml. Lanes 5-7: Mueller-Hinton broth spiked with 1-10, 10-100 and 100-1000 CFU/20 ml. Lanes 8-10: blood-free Bolton broth spiked with 1-10, 10-100 and 100-1000 CFU/20 ml. Lane 11: positive (C. jejuni CCUG 11284) DNA control. Lane 12: blank (water) control.

had reached $10^{4}-10^{5} \mathrm{CFU} / \mathrm{ml}$, corresponding to a detection limit of 50-500 CFU per PCR tube. The time window of detection was $12-24 \mathrm{~h}$ (testing beyond $24 \mathrm{~h}$ was not performed) of enrichment for the samples spiked with $10-100$ and 100-1000 CFU and 16-24 h for the samples spiked with 1-10 CFU.

\subsection{Naturally contaminated samples}

Among the 68 presumably naturally contaminated poultry-rinse samples, 28 were found negative and 40 positive by culture. When tested in the final PCRbased method, 29 samples were negative and 39 positive.

The diagnostic sensitivity of the PCR-based method, defined as the ability to detect thermotolerant Campylobacter when detected by the reference method, was $97.5 \%$. The diagnostic specificity, defined as the ability to not detect thermotolerant Campylobacter when not detected by the reference method, was $100 \%$.

Comparing the culture-based and the PCR-based methods using McNemar's test, the methods performed equally well $(P=0.32)$ in detecting the presence of thermotolerant Campylobacter in chickenrinse and pork swab-rinse.

\section{Discussion}

In general, the strength of PCR is its ability to rapidly screen for negative samples, thereby giving the possibility to focus on supposedly positive samples. The PCR-based method showed a similar diag- nostic accuracy to the standard culture method on naturally contaminated samples. To our knowledge, this is the first international collaborative trial validated, non-commercial PCR-based method, based on the ISO enrichment procedure, making retrospective confirmation of PCR results possible. Furthermore, in compliance with the draft standard on PCR for the detection of foodborne pathogens (ISO/DIS 22174), the method includes a simple sample treatment and an IAC, making it suitable for accreditation in end-user laboratories with quality assurance programs (Anonymous, 2002b).

Preston broth, a common choice of enrichment media in isolating thermotolerant Campylobacter, was poor in supporting the growth of $C$. coli. It has also been shown by $\mathrm{Ng}$ et al. (1985) that some C. coli strains are strongly inhibited by the combination of antibiotics present in PB. Blood-free BB was identified as the most suitable enrichment media, based on its superiority to MHB when low levels of spiking were employed, either with chicken-rinse or pork swab-rinse.

According to the draft standard on PCR testing (ISO/DIS 22174), any enrichment step prior to PCR should follow the standard culture protocol in order to facilitate its implementation in the routine laboratory and provide the possibility of retrospective culture confirmation on the very same samples (Hoorfar and Cook, 2002). As blood-containing BB is currently being accepted as a new enrichment medium in ISO 10272 (Anonymous, 2002a), we evaluated its effect on the growth of thermotolerant Campylobacter. Although blood had no detrimental influence on the 
growth, it did, as expected, cause some inhibition in the PCR detection (data not shown). However, as this could be overcome by extracting the DNA from the enriched broth samples, blood-containing BB was found to be suitable for enrichment-PCR.

Another finding was that extracting the bacterial DNA by the quick and simple resin-based method reduced inhibition by media or sample material. For enrichment-PCR detection of foodborne thermotolerant Campylobacter, several methods have been published (Denis et al., 2001; Giesendorf et al., 1992; Thunberg et al., 2000), although they are labourintensive. The method presented here will be easier to implement in routine analysis.

Because the level of Campylobacter in chickenrinse is often low, PCR-based detection has to be preceded by enrichment. The only available publication on $C$. jejuni PCR testing of non-enriched chicken rinse deals with highly contaminated chicken samples from the Chinese market containing more than $10^{5}$ campylobacters $/ \mathrm{ml}$ (Yang et al., 2003). The Campylobacter contamination level in chicken products in countries with more hygienic production methods is known to be much lower, making enrichment of most samples necessary for PCR detection. Enrichment ensures a higher level of detection by increasing the number of target cells and diluting the food-derived inhibitory substances (Hoorfar and Cook, 2002). Furthermore, as DNA from non-viable cells will be amplified by PCR as well, enrichment will reduce the chance of detection of dead cells by reducing the ratio between dead and living cells (Mandrell and Wachtel, 1999). On the other hand, several Campylobacter enrichment media also contain PCR-inhibitory substances as well, for instance blood (Al-Soud et al., 2000; Al-Soud and Rådström, 2001), bile salts, esculin, acriflavin (Rossen et al., 1992), charcoal and iron (Thunberg et al., 2000). An advantage of introducing the resin-based extraction step in the PCR protocol may be its wider range of application to other food samples and media, which contains different inhibitory substances.

Interestingly, in the present study, the high background flora of chicken or pork samples did not have a negative effect on the growth of Campylobacter in blood-containing BB or the PCR response (Experiment 3). The high incubation temperature combined with the selective pressure of the antibiotics present in the media and the microaerobic environment seemed to restrict the growth of the background flora.

In conclusion, a simple, robust and validated PCRbased method for detection of thermotolerant Campylobacter in chicken-rinse and pork swab-rinse was developed. A user-friendly sample preparation method was shown to overcome inhibition from the samples and the enrichment media, combined with the use of Tth DNA polymerase for PCR amplification. Tth has been proved more resistant to inhibitors than Taq DNA polymerase by Laigret et al. (1996) in amplifying Mycoplasma iowae from culture medium samples by Poddar et al. (1998) in detecting influenza A virus, by Kim et al. (2001) in amplifying Staphylococcus aureus in milk, by Weidbrauk et al. (1995) and by AlSoud and Rådström (1998). Even low numbers of Campylobacter could be detected by PCR after $20 \mathrm{~h}$ of enrichment. The method will be proposed as an international standard, as part of the EU-project FOOD-PCR (QLK1-CT-1999-00226).

The PCR-based method presented compares favourably with the ISO culture method and takes two working days to complete, while the ISO culture methods can take up to 5 days to identify negative samples.

\section{Acknowledgements}

This work was supported in part by EC grant no. QLK1-CT-1999-00226 and grant no. 3401-66-03-5 from the Directorate for Food, Fisheries and Agri Business (DFFE). We thank Mr. Stefan Jensen for excellent technical assistance. We also thank Dr. Nigel Cook for critical reading of the manuscript and Dr. Rene Bødker for advice on the statistical analysis.

\section{References}

Al-Soud, W.A., Rådström, P., 1998. Capacity of nine thermostable DNA polymerises to mediate DNA amplification in the presence of PCR-inhibiting samples. Appl. Environ. Microbiol. 64, $3748-3753$.

Al-Soud, W.A., Rådström, P., 2001. Purification and characterization of PCR-inhibitory components in blood cells. J. Clin. Microbiol. 39, 485-493.

Al-Soud, W.A., Jönsson, L.J., Rådström, P., 2000. Identification 
and characterization of immunoglobin $\mathrm{G}$ in blood as a major inhibitor of diagnostic PCR. J. Clin. Microbiol. 38, 345-350.

Altekruse, S.F., Stern, N.J., Fields, P.I., Swerdlow, D.L., 1999. Campylobacter jejuni-an emerging foodborne pathogen. Emerg. Infect. Dis. 5, 28-35.

Anonymous, 1995. Microbiology of Food and Animal Feeding Stuffs-Horizontal Method for Detection of Thermotolerant Campylobacter, 1 st ed. International Standard Organisation, Geneva, Switzerland. ISO 10272.

Anonymous, 2000. Microbiology of Food and Animal Feeding Stuffs-Preparation of Test Samples, Initial Suspension and Decimal Dilution for Microbiological Examination. Part 2: Specific Rules for the Preparation of the Initial Suspension and Decimal Dilutions of Meat and Meat Products. International Standard Organisation ISO/CD 6887-2 AFNOR, Paris, France.

Anonymous, 2002a. Microbiology of Food and Animal Feeding Stuffs-Horizontal Method for the Detection and Enumeration of Campylobacter Growing at $41.5^{\circ} \mathrm{C}$. Part 1: Detection Method. Doc ISO/TC 34/SC 9 N 553 rev 2. Result of Voting on ISO/ CD 10272-1. International Standard Organisation, Geneva, Switzerland.

Anonymous, 2002b. Microbiology of Food and Animal Feeding Stuffs-Polymerase Chain Reaction (PCR) for the Detection of Foodborne Pathogens-General Method Specific Requirements (ISO/DIS 22174). European Committee for Standardization AFNOR, Paris, France.

Anonymous, 2003. Microbiology of Food and Animal Feeding Stuffs - Carcass Sampling For Microbiological Analysis (ISO/ FDIS 17604). European Committee for Standardization. Afnor, Paris, France.

Denis, M., Refrégier-Petton, J., Laisney, M.J., Ermel, G., Salvat, G., 2001. Campylobacter contamination in French chicken production from farm to consumers. Use of a PCR assay for detection and identification of Campylobacter jejuni and Camp. coli. J. Appl. Microbiol. 91, 255-267.

Englen, M.D., Kelley, L.C., 2000. A rapid DNA isolation procedure for the identification of Campylobacter jejuni by the polymerase chain reaction. Lett. Appl. Microbiol. 31, 421-426.

Friedman, C.R., Neimann, J., Wegener, H.C., Tauxe, R.V., 2000. Epidemiology of Campylobacter jejuni infections in the United States and other industrialised nations. In: Nachamkin, I., Blaser, M.J. (Eds.), Campylobacter. American Society for Microbiology, Washington, DC, pp. 121-138.

Giesendorf, B.A.J., Quint, G.V.W., 1995. Detection and identification of Campylobacter spp. using the polymerase chain reaction. Cell. Mol. Biol. 41, 625-638.

Giesendorf, B.A.J., Quint, G.V.W., Henkens, M.H.C., Stegeman, H., Huf, F.A., Niesters, H.G.M., 1992. Rapid and sensitive detection of Campylobacter spp. in chicken products by using the polymerase chain reaction. Appl. Environ. Microbiol. 58, 3804-3808.

Hoorfar, J., Cook, N., 2002. Critical aspects of standardization of PCRSachse, K., Frey, J. (Eds.), Methods in Molecular Biology: PCR Detection of Microbial Pathogens, vol. 216. Humana Press, Totowa, NJ, pp. 51-64.

Hunt, J.M., Abeyta, C., Tran, T., 1998. Chapter 7 Campylobacter, 8th ed.Bacteriological Analytical Manual Online. U.S. FDA, Washington, D.C. Revision A. Updated 2001. (www.cfsan.fda. gov/ ebam/bam-toc.html).

Josefsen, M.H., Lübeck, P.S., Aalbæk, B., Hoorfar, J., 2002. Preston and Park-Sanders protocols adapted for semi-quantitative isolation of thermotolerant Campylobacter from chicken rinse. Int. J. Food Microbiol. 80, 177-183.

Kim, C.H., Khan, M., Morin, D.E., Hurley, W.L., Tripathy Jr., D.N., Kehrli, M., Oluoch, A.O., Kakoma, I. 2001. Optimization of the PCR for detection of Staphylococcus aureus nuc gene in bovine milk. J. Dairy Sci. 84, 74-83.

Laigret, F., Deaville, J., Bové, J.M., Bradbury, J.M., 1996. Specific detection of Mycoplasma iowae using polymerase chain reaction. Mol. Cell. Probes 10, 23-29.

Lübeck, P.S., Wolffs, P., On, S.L., Ahrens, P., Radstrom, P., Hoorfar, J., 2003a. Toward an international standard for PCR-based detection of food-borne thermotolerant Campylobacters: assay development and analytical validation. Appl. Environ. Microbiol. 69, 5664-5669.

Lübeck, P.S., Cook, N., Wagner, M., Fach, P., Hoorfar, J., 2003 b. Toward an international standard for PCR-based detection of food-borne thermotolerant Campylobacters: validation in a multi-center collaborative trial. Appl. Environ. Microbiol. 69, $5670-5672$.

Magistrado, P.A., Garcia, M.M., Raymundo, A.K., 2001. Isolation and polymerase chain reaction-based detection of Campylobacter jejuni and Campylobacter coli from poultry in the Philippines. Int. J. Food Microbiol. 70, 197-206.

Malorny, B., Hoorfar, J., Hugas, M., Heuvelink, A., Fach, P., Ellerbroek, L., Bunge, C., Dorn, C., Helmut, R., 2003. Inter-laboratory diagnostic accuracy of a Salmonella specific PCR-based method. Int. J. Food Microbiol. 89, 241-249.

Mandrell, R.E., Wachtel, M.R., 1999. Novel detection techniques for human pathogens that contaminate poultry. Curr. Opin. Biotechnol. 10, 273-278.

Moreno, Y., Harnández, M., Ferrús, M.A., Alonso, J.L., Botella, S., Montes, R., Hernández, J., 2001. Direct detection of thermotolerant campylobacters in chicken products by PCR and in situ hybridisation. Res. Microbiol. 152, 577-582.

Ng, L.K., Stiles, M.E., Taylor, D.E., 1985. Inhibition of Campylobacter coli and Campylobacter jejuni by antibiotics used in selective growth media. J. Clin. Microbiol. 22, 510-514.

Ng, L.K., Kingombe, C.I.B., Yan, W., Taylor, D.E., Hiratsuka, K., Malik, N., Garcia, M.M., 1997. Specific detection and confirmation of Campylobacter jejuni by DNA hybridisation and PCR. Appl. Environ. Microbiol. 63, 4558-4563.

O'Sullivan, N.A., Fallon, R., Carroll, C., Smith, T., Maher, M., 2000. Detection and differentiation of Campylobacter jejuni and Campylobacter coli in broiler chicken samples using a PCR/DNA probe membrane based colorimetric detection assay. Mol. Cell. Probes 14, 7-16.

Poddar, S.K., Sawyer, M.H., Connor, J.D., 1998. Effect of inhibitors in clinical specimens on Taq and Tth DNA polymerasebased PCR amplification of influenza A virus. J. Med. Microbiol. 47, 1131-1135.

Rossen, L., Nørskov, P., Holmstrøm, K., Rasmussen, O.F., 1992. Inhibition of PCR by components of food samples, microbial 
diagnostic assays and DNA-extraction solutions. Int. J. Food Microbiol. 17, 37-45.

Siegel, S., Castellan, N.J., 1988. Nonparametric Statistics, 2nd ed. McGraw-Hill, New York.

Thunberg, R.L., Tran, T.T., Walderhaug, M.O., 2000. Detection of thermophilic Campylobacter spp. in blood-free enriched samples of inoculated foods by the polymerase chain reaction. J. Food Prot. 63, 299-303.

Waage, A.S., Vardund, T., Lund, V., Kapperud, G., 1999. Detection of small numbers of Campylobacter jejuni and Campylobacter coli cells in environmental water, sewage, and food samples by a seminested PCR assay. Appl. Environ. Microbiol. 65, 1636-1643.

Walsh, P.S., Metzger, D.A., Higuchi, R., 1991. Chelex 100 as a medium for simple extraction of DNA for PCR-based typing from forensic material. BioTechniques 10, 506-513.
Wang, H., Farber, J.M., Malik, N., Sanders, G., 1999. Improved PCR detection of Campylobacter jejuni from chicken rinses by a simple sample preparation procedure. Int. J. Food Microbiol. 52, $39-45$.

Weidbrauk, D.L., Werner, J.C., Drevon, A.M., 1995. Inhibition of PCR by aqueous and vitreous fluids. J. Clin. Microbiol. 33, $2643-2646$.

Winters, D.K., O'Leary, A.E., Slavik, M.F., 1997. Rapid PCR with nested primers for direct detection of Campylobacter jejuni in chicken washes. Mol. Cell. Probes 11, 267-271.

Yang, C., Jiang, Y., Huang, K., Zhu, C., Yin, Y., 2003. Application of real-time PCR for quantitative detection of Campylobacter jejuni in poultry, milk and environmental water. FEMS Immunol. Med. Microbiol. 38, 265-271. 
Validation of a PCR-based method for detection of food-borne thermotolerant campylobacters in a multicenter collaborative trial. Josefsen, M.H., N. Cook, M. D'Agostino, F. Hansen, M. Wagner, K. Demnerova, A.E. Heuvelink, P.T. Tassios, H. Lindmark, V. Kmet, M. Barbanera, P. Fach, S. Loncarevic, and J. Hoorfar.

Applied and Environmental Microbiology (2004) 70:4379-4383. 


\title{
Validation of a PCR-Based Method for Detection of Food-Borne Thermotolerant Campylobacters in a Multicenter Collaborative Trial
}

\author{
M. H. Josefsen, ${ }^{1}$ N. Cook, ${ }^{2}$ M. D’Agostino, ${ }^{2}$ F. Hansen, ${ }^{3}$ M. Wagner, ${ }^{4}$ K. Demnerova, ${ }^{5}$ \\ A. E. Heuvelink, ${ }^{6}$ P. T. Tassios, ${ }^{7}$ H. Lindmark, ${ }^{8}$ V. Kmet, ${ }^{9}$ M. Barbanera, ${ }^{10}$ \\ P. Fach, ${ }^{11}$ S. Loncarevic, ${ }^{12}$ and J. Hoorfar ${ }^{1 *}$ \\ Danish Institute for Food and Veterinary Research (DFVF), DK-1790 Copenhagen $V^{1}$ and Danish Meat Research Institute, \\ 4000 Roskilde, ${ }^{3}$ Denmark; Defra Central Science Laboratory, Sand Hutton, YO41 1LZ York, United Kingdom ${ }^{2}$; Institute for \\ Milk Hygiene and Milk Technology, 1210 Vienna, Austria ; Institute of Chemical Technology, 16628 Prague 6, Czech \\ Republic ${ }^{5}$; Inspectorate for Health Protection and Veterinary Public Health, 7200 AE Zutphen, The Netherlands ${ }^{6}$; \\ Department of Microbiology, Medical School, Athens University, 11527 Athens, Greece ${ }^{7}$; National Food \\ Agency, 75126 Uppsala, Sweden ${ }^{8}$; Slovak Academy of Science, 4001 Kosice, Slovakia'; Laboratorio \\ Coop Italia, 40033 Casalecchio, Di Reno Bologna, Italy ${ }^{10}$; Agence Française de \\ Sécurité Sanitaire des Aliments, 94700 Maisons Alfort, France ${ }^{11}$; and \\ National Veterinary Institute, 0033 Oslo, Norway ${ }^{12}$
}

Received 24 November 2003/Accepted 5 April 2004

\begin{abstract}
A PCR-based method for rapid detection of food-borne thermotolerant campylobacters was evaluated through a collaborative trial with 12 laboratories testing spiked carcass rinse samples. The method showed an interlaboratory diagnostic sensitivity of $96.7 \%$ and a diagnostic specificity of $100 \%$ for chicken samples, while these values were 94.2 and $83.3 \%$, respectively, for pig samples.
\end{abstract}

Meat products are among the primary sources of food-borne campylobacteriosis (24). Rapid detection of Campylobacter in these foodstuffs can improve food safety (21). To facilitate implementation of the PCR method by the food industry, it is recommended that the performance characteristics of the tests be thoroughly evaluated through collaborative trials (3).

Thus, a European research project, FOOD-PCR, for validation and standardization of noncommercial PCR-based methods as alternatives to traditional culture-based methods was launched (10).

None of the already published PCR-based methods for detection of thermotolerant Campylobacter $(6,7,18,19,22)$ included an internal amplification control (IAC), nor has any been validated through interlaboratory collaborative trials, which are essential if the method is intended as a diagnostic tool in laboratories with quality assurance programs (3).

In the first stages of the project a sensitive and specific PCR assay for the detection of thermotolerant Campylobacter was developed (16) and validated through a multicenter collaborative trial testing purified DNA (17). The assay has been shown to detect all food-borne thermotolerant campylobacters (Campylobacter jejuni, C. coli, and C. lari), which will prepare laboratories for unforeseen shifts in prevalence from one species to the others (16).

To mediate the detection of campylobacters in materials used in primary food production, the PCR assay was incorporated in a complete method, in which the preceding steps were enrichment in Bolton broth followed by a simple and nonpro-

\footnotetext{
* Corresponding author. Mailing address: Danish Institute for Food and Veterinary Research (DFVF), 27 Bülowsvej, DK-1790 Copenhagen V, Denmark. Phone: 45-72 3462 51. Fax: 45-72 3460 01. E-mail: jho@dfvf.dk.
}

prietary DNA extraction procedure (13). The present paper describes the performance of this method in complex matrices (enriched carcass rinse from chickens and pig swabs), as evaluated in a multicenter trial.

The collaborative trial was designed according to international recommendations (2). Twelve laboratories from the United Kingdom, Austria, Germany, Greece, Slovakia, Denmark, the Czech Republic, Italy, Sweden, The Netherlands, and Norway received 24 coded (blind) 1-ml enriched samples, 12 chicken samples and 12 pig samples, spiked with $C$. jejuni 1677 and $C$. coli 3931, respectively. The samples were spiked at the following levels: 0,1 to 10,10 to 100 , and 100 to 1,000 $\mathrm{CFU} / 250 \mathrm{ml}$ (Fig. 1). Applying low, medium, and high levels of spiking makes it possible to assess the usefulness of the test at various infection levels. The shipment also included a positive DNA control, an IAC (16), bovine serum albumin $(20 \mathrm{mg} / \mathrm{ml}$; Sigma, St. Louis, Mo.), and a resin used for the DNA extraction (Chelex-100; Bio-Rad Laboratories, Hercules, Calif.).

A detailed standard operating procedure (SOP) explaining how to perform the pre-PCR treatment and the PCR assay (see www.pcr.dk for detailed information) was sent to the participating laboratories. The SOP required inclusion of a nontemplate control in every setup. The participants purchased their own primers, DNA polymerase (Tth; Applied Biosystems, Foster City, Calif.), and additional reagents from local suppliers. Briefly, the DNA extraction method included short, highspeed centrifugation of $1 \mathrm{ml}$ of enriched broth, addition of Chelex to the pellet, incubation in a $56^{\circ} \mathrm{C}$ water bath, and final centrifugation (13). The SOP also included a reporting sheet, to be returned to the Central Science Laboratory, Sand Hutton, United Kingdom (not the sending laboratory), for statistical analysis. Participants were required to report in detail all 


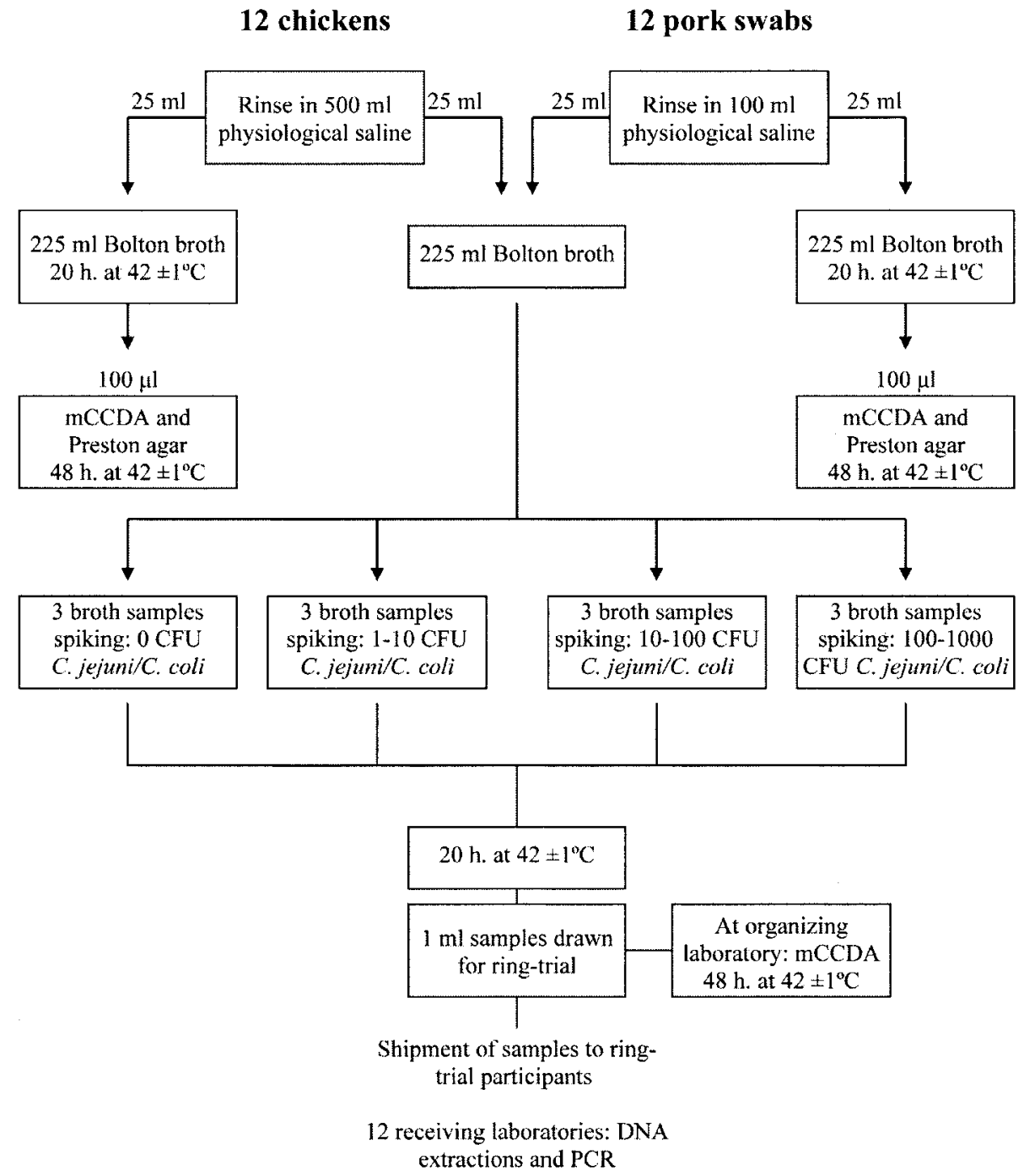

FIG. 1. Flow diagram showing the preparation, spiking, testing, and shipping of samples for the PCR collaborative trial for detection of thermotolerant Campylobacter. The chicken samples were inoculated with $C$. jejuni; the pig samples were inoculated with $C$. coli.

additional information that could possibly have influenced their results.

Twelve frozen chickens, declared to be Campylobacter free by the producer (Danpo A/S, Aars, Denmark), were purchased at local retailers in Copenhagen, Denmark. Initial suspensions of chicken rinse were prepared as recommended in the ISO/ CD 6887-2 protocol (1) and as described by Josefsen et al. (12). The pig carcass swabs, sampled in accordance with ISO/FDIS 17604 (9) by swabbing pig carcass areas of $1,400 \mathrm{~cm}^{2}$ with sterile gauze swabs, were obtained from the Danish Meat Research Institute (Roskilde, Denmark). Initial suspensions of 12 carcass swabs were prepared by washing the swabs in $100 \mathrm{ml}$ of physiological saline for $60 \mathrm{~s}$ (13). As shown in Fig. 1, a total of $25 \mathrm{ml}$ of chicken or pig swab rinse was transferred to $225 \mathrm{ml}$ of blood-containing Bolton broth prepared according to the recommendations of the Bacteriological Analytical Manual Online (11). To verify that the chicken and pig swab rinses were initially culture negative, samples were drawn for intensive culturing before the inoculations. This analysis was conducted in accordance with recommendations of both ISO 10272-1 (4) and the Nordic Committee on Food Analysis (20), in order to verify the Campylobacter-free status of the samples.

C. jejuni 1677 and C. coli 3931 (which are frequently isolated from chickens and pigs, respectively) were inoculated into chicken and pig broth samples, respectively. Three broth samples were left noninoculated, three were inoculated with approximately 1 to $10 \mathrm{CFU} / 250 \mathrm{ml}$, three were inoculated with approximately 10 to $100 \mathrm{CFU} / 250 \mathrm{ml}$, and three were inoculated with approximately 100 to $1,000 \mathrm{CFU} / 250 \mathrm{ml}$. All samples were enriched for $20 \mathrm{~h}$ at $42 \pm 1{ }^{\circ} \mathrm{C}$ under microaerobic conditions. One-milliliter broth samples were drawn and stored at $-80^{\circ} \mathrm{C}$ (maximum storage period: 3 weeks), until shipped on dry ice by courier to the participants. Prior to the shipment, identical samples were tested by PCR in the organizing laboratory (Danish Institute for Food and Veterinary Research, Copenhagen, Denmark) according to the SOP to verify the detection of thermotolerant Campylobacter.

The participating laboratories mailed the results directly to the Central Science Laboratory (a different laboratory than the organizing laboratory). The gel pictures were carefully exam- 
TABLE 1. Reported participant results for the PCR-based method for detection of thermotolerant campylobacters in spiked chicken rinse and pig swab rinse samples

No. of samples positive for the target PCR amplicon

\begin{tabular}{|c|c|c|c|c|c|c|c|c|c|c|c|c|c|c|c|c|c|c|c|c|c|c|c|c|c|}
\hline \multirow{3}{*}{ Inoculation level } & \multirow{3}{*}{ Expected $^{a}$} & \multirow{2}{*}{\multicolumn{12}{|c|}{ From chickens for participant: }} & \multirow{2}{*}{\multicolumn{12}{|c|}{ From pigs for participant: }} \\
\hline & & & & & & & & & & & & & & & & & & & & & & & & & \\
\hline & & 1 & $2^{b}$ & 3 & 4 & 5 & 6 & $7^{c}$ & 8 & 9 & 10 & 11 & 12 & 1 & $2^{b}$ & 3 & 4 & 5 & 6 & $7^{c}$ & 8 & 9 & 10 & 11 & 12 \\
\hline Noninoculated & 0 & 0 & 0 & 0 & 0 & 0 & 0 & 3 & 0 & 0 & 0 & 0 & 0 & 0 & 0 & 0 & 1 & 0 & 0 & 3 & 1 & 0 & 1 & 2 & 0 \\
\hline Low (1-10 CFU) & 3 & 3 & 0 & 3 & 3 & 3 & 3 & 3 & 3 & 1 & 3 & 3 & 3 & 3 & 0 & 3 & 3 & 3 & 3 & 3 & 3 & 3 & 3 & 3 & 3 \\
\hline Medium (10-100 CFU) & 3 & 3 & 0 & 3 & 3 & 3 & 3 & 3 & 3 & 2 & 3 & 3 & 3 & 3 & 0 & 3 & 3 & 3 & 3 & 3 & 3 & 3 & 3 & 2 & 3 \\
\hline High (100-1,000 CFU) & 3 & 3 & 0 & 3 & 3 & 3 & 3 & 3 & 3 & 3 & 3 & 3 & 3 & 3 & 0 & 3 & 3 & 3 & 3 & 3 & 3 & 3 & 3 & 2 & 3 \\
\hline
\end{tabular}

${ }^{a}$ From analysis of triplicate samples.

${ }^{b}$ Excluded due to omission of the IAC in the PCR mixture.

${ }^{c}$ Excluded due to the presence of target amplicons in the assay negative control.

ined, and the results were approved for inclusion in statistical analysis unless they fell into one of the following two categories: (i) obvious performance deviation from the SOP and (ii) presence of target amplicons in negative PCR controls, indicating contamination.

Table 1 shows the participants' results for the collaborative trial. In agreement with the predefined criteria, the results of partner 2 were excluded, as this partner did not include the IAC in the PCR mixture and thus was not able to determine whether the samples were truly negative or whether the absence of target amplicons was due to PCR inhibition. The results of partner 7 were also excluded, as partner 7 reported target amplicons in the assay negative control, indicating possible cross-contamination. All remaining results were accepted according to the predefined criteria; thus the final statistical analysis was based on 10 sets of results (Table 2).

The PCR results were analyzed statistically according to the recommendations of Scotter et al. (23) by the method of Langton et al. (14). The interlaboratory diagnostic sensitivity was defined as the percentage of positive samples giving a correct positive signal (8). The interlaboratory diagnostic specificity was defined as the percentage of negative samples giving a correct negative signal, as well as a signal from the IAC (8). Confidence intervals (CI) for interlaboratory diagnostic sensitivity and specificity were calculated by the method of Wilson (25). Accordance (repeatability of qualitative data) and concordance (reproducibility of qualitative data) were defined as the percentages of finding the same result, positive or negative, from two similar samples analyzed in, respectively, the same or different laboratories under standard repeatability conditions. These calculations take into account different replications in different laboratories by weighting results appropriately. The concordance odds ratio (COR) was defined as the degree of between-laboratory variation in the results. The COR was expressed as the ratio between accordance and concordance percentages. CI for accordance, concordance, and COR were calculated by the method of Davidson and Hinckley (5).

For chicken samples, the interlaboratory diagnostic sensitivity of the PCR was greater than $90 \%$ for each of the inoculation levels, and calculating the interlaboratory diagnostic sensitivity for all inoculation levels gave a value of $96.7 \%$ (Table 2). Accordance (repeatability) and concordance (reproducibility) values were thus high in each case. With samples inoculated with 1 to $10 \mathrm{CFU}$, a degree of interlaboratory variation was noted; this was due to one laboratory reporting two falsenegative results. The COR value can be interpreted as the likelihood of obtaining the same result from two identical samples, whether they are sent to the same laboratory or to two different laboratories. The closer the value is to 1.0, the higher the likelihood is of obtaining the same result. In all cases, the COR value fell within the $95 \% \mathrm{CI}$, indicating that the interlaboratory diagnostic sensitivity of the method was as repeatable as it was reproducible (Table 2). Thus, the method is effective at detecting thermotolerant Campylobacter in the sample types tested. Conversely, and more importantly, there is a very low risk of obtaining false-negative responses: the interlaboratory diagnostic specificity, or percentage of correctly identified noninoculated chicken samples, was $100 \%$, with complete accordance and concordance. The PCR-based method reported performed favorably compared to the International Standard Organisation culture method (13). The latter takes 5 days to identify negative samples, while the method reported here takes only two working days. Here it must be emphasized that the main advantage of PCR over culture methods is its potential for rapid screening of negative samples, which allows for greater resources to be directed toward characterization and epidemiological tracking of positive isolates. In end use laboratories using PCR for screening purposes, a confirmation of PCR-positive responses by culture may not be necessary.

A similar approach has been used in Denmark for identification of infected flocks prior to and after slaughter, in order to provide the consumers with campylobacter-free chickens, declared as such. The implementation of the so-called "strategic slaughter," where infected flocks are slaughtered at the end of the day, seems to have contributed to the recent significant decline of human campylobacteriosis in Denmark (www.dzc.dk).

For the pig samples, the interlaboratory diagnostic sensitivity of the PCR was greater than $90 \%$ for each inoculation level and calculating the interlaboratory diagnostic sensitivity for all inoculation levels resulted in a value of $94.2 \%$ (Table 2). In all cases accordance and concordance values were high, and the CORs showed that the interlaboratory diagnostic sensitivity was equally repeatable and reproducible. For these samples, the interlaboratory diagnostic specificity was $83.3 \%$, reflecting a greater degree of interlaboratory variation in results for pig samples. This was due to four laboratories reporting positive amplicons from noninoculated samples. Since the pig samples had previously been identified as Campylobacter free, both by culture and PCR in the sending laboratory, cross-contamination in the receiving laboratories could explain these results. With hindsight, this could have been controlled within the trial 
by including a processing negative control (PNC), e.g., a sample comprising sterile water, which underwent treatment identical to that of the samples. A positive result from a PNC sample would reveal the occurrence of cross-contamination. This is a drawback of the present study, which should be avoided in similar trials in the future. In addition, if the method is to be performed routinely, it is strongly recommended that such controls be included throughout the entire test process, including sample preparation, enrichment, DNA extraction, and target amplification (3). However, in routine application of the PCR method, any positive response should be confirmed by reanalyzing the retained Bolton broth culture by the ISO method.

To our best knowledge, no other collaborative trial has validated a similar noncommercial, open-formula PCR for Campylobacter (15). The method does not require procurement of costly equipment. These features, in combination with the validation presented here, make it suitable for routine use and thus appropriate for accreditation.

The work was supported in part by EC grants QLK1-CT-1999-00226 and 3401-66-03-5 from the Directorate for Food, Fisheries and Agricultural Business.

The following contributed with their participation in the collaborative trial: M. Wagner, K. Demnerova, A. E. Heuvelink, V. Kmet, P. Fach, H. Lindmark, P. T. Tassios, S. Loncarevic, M. Barbanera, M. Kuhn, and A. Abdulmawjood. We acknowledge the technical assistance of all the laboratory staff involved in preparing and analyzing the samples used in the collaborative trial. Danpo provided the chicken samples.

\section{REFERENCES}

1. Anonymous. 2000. Microbiology of food and animal feeding stuffs. Preparation of test samples, initial suspension and decimal dilution for microbiological examination. Part 2. Specific rules for the preparation of the initial suspension and decimal dilutions of meat and meat products. International Standard Organisation ISO/CD 6887-2. ISO, Geneva, Switzerland.

2. Anonymous. 2001. NordVal validation. Protocol for the validation of alternative microbiological qualitative methods. NV-DOC. D-2001-04-25. FDIR, Copenhagen, Denmark.

3. Anonymous. 2002. Microbiology of food and animal feeding stuffs. Polymerase chain reaction (PCR) for the detection of foodborne pathogens. General method specific requirements. Draft international standard ISO/DIS 22174. DIN, Berlin, Germany.

4. Anonymous. 2002. Microbiology of food and animal feeding stuffs. Horizontal method for the detection and enumeration of Campylobacter growing at $41.5^{\circ} \mathrm{C}$. Part 1. Detection method. International Standard Organisation ISO/TC 34/SC 9 N 553, revision 2. Result of voting on ISO/CD 10272-1. AFNOR, Paris, France.

5. Davidson, A. C., and D. V. Hinckley. 1997. Bootstrap methods and their application. Cambridge University Press, Cambridge, United Kingdom.

6. Denis, M., J. Refrégier-Petton, M. J. Laisney, G. Ermel, and G. Salvat. 2001. Campylobacter contamination in French chicken production from farm to consumers. Use of a PCR assay for detection and identification of Campylobacter jejuni and Camp. coli. J. Appl. Microbiol. 91:255-267.

7. Englen, M. D., and L. C. Kelley. 2000. A rapid DNA isolation procedure for the identification of Campylobacter jejuni by the polymerase chain reaction. Lett. Appl. Microbiol. 31:421-426.

8. European Committee for Standardization. 2002. Microbiology of food and animal feeding stuffs. Protocol for the validation of alternative methods (ISO/FIDS 16140). AFNOR, Paris, France.

9. European Committee for Standardization. 2003. Microbiology of food and animal feeding stuffs. Carcass sampling for microbiological analysis (ISO/ FIDS 17604). AFNOR, Paris, France.

10. Hoorfar, J. 1999. EU seeking to validate and standardize PCR testing of food pathogens. ASM News 65:799.

11. Hunt, J. M., C. Abeyta, and T. Tran. 1998. Campylobacter. In G. J. Jackson, R. I. Merker, and R. Bandler (ed.), Bacteriological analytical manual online, 8th ed., revision A. [Online.] www.cfsan.fda.gov/ ebam/bam-toc.html.

12. Josefsen, M. H., P. S. Lübeck, B. Aalbäk, and J. Hoorfar. 2002. Preston and Park-Sanders protocols adapted for semi-quantitative isolation of thermotolerant Campylobacter from chicken rinse. Int. J. Food Microbiol. 80:177183.

13. Josefsen, M. H., P. S. Lübeck, F. Hansen, and J. Hoorfar. 2004. Towards an 
international standard for PCR-based detection of foodborne thermotolerant campylobacters: interaction of enrichment media and pre-PCR treatment on carcass rinse samples. J. Microbiol. Methods 58:39-48.

14. Langton, S. D., R. Chevennement, N. Nagelkerke, and B. Lombard. 2002. Analysing collaborative trials for qualitative microbiological methods: accordance and concordance. Int. J. Food Microbiol. 79:175-181.

15. Lübeck, P. S., and J. Hoorfar. 2002. PCR technology and applications to zoonotic foodborne bacterial pathogens. Methods Mol. Biol. 216:65-84

16. Lübeck, P. S., P. Wolffs, S. L. On, P. Ahrens, P. Radstrom, and J. Hoorfar 2003. Toward an international standard for PCR-based detection of foodborne thermotolerant campylobacters: assay development and analytical validation. Appl. Environ. Microbiol. 69:5664-5669.

17. Lübeck, P. S., N. Cook, M. Wagner, P. Fach, and J. Hoorfar. 2003. Toward an international standard for PCR-based detection of food-borne thermotolerant campylobacters: validation in a multicenter collaborative trial. Appl Environ. Microbiol. 69:5670-5672.

18. Magistrado, P. A., M. M. Garcia, and A. K. Raymundo. 2001. Isolation and polymerase chain reaction-based detection of Campylobacter jejuni and Campylobacter coli from poultry in the Philippines. Int. J. Food Microbiol 70:197-206.

19. Moreno, Y., M. Harnández, M. A. Ferrús, J. L. Alonso, S. Botella, R. Montes, and J. Hernández. 2001. Direct detection of thermotolerant campylobacters in chicken products by PCR and in situ hybridisation. Res. Microbiol. 152: 577-582.

20. Nordic Committee on Food Analysis. 2002. Campylobacter. Detection and enumeration of thermotolerant Campylobacter in foods. Draft version. Nordic Committee on Food Analysis, Oslo, Norway.

21. On. S. L. W. 1996. Identification methods for campylobacters, helicobacters, and related organisms. Clin. Microbiol. Rev. 9:405-422.

22. O'Sullivan, N. A., R. Fallon, C. Carroll, T. Smith, and M. Maher. 2000 Detection and differentiation of Campylobacter jejuni and Campylobacter coli in broiler chicken samples using a PCR/DNA probe membrane based colorimetric detection assay. Mol. Cell Probes 14:7-16.

23. Scotter, S. L., S. Langton, B. Lombard, N. Schulten, N. Nagelkerke, P. H. In't Veld, P. Rollier, and C. Lahellec. 2001. Validation of ISO method 11290. Part 1. Detection of Listeria monocytogenes in foods. Int. J. Food Microbiol. 64:295-306.

24. Tauxe, R. V. 2002. Emerging foodborne pathogens. Int. J. Food Microbiol. 78:31-41.

25. Wilson, E. B. 1927. Probable inference, the law of succession, and statistical inference. J. Am. Statis. Assoc. 22:209-212. 
Enrichment followed by quantitative PCR both for rapid detection and as a tool for quantitative risk assessment of food-borne thermotolerant campylobacters. Josefsen, M.H., N.R. Jacobsen, and J. Hoorfar.

Applied and Environmental Microbiology (2004) 70:3588-3592. 


\title{
Enrichment Followed by Quantitative PCR both for Rapid Detection and as a Tool for Quantitative Risk Assessment of Food-Borne Thermotolerant Campylobacters
}

\author{
M. H. Josefsen, N. R. Jacobsen, and J. Hoorfar* \\ Danish Institute for Food and Veterinary Research, DK-1790 Copenhagen V, Denmark
}

Received 10 December 2003/Accepted 2 March 2004

\begin{abstract}
As part of a large international project for standardization of PCR (Food-PCR; www.pcr.dk), a multiplex, multiplatform, ready-to-go enrichment followed by a real-time PCR method, including an internal amplification control, was developed for detection of food-borne thermotolerant campylobacters in chickens. Chicken rinse samples were enriched in Bolton broth for $20 \mathrm{~h}$, a simple and rapid (1-h) resin-based DNA extraction was performed, and DNA samples were then tested with two instrument platforms: ABI-PRISM 7700 and RotorGene 3000. The method was validated against an International Standard Organization (ISO)-based culture method by testing low, medium, and high levels of 12 spiked and 66 unspiked, presumably naturally contaminated, chicken rinse samples. In the RotorGene, a positive PCR response was detected in $\mathbf{4 0}$ samples of the 66. This was in complete agreement with the enriched ISO culture. The ABI-PRISM 7700 missed one culture-positive sample. Positive samples contained $10^{2}$ to $10^{7} \mathrm{CFU} / \mathrm{ml}$ after enrichment in Bolton broth. In the enriched samples a detection probability of $95 \%$ was obtained at levels of $1 \times 10^{3}$ and $2 \times 10^{3} \mathrm{CFU} / \mathrm{ml}$ in the RotorGene and ABI-PRISM, respectively. The amplification efficiency in both platforms was $90 \%$, although the linear range of amplification of purified genomic DNA was $1.5 \times 10^{1}$ to $1 \times 10^{7}\left(R^{2}=1.00\right)$ for the RotorGene and $10^{3}$ to $10^{7}\left(R^{2}=0.99\right)$ for the ABI-PRISM. In RotorGene and ABI-PRISM the levels of precision of detection as determined by standard deviation (coefficients of variation) of 6-carboxyfluorescein (FAM) threshold cycle $(\mathrm{Ct})$ values were 0.184 to $0.417(0.65$ to $2.57 \%)$ and 0.119 to $0.421(0.59$ to $1.82 \%)$, respectively. The results showed a correlation $\left(R^{2}\right)$ of 0.94 between the target FAM Ct values and CFU per milliliter of enriched naturally contaminated chicken samples, which indicates PCR's additional potential as a tool for quantitative risk assessment. Signal from the internal amplification control was detected in all culture-negative samples (VIC Ct: 23.1 to 28.1). The method will be taken further and validated in an international collaborative trial with regard to standardization.
\end{abstract}

Thermotolerant campylobacters especially Campylobacter jejuni and C. coli are recognized worldwide as a leading cause of human food-borne infections (19). They are zoonotic bacteria, with many wild and domesticated animals serving as potential reservoirs. Sources of sporadic campylobacteriosis are seldom identified, but water, pets, and especially poultry products are known to be associated with the illness (14). There is a need for rapid detection methods during chicken production, in order to prevent distribution of infected chicken products to consumers. Rapid methods, as currently practiced in Denmark, can be used on-site to quickly identify infected flocks prior to and after slaughter and to provide the consumers with Campylobacter-free chickens. The implementation of the so-called "strategic slaughter" seems to have contributed to the recent decline of campylobacteriosis in Denmark (www.dfvf.dk). In addition, quantitative detection tools are needed for estimation of the level of Campylobacter in flocks and meat products, as part of risk assessment studies.

A limited number of real-time PCR methods have been reported for the specific detection of $C$. jejuni $(5,15,18,20)$. The present study deals with detection of all food-borne ther-

* Corresponding author. Mailing address: Danish Institute for Food and Veterinary Research, 27 Bülowsvej, DK-1790 Copenhagen V, Denmark. Phone: (45) 72346251. Fax: (45) 72346360. E-mail: jho @ dfvf.dk. motolerant campylobacters (C. jejuni, C. coli, and C. lari), which would prepare laboratories for an unforeseen shift of prevalence in poultry from $C$. jejuni to currently less frequently isolated species. In addition we have included an internal amplification control (IAC), which is mandatory according to the draft international standard (4). Furthermore, the real-time PCR method reported here is based on a specific and robust conventional gel-based PCR method validated in an international collaborative trial $(10,11)$. Closed-tube real-time PCR assays can be more specific than gel-based PCR due to the inclusion of a target sequence-recognizing probe. They can also be faster and more sensitive and involve less manual handling than conventional PCR. Finally, the risk of carryover contamination is substantially reduced, which makes them more suitable for implementation in end use laboratories.

To our knowledge, this is the first study to report an enrichment multiplatform real-time PCR, including an IAC, which deals with the detection of all three food-borne thermotolerant campylobacters and to provide data to support its potential use as a quantitative tool in risk assessment studies.

\section{MATERIALS AND METHODS}

Spiked and naturally contaminated samples. (i) Spiked samples. The PCR method was validated on 12 frozen slaughtered chickens (Danpo A/S, Aars, Denmark), purchased at local retailers as Campylobacter free. Initial suspensions of chicken carcass rinse were prepared as recommended in the ISO/CD 6887-2 protocol (1). A whole thawed chicken was placed in a large sterile plastic bag, 500 
$\mathrm{ml}$ of physiological saline $(0.9 \% \mathrm{NaCl})$ was added, and the bag was closed and shaken gently by hand for a minimum of $60 \mathrm{~s}(8)$. Then $25 \mathrm{ml}$ of chicken carcass rinse was transferred to $225 \mathrm{ml}$ of Bolton broth (BB) prepared according to the recommendations of the Bacteriological Analytical Manual Online (6). The broth samples were inoculated with $C$. jejuni strain 1677 , which represents a genotype frequently isolated from chickens in Denmark. Three broth samples were not inoculated; three were inoculated with approximately 1 to $10 \mathrm{CFU} / 250 \mathrm{ml}$, three were inoculated with approximately 10 to $100 \mathrm{CFU} / 250 \mathrm{ml}$, and three were inoculated with approximately 100 to $1,000 \mathrm{CFU} / 250 \mathrm{ml}$. They were incubated at $42.0 \pm 1.0^{\circ} \mathrm{C}$ under microaerobic conditions $\left(6 \% \mathrm{O}_{2}, 7 \% \mathrm{CO}_{2}, 7 \% \mathrm{H}_{2}\right.$, and $80 \%$ $\mathrm{N}_{2}$ ) for $20 \mathrm{~h}$. Following the enrichment, the concentrations of $C$. jejuni 1677 in the spiked samples were approximately $0,10^{4}, 10^{5}$, and $10^{6} \mathrm{CFU} / \mathrm{ml}$. After $20 \mathrm{~h}$ of enrichment, 1-ml samples were drawn for PCR and stored at $-80^{\circ} \mathrm{C}$. To verify that the chicken carcass rinse was initially Campylobacter free, prespiking samples were drawn for traditional microbiological analysis before inoculation. The microbiological analysis was conducted in accordance with recommendations of the International Standard Organization (3) and the Nordic Committee on Food Analysis (2). The CFU levels postenrichment were determined by plating $100 \mu \mathrm{l}$ of a 10 -fold dilution series $\left(10^{-1}, 10^{-2}, 10^{-3}, 10^{-4}, 10^{-5}, 10^{-6}\right.$, and $\left.10^{-7}\right)$ onto modified charcoal cefoperazone deoxycholate agar (Oxoid, Basingstoke, United Kingdom) and Preston agar (Oxoid). The agar plates were incubated for $48 \mathrm{~h}$ at $42.0 \pm 1.0^{\circ} \mathrm{C}$ under microaerobic conditions. Five typical colonies from each plate were verified by applying the following tests: Gram reaction by the $\mathrm{KOH}$ $3 \%$ method, oxidase test, catalase test, and microscopic inspection of motility and morphology (8).

(ii) Naturally contaminated samples. Sixty-six chickens, including 26 Danish and 40 French free-range or intensively reared chickens, were purchased on six different occasions at local retailers. The chicken carcass rinses were prepared as described above. Twenty-five milliliters of the chicken carcass rinse was transferred to $225 \mathrm{ml}$ of $\mathrm{BB}$ and enriched for $20 \mathrm{~h}$, after which 1-ml samples were drawn for PCR and stored at $-80^{\circ} \mathrm{C}$. Microbiological analysis was conducted as described in the section for spiked samples.

Preparation of template DNA. A simple and rapid resin-based sample treatment was performed essentially as described by Malorny et al. (13). Briefly, the 1-ml frozen enriched BB samples were thawed and centrifuged for $5 \mathrm{~min}$ at $10,000 \times g$ and $4^{\circ} \mathrm{C}$. The pellets were resuspended in $300 \mu \mathrm{l}$ of $6 \%$ Chelex 100 resin suspension (Bio-Rad Laboratories, Hercules, Calif.) and incubated for 20 $\min$ in a $56^{\circ} \mathrm{C}$ water bath. The samples were vortexed for $10 \mathrm{~s}$ and incubated in a $95^{\circ} \mathrm{C}$ water bath for $8 \mathrm{~min}$, followed by immediate chilling on ice. The samples were centrifuged for $5 \mathrm{~min}$ at $14,000 \times g$ and $4^{\circ} \mathrm{C}$, and $5 \mu \mathrm{l}$ of the supernatants was used as the template in the PCR. The spiked and naturally contaminated samples were run in duplicate in an ABI-PRISM 7700 sequence detector (Applied Biosystems, Foster City, Calif.) and a RotorGene 3000 (Corbett Research, Mortlake, Australia). Preparation of the IAC template (hemorrhagic septicemia virus mRNA for envelope protein; GenBank accession no. X66134) was performed as previously described (10).

Campylobacter real-time PCR. The real-time PCR was performed in the ABIPRISM using 0.2-ml thermostrips (ABgene House, Surrey, United Kingdom) or MicroAmp Optical 96-well reaction plates (Applied Biosystems) closed with MicroAmp Optical caps (Applied Biosystems) and in the RotorGene using 0.2-ml capped tubes (Corbett Research). The $25-\mu \mathrm{l}$ real-time PCR mixture contained $1 \times$ PCR buffer for Tth DNA polymerase (Roche A/S, Hvidovre, Denmark), $1 \mathrm{U}$ of Tth DNA polymerase (Roche A/S), $0.4 \mathrm{mM}$ deoxynucleoside triphosphate mixture (Amersham Pharmacia Biotech, Buckinghamshire, United Kingdom), $0.44 \mu \mathrm{M}$ forward primer 5' CTG CTT AAC ACA AGT TGA GTA GG 3', $0.48 \mu \mathrm{M}$ reverse primer 5' TTC CTT AGG TAC CGT CAG AA 3' (DNA Technology, Århus, Denmark; C. jejuni 16S rRNA; GenBank accession no. Y19244), $2.5 \mathrm{mM} \mathrm{MgCl}_{2}$ (Applied Biosystems), $30 \mu \mathrm{g}$ of bovine serum albumin (BSA) for chicken samples and $5 \mu \mathrm{g}$ of BSA for pure DNA (Roche $\mathrm{A} / \mathrm{S}), 20 \mathrm{nM}$ target Campylobacter probe labeled with 6-carboxyfluorescein (FAM; reporter dye) and 6-carboxytetramethylrhodamine (TAMRA; quencher dye) (5' FAM-TGT CAT CCT CCA CGC GGC GTT GCT GC-TAMRA 3'; DNA Technology), $50 \mathrm{nM}$ IAC probe (5' VIC-TTC ATG AGG ACA CCT GAG TTG A-TAMRA 3'; Applied Biosystems), $5 \times 10^{3}$ copies of IAC (124 bp), and $5 \mu \mathrm{l}$ of DNA sample. The cycle profile was as follows: initial denaturation at $95^{\circ} \mathrm{C}$ for $3 \mathrm{~min}$, followed by 40 cycles of $95^{\circ} \mathrm{C}$ for $15 \mathrm{~s}$ and $58^{\circ} \mathrm{C}$ for $60 \mathrm{~s}$. Fluorescence measurements were obtained online and analyzed on the ABI-PRISM with the SDS software (version 1.7a; Applied Biosystems) and on the RotorGene with the version 4.6 software (Corbett Research). Note that no passive reference fluorescence was assigned on the ABI-PRISM, since the PCR mixture did not contain any 6-carboxy-X-rhodamine. The real-time PCR method is based on a specific and robust conventional gel-based PCR method validated in an international collaborative trial. No attempt was made to analyze the specificity of the test since the primers used previously have been validated against 150 related and nonrelated species $(10,11)$.

Determination of cutoff. The FAM threshold was assigned to a fixed value intersecting the amplification curves in the linear region of the logarithmic plot (a normalized reporter signal, $\Delta \mathrm{Rn}$, of 230 for the ABI-PRISM and a normalized fluorescence of 0.02 for the RotorGene). The fluorescence was normalized to the background signal, as no 6-carboxy-X-rhodamine was present in the master mixture. Any sample showing a fluorescence signal above this value was regarded as positive. The VIC threshold was assigned a normalized reporter signal $(\Delta \mathrm{Rn})$ of 100 for the ABI-PRISM and a normalized fluorescence of 0.01 for the Rotor Gene. To exclude possible weak signals from samples or nontemplate controls with a slight end point drift upward, a $10 \%$ quantitation setting on the RotorGene was employed, meaning that the software would reject any reaction not increasing more than $10 \%$ in fluorescence relative to the samples producing the highest fluorescence increase in the real-time run.

Detection probability. The probability of detection was examined essentially as described by Knutsson et al. (9). Six chicken carcass rinse samples containing approximately $10^{1}$ to $10^{6}$ Campylobacter $\mathrm{CFU} / \mathrm{ml}$ were tested. Five microliters of extracted DNA from each sample was added to five separate real-time PCR tubes and was run as described above on both the ABI-PRISM and the RotorGene. This experiment was repeated five times in the same PCR run on six separate occasions, resulting in a total of 30 responses for each chicken sample. Master mixture was prepared on each of the six occasions and divided among five PCR tubes. DNA was added to the tubes individually. The real-time PCR response was regarded as binary, giving either a positive or a negative signal, according to the cutoff criteria described earlier. The detection probability in spiked chicken carcass rinse samples was obtained by plotting the relative percentage of positive PCR responses against the cell concentration in the samples tested. A sigmoid line fitting was performed with ORIGIN, version 4.0 (Microcal Software, Northampton, Mass.).

Precision of detection. Chicken carcass rinse samples spiked with 0,1 to 10,10 to 100 , and 100 to $1,000 \mathrm{CFU} / 250 \mathrm{ml}$, in the presence of $5 \times 10^{3}$ copies of the IAC, were used to establish the precision of detection. Five microliters of DNA extracted from three spiked samples from each level was added to 10 separate real-time PCR tubes, and samples were run as described above on both the ABI-PRISM and the RotorGene. For statistical analysis the results for the precision of detection were plotted into the Online Calculator for Standard Deviation (www.compute.uwlax.edu/stats/), and the standard deviation (SD), sample variance $\left(s^{2}\right)$, and the coefficient of variation $(\mathrm{CV})$ were computed.

Amplification efficiency and linear range. The amplification efficiency and linear range of the real-time PCR method were determined in quadruple by using purified DNA from plate colonies in the concentration range of $5 \times 10^{0}$ to $1 \times 10^{7}$ copies of genomic DNA from type strain C. jejuni CCUG 11284. The analysis was performed on both the ABI-PRISM and the RotorGene. By plotting the number of genomic DNA copies/25 $\mu$ l of PCR sample against the threshold cycle value $(\mathrm{Ct}$; the fractional PCR cycle at which the fluorescence signal of a sample rises above the determined baseline signal), a linear relationship was formed. The slope of this curve was used to determine the amplification efficiency from the equation amplification efficiency $=10^{-1 / \text { slope }}-1$. The DNA was extracted with a DNeasy tissue kit (QIAGEN GmbH, Hilden, Germany) according to the manufacturer's instructions. The DNA concentration was determined by PicoGreen quantitation of double-stranded DNA with a TD-360 minifluorometer (Turner Designs, Sunnyvale, Calif.) (7). The number of genomic copies of the purified DNA was calculated from the equation $m=n\left(1.013 \times 10^{-21}\right)$, where $m$ is the mass, and $n$ is the number of base pairs in the genome (12). The genomic sequence of $C$. jejuni NCTC11168 has been determined by Parkhill et al. (16) to be 1,641,481 bp. Entering this in the above equation yields the result that one $C$. jejuni genome weighs approximately $1.7 \mathrm{fg}$. The number of genomic DNA copies/milliliter was adjusted with $1 \times$ Tris-EDTA buffer-0.1 M EDTA.

\section{RESULTS}

Amplification efficiency and linear range. The standard curves produced directly by software for both platforms are shown in Fig. 1. The linear range of amplification for the PCR method was between $5 \times 10^{1}$ and $1 \times 10^{7}$ copies of purified genomic DNA from $C$. jejuni CCUG 11284 in the RotorGene and $10^{3}$ to $10^{7}$ copies in the ABI-PRISM (Fig. 2). The amplification efficiency was computed from the slope of the linear relationship $\left(R^{2}=1.00\right)$ and was $90.6 \%$ for the RotorGene. In 


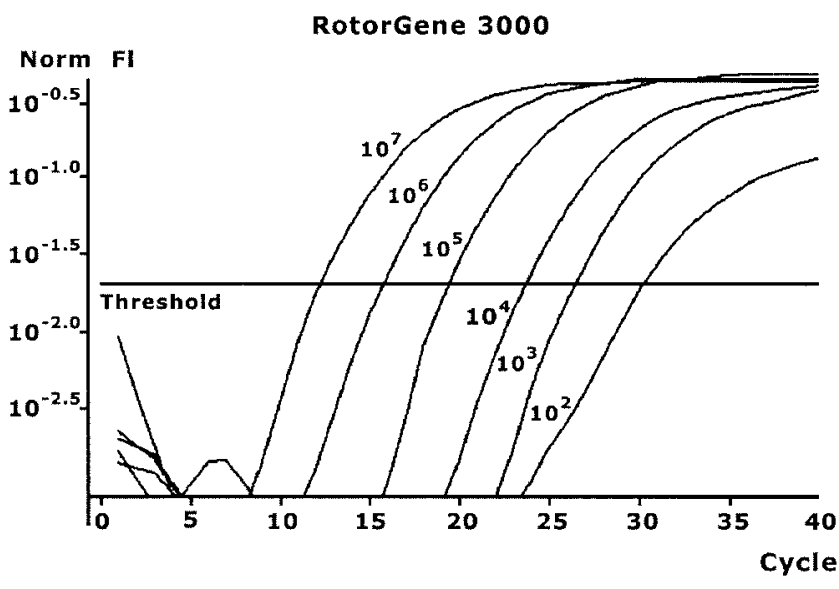

ABI PRISM 7700

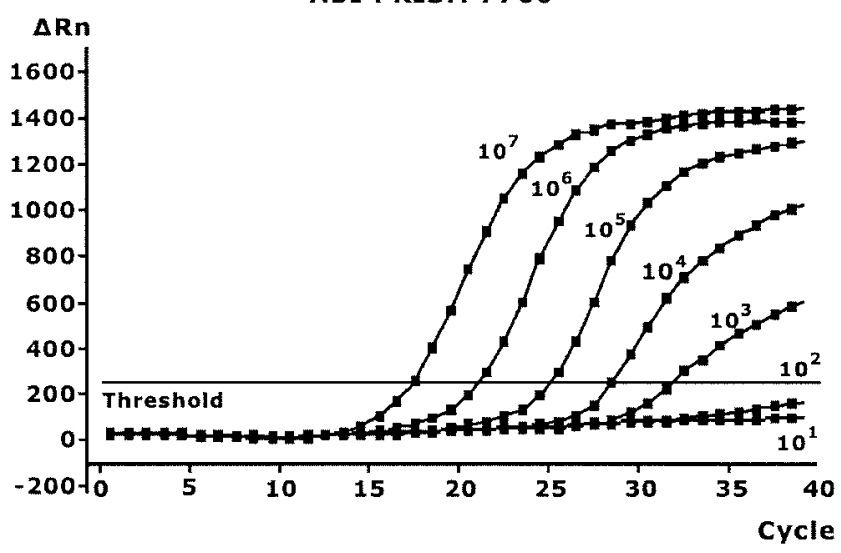

FIG. 1. Standard curves produced from purified DNA in the range of $10^{1}$ to $10^{7}$ copies of genomic DNA from type strain $C$. jejuni CCUG 11284 on the ABI-PRISM 7700 and the RotorGene 3000. The lowest level, $10^{1}$ copies, is not shown for the RotorGene since it was eliminated by the quantification settings of $10 \%$. Norm $\mathrm{fl}$, normalized fluorescence.

the ABI-PRISM the results were $89.9 \%$ for amplification efficiency and a linear relationship of $R^{2}=0.99$.

Detection probability. Figure 3 shows the probability of detecting C. jejuni 1677 in chicken carcass rinse samples by the real-time PCR method. On the ABI-PRISM the detection probability for $10^{3} \mathrm{CFU} / \mathrm{ml}$ was $85 \%$ and for $4 \times 10^{3} \mathrm{CFU} / \mathrm{ml}$ it was $100 \%$. On the RotorGene the probability of detecting $10^{3} \mathrm{CFU} / \mathrm{ml}$ was $90 \%$, while it was $100 \%$ for detecting $4 \times 10^{3}$ $\mathrm{CFU} / \mathrm{ml}$. The levels of detection at $95 \%$ probability were determined to be $2 \times 10^{3} \mathrm{CFU} / \mathrm{ml}$ for the ABI-PRISM and $10^{3}$ $\mathrm{CFU} / \mathrm{ml}$ for the RotorGene.

Precision of detection in artificially contaminated chicken rinse samples. To evaluate the precision of detection with the two instrument platforms, a range of identical chicken carcass rinse samples were run simultaneously in the same real-time PCR. As shown in Table 1, the SD, $s^{2}$, and CV were low for both the ABI-PRISM and the RotorGene, reflecting a high degree of precision of detection. For the ABI-PRISM the SD and CV ranged from 0.119 to 0.421 and 0.59 to $1.82 \%$, respectively, and for the RotorGene the SD and CV ranged from 0.184 to 0.417 and 0.65 to $2.57 \%$, respectively.

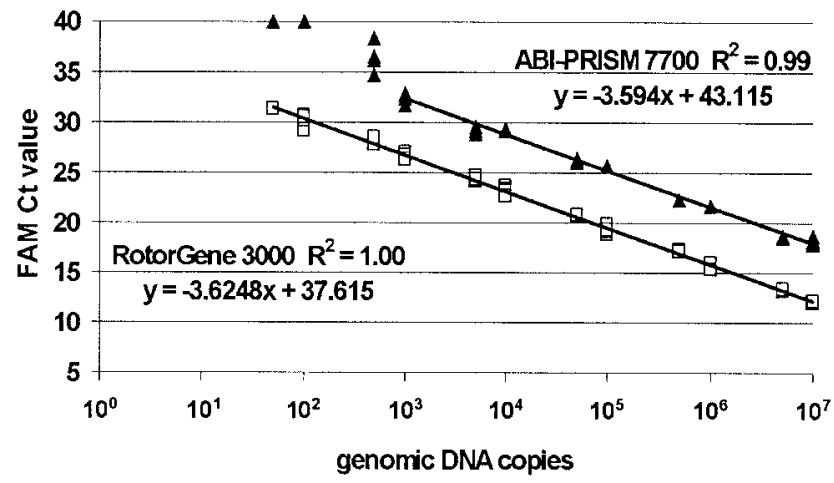

FIG. 2. The linear range of the real-time PCR method when detecting purified DNA from $C$. jejuni CCUG 11284 on the RotorGene $3000\left(5 \times 10^{1}\right.$ to $1 \times 10^{7}$ copies; $\left.\square\right)$ and the ABI-PRISM $7700\left(10^{3}\right.$ to $10^{7}$ copies; $\left.\mathbf{\Delta}\right)$. A real-time PCR sample containing below $5 \times 10^{1}$ genomic DNA copies gave either no positive response or was removed by the detection software because of the $10 \%$ quantification correction on the RotorGene. Levels above $10^{7}$ genomic DNA copies were not tested.

Spiked and naturally contaminated samples. The samples spiked with 0,1 to 10,10 to 100 , and 100 to $1,000 \mathrm{CFU} / 250 \mathrm{ml}$ reached levels of approximately $0,10^{4}, 10^{5}$, and $10^{6} \mathrm{CFU} / \mathrm{ml}$, respectively, after $20 \mathrm{~h}$ of enrichment. PCR detection was possible on both instruments at all spiking levels. However, in general the RotorGene gave lower FAM Ct values than the ABI-PRISM. Based on all spiking levels, the average FAM Ct value was $6 \mathrm{U}$ lower on RotorGene (Table 2).

Thermotolerant campylobacters were found in 40 out of the 66 presumably naturally contaminated chicken rinse samples by the culture-based method. The same 40 culture-positive samples were also found positive with the RotorGene, whereas the ABI-PRISM gave 39 positive responses. The only sample not detected by the ABI-PRISM contained $1.5 \times 10^{2} \mathrm{CFU}$ of thermotolerant campylobacters/ml. There was $100 \%$ agreement between the duplicate responses from the 66 naturally contaminated samples. Figure 4 illustrates the linear correla-

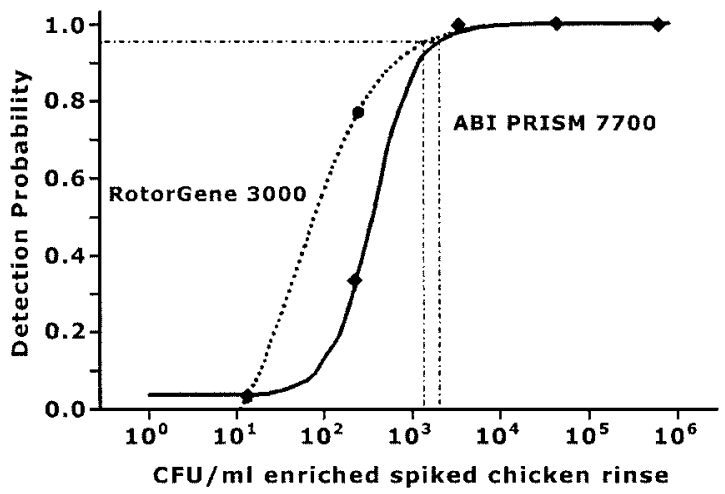

FIG. 3. Detection probability on ABI-PRISM 7700 and RotorGene 3000 for thermotolerant campylobacters with spiked chicken rinse samples containing $10^{1}$ to $10^{6} \mathrm{CFU} / \mathrm{ml}$. Thirty responses for each sample were generated on six separate occasions. Thick dotted line, RotorGene 3000; solid line, ABI-PRISM 7700; intersecting thin dotted lines, $95 \%$ detection probability. The detection probability was determined in the presence of $5 \times 10^{3}$ copies of the IAC. 
TABLE 1. Results from the determination of the precision of detection of $C$. jejuni 1677 in spiked chicken rinse samples ${ }^{a}$

\begin{tabular}{|c|c|c|c|c|c|c|c|c|}
\hline \multirow{2}{*}{$\begin{array}{l}\text { Spiking level } \\
\text { (CFU/250 } \\
\mathrm{ml})\end{array}$} & \multicolumn{4}{|c|}{ ABI-PRISM 7700} & \multicolumn{4}{|c|}{ RotorGene 3000} \\
\hline & $\begin{array}{l}\text { Mean } \mathrm{Ct} \\
\text { value }\end{array}$ & SD & $s^{2}$ & $\begin{array}{l}\mathrm{CV} \\
(\%)\end{array}$ & $\begin{array}{c}\text { Mean } \mathrm{Ct} \\
\text { value }\end{array}$ & SD & $s^{2}$ & $\begin{array}{l}\mathrm{CV} \\
(\%)\end{array}$ \\
\hline 0 & 40 & 0 & 0 & 0 & 40 & 0 & 0 & 0 \\
\hline 0 & 40 & 0 & 0 & 0 & 40 & 0 & 0 & 0 \\
\hline 0 & 40 & 0 & 0 & 0 & 40 & 0 & 0 & 0 \\
\hline $1-10$ & 27.89 & 0.290 & 0.084 & 1.04 & 22.61 & 0.365 & 0.133 & 1.61 \\
\hline $1-10$ & 26.42 & 0.388 & 0.151 & 1.60 & 20.64 & 0.293 & 0.086 & 1.42 \\
\hline $1-10$ & 27.33 & 0.421 & 0.178 & 1.54 & 21.09 & 0.283 & 0.080 & 1.34 \\
\hline $10-100$ & 21.50 & 0.148 & 0.022 & 0.69 & 14.85 & 0.184 & 0.034 & 1.24 \\
\hline $10-100$ & 21.94 & 0.223 & 0.050 & 1.02 & 16.29 & 0.417 & 0.175 & 2.57 \\
\hline 10-100 & 22.61 & 0.261 & 0.068 & 1.15 & 16.51 & 0.371 & 0.138 & 2.25 \\
\hline $100-1,000$ & 19.45 & 0.219 & 0.048 & 1.12 & 13.34 & 0.328 & 0.108 & 2.46 \\
\hline $100-1,000$ & 20.24 & 0.119 & 0.014 & 0.59 & 13.66 & 0.286 & 0.082 & 2.09 \\
\hline $100-1,000$ & 19.64 & 0.358 & 0.128 & 1.82 & 13.46 & 0.296 & 0.088 & 0.65 \\
\hline
\end{tabular}

${ }^{a}$ Samples contained $0,10^{4}, 10^{5}$, and $10^{6} \mathrm{CFU} / \mathrm{ml}$ after enrichment.

tion between the $\mathrm{Ct}$ values for the target probe and the number of CFU in naturally contaminated chicken samples enriched in $\mathrm{BB}$ in both platforms (data available at www.pcr.dk/fig.4.doc). Comparison of real-time PCR with the culture-based method, as applied to the 66 naturally contaminated samples, indicated no difference between the two methods, independent of the real-time platform used. The 26 culture Campylobacter-negative samples all showed a FAM Ct value of 40, while the IAC (VIC) signal was detected in all negative samples. VIC Ct values ranged from 26.9 to 28.1 for the ABI-PRISM and 23.1 to 27.9 for the RotorGene.

Analytical accuracy. No attempt was made to analyze the specificity of the tests, since the primers used previously have been validated against 150 related and nonrelated species (11).

TABLE 2. Results of real-time PCR for detection of food-borne thermotolerant campylobacters on spiked chicken rinse samples tested in duplicate on ABI-PRISM 7700 and RotorGene $3000^{a}$

\begin{tabular}{|c|c|c|c|c|c|c|c|c|}
\hline \multirow{4}{*}{$\begin{array}{l}\text { Level of spiking } \\
\text { (CFU/250 ml) }\end{array}$} & \multicolumn{8}{|c|}{$\mathrm{Ct}$ value for: } \\
\hline & \multicolumn{4}{|c|}{ ABI-PRISM 7700} & \multicolumn{4}{|c|}{ RotorGene 3000} \\
\hline & \multicolumn{2}{|c|}{ Duplicate 1} & \multicolumn{2}{|c|}{ Duplicate 2} & \multicolumn{2}{|c|}{ Duplicate 1} & \multicolumn{2}{|c|}{ Duplicate 2} \\
\hline & FAM & VIC & FAM & VIC & FAM & VIC & FAM & VIC \\
\hline 0 & 40 & 26.5 & 40 & 27.1 & 40 & 27.2 & 40 & 26.9 \\
\hline 0 & 40 & 27.0 & 40 & 27.0 & 40 & 28.4 & 40 & 26.6 \\
\hline 0 & 40 & 26.9 & 40 & 26.7 & 40 & 28.3 & 40 & 26.1 \\
\hline $1-10$ & 27.5 & 27.2 & 27.3 & 26.8 & 21.7 & 26.9 & 22.2 & 26.2 \\
\hline $1-10$ & 26.6 & 29.3 & 25.4 & 26.9 & 20.1 & 26.1 & 18.9 & 26.7 \\
\hline $1-10$ & 26.7 & 27.8 & 25.3 & 26.6 & 19.8 & 26.6 & 20.7 & 25.4 \\
\hline 10-100 & 21.3 & 29.4 & 21.1 & 26.8 & 15.2 & 26.3 & 15.0 & 25.1 \\
\hline 10-100 & 22.2 & 28.9 & 21.2 & 27.6 & 14.7 & 26.0 & 15.5 & 25.0 \\
\hline 10-100 & 22.5 & 28.1 & 21.2 & 26.8 & 16.0 & 26.1 & 15.1 & 25.6 \\
\hline $100-1,000$ & 20.7 & 31.7 & 19.0 & 28.1 & 12.6 & 27.0 & 12.6 & 25.7 \\
\hline $100-1,000$ & 19.5 & 29.7 & 18.6 & 28.4 & 13.0 & 26.3 & 13.1 & 25.5 \\
\hline $100-1,000$ & 20.0 & 27.7 & 19.0 & 28.5 & 13.3 & 26.8 & 12.7 & 28.3 \\
\hline
\end{tabular}

${ }^{a}$ After enrichment the spiked samples contained approximately $0,10^{4}, 10^{5}$, and $10^{6} \mathrm{CFU} / \mathrm{ml}$.

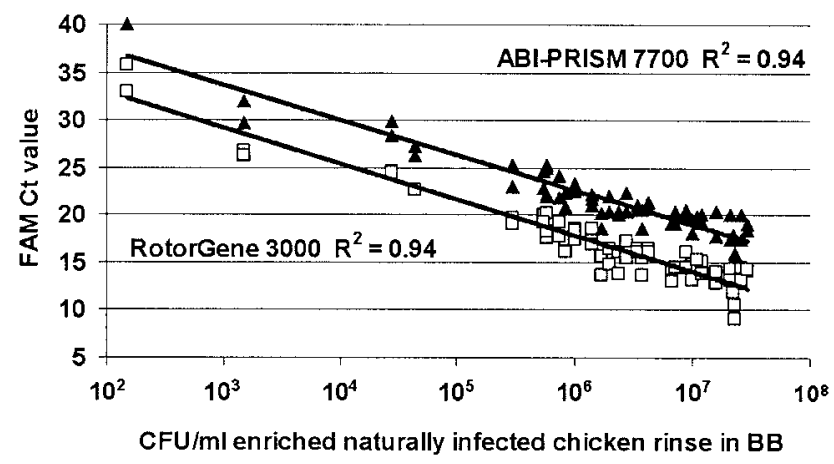

FIG. 4. Linear correlation between target $\mathrm{Ct}$ values and $\mathrm{CFU}$ in naturally contaminated chicken samples enriched in BB. Samples were tested in duplicate on ABI-PRISM $7700(\mathbf{\Delta})$ and RotorGene $3000(\square)$.

A complete "ready-to-go mixture" was stored at $-20^{\circ} \mathrm{C}$ up to 1 month and tested on several occasions against freshly prepared master mixture. DNA material from spiked chicken rinse samples was added to the master mixtures, and the resulting FAM Ct values showed no difference throughout the month (data not shown). Furthermore a protection against carryover contamination was achieved by exchanging $2.5 \mathrm{mM}$ dTTP in the nucleotide mixture with $5 \mathrm{mM}$ dUTP $(12.5 \mathrm{mM}$ nucleotide mixture including dUTP; Applied Biosystems) and $1 / 4 \mathrm{U}$ of heat-labile uracil-DNA glycosylase (Invitrogen $\mathrm{A} / \mathrm{S}$, Tåstrup, Denmark). For genomic DNA this resulted in FAM $\mathrm{Ct}$ values that were between 1 and 3 cycles lower (stronger signal). However, no FAM response was detected for enriched naturally contaminated chicken samples containing less than $4.3 \times 10^{4} \mathrm{CFU} / \mathrm{ml}$ of BB. Adding $7 \%$ (vol/vol) glycerol (Merck, Darmstadt, Germany) to the PCR mixture reestablished the FAM Ct to values identical to levels seen with dTTP (data not shown).

\section{DISCUSSION}

In general, the main advantage of PCR over culture methods is its potential for rapid screening of negative samples. Positive samples, however, still need to be verified by culture to obtain isolates for subtyping, antimicrobial resistance testing, and so on. In contrast to the end point detection by conventional PCR, the real-time PCR provides the opportunity to monitor the accumulation of PCR product during amplification. By generating standard curves from $\mathrm{Ct}$ values from samples of known DNA concentrations, information on the linear range of amplification and amplification efficiency of the assay can be determined (17). These features are important when optimizing the amplification, studying PCR inhibition, and investigating the effect of pre-PCR processing. If a real-time PCR method is intended for quantitative measurements, it is a prerequisite to obtain information on both linear range and amplification efficiency in order to ensure correct quantification. In the present study the amplification efficiency of the realtime PCR assay on the ABI-PRISM (89.9\%) was similar to that on the RotorGene (90.6\%). However, the linear range of amplification was wider on the RotorGene, beginning at $5 \times$ $10^{1}$ copies of genomic DNA compared to the ABI-PRISM linear range, beginning at $10^{3}$ copies. The PCR results (Fig. 4) 
indicate that the method described may be used to estimate the level of Campylobacter in flocks or meat products, although exact quantification requires use of PCR directly on samples without any preenrichment. However, the available technology for sample treatment and DNA extraction does not provide us with a detection limit of 1 CFU per 25-g sample, which is required by international standards.

The limitation in current PCR detection is partly due to loss of Campylobacter during the DNA extraction step and partly due to the low sample volume $(5 \mu \mathrm{l})$ tested. The only publication available on quantitative $C$. jejuni PCR testing of nonenriched chicken samples reports the use of a commercial DNA extraction kit on highly contaminated chicken samples from the Chinese market, containing $>10^{5}$ CFU of Campylobacter/ml before enrichment (20). The Campylobacter contamination level of chicken flocks and chicken products in countries with more-hygienic production methods is known to be much lower, making enrichment of most samples necessary to obtain PCR-detectable results. Cheng and Griffiths have previously observed that a minimum of 100 Campylobacter CFU per $\mathrm{ml}$ is necessary for PCR detection by Triton X-100 DNA extraction. Therefore they used a 12-h enrichment step before PCR detection, although they did not test any naturally contaminated samples (5).

The enrichment followed by real-time PCR data presented here indicates that even chicken flocks with low levels of infection would be detected, in particular by the RotorGene platform. The PCR-based method showed the same responses as the culture-based method, indicating that it is as good as the existing "gold standard." Testing the spiked and naturally contaminated samples on RotorGene resulted in lower FAM Ct values (stronger signal) and produced one more positive result than the ABI-PRISM, reflecting a greater sensitivity of this platform.

The terms sensitivity and detection limit are often used interchangeably in diagnostic PCR and real-time PCR. However, both sensitivity and detection limit can be considerably affected by several factors, including presence of inhibitory substances and quality of DNA. Although a given concentration of cells can be detected by a real-time PCR, it will not necessarily be detected in every real-time PCR. For this reason, the detection limit of any PCR and real-time PCR should always be assessed in association with the detection probability to illustrate the reliability of the assay (17).

In conclusion, the real-time PCR method described seems to be sensitive and robust both for detection and quantification in enriched samples. The method is intended for further validation in an international collaborative trial with regard to standardization.

\section{ACKNOWLEDGMENTS}

This work was supported in part by EC grant no. QLK1-CT-199900226 and by Danish Directorate for Food, Fisheries and Agri Business grant no. 3401-66-03-5.

We thank Mette Skafte Thomsen, and Stefan Jensen for excellent technical assistance, Burkhard Malorny for assistance with preparation of Fig. 3, and Claire Harrington for critical discussions during preparation of the manuscript.

\section{REFERENCES}

1. Anonymous. 2000. Microbiology of food and animal feeding stuffs. Preparation of test samples, initial suspension and decimal dilution for microbiological examination. Part 2. Specific rules for the preparation of the initial suspension and decimal dilutions of meat and meat products. International Standard Organisation ISO/CD 6887-2. AFNOR, Paris, France.

2. Anonymous. 2002. Microbiology of food and animal feeding stuffs. Horizontal method for the detection and enumeration of Campylobacter growing at $41.5^{\circ} \mathrm{C}$. Part 1. Detection method. Document ISO/TC 34/SC 9 N 553, revision 2. Result of voting on ISO/CD 10272-1. International Standard Organisation, Geneva, Switzerland.

3. Anonymous. 2002. Campylobacter. Detection and enumeration of thermotolerant Campylobacter in foods. Draft version. Nordic Committee on Food Analysis, Oslo, Norway.

4. Anonymous. 2002. Microbiology of food and animal feeding stuffs. Polymerase chain reaction (PCR) for the detection of foodborne pathogens. General method specific requirements. Draft International Standard ISO/DIS 22174. DIN, Berlin, Germany.

5. Cheng, Z., and M. W. Griffiths. 2003. Rapid detection of Campylobacter jejuni in chicken rinse water by melting peak analysis of amplicons in realtime polymerase chain reaction. J. Food Prot. 66:1343-1352.

6. Hunt, J. M., C. Abeyta, and T. Tran. January 2001, posting date. Campylobacter. In Bacteriological analytical manual online, 8th ed., revision A. [Online.] http://www.cfsan.fda.gov/ ebam/bam-toc.html. U.S. Food and Drug Administration Washington, D.C.

7. Jensen, A. N., and J. Hoorfar. 2003. Optimal purification and sensitive quantification of DNA from fecal samples. J. Rapid Methods Auto. Microbiol. 10:231-244.

8. Josefsen, M. H., P. S. Lübeck, B. Aalbæk, and J. Hoorfar. 2002. Preston and Park-Sanders protocols adapted for semi-quantitative isolation of thermotolerant campylobacter from chicken rinse. Int. J. Food Microbiol. 80:177183.

9. Knutsson, R., Y. Blixt, H. Grage, E. Borch, and P. Rådström. 2002. Evaluation of selective enrichment PCR procedures for Yersinia enterocolitica. Int. J. Food Microbiol. 73:35-46.

10. Lübeck, P. S. L., P. Wolffs, S. L. W. On, P. Ahrens, P. Rådström, and J. Hoorfar. 2003. Toward an international standard for PCR-based detection of food-borne thermotolerant campylobacters. Part 1. Assay development and analytical validation. Appl. Environ. Microbiol. 69:5664-5669.

11. Lübeck, P. S. L., N. Cook, M. Wagner, P. Fach, and J. Hoorfar. 2003. Toward an international standard for PCR-based detection of food-borne thermotolerant campylobacters. Part 2. Validation of the PCR assay in a multicenter collaborative trial. Appl. Environ. Microbiol. 69:5670-5672.

12. Malorny, B., J. Hoorfar, C. Bunge, and R. Helmuth. 2003. Multicenter validation of the analytical accuracy of Salmonella PCR: towards an international standard. Appl. Environ. Microbiol. 69:290-296.

13. Malorny, B., J. Hoorfar, M. Hugas, A. Heuvelink, P. Fach, L. Ellerbroek, C. Bunge, C. Dorn, and R. Helmut. 2003. Inter-laboratory diagnostic accuracy of a Salmonella-specific PCR-based method. Int. J. Food Microbiol. 89:241249.

14. Nachamkin, I., H. Ung, and M. Li. 2002. Increasing fluoroquinolone resistance in Campylobacter jejuni, Pennsylvania, USA, 1982-2001. Emerg. Infect. Dis. 8:1501-1503.

15. Nogva, H. K., A. Bergh, A. Holck, and K. Rudi. 2000. Application of the 5 '-nuclease PCR assay in evaluation and development of methods for quantitative detection of Campylobacter jejuni. Appl. Environ. Microbiol. 66: 4029-4036.

16. Parkhill, J., B. W. Wren, K. Mungall, J. M. Ketley, C. Churcher, D. Basham, T. Chillingworth, R. M. Davies, T. Feltwell, S. Holroyd, K. Jagels, A. V. Karlyshev, S. Moule, M. J. Pallen, C. W. Penn, M. A. Quail, M.-A. Rajandream, K. M. Rutherford, A. H. M. van Vliet, S. Whitehead, and B. G. Barrell. 2000. The genome sequence of the food-borne pathogen Campylobacter jejuni reveals hypervariable sequences. Nature 403:665-668.

17. Rådström, P., C. Löfstöm, M. Lövenklev, R. Knutsson, and P. Wolffs. 2003. Strategies for overcoming PCR inhibition, p. 149-161. In C. W. Dieffenbach and G. S. Dveksler (ed.), PCR primer: a laboratory manual, 2nd ed. Cold Spring Harbor Laboratory Press, Cold Spring Harbor, N.Y.

18. Sails, A. D., A. J. Fox, F. J. Bolton, D. R. A. Wareing, and D. L. A. Greenway. 2003. A real-time PCR assay for the detection of Campylobacter jejuni in foods after enrichment culture. Appl. Environ. Microbiol. 69:1383-1390.

19. Solomon, E. B., and D. G. Hoover. 1999. Campylobacter jejuni: a bacterial paradox. J. Food Safety 19:121-136.

20. Yang, C., Y. Jiang, K. Huang, C. Zhu, and Y. Yin. 2003. Application of real-time PCR for quantitative detection of Campylobacter jejuni in poultry, milk and environmental water. FEMS Immnol. Med. Microbiol. 38:265-271. 
Comparative, collaborative, and on-site validation of a TaqMan PCR method as a tool for certified production of fresh, Campylobacter-free chickens. Krause, M., M.H. Josefsen, M. Lund, N.R. Jacobsen, L. Brorsen, M. Moos, A. Stockmarr, and J. Hoorfar.

Applied and Environmental Microbiology (2006) 72:5463-5468. 


\title{
Comparative, Collaborative, and On-Site Validation of a TaqMan PCR Method as a Tool for Certified Production of Fresh, Campylobacter-Free Chickens
}

\author{
M. Krause, ${ }^{1}$ M. H. Josefsen, ${ }^{1}$ M. Lund,${ }^{1}$ N. R. Jacobsen, ${ }^{1}$ L. Brorsen, ${ }^{2}$ M. Moos, ${ }^{2}$ \\ A. Stockmarr, ${ }^{1}$ and J. Hoorfar ${ }^{1 *}$ \\ Danish Institute for Food and Veterinary Research, 27 Bülowsvej, 1790 Copenhagen, Denmark, ${ }^{1}$ \\ and Danpo, 3 Vestre Skovvej, 9600 Aars, Denmark ${ }^{2}$
}

Received 6 February 2006/Accepted 11 June 2006

\begin{abstract}
Certified Campylobacter-free poultry products have been produced in Denmark since 2002, the first example of fresh (unprocessed and nonfrozen) chickens labeled "Campylobacter free." This success occurred partly through use of a 4-hour gel-based PCR testing scheme on fecal swabs. In this study, a faster, real-time PCR approach was validated in comparative and collaborative trials, based on recommendations from the Nordic system for validation of alternative microbiological methods (NordVal). The comparative real-time PCR trial was performed in comparison to two reference culture protocols on naturally contaminated samples $(99$ shoe covers, 101 cloacal swabs, 102 neck skins from abattoirs, and 100 retail neck skins). Culturing included enrichment in both Bolton and Preston broths followed by isolation on Preston agar and mCCDA. In one or both culture protocols, 169 samples were identified as positive. The comparative trial resulted in relative accuracy, sensitivity, and specificity of $\mathbf{9 8 \%}, \mathbf{9 5 \%}$, and $\mathbf{9 7 \%}$, respectively. The collaborative trial included nine laboratories testing neck skin, cloacal swab, and shoe cover samples, spiked with low, medium, and high concentrations of Campylobacter jejuni. Valid results were obtained from six of the participating laboratories. Accuracy for high levels was $\mathbf{1 0 0 \%}$ for neck skin and cloacal swab samples. For low levels, accuracy was $\mathbf{1 0 0 \%}$ and $92 \%$ for neck skin and cloacal swab samples, respectively; however, detection in shoe cover samples failed. A second collaborative trial, with an optimized DNA extraction procedure, gave $100 \%$ accuracy results for all three spiking levels. Finally, on-site validation at the abattoir on a flock basis was performed on 400 samples. Real-time PCR correctly identified 10 of 20 flocks as positive; thus, the method fulfilled the NordVal validation criteria and has since been implemented at a major abattoir.
\end{abstract}

Human campylobacteriosis is a widespread zoonotic foodborne infection (9). The majority of infections are sporadic and the sources rarely determined (20). Humans can be infected by eating insufficiently cooked meat products (poultry, pork, and beef), by drinking raw milk and polluted water, and by coming into contact with pets (2). A Danish case-control study has identified consumption of undercooked poultry as one of the main causes of human infections (19). In 2003, approximately $35 \%$ of Danish broiler flocks were infected with Campylobacter jejuni (6).

Rapid detection methods are an important part of any intervention strategy, which may also include separating Campylobacter-positive from Campylobacter-negative flocks at slaughter. The production of certified, fresh Campylobacter-free poultry products has been taking place in Denmark since 2002 and is the world's first example of fresh chickens labeled for sale as being "Campylobacter free." This certification has been based on a conventional gel electrophoresis PCR. In general, the superiority of PCR testing lies in its ability to detect the pathogen in cloacal swab samples within the same working shift, making it possible to slaughter chicken flocks with a known Campylobacter-negative status before dealing with positive flocks. The purpose of the present study was to validate a

\footnotetext{
* Corresponding author. Mailing address: Danish Institute for Food and Veterinary Research, 27 Bülowsvej, DK-1790 Copenhagen V, Denmark. Phone: 45-72346251. Fax: 45-72346001. E-mail: jho@dfvf.dk.
}

newly developed TaqMan PCR method (12) in comparative and collaborative trials according to the recommendations of the Nordic validation organization, NordVal (5). The PCR method used includes an internal amplification control (IAC), reinforcing its value as a diagnostic tool.

The comparative validation was performed against two reference culture methods, applying different combinations of selective enrichment media and selective plating media. To our knowledge, none of the published, noncommercial, real-time PCR methods for the detection of thermotolerant Campylobacter have been evaluated through a collaborative trial (17, $21,22,23,24)$. It is essential for routine application that an analytical method is reliable and consistent. To establish these features, extensive testing of the robustness and performance characteristics of the method is required, preferably through a collaborative trial, including end-use laboratories (10) and onsite on a flock basis.

\section{MATERIALS AND METHODS}

Comparative study. The Preston broth was prepared according to the recommendations of the Nordic Committee on Food Analysis (1). Briefly, $25 \mathrm{~g}$ of nutrient broth no. 2 (catalog no. CM67; Oxoid, Basingstoke, United Kingdom) was dissolved in $1,000 \mathrm{ml}$ of distilled water, autoclaved for $15 \mathrm{~min}$ at $121^{\circ} \mathrm{C}$, and, after cooling to $50^{\circ} \mathrm{C}$, was combined aseptically with a mixture of $50 \mathrm{ml}$ lysed horse blood (Danish Institute for Food and Veterinary Research [DFVF], Copenhagen, Denmark), $4 \mathrm{ml}$ of modified Preston Campylobacter selective supplement (catalog no. SR204E; Oxoid), and $4 \mathrm{ml}$ of Campylobacter growth supplement (catalog no. SR084E; Oxoid). 
The Bolton broth was prepared according to the manufacturer's recommendations. Briefly, $13.8 \mathrm{~g}$ of Bolton broth (catalog no. CM0983; Oxoid) was dissolved in $500 \mathrm{ml}$ of distilled water, autoclaved for $15 \mathrm{~min}$ at $121^{\circ} \mathrm{C}$, and, after cooling to $50^{\circ} \mathrm{C}$ was combined aseptically with a mixture of $25 \mathrm{ml}$ lysed horse blood (DFVF) and one vial of Bolton broth selective supplement (SR0183E) reconstituted as directed.

The modified charcoal cefoperazone deoxycholate agar (mCCDA) was prepared according to the manufacturer's recommendations. Briefly, $45.5 \mathrm{~g}$ of Campylobacter blood-free selective agar (catalog no. CM0739; Oxoid) was suspended in $1,000 \mathrm{ml}$ of distilled water and brought to boil to dissolve completely. The agar was autoclaved at $121^{\circ} \mathrm{C}$ for $15 \mathrm{~min}$ and, after cooling to $50^{\circ} \mathrm{C}$, was combined aseptically with two vials of CCDA selective supplement (catalog no. SR0155; Oxoid) reconstituted twice with $2 \mathrm{ml}$ sterile distilled water.

The Preston agar was prepared according to the manufacturer's recommendations. Briefly, $18.5 \mathrm{~g}$ of Campylobacter agar base (catalog no. CM0689; Oxoid) was suspended in $475 \mathrm{ml}$ of distilled water and brought to boil to dissolve completely. The agar was autoclaved at $121^{\circ} \mathrm{C}$ for $15 \mathrm{~min}$, and after cooling to $50^{\circ} \mathrm{C}$ was combined with a mixture of $25 \mathrm{ml}$ lysed horse blood (DFVF) and one vial of Preston Campylobacter selective supplement (catalog no. SR0117; Oxoid) reconstituted with $2 \mathrm{ml}$ of 50/50 acetone/sterile distilled water.

The brain heart infusion medium (BHI) was prepared according to the manufacturer's recommendations and consisted of $37 \mathrm{~g} /$ liter BHI (Difco, Sparks, MD) with $5 \%(\mathrm{vol} / \mathrm{vol})$ calf blood (DFVF) and $0.5 \%$ agar added.

Campylobacter real-time PCR. Real-time TaqMan PCR was performed in a RotorGene 3000 (Corbett Research, Australia) in 0.2-ml PCR tubes as described previously (12), except for the addition of $2.0 \mu \mathrm{l} /$ reaction of $87 \%$ pure glycerol (Merck A/S, Denmark) and $1.0 \mu \mathrm{l} /$ reaction of $12.5 \mathrm{mM}$ dNTP mix with dUTP (Applied Biosystems, Foster City, CA), enabling uracil- $N$-glycosylase treatment to prevent carryover contamination. Each PCR analysis included a positive DNA control, a negative DNA control, a nontemplate control (NTC), and an IAC. The cutoff level and definition of positive/negative responses were exactly as described previously (12). Samples with a threshold cycle $\left(C_{T}\right)$ response below 40 were considered to be positive.

Sampling. As shown in Table 1, the following samples were collected in Denmark: 99 pooled fecal samples on shoe covers from rearing houses, 101 cloacal swab samples from an abattoir, 102 samples of neck skin from an abattoir, and 100 samples of neck skin from the retail sector. The shoe cover, cloacal swab, and neck skin samples from the abattoir originated from flocks at 34 different farms. Approximately half of the samples were taken in the spring, when the prevalence of Campylobacter spp. in chicken flocks is expected to be low in Denmark (approximately 20\%), and the other half were taken in the early autumn, when the prevalence is expected to be high (approximately 60\%). Approximately half of the neck skin samples from the retailers were taken from chicken flocks that were reported to be Campylobacter positive by the supplier, and the other half from flocks that had tested negative.

Sample preparation. Fecal samples were collected on disposable shoe covers in the rearing houses and shipped at ambient temperature to DFVF. On arrival, the shoe cover samples were weighed and added to $1: 10(\mathrm{wt} / \mathrm{vol})$ physiological saline and homogenized for $60 \mathrm{~s}$ in a stomacher.

The cloacal swab samples were taken at the abattoir from 12 or 13 individual broilers on arrival at the abattoir. The swabs were stored in tightly capped $15-\mathrm{ml}$ plastic tubes with BHI and shipped to DFVF. On arrival, 20 samples were pooled into 1 sample and homogenized manually in $30 \mathrm{ml}$ physiological saline for $60 \mathrm{~s}$. Because of the high background flora in the fecal samples, growth during transportation (one day) was regarded as insignificant to the outcome of the test.

Approximately $40 \mathrm{~g}$ of chicken neck skin was cut and pooled into a plastic bag at the slaughter line. The samples were transferred to a stomacher bag, sealed, and shipped on ice packs to DFVF by mail. On arrival, the samples were diluted 1:1 in physiological saline and homogenized for $60 \mathrm{~s}$ in a stomacher.

For retail samples, fresh (nonfrozen) chickens were purchased; $40 \mathrm{~g}$ neck skin was cut at the laboratory and diluted 1:1 in physiological saline and homogenized for $60 \mathrm{~s}$ in a stomacher.

Reference culture methods. The detection of Campylobacter spp. was conducted in accordance with the recommendations from the Nordic Committee on Food Analyses (1) and the International Organization for Standardization (3). All samples were enriched in Bolton and Preston broths $(1: 10)$ at $42 \pm 0.5^{\circ} \mathrm{C}$ in a microaerobic atmosphere $\left(6 \% \mathrm{O}_{2}, 7 \% \mathrm{CO}_{2}, 7 \% \mathrm{H}_{2}\right.$, and $\left.80 \% \mathrm{~N}_{2}\right)$ for $24 \mathrm{~h}$ before $100 \mu \mathrm{l}$ was plated onto Preston agar and mCCDA. The agar plates were incubated at $42 \pm 0.5^{\circ} \mathrm{C}$ in a microaerobic atmosphere for $48 \mathrm{~h}$. From the selective agar, five typical thermotolerant Campylobacter colonies were selected for verification by an internationally validated gel-based PCR assay for the identification of Campylobacter jejuni, C. coli, and C. lari $(15,16)$. In the absence of typical colonies, five nontypical colonies were selected for PCR verification.
DNA extraction by magnetic beads. From the fecal sample suspensions (cloacal swabs and shoe covers), 1-ml aliquots were drawn for DNA extraction before enrichment. From the neck skin samples, 1-ml aliquots were drawn for DNA extraction after overnight enrichment in Bolton broth. The samples were centrifuged at $16,000 \times g$ for $7 \mathrm{~min}$ at $4^{\circ} \mathrm{C}$, and DNA extraction was performed on a KingFisher processor (Thermo Lab Systems, Helsinki, Finland) using an automated, magnetically based separation and DNA isolation kit for blood, cells, and tissue (Thermo Lab Systems) as specified by the manufacturer. Briefly, the sample pellet was resuspended in lysis buffer and transferred to a 96-well plate (Thermo Lab Systems) containing magnetic particles, washing buffers, and elution buffer. The DNA extraction program consisted of two salt-buffer washing steps and two alcohol-buffer washing steps, followed by a final elution step (for a detailed protocol, see the Rapid Diagnostic Group website [http://www.pcr.dk /Innovations_pcr/innovations_pcr_startside.htm]). A total of $5 \mu$ l of the extracted DNA was used as the template in the real-time PCR.

Statistical data analysis. The comparative validation study included three test characteristics: relative accuracy, sensitivity, and specificity (5) (see Table 2). The relative accuracy is defined as the degree of correspondence between the response obtained by the alternative method and the reference method on identical samples, as follows: $(\mathrm{PA}+\mathrm{NA}+\mathrm{FP}) \times 100 /(\mathrm{PA}+\mathrm{NA}+\mathrm{TP}+\mathrm{FN}+\mathrm{FP})$, where PA refers to positive agreement, NA to negative agreement, FP to false positives, TP to true positives, and FN to false negatives. The relative sensitivity is defined as the ability of the alternative method to detect the target microorganism compared to the reference method, as follows: $(\mathrm{PA}+\mathrm{TP}) \times 100 /(\mathrm{PA}+$ FN). The relative specificity is defined as the ability of the alternative method not to detect the target microorganism when it is not detected by the reference method, as follows: $(\mathrm{NA} \times 100) /(\mathrm{NA}+\mathrm{FP})$.

To compare the performances of Bolton and Preston broths, the number of positive responses obtained from each was subtracted, giving one difference for each combination of sample type and agar type. The Wilcoxon signedrank test with a continuity correction was applied to these differences to test whether the two enrichment broths differed significantly from each other (14). The calculations where performed using Splus software, professional edition version 6.1 .

Collaborative trial. A collaborative trial involving nine national laboratories was performed to evaluate the robustness and reproducibility of the real-time PCR method testing identical samples.

The collaborative trial was designed and conducted according to the recommendations from NordVal (5). The nine participating laboratories received pellets from 18 coded 1-ml samples, including 6 chicken neck skin samples, 6 shoe cover samples, and 6 cloacal swab samples (see Table 3). The samples were spiked in duplicate with C. jejuni CCUG 11284 at three levels, making it possible to assess the usefulness of the method at various infection levels. The shipment included a positive DNA control $(1 \mu \mathrm{g} / \mathrm{ml}$ C. jejuni CCUG 11284) and a negative DNA control (1 $\mu \mathrm{g} / \mathrm{ml}$ Arcobacter butzleri CCUG 30485), a ready-to-use PCR mixture with added IAC, and reagents for the magnetically based DNA extraction. To minimize any interlaboratory variability (not attributable to the method performance), we supplied all the reagents necessary. Each participant received a detailed protocol describing the DNA extraction, real-time PCR setup, realtime PCR run, and data analysis and a reporting form to record the obtained PCR results to return to DFVF. The participants were also asked to return a file containing the real-time PCR runs.

A second collaborative trial, comprising eight participating laboratories, was subsequently performed only on shoe cover samples. The second trial was performed exactly as the first one, except for using a modified DNA extraction protocol, with an increased amount of paramagnetic particles.

Samples. The samples for the collaborative trial were prepared as described above ("Sample preparation"). Regarding the neck skin samples, one broth was left unspiked, one was spiked with 1 to $10 \mathrm{CFU} / 100 \mathrm{ml}$, and one with 10 to 100 $\mathrm{CFU} / 100 \mathrm{ml}$, and incubated at $42 \pm 0.5^{\circ} \mathrm{C}$ for $24 \mathrm{~h}$ in a microaerobic atmosphere. After the enrichment, 1-ml aliquots were drawn and centrifuged at $16,000 \times g$ for $7 \mathrm{~min}$ at $4^{\circ} \mathrm{C}$. The supernatant was discarded, and the pellet kept at $-80^{\circ} \mathrm{C}$ until shipped on ice to the trial participants.

From both shoe cover and cloacal swab samples, 1-ml aliquots were drawn, spiked with 0,100 to 500 , or 1,000 to $2,000 \mathrm{CFU} / \mathrm{ml}$, and centrifuged at $16,000 \times$ $g$ for $7 \mathrm{~min}$ at $4^{\circ} \mathrm{C}$. The supernatant was discarded and the pellet kept at $-80^{\circ} \mathrm{C}$ until shipped on ice to the trial participants.

The Campylobacter status of all samples was confirmed at DFVF by the reference culture method according to International Organization for Standardization publication no. 10272-1 (3) and Nordic Committee on Food Analyses publication no. 119 (1) prior to and after spiking. The stability of the samples was examined using real-time PCR (12) immediately after spiking, prior to commencement of the collaborative trial, and during the period of analysis, to verify 
TABLE 1. Samples from the chicken production chain with positive isolates of thermotolerant Campylobacter

\begin{tabular}{|c|c|c|c|c|c|c|}
\hline \multirow{3}{*}{ Sample source } & \multirow{3}{*}{$\begin{array}{l}\text { No. of } \\
\text { samples }\end{array}$} & \multicolumn{5}{|c|}{$\begin{array}{l}\text { No. of Campylobacter-positive samples in } \\
\text { indicated medium on indicated plate type }\end{array}$} \\
\hline & & \multirow[b]{2}{*}{ Total $^{a}$} & \multicolumn{2}{|c|}{ Bolton broth } & \multicolumn{2}{|c|}{ Preston broth } \\
\hline & & & $\begin{array}{c}\text { Preston } \\
\text { agar }\end{array}$ & $\mathrm{mCCDA}$ & $\begin{array}{l}\text { Preston } \\
\text { agar }\end{array}$ & mCCDA \\
\hline Shoe covers & 99 & 22 & 21 & 22 & 20 & 21 \\
\hline Cloacal swabs & 101 & 44 & 40 & 42 & 37 & 43 \\
\hline Neck skins from: & & & & & & \\
\hline Abattoir & 102 & 46 & 46 & 46 & 42 & 46 \\
\hline Retailers & 100 & 57 & 57 & 57 & 57 & 57 \\
\hline Total & 402 & 169 & 164 & 167 & 156 & 167 \\
\hline
\end{tabular}

${ }^{a}$ Total number isolated from at least one of the four agar plates.
TABLE 2. Comparison of the results obtained by the real-time PCR and the reference culture methods

\begin{tabular}{|c|c|c|c|c|c|c|c|c|c|}
\hline \multirow{2}{*}{ Matrix } & \multicolumn{6}{|c|}{$\begin{array}{l}\text { No. of samples with } \\
\text { indicated result }\end{array}$} & \multicolumn{3}{|c|}{$\%$ Value $^{b}$} \\
\hline & PA & NA & FN & TP & FP & Total & Accuracy & Sensitivity & Specificity \\
\hline Shoe covers & 18 & 73 & 4 & 0 & 4 & 99 & 96 & 82 & 95 \\
\hline Cloacal swabs & 39 & 55 & 5 & 0 & 2 & 101 & 95 & 88 & 96 \\
\hline \multicolumn{10}{|l|}{$\begin{array}{l}\text { Neck skins } \\
\text { from: }\end{array}$} \\
\hline Abattoir & 46 & 55 & 0 & 0 & 1 & 102 & 100 & 100 & 98 \\
\hline Retailers & 57 & 43 & 0 & 0 & 0 & 100 & 100 & 100 & 100 \\
\hline Total & 160 & 226 & 9 & 0 & 7 & 402 & 98 & 95 & 97 \\
\hline
\end{tabular}

${ }^{a} \mathrm{PA}$, positive agreement; NA, negative agreement; TP, true positive; FN, false negative; FP, false positive.

${ }_{b}^{b}$ See Materials and Methods for accuracy, sensitivity, and specificity formulas.

Applying Preston broth followed by Preston agar resulted in 156 samples being found positive. The obtained $P$ value was 0.32 , indicating no significant difference between the Bolton and Preston broths.

A total of 167 out of 402 samples gave positive results by real-time PCR, compared to a total of 169 by the culture methods. Nine false-negative and 7 false-positive results were obtained by the real-time PCR method. This resulted in a relative accuracy of $98 \%$, a relative sensitivity of $95 \%$, and a relative specificity of $97 \%$ (Table 2 ).

Collaborative trial. In agreement with the predefined criteria, results from three laboratories were excluded because of obvious deviation from the protocol. The results from the remaining laboratories were accepted; thus, the final statistical analysis was performed on six sets of results (Table 3 ).

The relative specificity, sensitivity, and accuracy were $100 \%$ in the testing of neck skin samples. In the testing of cloacal swab samples, a relative specificity of $100 \%$ was obtained. A relative sensitivity of $92 \%$ was achieved for cloacal swab samples spiked with 100 to $500 \mathrm{CFU} / \mathrm{ml}$, and $100 \%$ for the samples spiked with the higher levels, i.e., 1,000 to 2,000 CFU/ml (Table 4).

The real-time PCR method failed to detect any of the shoe cover samples, regardless of the level of spiking, except for one positive signal obtained from a sample spiked with 100 to 500 $\mathrm{CFU} / \mathrm{ml}$.

In the second collaborative trial on shoe cover samples, results from all eight participating laboratories were included in the statistical analysis. Only results from six laboratories are shown in Table 3. The relative specificity, sensitivity, and accuracy for shoe cover samples were $94 \%, 100 \%$, and $100 \%$, respectively (Table 4).

Validation at abattoir. Table 5 shows the real-time PCR results obtained, compared to those from a routinely used gel-based PCR approved by the Danish authorities. The realtime PCR was performed at the testing laboratory of one of the major poultry producers in Denmark. The real-time PCR method correctly identified 10 out of 10 Campylobacter-positive chicken flocks and 10 out of 10 Campylobacter-negative chicken flocks. 
TABLE 3. Collaborative trial: real-time PCR results for the detection of thermotolerant Campylobacter spp. in spiked samples from chickens ${ }^{a}$

\begin{tabular}{|c|c|c|c|c|c|c|c|c|c|c|c|c|c|c|c|c|c|c|}
\hline \multirow{3}{*}{$\begin{array}{l}\text { Level of } \\
\text { spiking }^{b}\end{array}$} & \multicolumn{18}{|c|}{$C_{T}$ values for replicates from indicated source (by participant no.) } \\
\hline & \multicolumn{6}{|c|}{ Neck skins } & \multicolumn{6}{|c|}{ Shoe covers } & \multicolumn{6}{|c|}{ Cloacal swabs } \\
\hline & 1 & 2 & 3 & 4 & 5 & 6 & 1 & 2 & 3 & 4 & 5 & 6 & 1 & 2 & 3 & 4 & 5 & 6 \\
\hline None & 40,40 & 40,40 & 40,40 & 40,40 & 40,40 & 40,40 & 40,29 & 40,40 & 40,40 & 40,40 & 40,40 & 40,40 & 40,40 & 40,40 & 40,40 & 40,40 & 40,40 & 40,40 \\
\hline Low & 35,34 & 26,25 & 33,32 & 27,26 & 27,26 & 28,28 & 26,26 & 25,26 & 26,26 & 20,22 & 27,26 & 28,27 & 38,33 & 28,28 & 39,40 & 30,31 & 36,38 & 31,31 \\
\hline High & 34,29 & 20,22 & 30,29 & 22,23 & 21,21 & 23,23 & 24,23 & 23,23 & 23,23 & 18,18 & 24,24 & 25,23 & 35,31 & 24,25 & 34,36 & 26,26 & 27,29 & 29,29 \\
\hline
\end{tabular}

${ }^{a}$ This table includes only results from participants that were not excluded due to obvious deviation from the trial protocol.

${ }^{b}$ Low, 1 to $10 \mathrm{CFU}$ for neck skin and 100 to $500 \mathrm{CFU}$ for shoe covers and cloacal swabs; high, 10 to $100 \mathrm{CFU}$ for neck skin and 1,000 to $2,000 \mathrm{CFU}$ for shoe covers and cloacal swabs.

\section{DISCUSSION}

Enrichment in selective broth will always be a compromise between the inhibition of competitive flora and the recovery and growth of the target microorganism. The results of the present study did not detect any difference $(P=0.32)$ in the ability of Preston and Bolton broth to support growth of Campylobacter. Martin et al. reached the same conclusion, testing 100 samples of chicken meat, sausage meat, pig offal, unpasteurized milk, and untreated water (18). However, these results differ from the findings of Baylis et al., who found Bolton broth superior to Preston broth, testing 100 raw foods, including chicken carcass, chicken meat, chicken liver, turkey, duck, beef, lamb liver, and pork sausage meat (7). In opposite findings, Borck et al. reported that Preston broth was better in tests of 41 turkey neck skin samples enriched in Preston broth and Campylobacter enrichment broth (same formula as Bolton broth) (8). Finally, Josefsen et al. have shown in a comprehensive study that Bolton broth and Preston broth equally support the growth of $C$. jejuni, while Preston broth was less effective in supporting the growth of Campylobacter coli (13). These differences in results can be attributed to the matrices and the background flora of the samples; thus, the two enrichment broths can be used equally for routine testing.

Comparative study. In the comparative study, the divergence in the number of negative results between the culture method and real-time PCR could be ascribed to the fact that in the present study, the fecal samples were enriched in Bolton and Preston broths for $24 \mathrm{~h}$ and consequently grown to a high concentration of Campylobacter spp. in the culture method. Real-time PCR, however, was performed directly on the fecal samples without any preceding enrichment. Seven samples were identified as positive by real-time PCR but were identi-

TABLE 4. Validation parameters obtained by the real-time PCR method on spiked chicken samples based on the results obtained in the collaborative trial

\begin{tabular}{|c|c|c|c|c|c|c|}
\hline \multirow{3}{*}{ Matrix } & \multicolumn{6}{|c|}{$\%$ Value for indicated level of spiking ${ }^{a}$} \\
\hline & \multirow{2}{*}{$\begin{array}{l}\text { Specificity } \\
\text { (no spiking) }\end{array}$} & \multicolumn{2}{|c|}{ Sensitivity } & \multicolumn{3}{|c|}{ Accuracy } \\
\hline & & Low & High & $\begin{array}{c}\text { No } \\
\text { spiking }\end{array}$ & Low & High \\
\hline Neck skins & 100 & 100 & 100 & 100 & 100 & 100 \\
\hline Shoe covers & 94 & 100 & 100 & 100 & 100 & 100 \\
\hline Cloacal swabs & 100 & 92 & 100 & 100 & 92 & 100 \\
\hline
\end{tabular}

${ }^{a}$ Low, 1 to $10 \mathrm{CFU}$ for neck skin and 100 to $500 \mathrm{CFU}$ for shoe covers and cloacal swabs; high, 10 to $100 \mathrm{CFU}$ for neck skin and 1,000 to 2,000 CFU for shoe covers and cloacal swabs. fied as negative using the culture method. This difference may be attributable to the presence of Campylobacter spp. that were viable but not culturable or dead in these samples.

Collaborative study. In the first collaborative study, complete agreement between the real-time PCR method and the microbiological reference method was obtained for all test characteristics for neck skin samples. Compared to the reference culture method, real-time PCR detected 11 out of the 12 cloacal swab samples spiked with the target microorganism at a low level, corresponding to a $92 \%$ relative sensitivity. However, the level of thermotolerant Campylobacter in fecal samples from infected chicken flocks is usually in the range of 4 to $8 \log _{10} \mathrm{CFU} / \mathrm{g}$ feces and will most probably be between 5.5 and $6.5 \log _{10} \mathrm{CFU} / \mathrm{g}$ feces (22). The number of CFU to be analyzed in a 1-ml sample by the real-time method is estimated to be $2 \times$ $10^{4}$ to $2 \times 10^{5} \mathrm{CFU}$.

TABLE 5. On-site results of the real-time PCR method on cloacal swabs, validated against an approved gel-based $\mathrm{PCR}^{a}$

\begin{tabular}{|c|c|c|c|}
\hline \multirow[b]{2}{*}{ Flock no. } & \multirow{2}{*}{$\begin{array}{l}\text { No. of samples } \\
\text { positive by gel } \\
\text { PCR/total no. } \\
\text { of samples }\end{array}$} & \multicolumn{2}{|c|}{ Real-time PCR } \\
\hline & & $\begin{array}{c}\text { No. of samples } \\
\text { positive/total } \\
\text { no. of samples }\end{array}$ & $C_{T}$ value(s) \\
\hline \multicolumn{4}{|c|}{$\begin{array}{l}\text { Campylobacter- } \\
\text { positive flocks }\end{array}$} \\
\hline 1 & $19 / 20$ & $19 / 20$ & $27-31$ \\
\hline 2 & $20 / 20$ & $20 / 20$ & $18-30$ \\
\hline 3 & $20 / 20$ & $20 / 20$ & $17-23$ \\
\hline 4 & $16 / 20$ & $20 / 20$ & $18-30$ \\
\hline 5 & $20 / 20$ & $20 / 20$ & $17-27$ \\
\hline 6 & $1 / 20$ & $1 / 20$ & 32 \\
\hline 7 & $20 / 20$ & $20 / 20$ & $18-22$ \\
\hline 8 & $8 / 20$ & $11 / 20$ & $23-39$ \\
\hline 9 & $20 / 20$ & $20 / 20$ & $18-25$ \\
\hline 10 & $19 / 20$ & $19 / 20$ & $17-24$ \\
\hline \multicolumn{4}{|c|}{$\begin{array}{l}\text { Campylobacter- } \\
\text { negative flocks }\end{array}$} \\
\hline 11 & $0 / 20$ & $0 / 20$ & $>40$ \\
\hline 12 & $0 / 20$ & $0 / 20$ & $>40$ \\
\hline 13 & $0 / 20$ & $0 / 20$ & $>40$ \\
\hline 14 & $0 / 20$ & $0 / 20$ & $>40$ \\
\hline 15 & $0 / 20$ & $0 / 20$ & $>40$ \\
\hline 16 & $0 / 20$ & $0 / 20$ & $>40$ \\
\hline 17 & $0 / 20$ & $0 / 20$ & $>40$ \\
\hline 18 & $0 / 20$ & $0 / 20$ & $>40$ \\
\hline 19 & $0 / 20$ & $0 / 20$ & $>40$ \\
\hline 20 & $0 / 20$ & $0 / 20$ & $>40$ \\
\hline
\end{tabular}

${ }^{a}$ The microbiological status of the flocks was confirmed previously by a reference culture method. 
The considerable difference in the $C_{T}$ values observed among the participating laboratories (Table 3) for the same samples can be attributed to variation in the sensitivity of the real-time PCR platforms used. It has been shown that transferring a PCR method from one type of real-time instrument to another can result in a substantial shift in $C_{T}$ values (12).

In the first collaborative trial, the real-time PCR method failed to detect any of the shoe cover samples regardless of the level of spiking. Detection of $C$. jejuni in the shoe cover samples was possible at our laboratory at both low and high spiking levels. Posttrial investigations have shown that the reason for this discrepancy lies with the DNA extraction procedure. The extraction protocol provided to the participating laboratories was modified for compatibility with several DNA extraction platforms, and this approach resulted in a markedly reduced amount of total DNA recovery. The shoe cover samples can be more PCR inhibitory and yield less DNA than the other sample matrices, and it is likely that these features were the cause of the absence of positive signals.

In the second collaborative trial, the amount of paramagnetic particles was more than tripled, rectifying the problem with DNA extraction from this matrix. Shoe cover samples contain substantial amounts of extraneous material, and the results indicate that clotting of the magnetic particles hindered the absorption of DNA.

A relative specificity of $94 \%$ was obtained for shoe cover samples in the second collaborative trial, since one laboratory obtained a positive signal from one of the nonspiked samples (Table 3). This unexpected result could be due to cross contamination during DNA extraction or miscoding of the sample at DFVF.

The samples tested in the collaborative study were not naturally infected. Because the concentrations of the target microorganism in naturally infected samples are unknown, it would have been difficult to assess the method performance on samples with low levels of thermotolerant Campylobacter spp.

Validation at abattoir. The on-site, flock-based validation of real-time PCR at the abattoir against an existing conventional gel-PCR method was successful. It should be noted that the Campylobacter status of the flocks had been previously determined by a reference culture method (1) on shoe cover samples from the rearing houses. This practice allows the poultry manufacturer to perform separated slaughtering. Pooled cloacal swab samples are taken out immediately after the killing and tested to determine the Campylobacter status of the chicken flocks and subsequently to label and mark the chickens as being Campylobacter free in accordance with Danish regulations. The regulation states that if one or more of the 20 pooled samples are Campylobacter positive, the whole flock should be regarded as being positive. Although some minor variations were seen in single samples, the results from the conventional gel-based PCR and the microbiological history of the flocks confirmed the real-time PCR results, emphasizing that the faster and less work demanding real-time PCR would be a practical alternative to the gel-based PCR.

In addition, the combination of an automated DNA extraction and the closed system of the real-time PCR provides a faster and less work-intensive method with a minimized risk of contamination compared to the gel-based PCR. Furthermore, the real-time PCR method includes the dUTP-uracil- $N$-glyco- sylase system, minimizing the risk of carryover contamination. The PCR reagents used in the method can be mixed in advance, distributed in smaller quantities, and frozen at $-20^{\circ} \mathrm{C}$ for up to 6 months and be ready to use. These features are a major benefit for on-site use of the test. The method is an open-formula technique, i.e., the reagents and target gene, etc., are known, in contrast to commercial kits.

In conclusion, the real-time PCR method complied with the criteria for the validation of alternative microbiological methods and has been approved by NordVal as an alternative method for detection of thermotolerant Campylobacter spp. in chicken samples. The method is currently implemented for use in separated-slaughtering practice by the leading poultry producers in Denmark as part of a risk management program, and for the certified production of Campylobacter-free chicken.

\section{ACKNOWLEDGMENTS}

This work was supported in part by the Danish Directorate for Food, Fisheries, and Agri-Business (DFFE) (grant no. 3401-66-03-5); in part by the CampyFood project of the Nordic Innovation Centre (grant no. F040301); in part by the Nordic Council of Ministers (grant no. 681048-05317); and in part by the European Union through the FoodPCR 2 research project as part of the Network of Excellence MEDVET-NET (FOOD-CT-2004-506122) under the 6th RTD Framework.

We thank Mette Skafte Thomsen, Sarah Omø Nielsen, and Stefan Jensen for excellent technical assistance and Danpo Ltd. for providing the sample material.

\section{REFERENCES}

1. Anonymous. 1990. Campylobacter jejuni/coli. Detection in foods, 2nd ed. Publication no. 119. Nordic Committee on Food Analysis, Esbo, Finland.

2. Anonymous. 2001. The increasing incidence of human campylobacteriosis. Report and proceedings of a WHO consultation of experts, Copenhagen, Denmark, 21 to 25 November 2000, p. 73-76. WHO document WHO/CDS/ CSR/APH 2001.7. WHO, Geneva, Switzerland.

3. Anonymous. 2002. Microbiology of food and animal feeding stuffs-horizontal method for the detection and enumeration of Campylobacter growing at $41.5^{\circ} \mathrm{C}$. Part 1. Detection method. ISO/TC 34/SC $9 \mathrm{~N} \mathrm{553,} \mathrm{revision} 2$. Result of voting on ISO/CD 10272-1. International Organization for Standardization, Geneva, Switzerland

4. Reference deleted.

5. Anonymous. 2004. NordVal. Protocol for the validation of alternative microbiological methods. Danish Institute for Food and Veterinary Research, Søborg, Denmark. [Online.] http://www.nmkl.org/NordVal/NordVal.htm.

6. Anonymous. 2004. Danish Zoonosis Centre annual report, 2003. Danish Zoonosis Centre, Copenhagen, Denmark. [Online.] http://www.dfvf.dk/files/filer /zoonosecentret/publikationer/annual\%20report/annual_report_2003-endelig.pdf.

7. Baylis, C. L., S. MacPhee, K. W. Martin, T. J. Humphrey, and R. P. Betts. 2000. Comparison of three enrichment media for the isolation of Campylobacter spp. from foods. J. Appl. Microbiol. 89:884-891.

8. Borck, B., H. Stryhn, A. K. Ersbøll, and K. Pedersen. 2002. Thermophilic Campylobacter spp. in turkey samples: evaluation of two automated enzyme immunoassays and conventional microbiological techniques. J. Appl. Microbiol. 92:574-582.

9. Freidman, C. R., J. Neimann, H. C. Wegener, and R. V. Tauxe. 2000. Epidemiology of Campylobacter jejuni infections in the United States and other industrialized nations, p. 121-138. In I. Nachamkin, M. J. Blaser, and L. S. Tompkins (ed.), Campylobacter, 2nd ed. ASM Press, Washington, D.C.

10. Hoorfar, J., and N. Cook. 2003. Critical aspects of standardisation. In K. Sachse and J. Frey (ed.), Methods in molecular biology, vol. 216. PCR detection of microbial pathogens: methods and protocols. Humana Press, Totowa, N.J.

11. Reference deleted.

12. Josefsen, M. H., N. R. Jacobsen, and J. Hoorfar. 2004. Enrichment followed by quantitative PCR both for rapid detection and as a tool for quantitative risk assessment of food-borne thermotolerant campylobacters. Appl. Environ. Microbiol. 70:3588-3592.

13. Josefsen, M. H., P. S. Lübeck, F. Hansen, and J. Hoorfar. 2004. Towards an international standard for PCR-based detection of foodborne thermotolerant campylobacters: interaction of enrichment media and pre PCR-treatment on carcass rinse samples. J. Microbiol. Methods 58:39-48.

14. Lehmann, E. L. 1975 . Nonparametrics: statistical methods based on ranks. Holden-Day, San Francisco, Calif. 
15. Lübeck, P. S., N. Cook, M. Wagner, P. Fach, and J. Hoorfar. 2003. Towards an international standard for PCR-based detection of food-borne thermotolerant campylobacters: validation in a multicenter collaborative trial. Appl. Environ. Microbiol. 69:5670-5672.

16. Lübeck, P. S., P. Wolffs, S. L. W. On, P. Ahrens, P. Rådström, and J Hoorfar. 2003. Towards an international standard for PCR-based detection of food-borne thermotolerant campylobacters: assay development and analytical validation. Appl. Environ Microbiol. 69:5664-5669.

17. Lund, M., S. Nordentoft, K. Pedersen, and M. Madsen. 2004. Detection of Campylobacter spp. in chicken fecal samples by real-time PCR. J. Clin. Microbiol. 42:5125-5132.

18. Martin, K. W., K. L. Mattick, M. Harrison, and T. J. Humphrey. 2002 Evaluation of selective media for Campylobacter isolation when cycloheximide is replaced with amphotericin B. Lett. Appl. Microbiol. 34:124-129.

19. Neimann, J., J. Engberg, K. Molbak, and H. C. Wegener. 2003. A casecontrol study of risk factors for sporadic Campylobacter infections in Denmark. Epidemiol. Infect. 130:353-366.
20. Pebody, R. G., M. J. Ryan, and P. G. Wall. 1997. Outbreak of Campylobacter infection: rare events for a common pathogen. Commun. Dis. Rep. CDR Rev. 7:R33-R37.

21. Perelle, S., M. Josefsen, J. Hoorfar, F. Dilasser, J. Grout, and P. Fach. 2004 A LightCycler real-time PCR hybridization probe assay for detecting foodborne thermophilic Campylobacter. Mol. Cell Probes 18:321-327.

22. Rudi, K., H. K. Høidal, T. Katla, B. K. Johansen, J. Nordal, and K. S. Jakobsen. 2004. Direct real-time PCR quantification of Campylobacter jejuni in chicken fecal and cecal samples by integrated cell concentration and DNA purification. Appl. Environ. Microbiol. 70:790-797.

23. Sails, A. D., A. J. Fox, F. J. Bolton, D. R. A. Wareing, and D. L. A. Greenway 2004. A real-time PCR assay for the detection of Campylobacter jejuni in foods after enrichment culture. Appl. Environ. Microbiol. 69:1383-1390.

24. Yang, C., Y. Jiang, K. Huang, C. Zhu, and Y. Yin. 2003. Application of real-time PCR for quantitative detection of Campylobacter jejuni in milk and environmental water. FEMS Immunol. Med. Microbiol. 38:265-271. 
Optimization of a 12-hour TaqMan PCR-based method for detection of Salmonella bacteria in meat. Josefsen, M.H., M. Krause, F. Hansen, and J. Hoorfar.

Applied and Environmental Microbiology (2007) 73:3040-3048. 


\title{
Optimization of a 12-Hour TaqMan PCR-Based Method for Detection of Salmonella Bacteria in Meat $\dagger^{\nabla}$
}

\author{
M. H. Josefsen, ${ }^{1}$ M. Krause, ${ }^{1}$ F. Hansen, ${ }^{2}$ and J. Hoorfar ${ }^{1 *}$ \\ National Food Institute, Bülowsvej 27, DK-1790 Copenhagen, ${ }^{1}$ and Danish Meat Research Institute, \\ Maglegårdsvej 2, DK-4000 Roskilde, ${ }^{2}$ Denmark
}

Received 5 December 2006/Accepted 27 February 2007

\begin{abstract}
We developed a 12-h Salmonella detection method, based on $8 \mathrm{~h}$ of preenrichment, followed by automated DNA extraction and a sensitive real-time PCR. The method was optimized to obtain the highest possible yield of cells and DNA. The growth of different Salmonella strains in various preenrichment media and the effects of adding growth-promoting and selective reagents were explored, taking into account their PCR compatibility. The effects of (i) analyzing larger volumes $(1$ to $5 \mathrm{ml})$ from preenriched samples and introducing wash steps prior to DNA extraction, (ii) regulating the amount of paramagnetic particles (increasing it from 60 to $90 \mu \mathrm{l}$ ) in the DNA extraction, (iii) eluting the DNA in reduced volumes (25 or $50 \mu \mathrm{l}$ rather than $100 \mu \mathrm{l}$ ), and (iv) increasing the PCR template volume (from 5 to $20 \mu \mathrm{l}$ ) were investigated. After $8 \mathrm{~h}$ of preenrichment, buffered peptone water yielded the highest number of salmonellae. When analyzing minced meat samples, positive effects of increasing the initial sampling volume from 1 to $5 \mathrm{ml}$ and increasing the amount of paramagnetic particles to $90 \mu \mathrm{l}$ were observed. However, washing the pellet and eluting the DNA in reduced volumes (25 and $50 \mu \mathrm{l}) \mathrm{had}$ no positive effects and resulted in decreased reproducibility. Increasing the amount of PCR template DNA from 5 to $20 \mu \mathrm{l}$ improved the threshold cycle value by approximately 2 . The improved 12-h PCR method was successfully compared to a reference culture method with 100 minced meat and poultry samples, with a relative accuracy of $99 \%$, a relative sensitivity of $98 \%$, and a relative specificity of $100 \%$.
\end{abstract}

Bacteriological detection of Salmonella in foods and environmental samples is costly, laborious, and time-consuming, requiring up to 5 days to obtain a confirmed result. Thus, rapid and cost-effective detection of Salmonella is of major interest to the food industry and the public. Real-time PCR technology offers several advantages compared to classical bacteriology in terms of speed, detection limit, potential for automation, and cost $(17,24)$. However, it is essential that new PCR methods be reliable and robust. They have to comply with legislation on microbiological criteria for foodstuffs and be able to detect as few as one Salmonella bacterium per $25-\mathrm{g}$ sample. They should be validated against reference culture methods, and last, but not least, they should be sufficiently robust to be transferred from the expert laboratory to end users.

Several PCR-based methods for the detection of Salmonella in foodstuff have been published. Most of these methods operate with preenrichment periods of 16 to $24 \mathrm{~h}$, followed by DNA purification and gel-based or real-time PCR $(8,11,13$, $16,18,34)$. Only a few of them report reduced preenrichment times of 6 to $12 \mathrm{~h}(1,12,27)$. Both Ellingson et al. (12) and Agarwal et al. (1) reported a preenrichment period of only $6 \mathrm{~h}$ for the detection of Salmonella by PCR. In a study by Ellingson et al. (12), the results obtained by real-time PCR correlated $100 \%$ with a reference culture method. However, for both studies, the samples analyzed were inoculated with at least 1 $\mathrm{CFU} / \mathrm{g}$ (not per $25 \mathrm{~g}$ ) food sample; thus, it is questionable if

\footnotetext{
* Corresponding author. Mailing address: National Food Institute, Bülowsvej 27, DK-1790 Copenhagen, Denmark. Phone: 45-72346251. Fax: 45-72346001. E-mail: jho@dfvf.dk.

$\dagger$ Supplemental material for this article may be found at http://aem .asm.org/.

${ }^{\nabla}$ Published ahead of print on 9 March 2007.
}

these methods can meet the legislative demand of detection of 1 CFU/25-g sample. In a recent study by Myint et al. (27) five Salmonella-positive chicken samples were subjected to PCR after 2 to $18 \mathrm{~h}$ of preenrichment, with a sampling interval of $2 \mathrm{~h}$. Even though two out of the five samples were detectable by PCR after $8 \mathrm{~h}$ of preenrichment, it required $18 \mathrm{~h}$ of preenrichment for all five samples to be detected.

The present study describes the development and optimization of a 12-h Salmonella analysis for the meat industry, enabling a faster release of Salmonella-free fresh meat and meat products. The method is based on a shortened preenrichment period combined with increased detection sensitivity in a realtime PCR.

Because of low levels of Salmonella in meat from subclinically infected herds, a preenrichment step is usually included prior to PCR. The preenrichment was followed by a TaqMan PCR assay including an internal amplification control (IAC) (25). However, the shortened preenrichment period of only $8 \mathrm{~h}$ did not produce Salmonella counts that could be detected consistently by this PCR. For this reason, critical steps throughout the method were optimized in order to obtain the highest possible yield of cells and DNA recovery after automated DNA extraction. In addition, the detection limit of the PCR method was optimized by implementing the locked nucleic acid (LNA) technology (30). LNA probes have a higher melting temperature than TaqMan probes because the LNA modifications provide stronger hybridization between doublestranded DNAs and are reported to be more sensitive (28).

Besides evaluating alternative preenrichment broths, optimization of pre-PCR treatment was attempted by increasing the sampling volume and introducing washing steps prior to DNA extraction. The DNA extraction protocol used in this 
study has been shown to be a promising method for extracting bacterial DNA from other matrices (23). The DNA loss in this method was evaluated, and the method was optimized with regard to the amounts of paramagnetic particles and elution buffer. Finally, the effect of increasing the volume of template DNA was studied.

The improved 12-h PCR method was compared to the reference culture method for Salmonella from the Nordic Committee on Food Analysis (NMKL no. 71; reference 3) with 50 artificially inoculated samples of minced pork meat and 50 artificially inoculated poultry samples.

\section{MATERIALS AND METHODS}

Optimization of growth conditions. In the experiments described below, all of the samples and media were preheated to $37^{\circ} \mathrm{C}$ prior to preenrichment.

The first step was to confirm if shaking during preenrichment had any beneficial effect on the number of salmonellae present after $8 \mathrm{~h}$ (29). Overnight cultures of four of the Salmonella strains most frequently isolated from pork were prepared in buffered peptone water (BPW; Oxoid, Basingstoke, United Kingdom). The number of CFU per milliliter was determined by plating 10 -fold dilution series on blood agar (Statens Serum Institute, Copenhagen, Denmark) in duplicate.

Salmonella enterica serovar Typhimurium CCUG 31939, S. enterica serovar Enteritidis CCUG 32352, S. enterica serovar Dublin, and S. enterica serovar Infantis (in-house collection) were inoculated at a level of 1 to $10 \mathrm{CFU}$ into 100 $\mathrm{ml}$ of BPW in quadruplicate and incubated at $37^{\circ} \mathrm{C}$. Half of the preenrichments were shaken (60 rpm, Certomat U; B. Braun Biotech International, Göttingen, Germany), and half were incubated without shaking. The numbers of salmonellae in the preenrichments were determined by plating on blood agar after 6,8 , and $24 \mathrm{~h}$ of incubation.

The second step was to examine whether alternative nutrient media would be superior to BPW in supporting the growth of Salmonella and if these were PCR compatible, i.e., not inhibiting the PCR. One-hundred-milliliter volumes of brain heart infusion (BHI) broth (Oxoid) and tryptone soya broth (TSB; Becton Dickinson, Franklin Lakes, NJ) were inoculated in duplicate with 1 to $10 \mathrm{CFU}$ of each aforementioned Salmonella strain and incubated at $37^{\circ} \mathrm{C}$. The number of salmonellae in the preenrichments was determined by plating on blood agar after 6,8 , and $24 \mathrm{~h}$ of incubation. To test the PCR inhibition of the media, an overnight culture containing $1.9 \times 10^{9} \mathrm{CFU} / \mathrm{ml}$ was diluted in $\mathrm{BPW}, \mathrm{BHI}$, and TSB to $10^{-5}$ to $10^{-8}$ and the DNA was extracted and analyzed in duplicate in the PCR assay.

Growth-promoting reagents. The third step in the optimization process was to study the effect of adding sodium pyruvate to the preenrichment media (26). One-hundred-milliliter volumes of BPW containing $0,0.2$, and $0.4 \mathrm{~g} /$ liter sodium pyruvate (Sigma) were inoculated in duplicate with 1 to $10 \mathrm{CFU}$ of each Salmonella strain and incubated at $37^{\circ} \mathrm{C}$. The numbers of salmonellae in the BPW were determined by plating on blood agar after 6,8 , and $24 \mathrm{~h}$ of incubation.

The effect of adding egg yolk to the preenrichment media was investigated. $S$ enterica serovar Typhimurium CCUG 31939 and S. enterica serovar Infantis (in-house collection) were inoculated at a level of 1 to $10 \mathrm{CFU}$ into $100 \mathrm{ml} \mathrm{BPW}$ containing $0.5,1.0$, and $5.0 \%$ egg yolk (Oxoid) and incubated at $37^{\circ} \mathrm{C}$. The number of salmonellae in the BPW was determined by plating on blood agar after $8 \mathrm{~h}$ of incubation.

Selective reagents. In order to suppress competitive flora and thereby improve the growth conditions for Salmonella, the effect of adding a range of different selective reagents to the BPW was investigated. To BPW were added novobiocin (20, 50, and $100 \mathrm{mg} /$ liter; Fluka, Buchs, Switzerland), brilliant green (10, 20, and $50 \mathrm{mg} /$ liter; Fluka), malachite green oxalate salt $(50,100$, and $250 \mathrm{mg} / \mathrm{liter}$, Fluka), tergitol 4 (1, 2, and $4 \mathrm{ml} /$ liter; Fluka), sodium deoxycholate $(2.5,5$, and $7.5 \mathrm{~g} /$ liter; Fluka), and finally sulfamandelate supplement (1, 2, and 3 vials/liter; Oxoid). Samples of minced pork meat $(10 \mathrm{~g})$, frozen at $-18^{\circ} \mathrm{C}$ and thawed, were transferred to $90 \mathrm{ml}$ of BPW with the selective reagents added and inoculated with 1 to 10 and 10 to $100 \mathrm{CFU} / \mathrm{g}$ sample by using freeze-stressed $S$. enterica serovar Typhimurium CCUG 31939 and S. enterica serovar Infantis (in-house collection). Stressed cells were prepared from a $\mathrm{BHI}$ culture grown at $37^{\circ} \mathrm{C}$ for 20 to $24 \mathrm{~h}$ and frozen at $-18^{\circ} \mathrm{C}$. Before use, both minced meat samples and freeze-stressed cells were thawed at $4^{\circ} \mathrm{C}$. The samples were incubated at $37^{\circ} \mathrm{C}$ for $20 \mathrm{~h}$. Aliquots for PCR were drawn after 6, 8, and $20 \mathrm{~h}$. DNA extraction was performed prior to analysis by the PCR assay (see below).
Automated DNA extraction. One-, 2-, and 5-ml aliquots were drawn from the preenrichments for DNA extraction. The aliquots were centrifuged at 3,000 $\times g$ for $5 \mathrm{~min}$ at $4^{\circ} \mathrm{C}$, and DNA extraction was performed with a KingFisher (Thermo Labsystems, Helsinki, Finland) and a DNA isolation kit for blood, stool, cells, and tissue (Magnesil KF, Genomic System; Promega) as specified by the manufacturer. Briefly, the sample pellet was resuspended in lysis buffer and transferred to a 96-well plate (Thermo Labsystems) containing paramagnetic particles, washing buffers, and elution buffer. The DNA extraction program consisted of two salt buffer washing steps and two alcohol buffer washing steps, followed by a final elution step (for a detailed protocol, see InnovationsPCR at www.foodpcr .com). Five to $20 \mu \mathrm{l}$ of the extracted DNA was used as the template in the PCR.

TaqMan PCR. A TaqMan real-time PCR method, targeting a region within the trRSBCA locus required for tetrathionate respiration, for the specific detection of Salmonella was set up (adopted from reference 25, with the following modifications). The PCR was performed on an Mx3005P (Stratagene, La Jolla, $\mathrm{CA}$ ) in a total reaction volume of $25 \mu \mathrm{l}$, consisting of $1.5 \mathrm{U}$ of Tth DNA polymerase (Roche Applied Science, Mannheim, Germany), $2.5 \mu \mathrm{l}$ of $10 \times$ PCR buffer for Tth DNA polymerase (Roche Applied Science), $500 \mu \mathrm{M}$ deoxynucleoside triphosphate blend with dUTP (Applied Biosystems, Foster City, CA), 4.0 $\mathrm{mM} \mathrm{MgCl} 2$ (Roche Applied Science), $8 \%$ pure glycerol (Merck, Darmstadt, Germany), $1 \mathrm{~g}$ /liter bovine serum albumin (Roche Applied Science), 2\% dimethyl sulfoxide (Sigma, Steinheim, Germany), $240 \mathrm{nM}$ both LNA target probe (6-FAM [6-carboxyfluorescein]-CG+ACGGCG+AG+ACCG-BHQ1; SigmaProligo, Paris, France) and an IAC probe (JOE-CACACGGCGACGCGAAC GCTTT-BHQ1; MWG Biotech, Ebersberg, Germany), and $5 \mu \mathrm{l}$ of purified DNA. The cycle temperature profile was initial denaturation at $95^{\circ} \mathrm{C}$ for $3 \mathrm{~min}$, followed by 40 cycles of $95^{\circ} \mathrm{C}$ for $30 \mathrm{~s}, 65^{\circ} \mathrm{C}$ for $60 \mathrm{~s}$, and $72^{\circ} \mathrm{C}$ for $30 \mathrm{~s}$. Fluorescence measurements were obtained online and analyzed with the MxProMx3005P software (version 3.00). The threshold was assigned by using the software option background-based threshold; i.e., the standard deviation of all amplifications was determined from cycle 5 to cycle 9 , and this value was multiplied by a background sigma multiplier of 10 . Each PCR run included three positive DNA controls (S. enterica serovar Typhimurium 51K61; Institute for Reference Material and Measurements [IRMM], Geel, Belgium) at final concentrations of $0.5,0.05$, and $0.005 \mathrm{ng} / \mathrm{PCR}$ tube, a nontemplate control (only the master mix and PCR grade water), and a negative DNA control (Escherichia coli O157; IRMM) at a concentration of $5 \mathrm{ng} / \mathrm{PCR}$ tube.

Optimization of sample preparation. The effects of analyzing larger volumes from BPW and introducing washing of the pellet prior to DNA extraction were investigated. A 25 -g sample of minced pork meat was inoculated with 1 to 10 CFU of S. enterica serovar Livingstone (in-house collection), transferred to 225 $\mathrm{ml}$ of $\mathrm{BPW}$, and incubated at $37^{\circ} \mathrm{C}$ for $8 \mathrm{~h}$. One-, 2-, and $5-\mathrm{ml}$ aliquots were drawn (eight replicates). DNA was extracted from half of the replicates directly, and pellets from the remaining replicates were washed before DNA extraction; i.e., twice they were centrifuged at $3,000 \times g$ for $5 \mathrm{~min}$ and the pellet was resuspended in $1 \mathrm{ml}$ of physiological saline. After DNA extraction, replicates were analyzed in the PCR.

Loss of DNA during extraction. The amount of DNA lost in the extraction procedure was evaluated by comparing $C_{T}$ (threshold cycle) values of samples containing a known amount of reference DNA before and after automated DNA extraction. As shown in Table 1, the experiment was designed so that theoretically equivalent amounts of DNA were analyzed in the PCR. Four samples were prepared from reference DNA (S. enterica serovar Typhimurium 51K61; IRMM) and $1 \times$ Tris-EDTA buffer to final concentrations of $0.1,0.05,0.01$, and 0.005 $\mathrm{ng} / \mu \mathrm{l}$. The samples were analyzed in duplicate in the PCR before and after automated DNA extraction.

In the same experimental setup, the effect of regulating the amount of paramagnetic particles was investigated. The DNA was extracted in triplicate from samples containing the aforementioned concentrations of DNA by using 60,75 , and $90 \mu \mathrm{l}$ of paramagnetic particles, respectively. The samples were subsequently analyzed in replicate in the PCR.

Increasing the concentration of DNA. The effect of reducing the volume of elution buffer to increase the DNA concentration was investigated. A 25-g sample of minced pork meat was inoculated with 1 to 10 and 10 to $100 \mathrm{CFU}$ of S. enterica serovar Typhimurium CCUG 31939, transferred to $225 \mathrm{ml}$ of BPW, and incubated at $37^{\circ} \mathrm{C}$ for $8 \mathrm{~h}$. One-milliliter aliquots were drawn (nine replicates from each preenrichment), and the DNA was extracted from the replicates with 100,50 , and $25 \mu \mathrm{l}$ of elution buffer, respectively. The replicates were analyzed in the PCR.

Increasing the PCR template DNA volume. The effect of increasing the PCR template volume was investigated. A $25 \mathrm{~g}$ sample of minced pork meat was inoculated with 1 to 10 or 10 to $100 \mathrm{CFU}$ of $S$. enterica serovar Typhimurium CCUG 31939, transferred to $225 \mathrm{ml}$ of BPW, and incubated at $37^{\circ} \mathrm{C}$ for $8 \mathrm{~h}$. 
TABLE 1. Loss of DNA in the extraction procedure

\begin{tabular}{|c|c|c|c|c|}
\hline \multirow{2}{*}{$\begin{array}{c}\text { Treatment and } \\
\text { DNA concn } \\
(\mathrm{ng} / \mu \mathrm{l}) \text { in PCR } \\
\text { mixture } \\
\end{array}$} & \multirow{2}{*}{$\begin{array}{c}\text { Amt (ng) of } \\
\text { DNA } \\
\text { entering } \\
\text { KingFisher }\end{array}$} & \multirow{2}{*}{$\begin{array}{l}\text { Elution vol }(\mu l) \text {, } \\
\text { KingFisher }\end{array}$} & \multicolumn{2}{|c|}{$C_{T}$ value $^{a}$} \\
\hline & & & $\begin{array}{l}\text { Salmonellal } \\
\text { FAM }\end{array}$ & IAC/HEX \\
\hline \multicolumn{5}{|l|}{ Direct PCR } \\
\hline 0.1 & & & 20.5 & 30.6 \\
\hline 0.1 & & & 20.3 & 31.4 \\
\hline \multicolumn{5}{|l|}{ DNA extraction } \\
\hline $0.1^{b}$ & 8 & 80 & 25.6 & 30.1 \\
\hline $0.1^{b}$ & 8 & 80 & 25.5 & 30.3 \\
\hline \multicolumn{5}{|l|}{ Direct PCR } \\
\hline 0.05 & & & 20.6 & 29.8 \\
\hline 0.05 & & & 20.0 & 30.2 \\
\hline \multicolumn{5}{|l|}{ DNA extraction } \\
\hline $0.05^{b}$ & 4 & 80 & 25.0 & 30.1 \\
\hline $0.05^{b}$ & 4 & 80 & 25.5 & 30.1 \\
\hline \multicolumn{5}{|l|}{ Direct PCR } \\
\hline 0.01 & & & 23.8 & 30.3 \\
\hline 0.01 & & & 23.0 & 31.0 \\
\hline \multicolumn{5}{|l|}{ DNA extraction } \\
\hline $0.01^{b}$ & 0.8 & 80 & 28.7 & 29.8 \\
\hline $0.01^{b}$ & 0.8 & 80 & 27.6 & 29.7 \\
\hline \multicolumn{5}{|l|}{ Direct PCR } \\
\hline 0.005 & & & 22.7 & 30.3 \\
\hline 0.005 & & & 22.3 & 30.4 \\
\hline \multicolumn{5}{|l|}{ DNA extraction } \\
\hline $0.005^{b}$ & 0.4 & 80 & 26.9 & 29.9 \\
\hline $0.005^{b}$ & 0.4 & 80 & 27.0 & 30.2 \\
\hline
\end{tabular}

${ }^{a} C_{T}$ values obtained in PCR from samples with similar DNA concentrations subjected directly to PCR and following DNA extraction.

${ }^{b}$ Estimated DNA concentration if the extraction procedure was $100 \%$ efficient.

One-milliliter aliquots were drawn (three replicates from each preenrichment). DNA was extracted and subsequently analyzed in the PCR with 5 and $10 \mu \mathrm{l}$ of template DNA in a total volume of $25 \mu \mathrm{l}$ of master mix and $20 \mu \mathrm{l}$ of template DNA in a total volume of $50 \mu \mathrm{l}$ of master mix.

Validation against a reference culture method. The final 12-h PCR method was compared to the reference culture method for Salmonella from the Nordic Committee on Food Analysis (NMKL no. 71; reference no. 3) with 100 artificially inoculated minced meat and poultry neck skin samples. As the prevalence of Salmonella-positive pork meat samples is 1 to $2 \%$ and that of Salmonella-positive broiler meat samples is $1.7 \%$ at the moment (5), a statistically valid study would require a very large number of samples. For this reason, the comparison was performed with samples artificially inoculated with Salmonella in the exponential growth phase. This alternative to naturally contaminated samples is in compliance with international guidelines $(6,7)$.

Twenty-five grams of Salmonella-free fresh minced pork meat was transferred to $225 \mathrm{ml}$ of BPW $\left(37^{\circ} \mathrm{C}\right)$. Nine samples were inoculated with 1 to $10 \mathrm{CFU}$ of $S$. enterica serovar Typhimurium, 10 were inoculated with 1 to $10 \mathrm{CFU}$ of $S$. enterica serovar Livingstone, and 14 were inoculated with 10 to $100 \mathrm{CFU}$ of S. enterica serovar Livingstone. The remaining 17 samples were left uninoculated.

Twenty-five grams of poultry neck skin was cut into small pieces and transferred to $225 \mathrm{ml}$ of BPW $\left(37^{\circ} \mathrm{C}\right)$. Fifteen samples were inoculated with 1 to 10 CFU of S. enterica serovar Enteritidis, and 14 were inoculated with 1 to $10 \mathrm{CFU}$ of $S$. enterica serovar Typhimurium. The remaining samples were left uninoculated.

All of the samples were preheated to $37^{\circ} \mathrm{C}$ and homogenized by hand for $20 \mathrm{~s}$. After $8 \mathrm{~h}$ of preenrichment at $37^{\circ} \mathrm{C}, 5-\mathrm{ml}$ aliquots were drawn for DNA extrac- tion with $75 \mu \mathrm{l}$ of paramagnetic beads, followed by a PCR with $10 \mu \mathrm{l}$ of the extracted DNA as the template.

The enrichment was thereafter continued for up to $24 \mathrm{~h}$ according to NMKL no. 71 (3). The next day, $100 \mu \mathrm{l}$ was transferred to $10 \mathrm{ml}$ of Rappaport-Vassiliadis soy peptone (Oxoid) broth preheated to $37^{\circ} \mathrm{C}$. The Rappaport-Vassiliadis soy peptone broth was incubated at $41.5^{\circ} \mathrm{C}$ for $24 \mathrm{~h}$ and inoculated onto the surface of the selective plating media xylose lysine deoxycholate (Oxoid) and Rambach (Merck). The plates were incubated at $37^{\circ} \mathrm{C}$ for $24 \mathrm{~h}$, and presumptive colonies were transferred to 5\% blood agar plates (Statens Serum Institute) and confirmed by API 20E (BioMérieux, Marcy l'Étoile, France) and by serotyping.

Statistical analysis. A paired-sample $t$ test was performed according to Campbell (10) on the data obtained by comparing preenrichments that were shaken and those that were not shaken. The data obtained by comparing the three preenrichment broths (BPW, BHI, and TSB) and adding growth-promoting reagents to the preenrichments were analyzed in a single-factor one-way analysis of variance according to Campbell (10), with an $\alpha$ of 0.05 .

When comparing the improved 12-h PCR method to the reference culture method, the test characteristics relative accuracy (AC), sensitivity, and specificity were evaluated (7). AC is defined as the degree of correspondence between the responses obtained by the PCR method and the reference culture method with identical samples, as follows: $(\mathrm{PA}+\mathrm{NA}) \times 100 /(\mathrm{PA}+\mathrm{NA}+\mathrm{PD}+\mathrm{ND})$, where PA refers to positive agreement, NA is negative agreement, PD is positive deviation, and ND is negative deviation. Sensitivity is defined as the ability of the PCR method to detect the target compared to the reference culture method, as follows: PA $\times 100 /(\mathrm{PA}+\mathrm{FN})$, where FN refers to false negatives. Specificity is defined as the ability of the PCR method not to detect the target when it is not detected by the reference culture method, as follows: $(\mathrm{NA} \times 100) /(\mathrm{NA}+\mathrm{FP})$, where FP refers to false positives.

\section{RESULTS}

Optimization of growth conditions. Shaking the preenrichment culture had no beneficial effect on the growth of any of the Salmonella strains after 6 and $8 \mathrm{~h}$. After $6 \mathrm{~h}$ of incubation, the average number of salmonellae was $9.6 \times 10^{3} \mathrm{CFU} / \mathrm{ml}$ in the samples not shaken and $2.6 \times 10^{3} \mathrm{CFU} / \mathrm{ml}$ in the samples shaken $(P=0.2)$. The average number of salmonellae after $8 \mathrm{~h}$ was $2.3 \times 10^{5} \mathrm{CFU} / \mathrm{ml}$ in the samples not shaken and $9.7 \times 10^{4} \mathrm{CFU} / \mathrm{ml}$ in the samples shaken $(P=0.4)$. However, after incubation for $24 \mathrm{~h}$, shaking increased the number of CFU per milliliter by $1 \log$ unit $(P=0.0003)$, as the average number reached $6.5 \times 10^{9} \mathrm{CFU} / \mathrm{ml}$, compared to $5.8 \times 10^{8}$ $\mathrm{CFU} / \mathrm{ml}$ for those not shaken.

Analysis of the results obtained by BHI, TSB, and BPW showed no significant difference in the abilities of the three different preenrichment media to support growth of Salmonella after 6 and $8 \mathrm{~h}$. After $6 \mathrm{~h}$, the average number of salmonellae reached $9.6 \times 10^{3} \mathrm{CFU} / \mathrm{ml}$ in $\mathrm{BPW}, 1.2 \times 10^{3} \mathrm{CFU} / \mathrm{ml}$ in TSB, and $1.4 \times 10^{3} \mathrm{CFU} / \mathrm{ml}$ in BHI $(P=0.15)$. After $8 \mathrm{~h}$, these values were $2.3 \times 10^{5} \mathrm{CFU} / \mathrm{ml}$ in $\mathrm{BPW}, 6.4 \times 10^{4}$ $\mathrm{CFU} / \mathrm{ml}$ in TSB, and $4.3 \times 10^{4} \mathrm{CFU} / \mathrm{ml}$ in $\mathrm{BHI}(P=0.21)$. After incubation for $24 \mathrm{~h}$, both of the nutrient-rich media, BHI and TSB, resulted in increased growth of Salmonella (BPW, $\sim 5.8 \times 10^{8} \mathrm{CFU} / \mathrm{ml}$; TSB, $\sim 6.1 \times 10^{9} \mathrm{CFU} / \mathrm{ml}$; BHI, $\sim 5.3 \times$ $10^{9} \mathrm{CFU} / \mathrm{ml}$ [averages]; $\left.P=0.005\right)$. These average results were also reflected on the strain level. The PCR results obtained with the different preenrichment media indicated no difference in the inhibition of PCR among the three media. After $8 \mathrm{~h}$, the average $C_{T}$ values obtained were 20 for BPW, 21.5 for TSB, and 21.1 for BHI. After $24 \mathrm{~h}$ of preenrichment, these values were 15.3 for BPW, 16.7 for TSB, and 15.2 for BHI.

No difference in growth was observed for any of the strains tested when sodium pyruvate or egg yolk was added, regardless of the concentration (data not shown).

Addition of tergitol 4 and sulfamandelate to preenrichment 


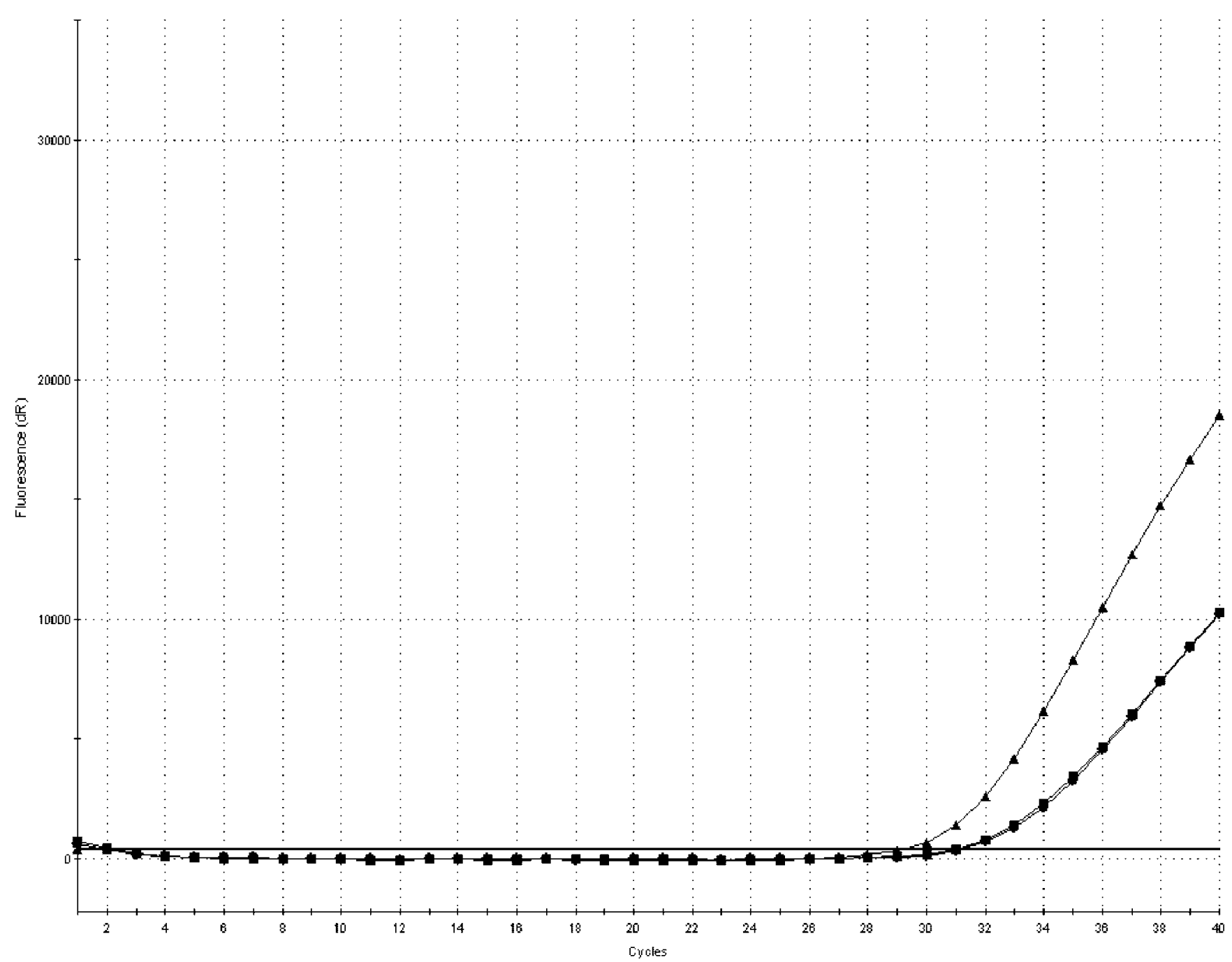

FIG. 1. Amplification plot (FAM) showing the difference in amplification curves obtained by sampling $1 \mathrm{ml}(\mathbf{\bullet}), 2 \mathrm{ml}(\mathbf{\square})$, and $5 \mathrm{ml}(\mathbf{\Delta})$ of minced pork meat inoculated with 1 to $10 \mathrm{CFU}$ of $S$. enterica serovar Livingstone and enriched for $8 \mathrm{~h}$ at $37^{\circ} \mathrm{C}$. Each amplification curve represents an average of four replicates.

of minced pork meat had no effect on the $C_{T}$ values, regardless of the concentrations applied. Malachite green oxalate salt and deoxycholate resulted in slightly higher $C_{T}$ values after $20 \mathrm{~h}$ of preenrichment, while no differences in $C_{T}$ values were observed after 6 and $8 \mathrm{~h}$. Addition of novobiocin $(20$ and $50 \mathrm{mg} /$ liter) and brilliant green (10 mg/liter) had a tendency to improve the PCR results obtained after $8 \mathrm{~h}$ of preenrichment.

Optimization of sample preparation. Increasing the sampling volume of BPW to $5 \mathrm{ml}$ resulted in an improved detection limit and steeper amplification curves, as shown in Fig. 1. The average $C_{T}$ values were 31.8 for a $1-\mathrm{ml}$ volume, 31.6 for a $2-\mathrm{ml}$ volume, and 29.7 for a $5-\mathrm{ml}$ volume. Washing of pellets produced higher $C_{T}$ values and flatter PCR amplification curves. Some samples were not even PCR positive following the two washing steps.

Loss of DNA during extraction. The amount of DNA lost in the extraction procedure when extracting purified DNA resulted in an average increase in $C_{T}$ values of 4.8 (Table 1). The
DNA losses were more pronounced with the higher concentrations of DNA.

Table 2 shows the reverse correlation between the amount of paramagnetic particles and the $C_{T}$ values. The lowest $C_{T}$ values were obtained with $90 \mu \mathrm{l}$ of paramagnetic particles. The effect of increasing the amount of paramagnetic particles was not pronounced, and the $C_{T}$ value was lowered approximately 1 , on average, when using $90 \mu$ l of paramagnetic particles compared to $60 \mu \mathrm{l}$. Steeper amplification curves were, however, obtained with $90 \mu \mathrm{l}$ of paramagnetic particles, as shown in Fig. 2.

Increasing the concentration of DNA. Ambiguous results were obtained when attempting to increase the concentration of DNA by eluting in reduced volumes. Elution of DNA in a $25-\mu l$ volume resulted in very high and nonreproducible $C_{T}$ values. Reducing the elution volume from 100 to $50 \mu \mathrm{l}$ did not improve the results.

Increasing the PCR template DNA. As shown in Fig. 3, increasing the amount of template DNA markedly reduced the 
TABLE 2. $C_{T}$ values obtained in PCR comparing duplicate samples with similar DNA concentrations extracted with 60,75 , or $90 \mu \mathrm{l}$ of paramagnetic particles per sample

\begin{tabular}{|c|c|c|c|c|c|}
\hline \multirow{3}{*}{$\begin{array}{l}\text { DNA concn } \\
(\mathrm{ng} / \mu \mathrm{l}) \\
0.1\end{array}$} & \multirow{3}{*}{$\begin{array}{c}\begin{array}{c}\text { Vol of } \\
\text { paramagnetic } \\
\text { particles } \\
(\mu \mathrm{l} / \text { sample })\end{array} \\
60\end{array}$} & \multicolumn{4}{|c|}{$C_{T}$ value } \\
\hline & & \multicolumn{2}{|c|}{ Salmonella/FAM } & \multicolumn{2}{|c|}{ IAC/HEX } \\
\hline & & 22.1 & 22.2 & 27.0 & 27.0 \\
\hline 0.1 & 60 & 22.2 & 22.3 & 26.9 & 26.8 \\
\hline 0.1 & 60 & 22.7 & 22.8 & 27.1 & 26.6 \\
\hline 0.1 & 75 & 21.8 & 21.9 & 26.9 & 26.8 \\
\hline 0.1 & 75 & 22.7 & 22.5 & 26.6 & 26.5 \\
\hline 0.1 & 75 & 21.9 & 21.9 & 26.9 & 26.6 \\
\hline 0.1 & 90 & 21.9 & 21.6 & 26.9 & 26.7 \\
\hline 0.1 & 90 & 21.8 & 21.9 & 26.6 & 26.3 \\
\hline 0.1 & 90 & 21.8 & 21.8 & 26.5 & 26.4 \\
\hline 0.05 & 60 & 24.5 & 24.6 & 26.6 & 27.1 \\
\hline 0.05 & 60 & 23.8 & 23.7 & 26.8 & 27.1 \\
\hline 0.05 & 60 & 24.1 & 24.3 & 26.5 & 26.9 \\
\hline 0.05 & 75 & 23.6 & 23.5 & 27.3 & 26.6 \\
\hline 0.05 & 75 & 23.1 & 23.1 & 26.7 & 26.9 \\
\hline 0.05 & 75 & 24.5 & 24.4 & 26.8 & 26.5 \\
\hline 0.05 & 90 & 23.9 & 23.9 & 26.7 & 26.8 \\
\hline 0.05 & 90 & 23.3 & 23.4 & 26.8 & 27.2 \\
\hline 0.05 & 90 & 23.2 & 23.4 & 27.2 & 26.5 \\
\hline 0.01 & 60 & 26.9 & 26.9 & 27.1 & 26.8 \\
\hline 0.01 & 60 & 26.7 & 26.3 & 26.4 & 26.6 \\
\hline 0.01 & 60 & 26.9 & 27.6 & 27.0 & 27.4 \\
\hline 0.01 & 75 & 24.8 & 24.9 & 26.8 & 26.7 \\
\hline 0.01 & 75 & 26.3 & 26.8 & 26.8 & 27.2 \\
\hline 0.01 & 75 & 25.0 & 24.9 & 26.8 & 27.0 \\
\hline 0.01 & 90 & 24.8 & 25.2 & 26.5 & 26.7 \\
\hline 0.01 & 90 & 25.7 & 25.7 & 27.1 & 26.5 \\
\hline 0.01 & 90 & 24.7 & 24.9 & 26.9 & 27.2 \\
\hline 0.005 & 60 & 26.7 & 26.6 & 26.7 & 26.7 \\
\hline 0.005 & 60 & 27.2 & 27.4 & 27.0 & 26.8 \\
\hline 0.005 & 60 & 27.3 & 27.3 & 26.9 & 27.1 \\
\hline 0.005 & 75 & 26.6 & 26.6 & 27.0 & 26.5 \\
\hline 0.005 & 75 & 26.0 & 26.3 & 26.7 & 26.8 \\
\hline 0.005 & 75 & 27.8 & 27.6 & 27.1 & 27.2 \\
\hline 0.005 & 90 & 26.2 & 26.2 & 27.4 & 26.8 \\
\hline 0.005 & 90 & 25.8 & 25.6 & 26.9 & 26.8 \\
\hline 0.005 & 90 & 26.3 & 26.3 & 27.0 & 26.8 \\
\hline
\end{tabular}

$C_{T}$ values and resulted in steeper amplification curves. There was a reverse correlation between the amount of template DNA and the $C_{T}$ value, and the lowest $C_{T}$ values were obtained by addition of $20 \mu \mathrm{l}$ of template DNA. Addition of 10 $\mu \mathrm{l}$, compared to $5 \mu \mathrm{l}$, of template DNA also reduced the $C_{T}$ values. The average $C_{T}$ value was reduced from 30.2 for $5 \mu \mathrm{l}$ of template DNA to 29.1 for $10 \mu \mathrm{l}$ of template DNA and to 28.6 for $20 \mu$ l of template DNA for the samples inoculated with 1 to $10 \mathrm{CFU}$ and from 28.6 for $5 \mu \mathrm{l}$ of template DNA to 27.1 for 10 $\mu \mathrm{l}$ of template DNA and to 26.6 for $20 \mu \mathrm{l}$ of template DNA. However, the most significant effect was the steepness and reproducibility of the curves.

Validation against a reference culture method. The reference culture method identified 33 Salmonella-positive and 17 Salmonella-negative minced pork meat samples. For the 12-h PCR method, these values were 32 and 18, respectively. The $C_{T}$ values of the PCR-positive samples inoculated with 1 to 10 CFU were in the range of 23.3 to 37.8 , with an average of 29.6 (Table 3). Samples inoculated with 10 to $100 \mathrm{CFU}$ gave $C_{T}$ values in the range of 21.1 to 26.7 , with an average of 24.6 (Table 3). The relative AC of the PCR method was $98 \%$, its relative sensitivity was $97 \%$, and its relative specificity was $100 \%$.

The reference culture method and the PCR method identified 29 Salmonella-positive and 21 Salmonella-negative poultry samples, resulting in a relative AC, sensitivity, and specificity of $100 \%$. The $C_{T}$ values of the PCR-positive samples were in the range of 23.8 to 33.2 , with an average of 27.7 (Table 3).

For details of the PCR results obtained by addition of selective reagents to BPW or reducing the elution, volume, see the supplemental material.

\section{DISCUSSION}

The 12-h PCR described in the present study is intended as a diagnostic tool for routine use in the meat industry, and therefore a high degree of robustness and reproducibility is imperative. As a tool for ensuring food safety and thereby public health, the method has to be reliable and consistent, day after day, in the hands of different personnel and on different sample matrices. Preliminary studies revealed that the limited preenrichment period of $8 \mathrm{~h}$ in BPW was unable to produce sufficient cell counts to meet these demands; thus, crucial steps of the method were optimized to improve sensitivity and robustness.

The concept of proving the presence or absence of Salmonella with only $8 \mathrm{~h}$ of preenrichment entails the need for optimization of this growth phase to yield the greatest possible amount of cells. The majority of the existing culture methods recommend BPW for resuscitation and preenrichment of Salmonella (2). The findings of the present study gave no reason to alter this. This point was further emphasized by the fact that shaking of the preenrichment cultures, and thereby improving the accessibility of the nutrients, did not increase the number of salmonellae during short-term incubation. This could be due to overgrowth of competitive flora, as found in other studies (33). Fricker (15) found BPW to be superior to lactose broth for preenrichment of Salmonella from sewage sludge. Other studies have shown no significant difference in the diagnostic sensitivity of BPW and universal preenrichment broth in an examination of fecal samples from swine (19). Similar results were found for BPW, TSB, and glucose mineral salt medium used for preenrichment of frozen or fresh samples of minced meat (35).

Adding growth-promoting reagents to BPW did not seem to provide Salmonella with a competitive edge, so as a last resort, addition of selective reagents directly to BPW was attempted. According to reference culture methods, a selective advantage is introduced when transferring preenriched cells to the next enrichment step $(2,4)$. However, because of the time limitations of the present method, this was not possible. In the present study, the experiments with selective reagents were performed with freeze-stressed Salmonella, taking into account the potential presence of damaged cells in the samples. During slaughter of pigs in Denmark, wind chilling is applied, rendering part of the bacterial flora freeze damaged. The lack of a beneficial effect of addition of most of the selective reagents could be due to the restriction of resuscitation and growth of the stressed Salmonella cells caused by the selective pressure in the preenrichment media. Delayed addition of selective reagents could be an alternative way to overcome this problem. 


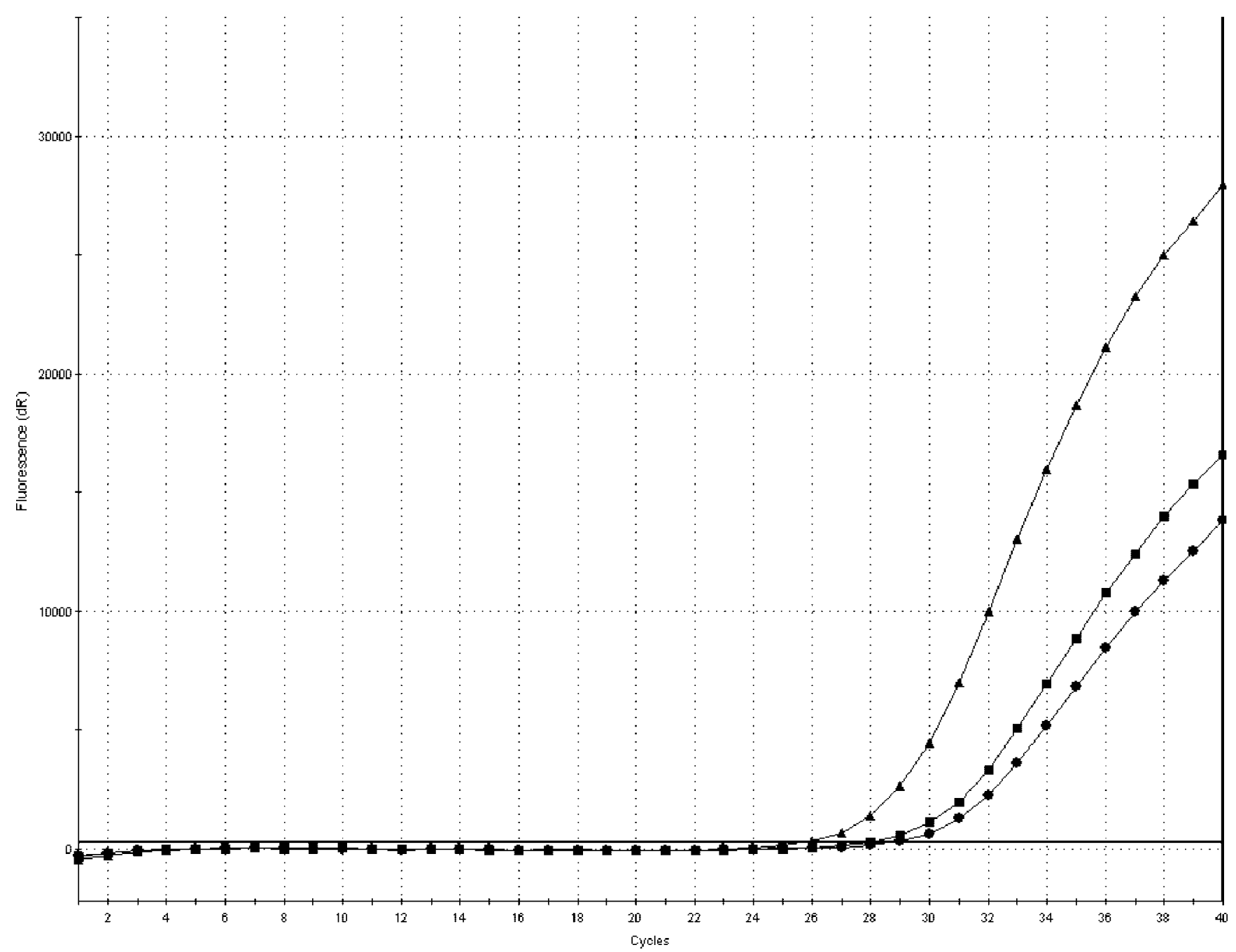

FIG. 2. Amplification plot (FAM) showing the difference in amplification curves obtained from a sample containing $0.01 \mathrm{ng} / \mu 1 \mathrm{DNA}$ extracted with $60(\bullet), 75(\square)$, or $90(\mathbf{\Delta}) \mu$ l of paramagnetic particles, respectively. The amplification curves represent average values of duplicate analyses.

Joosten et al. (21) showed increased recovery of Salmonella in infant formula containing high levels of probiotic microorganisms when malachite green was added to the preenrichment medium at a concentration of $100 \mathrm{mg} / \mathrm{liter}$. However, the recovery rate improved when nonfat dry milk powder was added to the preenrichments to reduce the toxicity of malachite green toward Salmonella, which was also shown previously by van Schothorst and Renaud (36). In a study by Blivet et al. (9), malachite green $(20 \mathrm{mg} /$ liter $)$ and brilliant green $(5 \mathrm{mg} / \mathrm{liter})$ were found to inhibit the growth of various Salmonella strains, while novobiocin (up to $40 \mathrm{mg} /$ liter) enhanced their growth. Novobiocin addition (22 mg/liter) has likewise been reported to increase the recovery of Salmonella from fecal samples (20). Even though addition of novobiocin and brilliant green slightly improved the PCR results obtained after $8 \mathrm{~h}$ in the present study, it was decided not to add them to the BPW. The reference culture method does not include novobiocin or brilliant green, and adding these to the preenrichment would necessitate two preenrichment protocols of parallel samples, thus compromising the validation.
Another subject of importance is the PCR compatibility of the media used. In a study by Stone et al. (32), RappaportVassiliadis and tetrathionate broths were found to be inhibitory to PCR, whereas BHI-as shown in this study-and selenite cystine broth were not. Eyigor et al. (13), on the other hand, found that a PCR performed directly on tetrathionate enrichment broth extracted by boiling was more sensitive than the reference culture method. Knutsson et al. (22) showed that both BPW and BHI inhibited the PCR. They also found that the rTth PCR mixture, with the same DNA polymerase as in the present study, was less influenced by the presence of BPW than the AmpliTaq Gold PCR mixture. In other words, the DNA polymerase type plays a central role.

For the minced meat examined in the present study, a 5-ml volume resulted in markedly improved PCR results compared to a 1-ml volume. A high number of target organisms in a given sample can, however, influence the outcome of a larger sampling volume, and the possibility of overloading the PCR with target DNA should always be considered. Increasing the volume taken from preenrichment will, of course, result in higher 


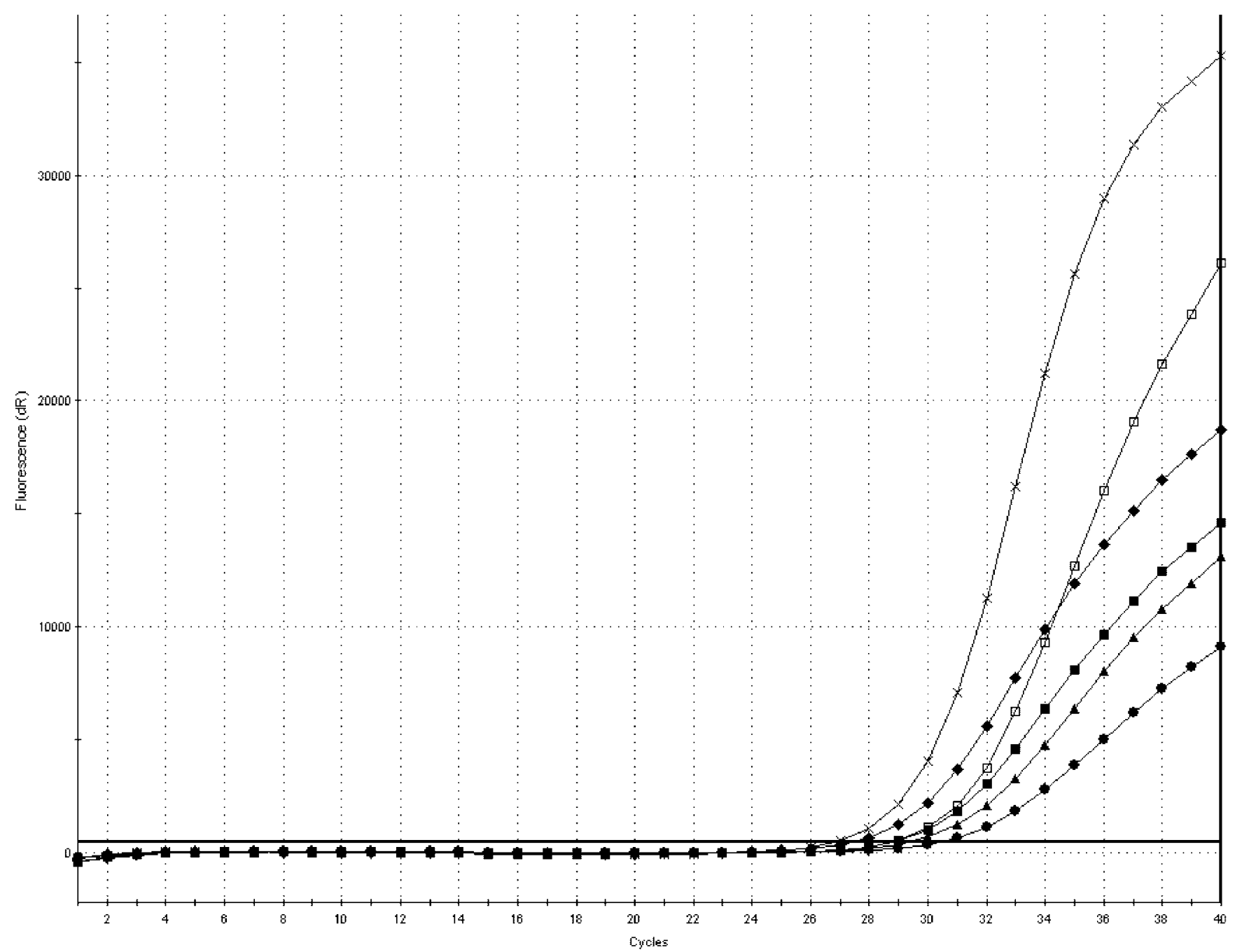

FIG. 3. Amplification plot (FAM) showing the difference in amplification curves obtained by analysis of 5, 10 , and $20 \mu \mathrm{l}$ of template DNA in the PCR from samples of minced pork meat inoculated with 1 to 10 or 10 to 100 CFU of $S$. enterica serovar Typhimurium CCUG 31939 and enriched for $8 \mathrm{~h}$ at $37^{\circ} \mathrm{C}$. The amplification curves represent average values from triplicate analyses. $\bullet, 1$ to $10 \mathrm{CFU}$ and $5 \mu \mathrm{l}$ of template DNA; $\mathbf{\square}, 10$ to $100 \mathrm{CFU}$ and $5 \mu \mathrm{l}$ of template DNA; $\boldsymbol{\Delta}, 1$ to $10 \mathrm{CFU}$ and $10 \mu \mathrm{l}$ of template DNA; $\boldsymbol{\nabla}, 10$ to $100 \mathrm{CFU}$ and $10 \mu \mathrm{l}$ of template DNA; $\square$, 1 to $10 \mathrm{CFU}$ and $20 \mu \mathrm{l}$ of template DNA; $\times, 10$ to $100 \mathrm{CFU}$ and $20 \mu \mathrm{l}$ of template DNA.

numbers of target cells but, inconveniently, also increase the amount of other bacteria and PCR inhibitors. Accordingly, it is essential to find a balance where the advantage of the larger volume is not obscured by more inhibitors.

The automated DNA extraction procedure applied in this study was selected because the 12-h PCR method was developed for use in a routine laboratory with a high throughput and the need for a high degree of quality control. However, the DNA loss during extraction was shown to be high, as an average of $4.8 C_{T}$ units was lost by running pure DNA through the magnetic DNA extraction system. As a rule of thumb, $3.3 C_{T}$ units corresponds to $1 \log$ unit. For example, for viral DNA in various clinical samples, Schuurman et al. (31) showed a DNA recovery of approximately 50\% from magnetic DNA extraction. Ferreira-Gonzalez et al. (14) showed close to $100 \%$ recovery of viral DNA from plasma with a silicone-based kit. Previous in-house comparisons have shown automated DNA extraction with a KingFisher to be similar to, or better than, various manual and kit-based extraction methods (data not shown).

Increasing the amount of initial DNA in a PCR may result in rapid accumulation of high numbers of PCR products and in lower $C_{T}$ values. However, when setting up a routine PCR test, the financial aspect should also be considered. Running a PCR with $20 \mu \mathrm{l}$ of template DNA in a total volume of 50 $\mu l$ of master mix would double the cost of PCR analysis compared to using $10 \mu \mathrm{l}$ of template DNA in a total of $25 \mu \mathrm{l}$ of master mix.

In conclusion, it was successfully demonstrated that the optimized 12-h PCR method for Salmonella detection produced results comparable to those of the reference culture method with artificially inoculated pork meat and poultry samples. Further studies with naturally contaminated samples are needed. The main advantage of the method developed is the reduced time of analysis, enabling faster release of Salmonellafree fresh meat. Moreover, the sample price and workload are 
TABLE 3. Results obtained by analyzing artificially inoculated minced pork meat and poultry samples for the presence of Salmonella by the PCR method ${ }^{a}$

\begin{tabular}{|c|c|c|c|}
\hline \multirow{2}{*}{ Sample } & \multirow{2}{*}{$\begin{array}{l}\text { No. of CFU } \\
\text { inoculated } \\
(\text { organism) }\end{array}$} & \multicolumn{2}{|c|}{$\operatorname{PCR}\left(C_{T}\right.$ value $)$} \\
\hline & & $\mathrm{FAM}^{c}$ & $\mathrm{HEX}^{d}$ \\
\hline \multicolumn{4}{|c|}{ Minced pork meat } \\
\hline 1 & $1-10$ (st) & 28.7 & 33.3 \\
\hline 2 & $1-10$ (st) & 37.7 & 32.9 \\
\hline 3 & $1-10$ (st) & $\mathrm{NA}^{e}$ & 32.6 \\
\hline 4 & $1-10$ (st) & 36.4 & 32.4 \\
\hline 5 & $1-10$ (st) & 33.7 & 32.1 \\
\hline 6 & $1-10$ (st) & 33.6 & 32.3 \\
\hline 7 & $1-10$ (st) & 37.8 & 32.4 \\
\hline 8 & $1-10$ (st) & 33.7 & 32.5 \\
\hline 9 & $1-10(\mathrm{st})$ & 35.2 & 32.1 \\
\hline 10 & $1-10(\mathrm{sl})$ & 24.8 & 34.9 \\
\hline 11 & $1-10(\mathrm{sl})$ & 23.7 & 34.8 \\
\hline 12 & $1-10(\mathrm{sl})$ & 23.3 & 34.5 \\
\hline 13 & $1-10(\mathrm{sl})$ & 25.5 & 33.5 \\
\hline 14 & $1-10(\mathrm{sl})$ & 25.8 & 25.7 \\
\hline 15 & $1-10(\mathrm{sl})$ & 24.5 & 34.1 \\
\hline 16 & $1-10(\mathrm{sl})$ & 27.1 & 34.7 \\
\hline 17 & $1-10(\mathrm{sl})$ & 29.9 & 33.9 \\
\hline 18 & $1-10(\mathrm{sl})$ & 27.2 & 34.6 \\
\hline 19 & 1-10 (sl) & 24.7 & 34.9 \\
\hline 20 & $10-100(\mathrm{sl})$ & 24.0 & 31.4 \\
\hline 21 & $10-100(\mathrm{sl})$ & 24.2 & 32.1 \\
\hline 22 & $10-100(\mathrm{sl})$ & 21.1 & 32.6 \\
\hline 23 & $10-100(\mathrm{sl})$ & 23.6 & 31.5 \\
\hline 24 & $10-100(\mathrm{sl})$ & 23.9 & 31.0 \\
\hline 25 & $10-100(\mathrm{sl})$ & 25.6 & 31.2 \\
\hline 26 & $10-100(\mathrm{sl})$ & 24.2 & 31.1 \\
\hline 27 & $10-100(\mathrm{sl})$ & 25.1 & 31.5 \\
\hline 28 & $10-100(\mathrm{sl})$ & 26.6 & 31.6 \\
\hline 29 & $10-100(\mathrm{sl})$ & 22.1 & 32.0 \\
\hline 30 & $10-100(\mathrm{sl})$ & 26.2 & 31.8 \\
\hline 31 & $10-100(\mathrm{sl})$ & 25.5 & 31.3 \\
\hline 32 & $10-100(\mathrm{sl})$ & 26.7 & NA \\
\hline 33 & $10-100(\mathrm{sl})$ & 24.9 & 32.5 \\
\hline \multicolumn{4}{|l|}{ Poultry skin } \\
\hline 34 & $1-10(\mathrm{se})$ & 28.0 & 28.2 \\
\hline 35 & $1-10(\mathrm{se})$ & 29.2 & 28.7 \\
\hline 36 & $1-10$ (se) & 31.5 & 27.3 \\
\hline 37 & $1-10(\mathrm{se})$ & 29.6 & 27.6 \\
\hline 38 & $1-10$ (se) & 33.2 & 27.5 \\
\hline 39 & $1-10$ (se) & 28.4 & 28.0 \\
\hline 40 & $1-10(\mathrm{se})$ & 30.6 & 27.2 \\
\hline 41 & $1-10(\mathrm{se})$ & 29.0 & 28.5 \\
\hline 42 & $1-10(\mathrm{se})$ & 29.3 & 28.4 \\
\hline 43 & $1-10(\mathrm{se})$ & 29.4 & 28.9 \\
\hline 44 & $1-10(\mathrm{se})$ & 28.3 & 28.1 \\
\hline 45 & $1-10$ (se) & 29.7 & 28.6 \\
\hline 46 & $1-10$ (se) & 28.2 & 27.3 \\
\hline 47 & $1-10(\mathrm{se})$ & 28.8 & 28.1 \\
\hline 48 & $1-10(\mathrm{se})$ & 29.8 & 27.5 \\
\hline 49 & $1-10$ (st) & 24.8 & 27.3 \\
\hline 50 & $1-10$ (st) & 26.7 & 27.5 \\
\hline 51 & $1-10$ (st) & 26.9 & 27.7 \\
\hline 52 & $1-10(\mathrm{st})$ & 26.3 & 27.4 \\
\hline 53 & $1-10$ (st) & 27.5 & 28.2 \\
\hline 54 & $1-10$ (st) & 25.2 & 27.3 \\
\hline 55 & $1-10$ (st) & 26.6 & 28.3 \\
\hline 56 & $1-10$ (st) & 25.1 & 27.4 \\
\hline 57 & $1-10$ (st) & 24.9 & 27.5 \\
\hline 58 & $1-10$ (st) & 25.5 & 27.3 \\
\hline 59 & $1-10$ (st) & 25.6 & 27.7 \\
\hline 60 & $1-10(\mathrm{st})$ & 26.9 & 25.8 \\
\hline 61 & $1-10$ (st) & 23.8 & 25.9 \\
\hline 62 & $1-10(\mathrm{st})$ & 25.7 & 25.9 \\
\hline
\end{tabular}

${ }^{a}$ All samples were found positive by the reference culture method.

${ }^{b}$ st, $S$. enterica serovar Typhimurium; sl, $S$. enterica serovar Livingstone; se, $S$. enterica serovar Enteritidis.

${ }^{c}$ Salmonella target.

${ }^{d}$ Internal amplification control.

${ }^{e}$ NA, no amplification. markedly reduced compared to those of the reference culture method.

The strategies described in the present study are, in most cases, not unique to the detection of Salmonella but could be used to improve the sensitivity and/or shorten the preenrichment time of other real-time PCR-based methods.

\section{ACKNOWLEDGMENTS}

This work was supported in part by Danish Directorate for Food, Fisheries and Agri-Business (DFFE) grant 3414-04-01032, in part by grant F040301 from the CampyFood project of the Nordic Innovation Centre (NICE), and in part by the European Union project BIOTRACER (FOOD-2006-CT-036272).

We thank Kirsten Michaelis and Julia Christensen for excellent technical assistance.

\section{REFERENCES}

1. Agarwal, A., A. Makker, and S. K. Goel. 2002. Application of the PCR technique for a rapid, specific and sensitive detection of Salmonella spp. in foods. Mol. Cell. Probes 16:243-250.

2. Anonymous. 1997. Food-borne pathogens. Monograph number 1, Salmonella. Oxoid Limited, Hampshire, England.

3. Anonymous. 1999. Salmonella. Detection in foods, 5th ed. NMKL no. 71. Nordic Committee on Food Analysis, Esbo, Finland.

4. Anonymous. 2002. Microbiology of food and animal feeding stuffs-horizontal method for the detection of Salmonella spp. ISO 6579, 4th edition. International Organization for Standardization, Geneva, Switzerland.

5. Anonymous. 2004. Annual report on zoonosis in Denmark 2003. Ministry of Food, Agriculture, and Fisheries, Copenhagen, Denmark.

6. Anonymous. 2004. Microbiology of food and animal feeding stuffs-protocol for the validation of alternative methods, ISO 16140, 1st ed. International Organization for Standardization, Geneva, Switzerland.

7. Anonymous. 2005. Protocol for the validation of alternative microbiological methods. NordVal-doc-2005-01-01. Danish Institute for Food and Veterinary Research, Søborg, Denmark.

8. Bennett, A. R., D. Greenwood, C. Tennant, J. G. Banks, and R. P. Betts. 1998. Rapid and definitive detection of Salmonella in foods by PCR. Lett. Appl. Microbiol. 26:437-441.

9. Blivet, D., G. Salvat, F. Humbert, and P. Colin. 1998. Development of a new culture medium for the rapid detection of Salmonella by indirect conductance measurements. J. Appl. Microbiol. 84:399-403.

10. Campbell, R. C. 1989. Statistics for biologists, 3rd ed. Cambridge University Press, Cambridge, Great Britain.

11. Chen, S., A. Yee, M. Griffiths, C. Larkin, C. T. Yamashiro, R. Behari, C. Paszko-Kolva, K. Rahn, and S. A. De Grandis. 1997. The evaluation of a fluorogenic polymerase chain reaction assay for the detection of Salmonella species in food commodities. Int. J. Food Microbiol. 35:239-250.

12. Ellingson, J. L. E., J. L. Anderson, S. A. Carlson, and V. K. Sharma. 2004. Twelve hour real-time PCR technique for the sensitive and specific detection of Salmonella in raw and ready-to-eat meat products. Mol. Cell. Probes 18:51-57.

13. Eyigor A., K. T. Carli, and C. B. Unal. 2002. Implementation of real-time PCR to tetrathionate broth enrichment step of Salmonella detection in poultry. Lett. Appl. Microbiol. 34:37-41.

14. Ferreira-Gonzalez, A., S. Yanovich, M. R. Langley, L. A. Weymouth, D. S. Wilkinson, and C. T. Garrett. 2000. Enhanced analytical sensitivity of a quantitative PCR for CMV using a modified nucleic-acid extraction procedure. J. Clin. Lab. Anal. 14:32-37.

15. Fricker C. R. 1984. A comparison of two methods for the isolation of salmonellae from sewage sludge. Zentbl. Bakteriol. Mikrobiol. Hyg. B 179: $170-178$.

16. Gadó, I., P. Major, M. Kiraly, and M. G. Plaveczky. 2000. Rapid combined assay for Salmonella detection in food samples. Acta Microbiol. Immunol. Hung. 47:445-456.

17. Hanai, K., M. Satake, and T. J. White. 1997. Comparison of commercially available kits for detection of Salmonella strains in foods. Appl. Environ. Microbiol. 63:775-778.

18. Hein, I., G. Flekna, M. Krassnig, and M. Wagner. 2006. Real-time PCR for the detection of Salmonella spp. in food: an alternative approach to a conventional PCR system suggested by the FOOD-PCR project. J. Microbiol. Methods 66:538-547.

19. Hoorfar, J, and A. V. Mortensen. 2000. Improved culture methods for isolation of Salmonella organisms from swine feces. Am. J. Vet. Res. 61:14261429.

20. Jensen, A. N., G. Sørensen, D. L. Baggesen, R. Bødker, and J. Hoorfar. 2003. Addition of novobiocin in preenrichment step can improve Salmonella culture protocol of modified semisolid Rappaport-Vassiliadis. J. Microbiol. Methods 55:249-255. 
21. Joosten, H., E. Bidlas, and N. Garofalo. 2006. Salmonella detection in probiotic products. Int. J. Food Microbiol. 110:104-107.

22. Knutsson, R., C. Löfström, H. Grage, J. Hoorfar, and P. Rådström. 2002 Modeling of $5^{\prime}$ nuclease real-time responses for optimization of a highthroughput enrichment PCR procedure for Salmonella enterica. J. Clin. Microbiol. 40:52-60.

23. Krause, M., M. H. Josefsen, M. Lund, N. R. Jacobsen, L. Brorsen, M. Moos, A. Stockmarr, and J. Hoorfar. 2006. Comparative, collaborative and on-site validation of a TaqMan PCR method as a tool for certified production of fresh, Campylobacter-free chickens. Appl. Environ. Microbiol. 72:5463-5468.

24. Lübeck, P. S., and J. Hoorfar. 2003. PCR technology and applications to zoonotic food-borne pathogens. Methods Mol. Biol. 216:65-84.

25. Malorny, B., E. Paccasonni, P. Fach, C. Bunge, A. Martin, and R. Helmuth. 2004. Diagnostic real-time PCR for detection of Salmonella in food. Appl. Environ. Microbiol. 70:7046-7052.

26. Martin, A., and S. E. Katz. 1991. A resuscitation/selection system for rapid determination of Salmonella in foods. J. Assoc. Off. Anal. Chem. 74:522525 .

27. Myint, M. S., Y. J. Johnson, N. L. Tablante, and R. A. Heckert. 2006. The effect of preenrichment protocol on the sensitivity and specificity of PCR for detection of naturally contaminated Salmonella in raw poultry compared to conventional culture. Food Microbiol. 23:599-604.

28. Proudnikov, D., V. Yuferov, Y. Zhou, K. S. LaForge, A. Ho, and M. J. Kreek 2003. Optimizing primer-probe design for fluorescent PCR. J. Neurosci. Methods 123:31-45.

29. Reissbrodt, R., E. Vielitz, E. Kormann, W. Rabsch, and H. Kuhn. 1996.
Ferrioxamine E-supplemented preenrichment and enrichment media improve various isolation methods for Salmonella. Int. J. Food Microbiol. 29:81-91.

30. Reynisson, E., M. H. Josefsen, M. Krause, and J. Hoorfar. 2006. Evaluation of probe chemistries and platforms to improve the detection limit of realtime PCR. J. Microbiol. Methods 66:206-216.

31. Schuurman, T., A. van Breda, R. de Boer, M. Kooistra-Smid, M. Beld, P. Savelkoul, and R. Boom. 2005. Reduced PCR sensitivity due to impaired DNA recovery with the MagNA Pure LC total nucleic acid isolation kit. J. Clin. Microbiol. 43:4616-4622.

32. Stone, G. G., R. D. Oberst, M. P. Hays, S. McVey, and M. M. Chengappa. 1994. Detection of Salmonella serovars from clinical samples by enrichment broth cultivation-PCR procedure. J. Clin. Microbiol. 32:1742-1749.

33. Thomason, B. M., D. J. Dodd, and W. B. Cherry. 1977. Increased recovery of salmonellae from environmental samples enriched with buffered peptone water. Appl. Environ. Microbiol. 34:270-273.

34. Uyttendaele, M., K. Vanwildemeersch, and J. Debevere. 2003. Evaluation of real-time PCR versus automated ELISA and a conventional culture method using a semi-solid medium for detection of Salmonella. Lett. Appl. Microbiol. 37:386-391.

35. van Schothorst, M., R. J. Gilbert, R. W. Harvey, O. Pietzsch, and E. H. Kampelmacher. 1978. Comparative studies on the isolation of Salmonella from minced meat. Zentbl. Bakteriol. B 167:138-145.

36. van Schothorst, M., and A. M. Renaud. 1985. Malachite green preenrichment medium for improved salmonella isolation from heavily contaminated samples. J. Appl. Bacteriol. 59:223-230. 
Validation of a same-day real-time PCR method for screening of meat and carcass swabs for Salmonella. Löfström, C., M. Krause, M.H. Josefsen, F. Hansen and J. Hoorfar.

BMC Microbiology 9:85 (2009) 


\title{
Validation of a same-day real-time PCR method for screening of meat and carcass swabs for Salmonella
}

\author{
Charlotta Löfström*1, Michael Krause ${ }^{1}$, Mathilde H Josefsen ${ }^{1}$, \\ Flemming Hansen ${ }^{2}$ and Jeffrey Hoorfar ${ }^{1}$
}

\begin{abstract}
Address: ${ }^{1}$ National Food Institute, Technical University of Denmark, Mørkhøj Bygade 19, 2860 Søborg, Denmark and ${ }^{2}$ Danish Meat Research Institute, Maglegårdsvej 2, 4000 Roskilde, Denmark

Email: Charlotta Löfström* - chalo@food.dtu.dk; Michael Krause - mkra@food.dtu.dk; Mathilde H Josefsen - mhjo@food.dtu.dk; Flemming Hansen - fh@danishmeat.dk; Jeffrey Hoorfar - jhoo@food.dtu.dk

* Corresponding author
\end{abstract}

Published: 7 May 2009

BMC Microbiology 2009, 9:85 doi:10.1186/147/-2180-9-85

This article is available from: http://www.biomedcentral.com/147I-2/80/9/85

(c) 2009 Löfström et al; licensee BioMed Central Ltd.

This is an Open Access article distributed under the terms of the Creative Commons Attribution License (http://creativecommons.org/licenses/by/2.0), which permits unrestricted use, distribution, and reproduction in any medium, provided the original work is properly cited.
Received: II February 2009

Accepted: 7 May 2009

\begin{abstract}
Background: One of the major sources of human Salmonella infections is meat. Therefore, efficient and rapid monitoring of Salmonella in the meat production chain is necessary. Validation of alternative methods is needed to prove that the performance is equal to established methods. Very few of the published PCR methods for Salmonella have been validated in collaborative studies. This study describes a validation including comparative and collaborative trials, based on the recommendations from the Nordic organization for validation of alternative microbiological methods (NordVal) of a same-day, non-commercial real-time PCR method for detection of Salmonella in meat and carcass swabs.
\end{abstract}

Results: The comparative trial was performed against a reference method (NMKL-7I:5, 1999) using artificially and naturally contaminated samples $(60$ minced veal and pork meat samples, 60 poultry neck-skins, and 120 pig carcass swabs). The relative accuracy was $99 \%$, relative detection level $100 \%$, relative sensitivity $103 \%$ and relative specificity $100 \%$. The collaborative trial included six laboratories testing minced meat, poultry neck-skins, and carcass swabs as un-inoculated samples and samples artificially contaminated with $1-10 \mathrm{CFU} / 25 \mathrm{~g}$, and 10-100 CFU/25 g. Valid results were obtained from five of the laboratories and used for the statistical analysis. Apart from one of the non-inoculated samples being false positive with PCR for one of the laboratories, no false positive or false negative results were reported. Partly based on results obtained in this study, the method has obtained NordVal approval for analysis of Salmonella in meat and carcass swabs. The PCR method was transferred to a production laboratory and the performance was compared with the BAX Salmonella test on 39 pork samples artificially contaminated with Salmonella. There was no significant difference in the results obtained by the two methods.

Conclusion: The real-time PCR method for detection of Salmonella in meat and carcass swabs was validated in comparative and collaborative trials according to NordVal recommendations. The PCR method was found to perform well. The test is currently being implemented for screening of several hundred thousand samples per year at a number of major Danish slaughterhouses to shorten the post-slaughter storage time and facilitate the swift export of fresh meat. 


\section{Background}

One of the major sources of human Salmonella infection is meat, including pork and poultry $[1,2]$ and therefore efficient and rapid monitoring of Salmonella in the meat production chain is necessary. Traditional bacteriological detection of Salmonella in foods and environmental samples is costly, laborious, and time-consuming, requiring 3-7 days to obtain a confirmed result [3]. Thus, rapid and cost-effective detection of Salmonella is of major interest to the food industry and the public. Real-time PCR technology offers several advantages compared with classical bacteriology in terms of speed, detection limit, potential for automation, and cost [4]. However, it is essential that new PCR methods are reliable, robust and comply with the legislative demand of detecting as few as one Salmonella bacterium per 25-g sample. Furthermore, they should be validated against reference culture methods, and last, but not least, be sufficiently robust to be transferred from the expert laboratory to end users.

There are several real-time PCR methods available for the detection of Salmonella in various kinds of food $[5,6]$ and carcass swabs [7]. Furthermore, a number of commercial real-time PCR systems have been validated for testing of Salmonella in meat and swab samples [5,8-10]. Some of these systems detect Salmonella as fast as 9-10 h in meat samples (iQ Check Salmonella II, Bio-Rad, Hercules, CA and GeneDisc, GeneSystems, Bruz, France), but the total time for analysis of carcass swab samples is $17-20 \mathrm{~h}$. Recently, a non-commercial real-time PCR method for detection of Salmonella in milk powder [11] has been validated in a multicenter trial. However, to our knowledge, there are no reports on multicenter validation trials where non-commercial methods are evaluated for the detection of Salmonella in meat or carcass swabs using real-time PCR.

The objective of this study was to validate a previously developed real-time PCR method $[6,12,13]$ for use as a routine and on-site analysis method for the meat industry. The validation study was performed according to the protocol recommended by the validation body of the Nordic countries (NordVal) $[14,15]$, including comparative and collaborative trials on minced pork and veal meat, chicken neck-skins and pig carcass swab samples. The method is based on a shortened (compared to the NMKL71 method) pre-enrichment in buffered peptone water (BPW) followed by automated DNA purification and subsequent detection using real-time PCR. In this method, a part of the ttrRSBCA locus specific for Salmonella is amplified giving a high selectivity [6]. The PCR method used includes an internal amplification control (IAC), making it useful as a diagnostic tool. The overall time for the analysis of meat samples is $14 \mathrm{~h}$, and for carcass swab samples $16 \mathrm{~h}$. Both time-spans are operational for two-shift work at slaughterhouses. The method has on the basis of results obtained in this study together with already published data on selectivity [6] gained NordVal approval and is currently being implemented at major Danish meat producers.

\section{Results \\ Comparative trial}

The comparative trial was conducted in accordance with the guidelines provided by NordVal [15] and included the matrices meat (minced pork and veal meat as well as poultry neck-skins) and environmental samples (swabs from pig carcasses). The relative detection level, accuracy, sensitivity and specificity were evaluated for the real-time PCR method in comparison with the reference culturebased method currently in use (Table 1)[3].

The detection level of the two methods was 1-10 CFU/25 g sample (corresponding to a relative detection level of $100 \%$ ) in all cases except for the swabs inoculated with $S$. Enteritidis, where it was $10-100 \mathrm{CFU} / 25 \mathrm{~g}$ for the NMKL method (relative detection level > 100\%) (data not

Table I: Results obtained in the comparative trial by the real-time PCR and the reference culture method a, b.

\begin{tabular}{|c|c|c|c|c|c|c|c|c|c|c|}
\hline \multirow[t]{2}{*}{ Sample type } & \multicolumn{6}{|c|}{ No. of samples } & \multicolumn{3}{|c|}{$\%$ Value $^{d}$} & \multirow[t]{2}{*}{$\kappa^{\mathbf{e}}$} \\
\hline & $\mathbf{N}$ & PA & NA & $\mathbf{F N}$ & TP & FP & AC & SE & SP & \\
\hline Minced meat & 60 & 30 & 30 & 0 & 0 & 0 & 100 & 100 & 100 & 1.00 \\
\hline Poultry neck-skins & 60 & 27 & 31 & 0 & 2 & 0 & 97 & 107 & 100 & 0.97 \\
\hline Pig carcass swabs & 120 & 21 & 98 & 1 & 0 & 0 & 99 & 95 & 100 & 0.97 \\
\hline TOTAL & 240 & 78 & 159 & $\mathbf{I}$ & 2 & 0 & 99 & 103 & 100 & 0.97 \\
\hline
\end{tabular}

a PA: Positive Agreement, NA: Negative Agreement, TP: True Positive, FN: False Negative, FP: False Positive, AC: Relative Accuracy, SE: Relative Sensitivity, SP: Relative Specificity, N = PA +NA + FN + TP + FP.

$\mathrm{b}$ Results are given after confirmation.

c Matrices as defined by NordVal [15]; matrix meat: minced meat (raw pork and veal) and poultry neck skins, matrix environmental samples: pig carcass swabs. Meat samples were artificially contaminated and swab samples potentially naturally contaminated.

d See Materials and Methods for accuracy, sensitivity and specificity equations.

e Cohen's kappa calculated according to NMKL procedure no. 20 [26]. 
shown). To determine the relative accuracy, sensitivity and specificity, a total of 240 samples representing meat and environmental samples were analyzed by the PCR and NMKL methods (Table 1). A total of 80 out of 240 samples gave positive results by real-time PCR, compared with a total of 79 by the culture-based method. Two samples showed positive deviation (true positives by the PCR method) and one negative deviation (false negative by the PCR method) (Table 1). A very good agreement between the two methods was obtained using Cohen's kappa (Table 1).

\section{Collaborative trial}

The purpose of the collaborative trial was to determine the variability in the results obtained by the real-time PCR method detecting Salmonella in identical samples. The trial was conducted in accordance with the guidelines provided by NordVal [15]. The samples and the other contents of the ring trial kit sent out to the participants were found to be stable during the period of the trial (data not shown). The influence of the refrigerated transit was investigated prior to the collaborative trial, and no detrimental effects were found after three days (data not shown).

Six laboratories participated in the collaborative trial, and valid results were obtained from five of the laboratories and used for the statistical analysis (Table 2). In agree- ment with the predefined criteria, results from one participant were excluded due to failure in the PCR analysis (lack of amplification in the positive control and several samples with no amplification of either the target or the IAC). The unexpected PCR results obtained by this participant were probably caused by a delay in the transport of the ring trial package ( $>5$ days). Statistical analysis of the results from the remaining five laboratories gave a relative specificity, sensitivity and accuracy of $100 \%$ for all of the tested matrices at all three inoculation levels, except for the relative accuracy for swab samples which was $83 \%$ when all inoculation levels were analyzed together. For the positive control samples containing Salmonella DNA, a $\mathrm{Ct}$ value of $32.6 \pm 1.6$ was obtained for the five laboratories. There were small variations in the $\mathrm{Ct}$ values obtained for duplicate samples of the same matrix at the same spiking level analyzed at each laboratory (standard deviation 0.0-2.7) as well as for the same sample analyzed by each laboratory (standard deviation 1.1-1.9).

\section{External validation}

In order to evaluate the performance of the real-time PCR method on-site, it was transferred and implemented at a production laboratory previously using PCR-based analysis with the BAX system. Artificially contaminated pork filet samples $(n=39)$ were analyzed in parallel with the real-time PCR and BAX methods. In general, a good agreement $(\kappa=0.77)$ was found between the two methods

Table 2: Collaborative trial: PCR results for Salmonella in artificially contaminated meat samples and pig carcass swabs.

\begin{tabular}{|c|c|c|c|c|}
\hline \multirow[t]{2}{*}{ Sample type } & \multirow[t]{2}{*}{ Participant no. } & \multicolumn{3}{|c|}{ Ct values for replicates from indicated level of spiking (CFU/25 g) } \\
\hline & & 0 & $1-10$ & $10-100$ \\
\hline \multirow[t]{6}{*}{ Carcass swabs } & 1 & $>36,>36$ & 17,19 & 19,19 \\
\hline & 2 & $>36,>36$ & 14,16 & 16,16 \\
\hline & 3 & $>36,>36$ & 15,17 & 16,16 \\
\hline & 4 & $>36,>36$ & 16,18 & 17,17 \\
\hline & 5 & $>36,34$ & 16,18 & 19,17 \\
\hline & Mean $\pm S D^{b}$ & n.a.c & $16.5 \pm 1.3$ & $17.1 \pm 1.3$ \\
\hline \multirow[t]{6}{*}{ Poultry neck-skins } & 1 & $>36,>36$ & 28,28 & 25,24 \\
\hline & 2 & $>36,>36$ & 26,26 & 24,24 \\
\hline & 3 & $>36,>36$ & 29,28 & 25,24 \\
\hline & 4 & $>36,>36$ & 24,25 & 23,22 \\
\hline & 5 & $>36,>36$ & 25,25 & 22,23 \\
\hline & Mean $\pm S D^{b}$ & n.a. & $26.6 \pm 1.8$ & $23.6 \pm 1.1$ \\
\hline \multirow[t]{6}{*}{ Minced meat } & I & $>36,>36$ & 20,21 & 17,17 \\
\hline & 2 & $>36,>36$ & 21,20 & 16,18 \\
\hline & 3 & $>36,>36$ & 19,19 & 16,15 \\
\hline & 4 & $>36,>36$ & 18,18 & 13,14 \\
\hline & 5 & $>36,>36$ & 18,18 & 17,13 \\
\hline & Mean $\pm S^{b}$ & n.a. & $19.4 \pm 1.9$ & $15.4 \pm 1.8$ \\
\hline
\end{tabular}

a $\mathrm{Ct}$ values below 36 were considered as positive responses.

$\mathrm{b}$ The mean and standard deviation calculated for all the replicate analysis of the same sample independent of the participant.

c n.a.: not applicable 
based on the results from the 39 artificially contaminated samples (Tables 3 \&4). The real-time PCR method detected 33 of the 39 samples inoculated with Salmonella, whereas the BAX system detected 34 of the 39 samples.

\section{Discussion}

The real-time PCR method validated in the present study is intended as a diagnostic tool for routine use in the meat industry, and therefore has specific demands on speed, ease of automation as well as robustness and reproducibility. Furthermore, the method must be specific for Salmonella and have detection limit comparable with or better than the culture-based methods in use today as official methods. Using the PCR method, the total time for the analysis of Salmonella in meat samples was decreased from at least 3 days for the standard culture-based method [3] to $14 \mathrm{~h}$ for meat samples and $16 \mathrm{~h}$ for swabs. The time for analysis is comparable with the fastest validated DNAbased analysis kit (e.g. from Bio-Rad and GeneSystems) on the market for meat samples and 1-3 h shorter for swab samples. For the meat producer, this means that the meat can be released faster, leading to decreased costs for storage and prolonged shelf life at the retailers. Implementing this method would allow faster release of Salmonella-free fresh meat and meat products.

The sample preparation in the PCR method consists of non-selective enrichment in BPW followed by centrifugation and automated DNA extraction. The use of automated DNA extraction in combination with the closed system of real-time PCR provides a fast and less laborious method with minimized risk of contamination. Furthermore, the real-time PCR method can easily be adapted to include the dUTP-uracil- $N$-glycosylase (UNG) system, minimizing the risk of carryover contamination [16]. The PCR reagents used in the method can be mixed in advance, distributed in smaller, ready-to-use quantities, and frozen at $-20^{\circ} \mathrm{C}$ for up to 3 months [17]. These features are a major benefit for on-site use of the test at the slaughterhouses. The method is an open-formula technique, i.e., the reagents and target gene, etc., are known, in contrast to commercial kits. However, further decreasing the total time for analysis to below $8 \mathrm{~h}$ will certainly be even more beneficial to industry and is a challenge in the further developing of the method.

The prevalence of Salmonella in Danish pork meat and broiler flocks is low $(0.9 \%$ and $2.2 \%$, respectively [18]). Therefore, samples artificially contaminated with Salmonella in the exponential growth phase stressed by a cold storage overnight to simulate the condition under production of poultry and pork meat were used for the majority of the samples included in the validation study. This alternative to naturally contaminated samples is in compliance with international guidelines $[15,19]$. However, naturally contaminated swab samples were used for the comparative trial. The NMKL-71 (1999) method [3] was chosen as the reference method because it is used in the Nordic countries instead of the ISO 6579:2002 method [20]. The difference in the two methods is that in the NMKL method only one selective enrichment media is used Rappaport Vassiliades soy broth (RVS) instead of two in the ISO method (RVS and Muller-Kauffmann Tetrathionate-Novobiocin broth, MKTTn). The methods have been determined to be equal to the respective part of the ISO method [21].

The real-time PCR method amplifies a part of the ttrRSBCA locus used for tetrathionate respiration in Salmonella. The relative selectivity of the PCR assay (primers and probes) has previously been found to be $100 \%$ when tested on 110 Salmonella strains and 87 non-Salmonella strains [6]. Therefore, this parameter was excluded from the comparative test performed in this study, in accordance with NordVal guidelines. The relative accuracy, sensitivity and specificity were evaluated for the PCR method in comparison with the standard culture-based method currently in use for detection of Salmonella [3] according to the NordVal protocol

Table 3: Results obtained by the real-time PCR and the Salmonella BAX PCR in the external validation.

\begin{tabular}{|c|c|c|c|c|c|c|}
\hline \multirow{2}{*}{$\begin{array}{l}\text { Salmonella level } \\
\text { (CFU/25-g sample) }\end{array}$} & \multirow[t]{2}{*}{ No. of samples analyzed } & \multicolumn{5}{|c|}{ Result obtained by the PCR and BAX methods ${ }^{a}$} \\
\hline & & PA & PD & ND & NA & Inconc./+ \\
\hline 1000 & 3 & 3 & 0 & 0 & 0 & 0 \\
\hline 100 & 3 & 3 & 0 & 0 & 0 & 0 \\
\hline 10 & 9 & 7 & 0 & 0 & 2 & 0 \\
\hline 5 & 12 & 10 & I & 0 & 0 & 1 \\
\hline 2 & 12 & 9 & 0 & I & 2 & 0 \\
\hline TOTAL & 39 & 32 & $\mathbf{I}$ & $\mathbf{I}$ & 4 & I \\
\hline
\end{tabular}

a PA: positive by PCR and BAX methods, PD: positive by PCR and negative by BAX, ND: negative by PCR and positive by BAX, NA: negative by PCR and BAX methods, inconc./+: inconclusive result by PCR (need re-analysis) and positive by BAX. 
Table 4: Detailed results from the external validation study.

\begin{tabular}{|c|c|c|c|c|c|}
\hline \multirow[t]{2}{*}{ Salmonella serotype } & \multirow[t]{2}{*}{ Inoculation level (cfu/25 g) } & \multicolumn{3}{|c|}{ Real-time PCR ${ }^{a}$} & \multirow{2}{*}{$\begin{array}{c}\begin{array}{c}\text { Salmonella BAX } \\
\text { Detection System }\end{array} \\
\text { Final result }\end{array}$} \\
\hline & & Ct-value for Salmonella & Ct-value for IAC & Final result & \\
\hline \multirow[t]{13}{*}{ Infantis } & 1000 & 20.05 & 27.89 & Positive & Positive \\
\hline & 100 & 21.66 & 29.09 & Positive & Positive \\
\hline & 10 & 27.14 & 28.68 & Positive & Positive \\
\hline & 10 & 30.59 & 28.95 & Positive & Positive \\
\hline & 10 & 24.92 & 28.89 & Positive & Positive \\
\hline & 5 & 29.42 & 29.09 & Positive & Positive \\
\hline & 5 & 26.57 & 28.81 & Positive & Positive \\
\hline & 5 & 26.29 & 27.66 & Positive & Positive \\
\hline & 5 & 26.63 & 28.79 & Positive & Positive \\
\hline & 2 & 27.70 & 28.42 & Positive & Positive \\
\hline & 2 & 25.68 & 28.08 & Positive & Positive \\
\hline & 2 & 27.86 & 28.56 & Positive & Positive \\
\hline & 2 & 27.20 & 28.90 & Positive & Positive \\
\hline \multirow[t]{13}{*}{ Agona } & 1000 & 22.47 & 28.97 & Positive & Positive \\
\hline & 100 & 24.70 & 27.93 & Positive & Positive \\
\hline & 10 & $>36$ & 29.21 & Negative & Negative \\
\hline & 10 & $>36$ & 29.07 & Negative & Negative \\
\hline & 10 & 26.04 & 28.93 & Positive & Positive \\
\hline & 5 & 28.47 & 28.76 & Positive & Positive \\
\hline & 5 & 32.93 & 28.53 & Positive & Negative \\
\hline & 5 & 29.84 & 28.92 & Positive & Positive \\
\hline & 5 & 32.17 & 27.90 & Positive & Positive \\
\hline & 2 & $>36$ & 28.76 & Negative & Positive \\
\hline & 2 & $>36$ & 29.07 & Negative & Negative \\
\hline & 2 & 33.22 & 28.77 & Positive & Positive \\
\hline & 2 & 30.61 & 27.96 & Positive & Positive \\
\hline \multirow[t]{13}{*}{ Infantis } & 1000 & 19.59 & 29.01 & Positive & Positive \\
\hline & 100 & 23.74 & 28.86 & Positive & Positive \\
\hline & 10 & 25.55 & 28.45 & Positive & Positive \\
\hline & 10 & 24.85 & 28.40 & Positive & Positive \\
\hline & 10 & 26.82 & 28.36 & Positive & Positive \\
\hline & 5 & 29.82 & 29.10 & Positive & Positive \\
\hline & 5 & 29.03 & 28.16 & Positive & Positive \\
\hline & 5 & 24.77 & 28.28 & Positive & Positive \\
\hline & 5 & $>36$ & $>40$ & Inconclusive & Positive \\
\hline & 2 & $28.6 \mathrm{I}$ & 27.88 & Positive & Positive \\
\hline & 2 & 26.24 & 28.79 & Positive & Positive \\
\hline & 2 & 26.02 & 28.82 & Positive & Positive \\
\hline & 2 & $>36$ & 28.63 & Negative & Negative \\
\hline
\end{tabular}

Results from 39 pork meat samples inoculated with salmonella at different levels and analyzed in parallel on-site using the real-time PCR and the Salmonella BAX methods.

a Samples with a $\mathrm{Ct}$ value $>36$ is considered negative if the $\mathrm{Ct}$ value for the IAC is $<40$ and inconclusive if a $\mathrm{Ct}>40$ is obtained for the IAC. According to the Method Directive for the PCR method, re-analysis of the extracted DNA by PCR is then needed.

(Table 1). Two of the artificially contaminated poultry neck-skins were found positive by the real-time PCR method and negative by the reference method. These samples were considered as true positives because according to ISO 20838:2006 [22] no further verification of positive samples is necessary, as the real time PCR analysis contains a DNA probe specific for the target Salmonella gene (ttrRS-
$B C A$ locus). The relative sensitivity for the matrices meat and environmental samples, as well as when all the samples were analyzed together were above $95 \%$, which is the limit considered acceptable according to NordVal [15]. No recommendations concerning the levels for the relative accuracy and relative specificity are given in either the guideline [15] or in the ISO16140 standard [19]. 
In the collaborative study, complete agreement between the real-time PCR method and the culture-based reference method was obtained for all test characteristics for minced pork and veal meat as well as for poultry neck-skin samples. For carcass swabs, one of the samples that were not artificially contaminated was positive when analyzed by one of the laboratories. However, investigations after the finalization of the trial pointed to a mix-up of two samples during the set-up of the PCR plate, which presents a reasonable explanation for this false-positive result. One of the participants was excluded from the study, due to too long transportation time ( $>5$ days) which has a detrimental effect on the PCR master mix. There are some limitations to this study that should be taken into consideration when implementing the method at other laboratories. Firstly, only one brand of PCR thermo cycler was used in the study. It has previously been reported that PCR results might vary considerable between different thermocyclers [12] and it might be necessary to adjust reagent concentrations and the temperature program slightly to optimize the method. Secondly, the enrichment step of the method was only performed at the expert laboratory and pellets were sent out for DNA extraction and PCR analysis. Thus the reproducibility was assessed for the DNA extraction and PCR steps. This procedure was approved in advance by NordVal. The participating laboratories were experienced laboratories that were familiar with culture based methodologies. However, in other guidelines for collaborative studies, such as ISO 16140, it is recommended that the complete procedure is performed by all participating laboratories [19].

In the last part of the study, the robustness of the method was verified externally for artificially contaminated pork samples. No significant difference in the result for the realtime PCR method and a commercial SYBR-Green PCRbased analysis system (BAX) was found. However, results were available after $14 \mathrm{~h}$ for the real-time PCR method, compared with 20-24 h for the BAX system. In this study, two samples inoculated with a very low level (estimated 2 $\mathrm{CFU} / 25 \mathrm{~g}$ ) and two samples inoculated at $10 \mathrm{CFU} / 25 \mathrm{~g}$ were negative in both methods, most likely indicating that no surviving Salmonella actually were present in the sample. Freezing at $-18^{\circ} \mathrm{C}$ will kill some of the inoculated Salmonella cells, thereby affecting the possibility for further detection using BAX or the real-time PCR method. Furthermore, the BAX system failed to detect one sample inoculated with $5 \mathrm{CFU} / 25 \mathrm{~g}$ of $S$. Agona. The same sample was detected using the real-time PCR method although the $\mathrm{Ct}$ value was rather high (Ct value of 33). Finally, two samples (5 CFU/25 g of $S$. Infantis and $2 \mathrm{CFU} / 25 \mathrm{~g}$ of $S$. Agona) were not detected by the real-time PCR method although being positive with the BAX system. For one of these samples, however, the IAC was negative as well, prompting a re-examination of the sample. However, at low inoculation levels the cell number added can vary due of statistical reasons thereby affecting the probability of detection [23]. From these data, it can be concluded that the real-time PCR is equivalent to the BAX system in detecting Salmonella in artificially contaminated meat samples

\section{Conclusion}

In conclusion, the real-time PCR method was validated in comparative and collaborative trials according to guidelines given by NordVal. The PCR method was found to perform well. Results from this study together with published data on selectivity of the real-time PCR assay [6] formed the basis for obtaining NordVal approval as an alternative method for detection of Salmonella in meat and environmental (carcass swabs) samples [24]. After a successful comparison with a commercially available SYBR-Green PCR-based method currently used by a number of meat producers, the real-time PCR method is now being implemented as a routine analysis method by leading poultry and pork producers in Denmark for qualitative detection of Salmonella in raw meat and carcass swabs.

\section{Methods \\ DNA extraction}

Five-ml aliquots from the pre-enrichments were drawn for DNA-extraction. For the automated DNA extraction method, the aliquots were centrifuged at $3000 \times \mathrm{g}$ for 5 min, and DNA-extraction performed on a KingFisher (Thermo Labsystems, Helsinki, Finland), as previously described [13], using a DNA isolation kit for blood, stool, cells and tissue (Magnesil KF, Genomic system, Promega, Madison, WI) as specified by the manufacturer with a total of $75 \mu \mathrm{l}$ of magnetic particles.

\section{Real-time PCR}

A TaqMan real-time PCR method [6], targeting a region within the ttrRSBCA locus, for the specific detection of Salmonella, was employed as previously described [13] using $9 \mu \mathrm{l}$ of the purified DNA as template in a total reaction volume of $25 \mu \mathrm{l}$.

\section{Reference culture based method}

The detection of Salmonella spp. was conducted in accordance with the recommendations from the Nordic Committee on Food Analyses (NMKL) [3] as previously described [13]. However, $25 \mathrm{~g}$ of sample (meat) or one swab was transferred to pre-heated buffered peptone water (1:10, BPW; Oxoid, Basingstoke, United Kingdom) and incubated at $37^{\circ} \mathrm{C}$ for $18 \pm 2 \mathrm{~h}$.

\section{Preparation of inoculum}

To prepare the culture used for artificial inoculation in the comparative and collaborative trials, the Salmonella 
strains were grown overnight at $37^{\circ} \mathrm{C}$ on $5 \%$ blood agar (BA) plates (Statens Serum Institute, Copenhagen, Denmark). One colony of each of the strains was transferred to $4 \mathrm{ml}$ of Nutrient broth with $\mathrm{NaCl}(8.5 \mathrm{~g} / \mathrm{l} \mathrm{NaCl}$ and 20 g/l Nutrient Broth (BD 234000, BD Denmark, Brøndby, Denmark)), vortexed and incubated at $37^{\circ} \mathrm{C}$ for $3-4$ hours. After the incubation, a 10 -fold dilution series in $0.9 \% \mathrm{NaCl}$ solution was performed to determine the concentration of the Salmonella cells. From the dilution series, $0.1 \mathrm{ml}$ from each tube was spread on two 5\% BA plates. The tubes were stored at $2-5^{\circ} \mathrm{C}$ for 16 to 20 hours and the $5 \%$ BA plates were incubated for 16 to 20 hours at $37^{\circ} \mathrm{C}$ and the colonies were counted. The samples were subsequently inoculated from a tube in the dilution series with a known concentration of Salmonella cells. At the time of inoculation, $0.1 \mathrm{ml}$ was spread onto each of two BA plates to estimate the actual inoculation level.

For the on-site validation, three different strains of Salmonella (two $S$. Infantis and one $S$. Agona) previously isolated from pork meat were grown in Brain Heart Infusion (Oxoid $\mathrm{CM} 0225$ ) at $37^{\circ} \mathrm{C}$ for 24 hours resulting in approximately $2 \times 10^{9} \mathrm{CFU} / \mathrm{ml}$. The next day, the cultures were 10 -fold diluted using $0.85 \% \mathrm{NaCl}+1 \%$ peptone.

\section{Sample preparation}

Minced veal and pork meat were purchased at local retailers. Pig carcass swabs and poultry neck-skins were obtained from local abattoirs. Carcass swabs were sampled according to ISO 17604 [25] in accordance with EU directive 2073/2005/EC [26] employing the non-destructive swab method with gauze swabs. The sites on the pig carcass that were swabbed included the ham, back, belly and jowl.

After being transported cooled to the laboratory, the samples were analyzed using the real-time PCR method (DNA extraction and TaqMan PCR, as described above) and the reference culture method. Briefly, Salmonella-free (verified by the NMKL-71 method) fresh meat (25 g) or swab sample (one swab) was transferred to $225 \mathrm{ml}$ (for meat samples) or 1:10 (weight of sample:volume of buffer for swabs) of BPW $\left(37^{\circ} \mathrm{C}\right)$. Different levels of Salmonella (see "Comparative trial" and "Collaborative trial" below) were thereafter added. All the samples were pre-heated to $37^{\circ} \mathrm{C}$ and homogenized by hand for 20 seconds. After preenrichment at $37^{\circ} \mathrm{C}(12 \pm 2 \mathrm{~h}$ for minced meat and neckskins and $14 \pm 1.5$ for swabs), $5 \mathrm{ml}$ aliquots were drawn for DNA-extraction and real-time PCR analysis using $9 \mu \mathrm{l}$ of the extracted DNA. The enrichment was thereafter continued up to 18 hours according to NMKL-71 [3] and further analyzed according to that protocol.

\section{Comparative trial}

The comparative trial was designed and conducted according to the recommendations from NordVal [15]. To evaluate the relative detection level, artificially inoculated samples were analyzed by NMKL-71 and the real-time PCR method as described above. For each of the matrices of minced meat, poultry neck-skins and pig carcass swabs, one sample of $25 \mathrm{~g}$ (for meat and neck-skins) and one swab was left un-inoculated; six were inoculated with 1$10 \mathrm{CFU} / 25 \mathrm{~g}$ and six with 10-100 CFU/25 g. Half of the samples at each inoculation level were inoculated with $S$. Enteritidis CCUG 32352 and the other half with S. Typhimurium CCUG 31969.

To evaluate the relative accuracy, relative specificity and relative sensitivity of the real-time PCR method, minced pork and veal meat ( $\mathrm{n}=60$, artificially contaminated), poultry neck-skins ( $n=60$, artificially contaminated) and swabs from pig carcasses $(n=120$, potentially naturally contaminated) were used, see Table 1 . The samples were analyzed by NMKL-71 and the PCR method as described above. For the minced meat, 30 samples were left un-inoculated; 15 samples were inoculated with S. Livingstone (in-house bacteria culture collection) 1-10 CFU per $25 \mathrm{~g}$ and 15 samples were inoculated with $S$. Typhimurium CCUG 31969 1-10 CFU per 25 g. For the poultry neckskins, 31 samples were left un-inoculated, 15 samples were inoculated with 1-10 CFU $S$. Enteritidis CCUG 32352 per $25 \mathrm{~g}$ and 14 samples were inoculated with 110 CFU S. Typhimurium CCUG 31969 per 25 g. The pig carcass swab samples consisted of 120 non-inoculated samples from a Danish abattoir.

\section{Collaborative trial}

A collaborative trial involving six laboratories was performed to evaluate the robustness and reproducibility of the real-time PCR method testing identical samples. Laboratories belonging to Danish meat producers as well as other laboratories with the equipment used were selected for inclusion in the study. The reason for not including a larger number of participants was that it was not possible to find more than six laboratories that had the equipment and were willing to take part. The collaborative trial was designed and conducted according to the recommendations from NordVal [15] and included minced meat, poultry neck-skins and pig carcass swabs. The participating laboratories received pellets from 18 coded 5-ml samples (six from each matrix, see Table 2).

The samples for the collaborative trial were prepared as described above ("Sample preparation"). To produce the pellets included in the shipment, the supernatant was discarded after the centrifugation step, and the pellet kept at $-20^{\circ} \mathrm{C}$ until shipped on ice to the trial participants. The samples were duplicate samples un-inoculated and inoculated artificially contaminated in duplicate with $S$. Typhimurium CCUG 31369 at two levels (1-10 CFU/25 g and 10-100 CFU/25 g) before enrichment, making it possible to assess the usefulness of the method at various infection levels. 
The Salmonella status of all samples was confirmed by the reference culture method NMKL-71 [3] prior to and after spiking. The stability of the samples was examined using the real-time PCR method immediately after preparation, prior to commencement of the collaborative trial, during the period of analysis, as well after the trial was finished to verify the continued detection of Salmonella. The possible detrimental effect of shipping time at ambient temperature on the real-time PCR results was investigated, by analyzing a ring trial package after storage at room temperature for three days (the maximum shipment time to the participants was two days).

The shipment included a positive DNA control $(1 \mu \mathrm{g} / \mathrm{ml}$ $S$. Typhimurium CCUG 31369) and a negative DNA control $(1 \mu \mathrm{g} / \mathrm{ml}$ Escherichia coli O157 (Sample ID 077, Institute for Reference Materials and Measurements, Geel, Belgium)), a ready-to-use PCR mixture with added IAC, reagents for the magnetically based DNA extraction and the consumables for the DNA extraction and PCR analysis. To minimize any inter-laboratory variability (not attributable to the method performance), all the reagents necessary were supplied by the expert laboratory. At the participating laboratories, DNA extraction and PCR analysis were performed as described above. Real-time PCR at the participating laboratories was performed on an Mx3000 or Mx4000 real-time PCR system (Stratagene, La Jolla, CA). Each participant received a detailed protocol describing the DNA extraction, real-time PCR setup, realtime PCR run, and data analysis as well as a reporting form to record the obtained PCR results to return to the expert laboratory. The participants were also asked to return a file containing the real-time PCR runs. The participating laboratories were asked to use the negative template control (NTC), the process blank (a Salmonellanegative sample processed throughout the entire protocol) and the negative control to assign the threshold.

\section{External validation}

Slices of pork filet were obtained from a local supermarket, and aseptically cut into pieces of 25 grams. Thirtynine pieces of pork filet were inoculated by adding $0.5 \mathrm{ml}$ of an appropriate dilution of Salmonella cells (see "Preparation of inoculum") onto the surface of the meat resulting in the following estimated inoculation levels for each of the three strains: one sample containing approximately $1000 \mathrm{CFU} / 25 \mathrm{~g}$, one sample containing approximately $100 \mathrm{CFU} / 25 \mathrm{~g}$, three samples containing approximately $10 \mathrm{CFU} / 25 \mathrm{~g}$, four samples containing approximately 5 $\mathrm{CFU} / 25 \mathrm{~g}$ and four samples containing approximately 2 $\mathrm{CFU} / 25 \mathrm{~g}$. After inoculation, the meat samples were placed in a stomacher bag and frozen at $-18^{\circ} \mathrm{C}$ for 24 hours in order to induce a slight freezing stress to the Salmonella, resembling the stress during blast-cooling as used by the Danish abattoir.
All 39 samples were analyzed by the real-time PCR method and the BAX Salmonella Detection System (BAX, DuPont Qualicon, Oxoid) using the following protocol. The 25-g sample was thawed overnight at $4^{\circ} \mathrm{C}, 225 \mathrm{ml}$ pre-warmed BPW $\left(37^{\circ} \mathrm{C}\right.$, Oxoid) was added, and the samples were then incubated at $37^{\circ} \mathrm{C}$. After 10 hours, a 5-ml aliquot was drawn for DNA extraction and subsequent real-time PCR analysis as described above. The remaining BPW was further incubated at $37^{\circ} \mathrm{C}$ for an additional 8 hours, and samples were thereafter treated according to the manufacturer's instructions.

\section{Statistical data analysis}

The comparative validation study included three test characteristics: relative accuracy (AC), sensitivity (SE), and specificity (SP) (1) (see Table 1), and these were calculated and defined as previously described [27]. False negative (FN) results were defined as samples giving a negative result with PCR and a positive result with the NMKL-71 method. True positive (TP) results were defined as samples with positive PCR results and negative NMKL71 results when obtained for artificially contaminated samples. Cohen's kappa ( $\kappa)$ was calculated as described by NMKL to quantify the degree of agreement between the two methods [28] ( $\kappa>0.80$ means very good agreement between the methods). This method was also used to evaluate the agreement between the real-time PCR and the BAX method in the on-site validation study.

For the collaborative validation study, the test reports and the real-time PCR analyses from the participating laboratories were carefully evaluated on return to the expert laboratory, and the results were approved for inclusion in the statistical analysis, unless they fell into at least one of the following two categories: (i) obvious performance deviation from the protocol and (ii) failed PCR analysis as shown in the included controls. The results obtained in the collaborative trial were analyzed according to the recommendations from NordVal [15]. SP was calculated for the un-inoculated samples by the following equation: SP $=(1-[\mathrm{FP} / \mathrm{N}-]) \times 100 \%$, where $\mathrm{N}-$ refers to the total number of samples not inoculated with Salmonella. SE was calculated for each level of spiking by the following equation: $\mathrm{SE}=(\mathrm{TP} / \mathrm{N}+) \times 100 \%$, where $\mathrm{N}+$ refers to the number of artificially contaminated samples. AC was calculated for all levels of spiking by the following equation: $\mathrm{AC}=([\mathrm{PA}+\mathrm{NA}+\mathrm{FP}] / \mathrm{N}) \times 100 \%$, where $\mathrm{N}$ refers to the number of samples tested.

\section{Authors' contributions}

CL participated in the design of the study, performed part of the experimental work for the collaborative study, performed the statistical analysis and drafted the manuscript. MHJ and MK planned and performed the experimental work on the comparative study. FH planned and per- 
formed the experimental work for the external validation. $\mathrm{JH}$ conceived the study, obtained funding, helped to draft and critically read the manuscript. All authors read and approved the final manuscript.

\section{Acknowledgements}

Kirsten Michaëlis, Pia Engelsmann and Julia Christensen are acknowledged for excellent technical assistance. All authors were financially supported by the Danish Directorate for Food, Fisheries and Agri-Business (DFFE) grant 3414-04-01032, and the European Union funded Integrated Project BIOTRACER (contract FOOD-2006-CT-036272) under the 6th RTD Framework.

\section{References}

I. Berends BR, Van KF, Mossel DA, Burt SA, Snijders JM: Impact on human health of Salmonella spp. on pork in The Netherlands and the anticipated effects of some currently proposed control strategies. Int J Food Microbiol 1998, 44:2 I 9-229.

2. Hald T, Vose D, Wegener HC, Koupeev T: A Bayesian approach to quantify the contribution of animal-food sources to human salmonellosis. Risk Anal 2004, 24:255-269.

3. Nordic Method Committee on Food Analysis: NMKL method no 7I, Salmonella. Detection in food. Åbo, Finland 5th edition. 1999.

4. Lübeck PS, Hoorfar J: PCR technology and applications to zoonotic food-borne bacterial pathogens. Methods Mol Biol 2003, 2 1 6:65-84.

5. Perelle S, Dilasser F, Malorny B, Grout J, Hoorfar J, Fach P: Comparison of PCR-ELISA and LightCycler real-time PCR assays for detecting Salmonella spp. in milk and meat samples. Mol Cell Probes 2004, I 8:409-420.

6. Malorny B, Paccassoni E, Fach P, Bunge C, Martin A, Helmuth R: Diagnostic real-time PCR for detection of Salmonella in food. Appl Environ Microbiol 2004, 70:7046-7052.

7. Guy RA, Kapoor A, Holicka J, Shepherd D, Horgen PA: A rapid molecular-based assay for direct quantification of viable bacteria in slaughterhouses. J Food Prot 2006, 69:1265-1272.

8. Cheung PY, Chan CW, Wong W, Cheung TL, Kam KM: Evaluation of two real-time polymerase chain reaction pathogen detection kits for Salmonella spp. in food. Lett Appl Microbiol 2004, 39:509-5I5.

9. Silbernagel K, Jechorek R, Carver C, Barbour WM, Mrozinski P: Evaluation of the BAX system for detection of Salmonella in selected foods: collaborative study. J AOAC Int 2003, 86: II 49-59.

10. Patel JR, Bhagwat AA, Sanglay GC, Solomon MB: Rapid detection of Salmonella from hydrodynamic pressure-treated poultry using molecular beacon real-time PCR. Food Microbiol 2006, 23:39-46.

II. Malorny B, Made D, Teufel P, Berghof-Jager C, Huber I, Anderson A, Helmuth R: Multicenter validation study of two blockcyclerand one capillary-based real-time PCR methods for the detection of Salmonella in milk powder. Int J Food Microbiol 2007, I | 7:21 I-218.

12. Reynisson E, Josefsen MH, Krause M, Hoorfar J: Evaluation of probe chemistries and platforms to improve the detection limit of real-time PCR. J Microbiol Methods 2006, 66:206-2 I6.

13. Josefsen MH, Krause M, Hansen F, Hoorfar J: Optimization of a I 2hour TaqMan PCR-based method for detection of Salmonella bacteria in meat. Appl Environ Microbiol 2007, 73:3040-3048.

14. Qvist S: NordVal: A Nordic system for validation of alternative microbiological methods. Food Control 2007, I 8: I I3-I I 7.

15. NordVal protocol for the validation of alternative microbiological methods [http://www.nmkl.org/NordVal/ Validation protocol2007.doc]

16. Burkardt $\mathrm{H}$ ): Standardization and quality control of PCR analyses. Clin Chem Lab Med 2000, 38:87-91.

17. Hoorfar J, Ahrens P, Rådström P: Automated 5' nuclease PCR assay for identification of Salmonella enterica. J Clin Microbiol 2000, 38:3429-3435.

18. Technical University of Denmark: Annual Report on Zoonoses in Denmark 2006. Søborg, Denmark 2006.
19. International Organisation for Standardization: ISO /6/40:2003 Microbiology of food and animal feeding stuffs-Protocol for the validation of alternative methods. Geneva, Switzerland 2003.

20. International Organisation for Standardization: ISO 6579:2002 Microbiology of food and animal feeding stuffs - Horizontal method for the detection of Salmonella spp. Geneva, Switzerland 2002.

21. Memorandum of Equvivalence. Comparison of NMKL and ISO methods for methods given in the Annex of the EU Commission Regulation (EC 2073/2005) on microbiological criteria [http://www.nmkl.org/Publikasjoner/Sammenlikning/ NMKL-ISO\%20equivalent.pdf]

22. International Organisation for Standardization: ISO 20838:2006 Microbiology of food and animal feeding stuffs - Polymerase chain reaction (PCR) for the detection of food borne pathogens - Requirements for amplification and detection for qualitative methods. Geneva, Switzerland 2006.

23. Knutsson R, Blixt $Y$, Grage $H$, Borch $E$, Rådström P: Evaluation of selective enrichment PCR procedures for Yersinia enterocolitica. Int J Food Microbiol 2002, 73:35-46.

24. NordVal certificate no 031 [http://www.nmkl.org/NordVal/Ser tifikater/NO31-2.pdf]

25. International Organisation for Standardization: ISO / 7604:2003 Microbiology of food and animal feeding stuffs - Carcass sampling for microbiological analysis. Geneva, Switzerland 2003.

26. European Commission: Commission regulation (EC) No 2073/2005 of 15 November 2005 on microbiological criteria for foodstuffs Official Journal of the European Union, L 338/I; 2005.

27. Krause $M$, Josefsen $M H$, Lund $M$, Jacobsen NR, Brorsen L, Moos $M$, Stockmarr A, Hoorfar J: Comparative, collaborative, and onsite validation of a TaqMan PCR method as a tool for certified production of fresh, campylobacter-free chickens. Appl Environ Microbiol 2006, 72:5463-5468.

28. Nordic Method Committee on Food Analysis: NMKL procedure no. 20. Evaluation of results from qualitative methods. Oslo, Norway 2007.

Publish with Bio Med Central and every scientist can read your work free of charge

"BioMed Central will be the most significant development for disseminating the results of biomedical research in our lifetime. "

Sir Paul Nurse, Cancer Research UK

Your research papers will be:

- available free of charge to the entire biomedical community

- peer reviewed and published immediately upon acceptance

- cited in PubMed and archived on PubMed Central

- yours - you keep the copyright

BioMedcentral 
Diagnostic PCR: Comparative sensitivity of four probe chemistries. Josefsen, M.H., C. Löfström, H.M. Sommer and J. Hoorfar.

Molecular and Cellular Probes (2009) 23:201-203. 
Short Communication

\title{
Diagnostic PCR: Comparative sensitivity of four probe chemistries
}

\author{
Mathilde H. Josefsen*, Charlotta Löfström, Helle M. Sommer, Jeffrey Hoorfar \\ National Food Institute, Technical University of Denmark, Mørkhøj Bygade 19, DK-2860 Søborg, Denmark
}

\section{A R T I C L E I N F O}

\section{Article history:}

Received 17 December 2008

Accepted 27 February 2009

Available online 6 March 2009

Keywords:

Real-time PCR

Probe

LNA

MGB

Scorpion

TaqMan

\begin{abstract}
A B S T R A C T
Three probe chemistries: locked nucleic acid (LNA), minor groove binder (MGB) and Scorpion were compared with a TaqMan probe in a validated real-time PCR assay for detection of food-borne thermotolerant Campylobacter. The LNA probe produced significantly lower Ct-values and a higher proportion of positive PCR responses analyzing less than 150 DNA copies than the TaqMan probe. Choice of probe chemistry clearly has an impact on the sensitivity of PCR assays, and should be considered in an optimization strategy.
\end{abstract}

(c) 2009 Elsevier Ltd. All rights reserved.
An increasing number of alternative probe chemistries for realtime PCR are being marketed, such as minor groove binder (MGB) [1], Molecular Beacon [2], Scorpion [3], locked nucleic acid (LNA) [4] and Light Upon eXtension (LUX) [5]. The alternative probe technologies are based on different chemistries and claim to have some advantages compared with the conventional TaqMan DNA probes. However, there is a lack of diagnostic comparative studies. We thus compared three of the probe chemistries, namely LNA, MGB and the Scorpion technology (uni- and bi-molecular) to a TaqMan probe used in routine testing (Table 1 ). The probes were designed by the manufacturers to comply with the existing TaqMan probe and primers for an already validated real-time PCR assay for detection of food-borne thermotolerant Campylobacter (Campylobacter jejuni, Campylobacter coli and Campylobacter lari) [6].

A prerequisite for successful probe-based real-time PCR is a strong binding of the probe during annealing. This is obtained by designing probes with a $5-10{ }^{\circ} \mathrm{C}$ higher melting temperature $\left(T_{\mathrm{m}}\right)$ than the primers. For TaqMan probes, this often results in 25-30 nucleotide long probes, which, in the case of a short specific region, can be difficult to design.

LNA probes have certain nucleic bases substituted by LNA monomers, i.e. nucleic acid analogs containing a $2^{\prime}-0,4^{\prime}-C$ methylene bridge, restricting the flexibility of the ribofuranose ring and rendering the monomer in a rigid bicyclic formation. This enhances the hybridization performance of LNA containing probes compared to classical TaqMan probes, and allows shorter probe designs. The incorporation of LNA monomers will increase the thermal stability

\footnotetext{
* Corresponding author. Tel.: +45 22844734

E-mail address: mhjo@food.dtu.dk (M.H. Josefsen).
}

of a duplex complementary DNA significantly (up to $8{ }^{\circ} \mathrm{C}$ per substitution) [7].

MGB probes have a moiety attached to the $3^{\prime}$-end of the probe, which folds into the minor groove of the formed DNA duplex and stabilizes the probe hybridization. Hence, MGB probes can be shorter (13-20 bases), and still possess similar melting temperatures as TaqMan probes [8]. In MGB probes the standard quencher TAMRA has been replaced by a non-fluorescent quencher (NFQ) acting as energy transfer acceptor from the reporter dye, but not emitting a fluorescent signal of its own. This results in a lower fluorescent background, improving the spectral discrimination and the ease of multiplexing [9].

Claimed advantages of these short probes are improved sensitivity towards single-base mismatches (specificity), ease of design and an improved signal-to-noise ratio, partly due to reduced fluorescence from spurious binding and partly due to the fact that the quencher is in closer proximity to the reporter dye [8].

The uni-molecular Scorpion has a Molecular Beacon tail linked to the $5^{\prime}$-end of the primer via a PCR-blocker. This probe anneals to the template DNA, and the DNA polymerase extends it, creating a complementary probe site. Following the next denaturation, the probe element will fold up and anneal to this site, rather than entering the hairpin loop conformation again, because it will be more kinetic favourable [10]. This event opens the hairpin loop, eliminating the quenching of the fluorophore and increasing the real-time PCR signal. The bi-molecular Scorpion consists of a fluorescently labeled probe coupled to a primer by a PCR-blocker. It is annealed to a complementary oligo bearing a quencher at the $3^{\prime}$-end. The mechanism of action is similar to that of the unimolecular, the probe will anneal to the newly synthesised DNA 
Table 1

Primers and probes for detection of thermotolerant Campylobacter by real-time PCR.

\begin{tabular}{|c|c|c|c|c|}
\hline Primer/Probe & Sequence & Bases & $T_{\mathrm{m}}\left[{ }^{\circ} \mathrm{C}\right]^{\mathrm{e}}$ & Manufacturer \\
\hline OT-1559 & CTGCTTAACACAAGTTGAGTAGG & 23 & 55.7 & DNA Tech. \\
\hline $18-1$ & TTCCTTAGGTACCGTCAGAA & 20 & 54.6 & DNA Tech. \\
\hline TaqMan & FAM-TGTCATCCTCCACGCGGCGTTGCTGC-TAMRA & 26 & 77.9 & DNA Tech. \\
\hline MGB & FAM-TGTCATCCTCCACGCGG-MGB-NFQ & 17 & 69.0 & $\mathrm{ABI}$ \\
\hline LNA $^{\mathrm{a}}$ & FAM-CA + TCC + TCCACGCGGCG + TTGC-BHQ1 & 20 & 76.0 & Sigma-Proligo \\
\hline Scorpion ${ }^{\mathrm{b}}$ R_Sc1 & FAM-CCGCGTGGAGGATGAC-HEG-TTCCTTAGGTACCGTCAGAA & 37 & 68.9 & DxS \\
\hline Scorpion $^{\mathrm{C}}$ P1_Q & GTCATCCTCCACGCGG-Dabcyl & 16 & 50.9 & DxS \\
\hline Scorpion ${ }^{\mathrm{d}}$ R_Sc2 & FAM-CCCGCGTGGAGGATGACGCGGG-Dabcyl-HEG-TTCCTTAGGTACCGTCAGAA (Uni-molecular) & 44 & 74.2 & DxS \\
\hline
\end{tabular}

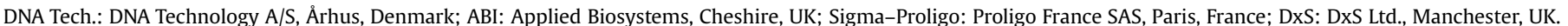

${ }^{a}$ The + in front of the nucleotide indicates an LNA monomer substitution.

b Reverse primer linked together with the fluorescent probe (bi-molecular format).

c Separate oligo labeled with a dark quencher (bi-molecular format).

d Reverse primer linked together with the probe element (a Molecular Beacon tail labeled with a reporter and quencher dye at each end, uni-molecular format).

e The melting temperature of the probes and primers as stated by the manufacturers.

template, and emit fluorescence since it is separated from the quencher $[3,10,11]$.

In this study, a statistically based comparison analysis was performed to identify the optimal probe chemistry for an already validated real-time PCR assay for detection of thermotolerant Campylobacter. The assay is intended for use in industrial routine testing of whole chicken carcass rinse samples, and therefore a high level of robustness and sensitivity is required.

A 5'-nuclease real-time PCR method for the specific detection of thermotolerant Campylobacter was performed essentially as described earlier [12] on an Mx3005P (Stratagene, La Jolla, CA). Fluorescence measurements were obtained online and analyzed with the MxPro-Mx3005P software (version 3.00). The threshold was assigned using the software option: background-based threshold, i.e. the standard deviation of all amplifications was determined from cycle 5 to 9 , and this value was multiplied by a background sigma multiplier of 10 .

(i) Each of the five probes (Table 1) was applied under standardized PCR conditions in the following concentrations: 50, $75,100,200,250,300,400$ and $500 \mathrm{nM}$ in real-time PCR on triplicates of $3-3 \times 10^{5}$ copies/PCR of reference DNA (C. jejuni CCUG 11284). The parameters applied to evaluate the optimal probe concentration were cycle threshold $(\mathrm{Ct})$-values, background fluorescence, dR last (final fluorescence reading - initial fluorescence reading) and finally the variation between the triplicates.

(ii) The three probes (TaqMan, MGB and LNA) were run in the concentration determined as optimal in real-time PCR on triplicates of $3-3 \times 10^{5}$ copies/PCR reference DNA (C. jejuni CCUG 11284). The parameters applied to evaluate the performance of the probes were as mentioned above, including amplification efficiency $(\mathrm{AE})$ calculated as: $\mathrm{AE}=10^{(-1 / \text { slope })}-1$ [13].

(iii) The sensitivity of the TaqMan and the LNA probes was examined by performing replicate PCR on different levels of DNA copies. As shown in Table 2, multiple replicates of PCR were tested on $3,10,15,30,50,100,150,300,3000,30,000$, 300,000 and $3,000,000$ copies/PCR of reference DNA (C. jejuni CCUG 11284). The relationship between the proportion positive from each replicate and the number of DNA copies of $C$. jejuni was estimated by analysis in a generalized linear model with a logit link function for the LNA and the TaqMan probes using the SAS software (SAS Institute, Cary, NC, USA). The dependency of the DNA level was described by a regressor.

The best performance of the TaqMan probe was obtained applying a $100-n M$ concentration. At this concentration, the lowest $\mathrm{Ct}$-values and background fluorescence and the best splitting of the probe were observed. The MGB probe had an equally optimal performance at concentrations of 200 and $250 \mathrm{nM}$, where the Ctvalues were the lowest and the background fluorescence was in an acceptable range. The best splitting of the probe was observed at $200 \mathrm{nM}$. Applying the LNA probe at a concentration of $75 \mathrm{nM}$ gave the lowest Ct-values, acceptable background fluorescence and an optimal splitting of the probe. The Scorpion chemistry, in both the uni- and bi-molecular format, was not compatible with the realtime PCR assay. Non-amplification related degradation of the probe element was observed from the very first PCR cycle, until it reached plateau. Theoretically, the Scorpion chemistry should be more sensitive than the other probes tested, since the probing mechanism is intra-molecular, and the quenching mechanism predominantly collisional in contrast to TaqMan, LNA and MGB probes that rely on 'through-space' quenching [14]. The PCR products obtained when Scorpion probes were applied were run in gel electrophoresis (1.5\% agarose gel, $100 \mathrm{~V}, 30 \mathrm{~min}$ ), and the presence of correct-sized bands was observed. Several optimization steps were performed as recommended by the manufacturer (David Withcombe, DxS Ltd., personal communication), i.e. the amount of $\mathrm{MgCl}_{2}$ was altered, the probe was run in a pre-fabricated master mix (DyNAmo qPCR Kit, Finnzymes, Espoo, Finland), with a different DNA polymerase (DyNAzyme, Finnzymes) and finally the thermal profile was optimized. However, none of the optimization steps rectified the problem of probe degradation.

As shown in Table 3, the comparison of the three probes at optimal concentrations revealed that the LNA probe produced slightly lower Ct-values than the TaqMan probe and especially the MGB probe. The Ct-values obtained by the LNA probe was significantly $(P<0.05$, analysis of variance) lower than those obtained by

Table 2

Number of replicate PCR analysis performed and the number of positives with the LNA and the TaqMan probes at the different levels of DNA copies from C. jejuni CCUG 11284.

\begin{tabular}{lccc}
\hline DNA copies/PCR & Total no. of replicates & \multicolumn{2}{c}{ No. of positives } \\
\cline { 3 - 4 } & & LNA probe & TaqMan probe \\
\hline 3 & 30 & 0 & 0 \\
10 & 20 & 1 & 0 \\
15 & 20 & 6 & 1 \\
30 & 46 & 43 & 23 \\
50 & 10 & 9 & 10 \\
100 & 30 & 30 & 28 \\
150 & 30 & 30 & 30 \\
300 & 46 & 46 & 46 \\
3,000 & 36 & 36 & 36 \\
30,000 & 6 & 6 & 6 \\
300,000 & 6 & 6 & 6 \\
$3,000,000$ & 6 & 6 & 6 \\
\hline
\end{tabular}


Table 3

Cycle threshold (Ct)-values and amplification efficiencies obtained comparing the three probe types at optimal concentrations analyzing triplicate samples.

\begin{tabular}{llll}
\hline DNA [copies/PCR] & TaqMan [100 nM] & MGB [200 nM] & LNA [75 nM] \\
\hline $3 \times 10^{5}$ & 18.83 & 19.40 & 18.33 \\
& 18.50 & 19.34 & 18.52 \\
$3 \times 10^{4}$ & 18.34 & 18.80 & 17.59 \\
& 22.73 & 23.13 & $22.05^{*}$ \\
& 22.79 & 22.60 & $21.53^{*}$ \\
$3 \times 10^{3}$ & 22.91 & 22.48 & $21.49^{*}$ \\
& 26.86 & 27.21 & $26.72^{*}$ \\
& 26.84 & 26.85 & $25.60^{*}$ \\
$3 \times 10^{2}$ & 26.80 & 27.51 & $26.08^{*}$ \\
& 30.78 & 31.99 & $30.87^{* *}$ \\
& 30.72 & 31.84 & $30.24^{* *}$ \\
$3 \times 10^{1}$ & 30.64 & 31.76 & $30.34^{* *}$ \\
& 34.37 & 35.44 & $33.47^{*}$ \\
Amplification efficiency & 0.786 & 35.24 & $33.11^{*}$ \\
\hline
\end{tabular}

*The Ct-values were significantly (analysis of variance, $P<0.05$ ) lower using the LNA probe.

**The Ct-values were significantly (analysis of variance, $P<0.05$ ) lower using the LNA and the TaqMan probe.

The Scorpion chemistry, in both the uni- and bi-molecular format, was not compatible with the real-time PCR assay.

the MGB probe for 4 out of 5 DNA levels. The background fluorescence of the LNA probe (16,000-34,000 fluorescence units) was higher than both that of the TaqMan (12,000-20,000) and MGB probe $(14,000-21,000)$, and the splitting of the LNA probe was slightly inferior (approx. 3\% less than the TaqMan and MGB probes). The variation between the triplicates was negligible for all three probes. The highest amplification efficiency was however achieved using the LNA probe.

The statistical model applied for the sensitivity analysis accounted for the nature of the data setup by adding a variable dividing the amount of DNA copies in to two levels, i.e. a low level up to 150 DNA copies, and a high level above 150 DNA copies. The results of the sensitivity analysis showed that the LNA probe was significantly $(P=0.0001)$ more sensitive than the TaqMan probe analyzing low levels of DNA copies, and that the proportion of positive responses depended on the level of DNA (Table 2). In the high level ( $>150$ DNA copies) no difference in sensitivity was observed between the two probe types.

This is in accordance with the findings of Costa et al. (2004), who showed LNA probes to be more sensitive than conventional DNA probes testing fetal DNA in maternal serum samples. This was attributed to an improved PCR efficiency when using a shorter probe due to less amplification interference [15]. A comparative study on sensitivity formerly performed by the present authors (Reynisson et al. 2006), did likewise indicate an improved performance of an LNA probe compared with a TaqMan probe and a unimolecular Scorpion detecting Salmonella in a range of sample matrices. The LNA probe reached higher fluorescence plateaus, and produced lower Ct-values and standard deviations [16].

The advantages of the LNA probes are similar to MGB probes. They both belong to the short probe types with a high thermal duplex stability, and they are both reported to have an improved signal-to-noise ratio due to reduced signal from spurious binding and reduced distance between the fluorophore and quencher. However, the MGB probe was not found to be superior to the TaqMan probe in this study. Nevertheless, the sensitivity of an LNA probe was reported similar to that of an MGB probe by Letertre et al. (2003) amplifying enterotoxin genes from Staphylococcus aureus
[17]. In PCR testing for hepatitis B by Zhao et al. (2005) also found an MGB probe to have a wider linear detection range and a lower limit of detection than a TaqMan probe [18]. As the data and discussion presented above emphasizes, it is necessary to evaluate the optimal probe type for each PCR assay separately, as conclusions drawn from one comparison study are not necessarily generally applicable.

In conclusion, optimizing the probe chemistry is a convenient way to improve sensitivity of a PCR assay. In the assay evaluated in this study, the Ct-values were improved when using an LNA probe and higher amplification efficiency was observed. The LNA probe was likewise proven to be the most sensitive of the chemistries. This probe chemistry presents an interesting alternative to TaqMan probe-based real-time PCR assays, not least due to its sensitivity towards single-base mismatches, ease of design and improved signal-to-noise ratio.

\section{Acknowledgments}

The work was supported in part by the European Union-funded Integrated Project BIOTRACER (Contract 036272) under the 6th RTD Framework. The authors thank Liselotte Folling for excellent technical assistance.

\section{References}

[1] Afonina IA, Reed MW, Lusby E, Shishkina IG, Belousov YS. Minor groove binder-conjugated DNA probes for quantitative DNA detection by hybridization-triggered fluorescence. BioTechniques 2002;32:940-4. 946-9.

[2] Piatek AS, Tyagi S, Pol AC, Telenti A, Miller LP, Kramer FR, et al. Molecular beacon sequence analysis for detecting drug resistance in Mycobacterium tuberculosis. Nat Biotechnol 1998;16:359-63.

[3] Whitcombe D, Theaker J, Guy SP, Brown T, Little S. Detection of PCR products using self-probing amplicons and fluorescence. Nat Biotechnol 1999;17:804-7.

[4] Braasch DA, Corey DR. Locked nucleic acid (LNA): fine-tuning the recognition of DNA and RNA. Chem Biol 2000;55:1-7.

[5] Nazarenko I, Lowe B, Darfler M, Ikonomi P, Schuster D, Rashtchian A. Multiplex quantitative PCR using self-quenched primers labeled with a single fluorophore. Nucleic Acids Res 2002;30:e37.

[6] Krause M, Josefsen MH, Lund M, Jacobsen NR, Brorsen L, Moos M, et al Comparative, collaborative, and on-site validation of a TaqMan PCR method as a tool for certified production of fresh, Campylobacter-free chickens. Appl Environ Microbiol 2006;72:5463-8.

[7] Kumar R, Singh SK, Koshkin AA, Rajwanshi VK, Meldgaard M, Wengel J. The first analogues of LNA (locked nucleic acids): phosphorothioate-LNA and 2'-thio-LNA. Bioorg Med Chem Lett 1998;8:2219-22.

[8] Kutyavin IV, Afonina IA, Mills A, Gorn VV, Lukhtanov EA, Belousov ES, et al. 3' minor groove binder-DNA probes increase sequence specificity at PCR extension temperatures. Nucleic Acids Res 2000;28:655-61.

[9] Applied Biosystems. TaqMan MGB probes. SDS News 2002;17:1-2.

[10] Schena L, Nigro F, Ippolito A, Gallitelli D. Real-time quantitative PCR: A new technology to detect and study phytopathogenic and antagonistic fungi. Eur J Plant Pathol 2004;110:893-908.

[11] DxS. Diagnostic innovations. The Scorpion reaction. Available from: http:// www.dxsdiagnostics.com/Content/TheScorpionsReaction.aspx.

[12] Josefsen MH, Jacobsen NR, Hoorfar J. Enrichment followed by quantitative PCR both for rapid detection and as a tool for quantitative risk assessment of food-borne thermotolerant campylobacters. Appl Environ Microbiol 2004;70: 3588-92.

[13] Klein D, Janda P, Steinborn R, Müller M, Salmons B, Günzburg WH. Proviral load determination of different feline immunodeficiency virus isolates using real-time polymerase chain reaction: influence of mismatches on quantification. Electrophoresis 1999;20:291-9.

[14] Solinas A, Brown LJ, McKeen C, Mellor JM, Nicol J, Thelwell N, et al. Duplex Scorpion primers in SNP analysis and FRET applications. Nucleic Acids Res 2001;29:E96.

[15] Costa JM, Ernault P, Olivi M, Gaillon T, Arar K. Chimeric LNA/DNA probes as a detection system for real-time PCR. Clin Biochem 2004;37:930-2.

[16] Reynisson E, Josefsen MH, Krause M, Hoorfar J. Evaluation of probe chemistries and platforms to improve the detection limit of real-time PCR. J Microbiol Methods 2006;66:206-16.

[17] Letertre C, Perelle S, Dilasser F, Arar K, Fach P. Evaluation of the performance of LNA and MGB probes in 5'-nuclease PCR assays. Mol Cell Probes 2003;17: 307-11.

[18] Zhao JR, Bai YJ, Zhang QH, Wan Y, Li D, Yan XJ. Detection of hepatitis B virus DNA by real-time PCR using TaqMan-MGB probe technology. World J Gastroenterol 2005;11:508-10. 
Quantification of viable Campylobacter in fresh chicken carcass rinse by real-time PCR and propidium monoazide as a novel strategy for risk assessment. Josefsen, M.H., C. Löfström, T.B. Hansen, L.S. Christensen, J.E. Olsen and J. Hoorfar.

In Preparation for Applied and Environmental Microbiology (2009) 


\section{Quantification of viable Campylobacter in fresh chicken carcass rinse by}

\section{real-time PCR and propidium monoazide as a novel strategy for risk}

\section{assessment}

M.H. Josefsen ${ }^{1 *}$, C. Löfström ${ }^{1}$, T.B. Hansen ${ }^{1}$, L.S. Christensen ${ }^{1}$, J.E. Olsen ${ }^{2}$ \& J. Hoorfar ${ }^{1}$

${ }^{1}$ National Food Institute, Technical University of Denmark, Mørkhøj Bygade 19, 2860 Søborg, Denmark.

${ }^{2}$ Department of Veterinary Disease Biology, Faculty of Life Sciences, University of Copenhagen, Stigbøjlen 4, 1870 Frederiksberg C, Denmark.

For submission to Applied and Environmental Microbiology

Running title: Real-time PCR quantification of viable Campylobacter

Keywords: Real-time PCR, Quantification, Propidium monoazide, Campylobacter, Chicken

* Corresponding author: Mathilde H. Josefsen, National Food Institute, Mørkhøj Bygade 19, 2860 Søborg, Denmark. Phone: +45-22844734. E-mail: mhjo@food.dtu.dk 


\begin{abstract}
Mitigation strategies for Campylobacter are focusing increasingly on post-slaughter reduction of the number of cells, emphasizing the need for rapid and reliable quantitative detection of only viable Campylobacter. We present a quantitative real-time PCR (Q-PCR) method for detection and enumeration of foodborne thermotolerant Campylobacter (C. jejuni, C. coli and C. lari), combined with a simple propidium monoazide (PMA) sample treatment, which generates signal from only viable and viable but non-culturable (VBNC) Campylobacter with an intact membrane in chicken carcass rinse. The performance of the method was evaluated by assessing the contribution to variability from individual chicken carcass rinse matrices, different species of Campylobacter, and the efficiency of DNA extraction with differing cell inputs. Finally, the method was compared to culture-based enumeration on 50 naturally infected Danish chickens from a Campylobacterpositive flock. The amplification efficiency of the Q-PCR method was found to be unaffected by chicken rinse matrix and species of Campylobacter. The relationship between cell input and $\mathrm{Ct}$ value was linear $\left(R^{2}=0.993\right)$, with a quantification range from $1 \times 10^{2}-1 \times 10^{7} \mathrm{CFU} / \mathrm{ml}$. The correlation between the Campylobacter counts obtained by PMA-PCR and culture on naturally contaminated chicken carcass rinse samples was good $\left(R^{2}=0.8436\right)$. In conclusion, this study presents a reliable diagnostic tool for producing accurate quantitative data on viable Campylobacter in chicken carcass rinse for risk assessment. The proposed method does not detect DNA from dead Campylobacter, but recognises the infectious potential of the VBNC state, and is thereby able to assess the outcome and impact of new mitigation strategies.
\end{abstract}




\section{Introduction}

As Campylobacter remains the leading cause of food borne bacterial gastrointestinal disease in large parts of the developed world (30), affecting general health and having wide socioeconomic impact, much effort is devoted to develop and improve detection methods. The objective of this is partly to be able to supply consumers with fresh Campylobacter-free products, and perhaps more importantly, to gain more insight in the epidemiology of Campylobacter in order to improve mitigation strategies and make them more efficient.

Traditional culture-based detection of Campylobacter including enrichment, isolation and confirmation is a time-consuming procedure requiring 5 to 6 work days $(3,12)$. Another drawback of culture-based detection of Campylobacter is that these bacterial cells may enter a viable but non-culturable (VBNC) state, in which their potential to cause human infection is controversial (32). The introduction of the quantitative real-time PCR (Q-PCR) technology has enabled a more rapid, sensitive and less work demanding quantitative detection. Q-PCR methods for food borne Campylobacter jejuni and C. coli in poultry, which is recognized as an important source of human Campylobacter infections, have been published $(9,10,13,33,39)$. However, bearing in mind that the majority of current mitigation strategies regarding Campylobacter are focused on postslaughter reduction of the number of bacterial cells on the chicken carcass, the usefulness of these Q-PCR methods for risk assessment could be limited, since they detect all Campylobacter present in a sample, including the dead cells.

The Q-PCR method described in the present study quantifies the three major foodborne Campylobacter species ( $C$. jejuni, $C$. coli and $C$. lari), thereby covering all possible prevalence shifts and co-infections. The method was previously validated according to the Nordic organization for validation of alternative microbiological methods (NordVal), and is certified for detection of Campylobacter in chicken, cloacae swabs and boot swabs. The current study confirms its suitability for quantification of Campylobacter in chicken carcass rinse. Furthermore, a propidium monoazide (PMA) sample treatment step has been incorporated into the method (PMA-PCR), assuring quantification of only viable Campylobacter cells with intact membrane. Propidium monoazide is a chemical alteration (additional azide group) of propidium iodide ( $\mathrm{PI}$ ), one of the most frequently applied membrane-impermeable dyes in flow cytometry, and it can be expected to have the same permeability potential as PI. This is of great value in a food safety perspective, since PI only penetrates permeabilized cells, and not the cells with intact membranes (including the Campylobacter VBNC state), which can be resuscitated and therefore hold the potential of 
infection (26). This study, for the first time, establishes the correlation between PMA-PCR and culture for a large number of naturally infected Danish broilers. 


\section{Materials and Methods}

\section{Experimental design}

Preliminary optimization and investigation of the quantitative aspect: Preliminary experiments were performed to determine the (i) optimal volume $(50,100$ or $500 \mathrm{ml}$ ) applied for rinsing of chicken carcasses, (ii) optimal volume to draw from the chicken carcass rinse $(1,5$ or $10 \mathrm{ml})$ for DNA extraction (iii) if DNA extraction was needed or if Q-PCR could be performed directly on chicken carcass rinse and finally (iiii) optimal DNA template volume (5 or $10 \mu \mathrm{l})$ for Q-PCR.

Furthermore, the recovery of Campylobacter with the applied rinsing procedure was examined. Firstly, two Campylobacter-positive chickens were purchased at retail level and rinsed as described, four times in succession. From each chicken carcass rinse, ten-fold serial dilutions ranging from $10^{\circ}$ to $10^{-2}$ were prepared, and the number of Campylobacter was determined in duplicate by culture as described. Secondly, eight Campylobacter-free chickens were purchased at retail level and split in half. From one half, the Campylobacter-negative status of the chicken was confirmed by culture of the chicken carcass rinse as described. The second halves were inoculated with $5 \times 10^{2}, 5 \times 10^{3}, 5 \times 10^{4}$ and $5 \times 10^{5}$ CFU C. jejuni CCUG 11284 . The inoculation was performed by placing $10 \mu \mathrm{l}$ droplets of bacterial suspension at 25 equally distributed positions on the chicken skin surface. To ensure adherence and simulate natural contamination as far as possible, the chicken was placed unwrapped for 1 hour at room temperature followed by 24 hours at $5^{\circ} \mathrm{C}$ wrapped in a sterile plastic bag. Subsequently, the number of Campylobacter on the inoculated chickens was determined by culture of the chicken carcass rinse as described.

Variation attributable to the matrix: A prerequisite for successful quantification of Campylobacter is to describe the natural variation within the matrix in question. Quantification would be flawed and encumbered with uncertainties if large natural variation was observed in the chicken carcass rinse matrix. In order to evaluate this variation, twelve Campylobacter-free chickens of mixed origin were purchased from local retailers. They were rinsed as described, and the rinse was inoculated with ten-fold dilutions ranging from $1 \times 10^{2}$ to $1 \times 10^{6} \mathrm{CFU} / \mathrm{ml} \mathrm{C}$. jejuni and C. coli, respectively, and subsequent DNA extraction and Q-PCR was performed.

Variation attributable to the individual species: The Q-PCR assay described in this study amplifies the three foodborne species of Campylobacter: $C$. jejuni, $C$. coli and $C$. lari. In order to quantify all species simultaneously, without further differentiation, equal sensitivity and amplification efficiency $(A E)$ for all species had to be assumed. To test this hypothesis, standard dilution series 
made from both pure DNA and bacterial cells of the three species were investigated by Q-PCR analysis.

The DNA concentration of the following strains: C. jejuni CCUG 12795 and 14539, C. coli CCUG 10951 and 12791 and C. lari CCUG 20707 and 23947 was adjusted to $1 \mathrm{ng} / \mu$ l based on measurements performed on a NanoDrop (Thermo Scientific, Waltham, MA), and ten-fold serial dilutions were prepared and analysed in duplicate by Q-PCR (100 fg-10 ng/PCR).

Campylobacter jejuni CCUG 11284, C. coli CCUG 11283 and C. lari CCUG 23947 were recovered on five blood agar plates each. For each species, the growth was transferred to approx. $10 \mathrm{ml}$ of physiological saline, and the suspension was mixed thoroughly to ensure a homogenous suspension of bacterial cells. A ten-fold serial dilution was prepared for each species ranging from $10^{-1}$ to $10^{-9}$. The numbers of bacterial cells in the suspensions were determined by duplicate plate spreading on blood agar. Standard rows ranging from 1 to $1 \times 10^{6} \mathrm{CFU} / \mathrm{ml}$ were produced from the three species. To improve the linearity of the standard curves a background of $10^{8}$ to $10^{9} \mathrm{CFU} / \mathrm{ml}$ Escherichia coli ATTC 25922 was added to the standards. One $\mathrm{ml}$ volumes were drawn from the standards, DNA was extracted as described and they were analysed in duplicate by Q-PCR. This procedure was repeated with two biological replicates, four times for $C$. jejuni, and two times for C. coli and C. lari, to observe the variation between different bacterial suspensions and dilution series.

Quantification of live Campylobacter in naturally infected Danish chickens post slaughter: The number of Campylobacter on fifty chickens from a confirmed Campylobacter-positive flock was quantified in parallel by Q-PCR (with and without PMA sample treatment) and conventional culture. The chickens were collected immediately after cooling at the abattoir, packed in sterile plastic bags, and kept at $5^{\circ} \mathrm{C}$ until analysed $(<18 \mathrm{~h})$. The chickens were rinsed as described. Duplicate chicken carcass rinse volumes, with and without PMA treatment prior to DNA extraction, were analysed by Q-PCR in duplicate as described. From parallel duplicate chicken carcass rinse volumes, ten-fold serial dilutions ranging from $10^{\circ}$ to $10^{-2}$ were prepared and the number of Campylobacter was determined in duplicate by culture as described.

\section{Bacterial strains and culture conditions}

Campylobacter strains were stored at $-80^{\circ} \mathrm{C}$ in $\mathrm{LB}$ medium containing $15 \%$ glycerol as cryoprotectant (Statens Serum Institute, SSI, Copenhagen, Denmark). They were recovered on blood agar (SSI) and isolated on selective solid medium; modified charcoal cefoperazone deoxycholate agar (mCCDA, Oxoid, Greve, Denmark) and Abeyta-Hunt-Bark agar (AHB, Technical 
University of Denmark, DTU, Copenhagen, Denmark). Mueller-Hinton broth (SSI) was used to produce overnight cultures for preparing the quantification standards, and for artificial inoculation of chicken carcass rinse. Incubation was at all times performed at $41.5 \pm 1^{\circ} \mathrm{C}$ under microaerobic conditions $\left(6 \% \mathrm{O}_{2}, 7 \% \mathrm{CO}_{2}, 7 \% \mathrm{H}_{2}\right.$ and $\left.80 \% \mathrm{~N}_{2}\right)$.

\section{Chicken carcass rinse}

Chicken carcass rinse was prepared according to the recommendations in ISO 6887-2 (6). A whole fresh chicken was placed in a sterile plastic bag and rinsed manually in $50 \mathrm{ml}$ of physiological saline $(0.9 \% \mathrm{NaCl})$ for $1 \mathrm{~min}$. One $\mathrm{ml}$ aliquots were drawn for DNA extraction and subsequent Q-PCR analysis, and for culture.

\section{Culture-based enumeration}

From the chicken carcass rinse duplicate ten-fold serial dilutions ranging from $10^{\circ}$ to $10^{-2}$ were prepared and $100 \mu \mathrm{l}$ of each dilution was spread onto mCCDA and AHB and incubated for $48 \mathrm{~h}$. The agar plates were dried for $30 \mathrm{~min}$ prior to use, to avoid swarming of the colonies. Two selective agar plates were applied according to the recommendations of ISO 10272-1. Five presumptive Campylobacter colonies pr. chicken carcass rinse were verified by colony-PCR (20), by dissolving a minimal amount of colony material in $100 \mu \mathrm{l}$ of physiological saline and analyzing $10 \mu \mathrm{l}$ of this suspension in Q-PCR, with 10 min of primary denaturation to ensure cell wall disruption and DNA accessibility.

\section{Propidium monoazide treatment of samples}

Preliminary experiments and literature reviews were performed to determine the concentration of PMA, time of incubation and light exposure, and distance from light source. Propidium monoazide (PMA, Biotium Inc., Hayward, CA) dissolved in 20\% dimethyl sulfoxide (DMSO, Sigma-Aldrich, Brøndby, Denmark) was added to $1 \mathrm{ml}$ volumes of chicken carcass rinse to a final concentration of $10 \mu \mathrm{g} / \mathrm{ml}$. The chicken carcass rinse added PMA was incubated in clear Eppendorf tubes in the dark for $5 \mathrm{~min}$, and inverted repeatedly twice during this period. Following incubation the Eppendorf tubes were placed on ice and exposed to a $650 \mathrm{~W}$ halogen light source (Kaiser Videolight 6, Kaiser Fototechnik, Buchen, Germany), with a distance of $20 \mathrm{~cm}$, for $1 \mathrm{~min}$. The Eppendorf tubes were swirled shortly by hand every $15 \mathrm{sec}$, and turned over after $30 \mathrm{sec}$ of illumination, to ensure complete cross linking of available DNA, and conversion of free PMA to hydroxylamino propidium. 


\section{DNA extraction}

One $\mathrm{ml}$ volumes of chicken carcass rinse/standard were centrifuged at $3000 \times \mathrm{g}$ for $5 \mathrm{~min}$ at $4^{\circ} \mathrm{C}$, and DNA-extraction performed on a KingFisher (Thermo Labsystems, Helsinki, Finland) using a DNA isolation kit for blood, stool, cells and tissue (Magnesil KF, Genomic system, Promega) as specified by the manufacturer. Briefly, the sample pellet was re-suspended in $200 \mu$ lysis buffer and transferred to wells $A, B$ and $C$ of a 96-well plate (Thermo Labsystems) containing paramagnetic particles ( $90 \mu$ divided into wells A, B and C), salt washing buffer ( $200 \mu$ ldivided into wells $D$ and $E$ ), alcohol wash ( $200 \mu$ l divided into wells $F$ and $G$ ) and $100 \mu$ l of elution buffer (well $\mathrm{H}$ ), and the DNA extraction program (Genomic_DNA_1) was performed. Ten $\mu$ of the extracted DNA was used as template in the Q-PCR. In every 96-well plate (corresponding to 12 DNA extractions) a process control consisting of only DNA extraction reagents was included.

\section{Q-PCR analysis}

A 5' nuclease Q-PCR method for the specific detection of foodborne thermotolerant Campylobacter was performed on an Mx3005P (Stratagene, La Jolla, CA), as described previously (16) with the following modifications: $0.6 \mathrm{mM}$ deoxynucleoside triphosphate mixture (Applied Biosystems, Naerum, Denmark), $0.5 \mu \mathrm{M}$ forward and reverse primer, $0.2 \mathrm{~g} / \mathrm{L}$ bovine serum albumin (BSA, Roche A/S), $0.8 \mathrm{ml} / \mathrm{L}$ glycerol (87\%, Merck, Darmstadt, Germany), $75 \mathrm{nM}$ target locked nucleic acid (LNA) Campylobacter probe 5' [6FAM] CA[+T] CC[+T] CCA CGC GGC G[+T]T GC [BHQ1] 3' (Sigma-Aldrich), $60 \mathrm{nM}$ internal amplification control (IAC) probe, and $10 \mu \mathrm{l}$ of extracted template DNA. The cycle profile was as follows: initial denaturation at $95^{\circ} \mathrm{C}$ for $3 \mathrm{~min}(10 \mathrm{~min}$ for colony-PCR), followed by 40 cycles of $95^{\circ} \mathrm{C}$ for $15 \mathrm{~s}, 60^{\circ} \mathrm{C}$ for $60 \mathrm{~s}$ and $72^{\circ} \mathrm{C}$ for $30 \mathrm{~s}$. Fluorescence measurements were obtained online and analyzed with the MxPro-Mx3005P software (version 3.00). The threshold was assigned using the software option: background-based threshold, i.e. the standard deviation of all amplifications was determined from cycle 5 to 9 (or a similar appropriate interval), and this value was multiplied by a background sigma multiplier of 10 .

In every Q-PCR analysis the $C$. jejuni standard for absolute quantification was included in duplicate. Furthermore, a non-template control (NTC) containing PCR grade water, a negative DNA control (5 ng of Escherichia coli DNA) and a positive DNA control (5 ng of Campylobacter jejuni DNA) were included. 


\section{Standard curve for absolute quantification}

Campylobacter jejuni CCUG 11284 was recovered on blood agar (SSI). A loop full of colony material was transferred to $10 \mathrm{ml}$ of Mueller-Hinton broth and incubated for approx. 16 hours. From this suspension a ten-fold serial dilution was prepared and enumerated by plate spreading onto blood agar in triplicate. One $\mathrm{ml}$ volumes of Campylobacter-free chicken carcass rinse were inoculated with $1 \times 10^{2}$ to $1 \times 10^{7}$ CFU C. jejuni CCUG 11284 from the appropriate dilution, and the DNA extracted from these as described above. Three biological and six Q-PCR replicates was used to produce the standard curve.

\section{Data analysis}

Variation attributable to matrix and species: The variation between the standard curves produced in these experiments was evaluated by linear regression (Microsoft ${ }^{\circledR}$ Excel 2000). For each standard curve, $\mathrm{CFU} / \mathrm{ml}$ or DNA concentration was $\log _{10}$-transformed and defined as the independent variable. The $\mathrm{Ct}$ - or $\Delta \mathrm{Ct}$-value was defined as the dependent variable. The $95 \%$ confidence intervals of estimates of slope and intercept, respectively, were used for the comparison of standard curves. Standard curves with overlapping $95 \%$ confidence intervals were not regarded as statistically significantly different.

Standard curve: The standard curve was produced by plotting the Ct-value obtained in Q-PCR against the number of CFU in the standards. From this linear relationship the AE was calculated from: $A E=10^{-1 / \text { slope }}-1$ (19).

Quantification of live Campylobacter in Danish chickens post slaughter: The correlation between the results obtained by Q-PCR (with and without PMA-treatment) and the culture-based enumeration was evaluated by plotting the $\log _{10}$-transformed Campylobacter cell equivalents (CCE)/ml obtained from the Q-PCR against the $\log _{10}$-transformed CFU/ml obtained by duplicate plate spreading on mCCDA. For comparison of the ability of Q-PCR (with and without PMA) to predict CFU counted on mCCDA, the difference between the $\log _{10}$-transformed bacterial numbers was used as response variable in a single factor analysis of variance (Microsoft ${ }^{\circledR}$ Excel 2000), comparing Q-PCR with PMA to Q-PCR without PMA. A P-value below 0.05 was considered statistically significant. 


\section{Results}

Preliminary optimization and investigation of the quantitative aspect: Preliminary experiments were performed to optimize the volume applied for rinsing of chicken carcasses, the volume to draw from the chicken carcass rinse for DNA extraction and the DNA template volume for Q-PCR. Optimal method performance was obtained when a rinse volume of $50 \mathrm{ml}$, a sampling volume of 1 $\mathrm{ml}$, and a DNA template volume of $10 \mu \mathrm{l}$ was applied (data not shown). Furthermore, it was not possible to obtain good detection without the DNA extraction step.

Experiments to evaluate the recovery of Campylobacter in the $50 \mathrm{ml}$ rinsing procedure were performed. On naturally infected chicken carcasses, the second rinsing procedure yielded approx. $60 \%$ of the initial amount of Campylobacter than the initial rinsing. Performing two subsequent rinsing procedures $45 \%$, and $27 \%$ of the initial amount of Campylobacter were recovered. The recovery of Campylobacter from artificially inoculated chicken carcasses ranged from 55 to $94 \%$ and was determined to be $77 \%$ in average.

Variation attributable to the matrix and individual species: The variation attributable to the chicken carcass rinse matrix was evaluated from twelve standard curves of $C$. jejuni and $C$. coli in different chicken carcass rinse matrices. As shown in Figure 1, the contribution to variation from the chicken carcass rinse matrix was negligible, as no statistical significant difference $(P>0.05)$ was found.

The variation attributable to the individual Campylobacter species was evaluated from standard curves of both pure DNA and bacterial cells. Standard curves produced by dilution of DNA from six individual strains were constructed (Figure 2), and it was found that the variation between species was statistically insignificant $(P>0.05)$. Standard curves for cells were obtained by subtracting the Ct-value for each dilution from the Ct-value obtained for the highest number of cell input (Figure 3). Delta Ct-values were applied to describe the variation between the three species on cell level since the input cell number was difficult to accurately standardize, and this could obscure the true variation, Similarly to the DNA, the variance between the three species was not significant $(P>$ 0.05 ) on the cell level, proving equal sensitivity and amplification efficiency of the method independent of species.

Standard curve for absolute quantification using Q-PCR: The standard curve, produced from DNA extracted from 10-fold cell dilutions in chicken carcass rinse, applied for absolute quantification of Campylobacter in the naturally infected chicken carcass rinse showed an AE of 91\%, computed from the slope of the linear relationship between the $\log _{10}$-transformed $\mathrm{CFU} / \mathrm{ml}$ and the Ct-value 
$\left(R^{2}=0.993\right)$. The method was shown to be linear in the range of $1 \times 10^{2}$ to $1 \times 10^{7} \mathrm{CFU} / \mathrm{ml}$ chicken carcass rinse, and the limit of quantification thereby $1 \times 10^{2} \mathrm{CFU} / \mathrm{ml}$. Taking into consideration the volume reduction during DNA extraction, this corresponds to $10 \mathrm{CFU} / \mathrm{PCR}$. From the standard curve, the level of Campylobacter was expressed by the equation: $\mathrm{Ct}=-3.571 \times \log (\mathrm{CFU})+40.8$.

Evaluation of variation in culture based enumeration: Two parallel dilutions of chicken carcass rinse was plate spread onto selective agar (mCCDA and AHB), to evaluate the contribution of the culture enumeration to the overall variation of the method. The linear relationship between the replicate culture series was expressed by the equations: $y=1.0004 x$ for $m C C D A\left(R^{2}=0.9693\right)$ and $y$ $=1.0154 x$ for $A H B\left(R^{2}=0.9351\right)$, indicating an extremely low variation in the quantitative results obtained by culture.

Quantification of live Campylobacter in naturally infected Danish chickens post slaughter: The number of Campylobacter on fifty chickens post slaughter from a confirmed Campylobacterpositive flock was quantified in parallel by Q-PCR (with and without PMA sample treatment) and conventional culture (Table 1). By culture, 42 chickens were found Campylobacter-positive, while this number was 45 for Q-PCR with PMA-treatment, and 48 without PMA-treatment. The culturenegative/Q-PCR-positive chickens had low levels of Campylobacter, below the quantification limit of the Q-PCR. The same applied for chickens found Campylobacter-positive by Q-PCR without PMA-treatment, but Campylobacter-negative with PMA-treatment. The infection level of the Campylobacter-positive chicken carcass rinses ranged from 25 to $1.5 \times 10^{6} \mathrm{CFU} / \mathrm{ml}$, reflecting the difference in contamination in a flock.

The correlation between the results obtained by Q-PCR (with and without PMA-treatment) and the culture-based enumeration was evaluated. Except for chicken no. 2 and 7, where the CCE/ml were approximately the same with and without PMA-treatment, the PMA-treated samples gave a reduced signal in Q-PCR. A reduction-range of $1 \times 10^{2}$ to $2.4 \times 10^{6} \mathrm{CCE} / \mathrm{ml}$ was observed in PMAtreated samples, and the reduction was positively correlated to the amount of Campylobacter in the samples. This is also reflected in the obvious linear correlation between the Q-PCR results obtained from both PMA-treated and -untreated samples and the enumeration by culture (Figure 4). The data analysis of the culture-based enumeration was based on the average obtained from the duplicate mCCDA plates, since a better correlation was obtained by these, than the AHB plates. Analysis of variance comparing Q-PCR (with and without PMA) to plate counts on mCCDA, showed that Q-PCR with PMA-treatment produced results that were statistically significantly closer to counts on mCCDA $(P<0.001)$. 


\section{Discussion}

As many advantages as the Q-PCR technology offers regarding pathogen detection in mixed populations, a major drawback has been that PCR detection, operating on DNA level, cannot distinguish between DNA arising from viable and dead bacterial cells. This has been one of the main causes hindering the implementation of PCR in routine diagnostics for food, where quantification of viable bacteria is essential in relation to risk assessment. It is a serious limitation of the PCR technology which is of particular relevance for Campylobacter, since mitigation strategies are focusing increasingly on post-slaughter decontamination, leaving the PCR technology unable to assess the potential for foodborne infections. In 2006, EC Regulation (No. 853/2004) permitted the use of other substances than water for decontamination of meat surfaces (5). Both physical and chemical reduction strategies, including treatment with steam, ultraviolet light, high hydrostatic pressure, essential oil fractions, acid and sodium hypochlorite, have been investigated for their Campylobacter reduction potential, with varying outcome $(1,7,8$, $11,14,21,25,29,31)$. DNA from dead bacterial cells has been shown to persist for up to three weeks following cell death (18), and it has also been demonstrated that the presence of DNA from dead Campylobacter cells can lead to an overestimation of the number of viable cells, and in some instances, even to false positive responses (37).

In the present study a novel technique to distinguish between viable and dead cells by PMA-PCR $(27,28,35)$, was applied successfully to diagnostic quantification of viable Campylobacter in naturally contaminated chicken carcass rinse. PMA-PCR is claimed to detect "viable" cells. However, "viable" can be defined in several ways: as having an intact membrane, the ability to metabolise compounds and/or the ability to withhold a proton gradient between the inner and outer part of the cell. To further distinguish between these states the PMA-PCR method can be supplemented with other compounds, e.g. to show the presence of an intact metabolism (27). Despite this uncertainty, the PMA-PCR quantification compared favourably to direct culture-based detection of Campylobacter in this study. The relative specificity of the PMA-PCR method was $100 \%$, and it was shown to be more sensitive than the culture-based method. Three chicken carcass rinse samples were found positive by PMA-PCR but not by culture. According to ISO 20838:2006 these can be regarded as true positives due to the target specific DNA-probe based PCR-response (4). Besides being labour-intensive and time-consuming, culture-based quantification will not detect the VBNC fraction of a given Campylobacter population. The results obtained in the present study, suggest that VBNC Campylobacter were not present in great numbers on the chicken carcasses sampled immediately post slaughter. However, the ratio between viable and VBNC cells can only be expected to decrease as a consequence of food processing and storage, thus presenting a possible diagnostic uncertainty. Furthermore, post 
slaughter mitigation strategies to reduce viable Campylobacter on chicken carcasses, will most certainly contribute to the number of VBNC cells. As long as the infectious potential of the Campylobacter VBNC state is not clarified, quantitative methods for risk assessment should detect these as well.

The good correlation demonstrated in this study between the counts obtained by Q-PCR with PMA-treatment and culture, enables calculation of the amount of Campylobacter in naturally infected chicken carcass rinse from a Ct-value obtained by Q-PCR. It has been demonstrated in several studies, comparing Q-PCR to culture-based enumeration, that higher counts are produced by Q-PCR, which have been explained by the detection of DNA from dead and VBNC cells $(9,13$, 39). In the present study this was also true for the PMA-untreated samples, however when the PMA-treatment was applied a lower Q-PCR count than culture-based count was often observed. The reason for this could partly be due to underestimation of the cell input in the standard applied for quantification, but also due to overestimation of the number of Campylobacter colonies on the mCCDA plates. Five presumptive Campylobacter colonies from each chicken carcass rinse were sub-cultured to non-selective medium and subsequently verified by colony-PCR. The results indicated that not all Campylobacter-like colonies on the mCCDA plates could in fact be confirmed as being $C$. jejuni, $C$. coli or $C$. lari, substantiating this theory (data not shown). Another issue that has to be considered in this regard is that the cell state, and permeability of the cell wall, is not a clear cut reflection of a viable or dead cell, and PMA could have entered a minor fraction of culturable cells.

The quantification limit of the present PMA-PCR method was $100 \mathrm{CFU} / \mathrm{ml}$ chicken carcass rinse, not meeting the legislative demands of detection of $1 \mathrm{CFU} / 25 \mathrm{~g}$ (3). Available technologies do, however, not enable separation and concentration of the target organism from the food matrix, resulting in the necessity of a certain level of Campylobacter before direct detection by Q-PCR (and culture) is possible. The results from the preliminary rinsing experiments also showed that the low rinsing volume of $50 \mathrm{ml}$, did far from recover all the Campylobacter cells present on the chicken carcasses. The rinsing of artificially infected chickens resulted in an average recovery of $77 \%$, but despite droplet inoculation and time for attachment to simulate natural infection, it is likely that recovery would be lower from natural infected chickens. A rinsing volume of $310 \mathrm{ml}$ was applied in a study by Jørgensen et al. (2002), yet similar recovery rates to the present study were observed; 49 and $25 \%$ of the yield from the primary rinse was found in the second and third rinsing procedure (15). This has to be considered in estimating the whole carcass contamination level when employing the PMA-PCR method for enumeration of naturally contaminated chicken carcasses. Immunocapture of Campylobacter prior to PCR, reducing sample volumes from $250 \mathrm{ml}$ to only $200 \mu \mathrm{l}$, have been conducted, but showed poor recovery rates (24). Wolffs et al. (2005) 
described the use of flotation to single out viable and VBNC Campylobacter prior to Q-PCR. The limit of detection of this flotation-based method was determined to be $8.6 \times 10^{2} \mathrm{CFU} / \mathrm{ml}$ and quantification was possible in the range of $2.6 \times 10^{3}$ to $2.6 \times 10^{7} \mathrm{CFU} / \mathrm{ml}$ in chicken carcass rinse (38).

Despite not meeting the legislative detection demands, direct Q-PCR methods for Campylobacter are applicable as tools for risk assessment and assurance of food safety, since it has been shown that a strong positive correlation exists between the number of Campylobacter on chickens, and the risk of human infections $(23,34,36)$. It would likewise be feasible that the risk of cross contamination is proportional to the number of Campylobacter cells present on the chicken carcass.

In contrast to other Q-PCR methods for Campylobacter, the assay applied in this study has been validated in comparative and collaborative trials according to the recommendations of the Nordic Organisation for Validation of Alternative Microbiological Methods (NordVal) (2) and approved for detection of Campylobacter in chicken, cloacae swabs and boot swabs (20). The inclusivity and exclusivity of the primers has been determined on 115 target and 87 non-target strains to 100 and $97 \%$, respectively (22). The amplification efficiency, linear range, detection probability and detection precision of the assay has been evaluated and its suitability for quantitative PCR analysis confirmed (16). It includes in an internal amplification control to avoid false negative responses and reveal PCR inhibition. Finally, the standard dilution series for calculation of the level of Campylobacter was produced from ten-fold cell dilutions (not DNA) in the relevant matrix, from which DNA was subsequently extracted and analysed in Q-PCR, taking into account that efficiency of DNA extraction can vary substantially with initial amount of cells (17).

In conclusion, this study presents a diagnostic tool for quantitative detection of foodborne viable Campylobacter, that can be applied to produce accurate and reliable data for risk assessments in chicken carcass rinse. The Q-PCR-method is ready to be applied in industry and control laboratories, not detecting DNA from dead Campylobacter, but recognising the infectious potential of the VBNC state, and thereby able to assess the outcome and impact of new mitigation strategies. 


\section{Acknowledgements}

The work was supported in part by the European Union-funded Integrated Project BIOTRACER (Contract 036272) under the $6^{\text {th }}$ RTD Framework. The authors thank Liselotte Folling for excellent technical assistance and proofreading of the experimental plans and Lantmännen Danpo for kindly providing the samples and for sampling assistance. Jeffrey Skiby is acknowledged for critical reading of the manuscript. 


\section{References}

1. Anderson, R. C., R. B. Harvey, J. A. Byrd, T. R. Callaway, K. J. Genovese, T. S. Edrington, Y. S. Jung, J. L. McReynolds, and D. J. Nisbet. 2005. Novel preharvest strategies involving the use of experimental chlorate preparations and nitro-based compounds to prevent colonization of foodproducing animals by foodborne pathogens. Poult. Sci. 84:649-654.

2. Anonymous. 2009. Protocol for the validation of alternative microbiological methods. Nordic Committee on Food Analysis (NMKL), NordVal, Oslo, Norway.

3. Anonymous. 2006. Microbiology of food and animal feeding stuffs - Horizontal method for detection and enumeration of Campylobacter spp. Part 1: Detection method ISO 10272. International Standard Organization (ISO), Geneva, Switzerland.

4. Anonymous. 2006. Microbiology of food and animal feeding stuffs - Polymerase chain reaction (PCR) for the detection of food borne pathogens - requirements for amplification and detection for qualitative methods ISO 20838. International Standard Organisation (ISO), Geneva, Switzerland.

5. Anonymous. 2004. Regulation (EC) No. 853/2004 of the European parliament and of the council of 29 April 2004 laying down specific hygiene rules for food of animal origin. Official Journal of the European Union 22-82.

6. Anonymous. 2000. Microbiology of food and animal feeding stuffs. Preparation of test samples, initial suspension and decimal dilution for microbiological examination. Part 2. Specific rules for the preparation of the initial suspension and decimal dilutions of meat and meat products ISO/CD 6887-2. International Standard Organisation (ISO), AFNOR, Paris, France.

7. Bauermeister, L. J., J. W. Bowers, J. C. Townsend, and S. R. McKee. 2008. Validating the efficacy of peracetic acid mixture as an antimicrobial in poultry chillers. J. Food Prot. 71:11191122.

8. Bieche, C., M. Ritz, O. Tresse, M. Federighi, and M. de Lamballerie. 2009. Impacts of treatment parameters on the inactivation of Campylobacter jejuni by high pressure: a statistical study of main effects and interactions. Lett. Appl. Microbiol. 48:198-202.

9. Botteldoorn, N., E. Van Coillie, V. Piessens, G. Rasschaert, L. Debruyne, M. Heyndrickx, L. Herman, and W. Messens. 2008. Quantification of Campylobacter spp. in chicken carcass rinse by real-time PCR. J. Appl. Microbiol. 105:1909-1918.

10. Debretsion, A., T. Habtemariam, S. Wilson, D. Nganwa, and T. Yehualaeshet. 2007. Real-time PCR assay for rapid detection and quantification of Campylobacter jejuni on chicken rinses from poultry processing plant. Mol. Cell. Probes 21:177-181. 
11. Fisher, K. and C. A. Phillips. 2006. The effect of lemon, orange and bergamot essential oils and their components on the survival of Campylobacter jejuni, Escherichia coli 0157, Listeria monocytogenes, Bacillus cereus and Staphylococcus aureus in vitro and in food systems. J. Appl. Microbiol. 101:1232-1240.

12. Fitzgerald, C., J. Whichard, and I. Nachamkin. 2008. Diagnosis and antimicrobial susceptability of Campylobacter species, p. 227-243. In I. Nachamkin, C. M. Szymanski and M. J. Blaser (ed.), Campylobacter. ASM Press, Washington DC.

13. Hong, J., Woo Kyung Jung, Jun Man Kim, So Hyun Kim, Hye Cheong Koo, J. Ser, and Y. H. Park. 2007. Quantification and differentiation of Campylobacter jejuni and Campylobacter coli in raw chicken meats using a real-time PCR method. J. Food Prot. 70:2015-2022.

14. Isohanni, P. M. and U. Lyhs. 2009. Use of ultraviolet irradiation to reduce Campylobacter jejuni on broiler meat. Poult. Sci. 88:661-668.

15. Jørgensen, F., R. Bailey, S. Williams, P. Henderson, D. R. Wareing, F. J. Bolton, J. A. Frost, L. Ward, and T. J. Humphrey. 2002. Prevalence and numbers of Salmonella and Campylobacter spp. on raw, whole chickens in relation to sampling methods. Int. J. Food Microbiol. 76:151-164.

16. Josefsen, M. H., N. R. Jacobsen, and J. Hoorfar. 2004. Enrichment followed by quantitative PCR both for rapid detection and as a tool for quantitative risk assessment of food-borne thermotolerant campylobacters. Appl. Environ. Microbiol. 70:3588-3592.

17. Josefsen, M. H., M. Krause, F. Hansen, and J. Hoorfar. 2007. Optimization of a 12-hour TaqMan PCR-based method for detection of Salmonella bacteria in meat. Appl. Environ. Microbiol. 73:3040-3048.

18. Josephson, K. L., C. P. Gerba, and I. L. Pepper. 1993. Polymerase chain reaction detection of nonviable bacterial pathogens. Appl. Environ. Microbiol. 59:3513-3515.

19. Klein, D., P. Janda, R. Steinborn, M. Muller, B. Salmons, and W. H. Gunzburg. 1999. Proviral load determination of different feline immunodeficiency virus isolates using real-time polymerase chain reaction: influence of mismatches on quantification. Electrophoresis 20:291-299.

20. Krause, M., M. H. Josefsen, M. Lund, N. R. Jacobsen, L. Brorsen, M. Moos, A. Stockmarr, and J. Hoorfar. 2006. Comparative, collaborative, and on-site validation of a TaqMan PCR method as a tool for certified production of fresh, Campylobacter-free chickens. Appl. Environ. Microbiol. 72:5463-5468.

21. Li, Y., H. Yang, and B. L. Swem. 2002. Effect of high-temperature inside-outside spray on survival of Campylobacter jejuni attached to prechill chicken carcasses. Poult. Sci. 81:1371-1377.

22. Lubeck, P. S., P. Wolffs, S. L. On, P. Ahrens, P. Radstrom, and J. Hoorfar. 2003. Toward an international standard for PCR-based detection of food-borne thermotolerant Campylobacters: assay development and analytical validation. Appl. Environ. Microbiol. 69:5664-5669. 
23. Messens, W., E. Hartnett, X. Gellynck, J. Viaene, D. Halet, L. Herman, and K. Grijspeerdt. 2007. Quantitative risk assessment of human campylobacteriosis through the consumption of chicken meat in Belgium. XVIII European symposium on the quality of poultry meat and XII European symposium on the quality of eggs and egg products. p. 167-168.

24. Morales-Rayas, R., P. F. Wolffs, and M. W. Griffiths. 2008. Immunocapture and real-time PCR to detect Campylobacter spp. J. Food Prot. 71:2543-2547.

25. Nannapaneni, R., V. I. Chalova, P. G. Crandall, S. C. Ricke, M. G. Johnson, and C. A. O'Bryan. 2009. Campylobacter and Arcobacter species sensitivity to commercial orange oil fractions. Int. J. Food Microbiol. 129:43-49.

26. Nebe-von-Caron, G., P. J. Stephens, C. J. Hewitt, J. R. Powell, and R. A. Badley. 2000. Analysis of bacterial function by multi-colour fluorescence flow cytometry and single cell sorting. J. Microbiol. Methods 42:97-114.

27. Nocker, A., C. Y. Cheung, and A. K. Camper. 2006. Comparison of propidium monoazide with ethidium monoazide for differentiation of live vs. dead bacteria by selective removal of DNA from dead cells. J. Microbiol. Methods 67:310-320.

28. Nogva, H. K., S. M. Dromtorp, H. Nissen, and K. Rudi. 2003. Ethidium monoazide for DNAbased differentiation of viable and dead bacteria by 5'-nuclease PCR. BioTechniques 34:804-8, 810, 812-3.

29. Northcutt, J., D. Smith, K. D. Ingram, A. Hinton Jr, and M. Musgrove. 2007. Recovery of bacteria from broiler carcasses after spray washing with acidified electrolyzed water or sodium hypochlorite solutions. Poult. Sci. 86:2239-2244.

30. Olson, K. C., S. Ethelberg, W. Van Pelt, and V. Tauxe. 2008. Epidemiology of Campylobacter jejuni infections in industrialized nations, p. 163-189. In I. Nachamkin, C. M. Szymanski and M. J. Blaser (ed.), Campylobacter. ASM Press, Washington DC.

31. Oyarzabal, O. A., C. Hawk, S. F. Bilgili, C. C. Warf, and G. K. Kemp. 2004. Effects of postchill application of acidified sodium chlorite to control Campylobacter spp. and Escherichia coli on commercial broiler carcasses. J. Food Prot. 67:2288-2291.

32. Rollins, D. M. and R. R. Colwell. 1986. Viable but nonculturable stage of Campylobacter jejuni and its role in survival in the natural aquatic environment. Appl. Environ. Microbiol. 52:531-538.

33. Rönner, A. C. and H. Lindmark. 2007. Quantitative detection of Campylobacter jejuni on fresh chicken carcasses by real-time PCR. J. Food Prot. 70:1373-1378.

34. Rosenquist, H., N. L. Nielsen, H. M. Sommer, B. Norrung, and B. B. Christensen. 2003. Quantitative risk assessment of human campylobacteriosis associated with thermophilic Campylobacter species in chickens. Int. J. Food Microbiol. 83:87-103. 
35. Rudi, K., B. Moen, S. M. Dromtorp, and A. L. Holck. 2005. Use of ethidium monoazide and PCR in combination for quantification of viable and dead cells in complex samples. Appl. Environ. Microbiol. 71:1018-1024.

36. Stern, N. J. and S. Pretanik. 2006. Counts of Campylobacter spp. on U.S. broiler carcasses. J. Food Prot. 69:1034-1039.

37. Wolffs, P., B. Norling, and P. Radstrom. 2005. Risk assessment of false-positive quantitative real-time PCR results in food, due to detection of DNA originating from dead cells. J. Microbiol. Methods 60:315-323.

38. Wolffs, P., B. Norling, J. Hoorfar, M. Griffiths, and P. Radstrom. 2005. Quantification of Campylobacter spp. in chicken rinse samples by using flotation prior to real-time PCR. Appl. Environ. Microbiol. 71:5759-5764.

39. Yang, C., Y. Jiang, K. Huang, C. Zhu, and Y. Yin. 2003. Application of real-time PCR for quantitative detection of Campylobacter jejuni in poultry, milk and environmental water. FEMS Imm. Med. Microbiol. 38:265-271. 
Table 1. Results obtained from Q-PCR (with and without PMA-treatment) and culture-based quantification of Campylobacter in naturally infected chicken carcass rinse.

\begin{tabular}{|c|c|c|c|c|c|c|}
\hline \multirow[b]{3}{*}{ Chicken no. } & \multicolumn{5}{|c|}{ Q-PCR } & \multirow{3}{*}{$\begin{array}{l}\text { Culture } \\
\text { CFU/ml }\end{array}$} \\
\hline & \multicolumn{2}{|c|}{ Ct-value Campylobacter } & \multicolumn{3}{|c|}{ CCE Campylobacter/ml } & \\
\hline & w/ PMA & wo/ PMA & w/ PMA & wo/ PMA & Wo/ PMA-w/ PMA & \\
\hline 1 & 35.1 & 34.8 & + & + & + & $4.00 \times 10^{1}$ \\
\hline 2 & 28.8 & 31.0 & $8.44 \times 10^{2}$ & $4.08 \times 10^{2}$ & $-4.36 \times 10^{2}$ & $2.55 \times 10^{2}$ \\
\hline 3 & 30.5 & 30.1 & $2.70 \times 10^{2}$ & $3.75 \times 10^{2}$ & $1.05 \times 10^{2}$ & $3.90 \times 10^{2}$ \\
\hline 4 & 21.6 & 22.1 & $1.20 \times 10^{5}$ & $1.94 \times 10^{5}$ & $7.42 \times 10^{4}$ & $1.17 \times 10^{5}$ \\
\hline 5 & 30.7 & 31.9 & $2.26 \times 10^{2}$ & + & + & $3.85 \times 10^{2}$ \\
\hline 6 & 28.1 & 28.4 & $1.39 \times 10^{3}$ & $2.67 \times 10^{3}$ & $1.28 \times 10^{3}$ & $1.90 \times 10^{3}$ \\
\hline 7 & 25.8 & 27.1 & $6.68 \times 10^{3}$ & $6.52 \times 10^{3}$ & $-1.57 \times 10^{2}$ & $3.20 \times 10^{3}$ \\
\hline 8 & 30.7 & 29.3 & $2.48 \times 10^{2}$ & $1.33 \times 10^{3}$ & $1.08 \times 10^{3}$ & $1.13 \times 10^{3}$ \\
\hline 9 & 28.6 & 28.2 & $1.01 \times 10^{3}$ & $2.56 \times 10^{3}$ & $1.55 \times 10^{3}$ & $1.72 \times 10^{3}$ \\
\hline 10 & 28.1 & 27.4 & $1.48 \times 10^{3}$ & $4.68 \times 10^{3}$ & $3.21 \times 10^{3}$ & $2.10 \times 10^{3}$ \\
\hline 11 & 29.7 & 28.7 & $4.87 \times 10^{2}$ & $1.88 \times 10^{3}$ & $1.39 \times 10^{3}$ & Swarming \\
\hline 12 & 21.1 & 20.2 & $1.74 \times 10^{5}$ & $6.56 \times 10^{5}$ & $4.81 \times 10^{5}$ & $2.07 \times 10^{5}$ \\
\hline 13 & 28.5 & 28.1 & $1.11 \times 10^{3}$ & $2.95 \times 10^{3}$ & $1.84 \times 10^{3}$ & $7.30 \times 10^{2}$ \\
\hline 14 & 30.0 & 28.2 & $3.96 \times 10^{2}$ & $2.59 \times 10^{3}$ & $2.19 \times 10^{3}$ & $1.00 \times 10^{3}$ \\
\hline 15 & 27.3 & 25.5 & $3.33 \times 10^{3}$ & $1.67 \times 10^{4}$ & $1.33 \times 10^{4}$ & $2.90 \times 10^{3}$ \\
\hline 16 & 29.3 & 27.8 & $6.29 \times 10^{2}$ & $4.20 \times 10^{3}$ & $3.57 \times 10^{3}$ & $8.20 \times 10^{2}$ \\
\hline 17 & 31.0 & 28.8 & $2.02 \times 10^{2}$ & $1.81 \times 10^{3}$ & $1.61 \times 10^{3}$ & $3.00 \times 10^{2}$ \\
\hline 18 & 28.0 & 26.0 & $1.48 \times 10^{3}$ & $1.14 \times 10^{4}$ & $9.90 \times 10^{3}$ & $1.41 \times 10^{3}$ \\
\hline 19 & 17.9 & 17.6 & $1.53 \times 10^{6}$ & $3.97 \times 10^{6}$ & $2.44 \times 10^{6}$ & $>2.00 \times 10^{4}$ \\
\hline 20 & 29.5 & 28.2 & $5.62 \times 10^{2}$ & $2.98 \times 10^{3}$ & $2.42 \times 10^{3}$ & $7.95 \times 10^{2}$ \\
\hline 21 & 23.6 & 23.4 & $3.07 \times 10^{4}$ & $7.34 \times 10^{4}$ & $4.27 \times 10^{4}$ & $1.37 \times 10^{4}$ \\
\hline 22 & 38.2 & + & + & + & + & Negative \\
\hline 23 & Negative & Negative & Negative & Negative & Negative & Negative \\
\hline 24 & 28.1 & 27.9 & $1.39 \times 10^{3}$ & $3.98 \times 10^{3}$ & $2.58 \times 10^{3}$ & $6.35 \times 10^{2}$ \\
\hline 25 & 31.3 & 30.2 & $1.58 \times 10^{2}$ & $7.19 \times 10^{2}$ & $5.61 \times 10^{2}$ & $7.45 \times 10^{2}$ \\
\hline 26 & 25.0 & 24.7 & $1.15 \times 10^{4}$ & $3.07 \times 10^{4}$ & $1.92 \times 10^{4}$ & $8.95 \times 10^{2}$ \\
\hline 27 & 35.8 & 39.0 & + & + & + & Negative \\
\hline 28 & Negative & + & Negative & + & Only + wo/ PMA & Negative \\
\hline 29 & Negative & + & Negative & + & Only + wo/ PMA & Negative \\
\hline 30 & 28.5 & 27.9 & $1.07 \times 10^{3}$ & $3.37 \times 10^{3}$ & $2.29 \times 10^{3}$ & $1.19 \times 10^{3}$ \\
\hline 31 & 26.0 & 24.9 & $5.85 \times 10^{3}$ & $2.42 \times 10^{4}$ & $1.83 \times 10^{4}$ & $4.70 \times 10^{3}$ \\
\hline 32 & 29.3 & 28.0 & $6.21 \times 10^{2}$ & $3.03 \times 10^{3}$ & $2.41 \times 10^{3}$ & $9.85 \times 10^{2}$ \\
\hline 33 & 25.3 & 24.0 & $9.48 \times 10^{3}$ & $4.61 \times 10^{4}$ & $3.66 \times 10^{4}$ & $1.70 \times 10^{4}$ \\
\hline 34 & 31.3 & 29.4 & $1.61 \times 10^{2}$ & $1.14 \times 10^{3}$ & $9.83 \times 10^{2}$ & $7.15 \times 10^{2}$ \\
\hline 35 & 28.2 & 26.9 & $1.42 \times 10^{3}$ & $6.28 \times 10^{3}$ & $4.87 \times 10^{3}$ & $4.40 \times 10^{3}$ \\
\hline 36 & 26.4 & 25.1 & $4.35 \times 10^{3}$ & $2.39 \times 10^{4}$ & $1.95 \times 10^{4}$ & $1.09 \times 10^{4}$ \\
\hline 37 & 28.1 & 27.5 & $1.42 \times 10^{3}$ & $4.40 \times 10^{3}$ & $2.99 \times 10^{3}$ & $3.30 \times 10^{3}$ \\
\hline 38 & 28.3 & 27.0 & $1.32 \times 10^{3}$ & $5.93 \times 10^{3}$ & $4.61 \times 10^{3}$ & $2.00 \times 10^{3}$ \\
\hline 39 & 29.6 & 34.9 & $6.13 \times 10^{2}$ & + & + & Negative \\
\hline 40 & 32.5 & 31.7 & + & $2.40 \times 10^{2}$ & + & $2.50 \times 10^{1}$ \\
\hline 41 & Negative & Negative & Negative & Negative & Negative & Negative \\
\hline 42 & Negative & + & Negative & + & Only + wo/ PMA & Negative \\
\hline 43 & 29.0 & 28.4 & $7.67 \times 10^{2}$ & $2.29 \times 10^{3}$ & $1.52 \times 10^{3}$ & $1.75 \times 10^{3}$ \\
\hline 44 & 33.8 & 30.5 & + & $5.34 \times 10^{2}$ & + & $1.95 \times 10^{2}$ \\
\hline 45 & 28.2 & 28.4 & $1.36 \times 10^{3}$ & $2.30 \times 10^{3}$ & $9.42 \times 10^{2}$ & $9.20 \times 10^{2}$ \\
\hline 46 & 23.2 & 23.0 & $3.91 \times 10^{4}$ & $9.57 \times 10^{4}$ & $5.65 \times 10^{4}$ & $2.70 \times 10^{4}$ \\
\hline 47 & 27.5 & 25.9 & $2.08 \times 10^{3}$ & $1.47 \times 10^{4}$ & $1.26 \times 10^{4}$ & $3.15 \times 10^{3}$ \\
\hline 48 & 27.1 & 26.3 & $2.82 \times 10^{3}$ & $1.16 \times 10^{4}$ & $8.75 \times 10^{3}$ & $1.90 \times 10^{3}$ \\
\hline 49 & 27.7 & 26.2 & $1.85 \times 10^{3}$ & $1.28 \times 10^{4}$ & $1.10 \times 10^{4}$ & $4.70 \times 10^{3}$ \\
\hline 50 & 27.4 & 27.4 & $2.38 \times 10^{3}$ & $4.52 \times 10^{3}$ & $2.15 \times 10^{3}$ & $2.05 \times 10^{3}$ \\
\hline
\end{tabular}


w/ PMA: PMA-treatment prior to DNA extraction and Q-PCR

wo/ PMA: No PMA-treatment

CCE: Campylobacter cell equivalents

+: Campylobacter-positive below the quantification limit 
Figure 1. Standard curves produced from ten-fold serial dilutions ranging from $1 \times 10^{2}$ to $1 \times 10^{6}$ $\mathrm{CFU} / \mathrm{ml}$ chicken carcass rinse of (A): C. jejuni CCUG 11284 and (B): C. coli CCUG 11283 cells in six different chicken carcass rinses, showing the variation that can be ascribed to the matrix. Each data point represents three biological and six Q-PCR replicates.

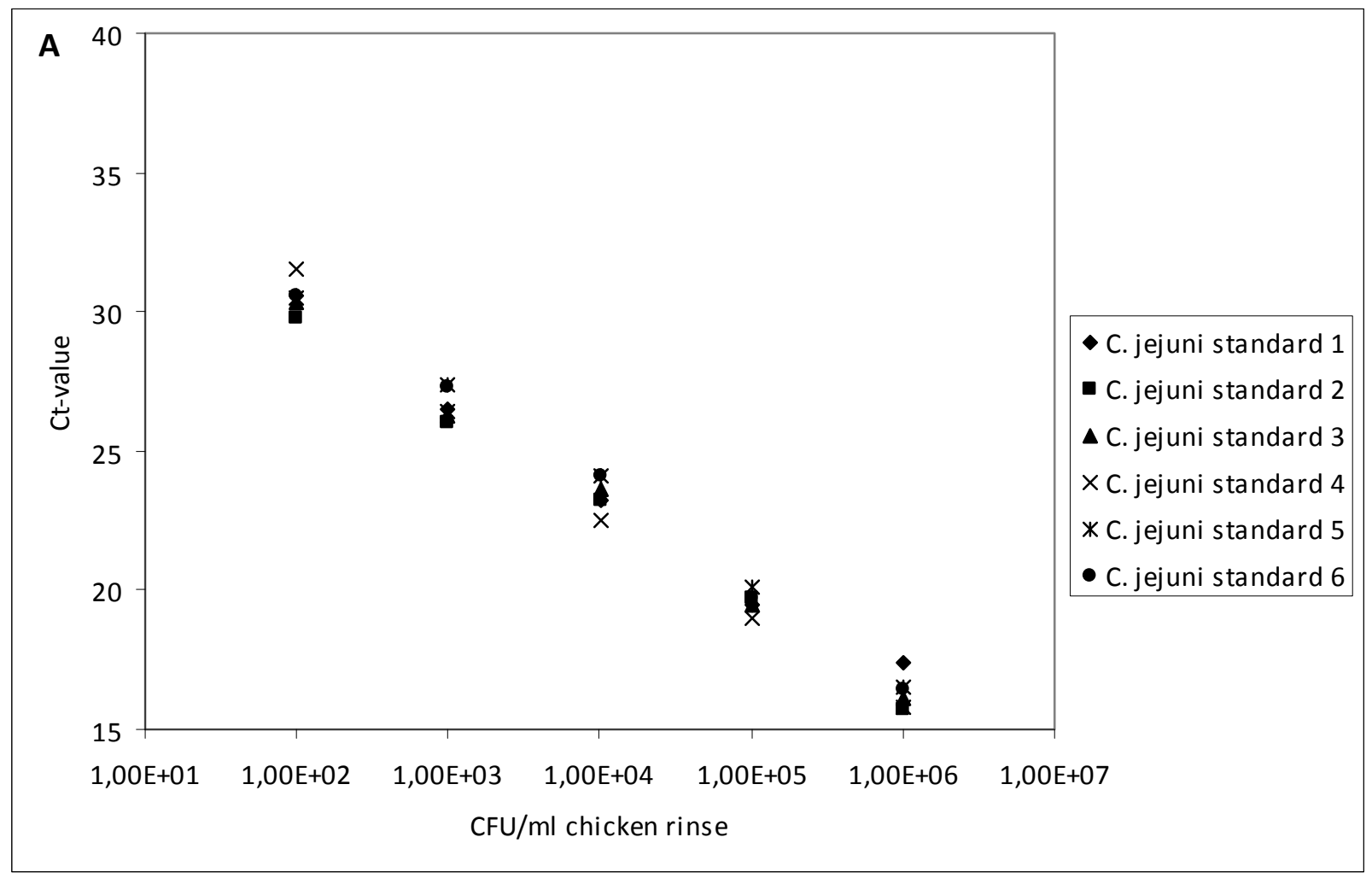




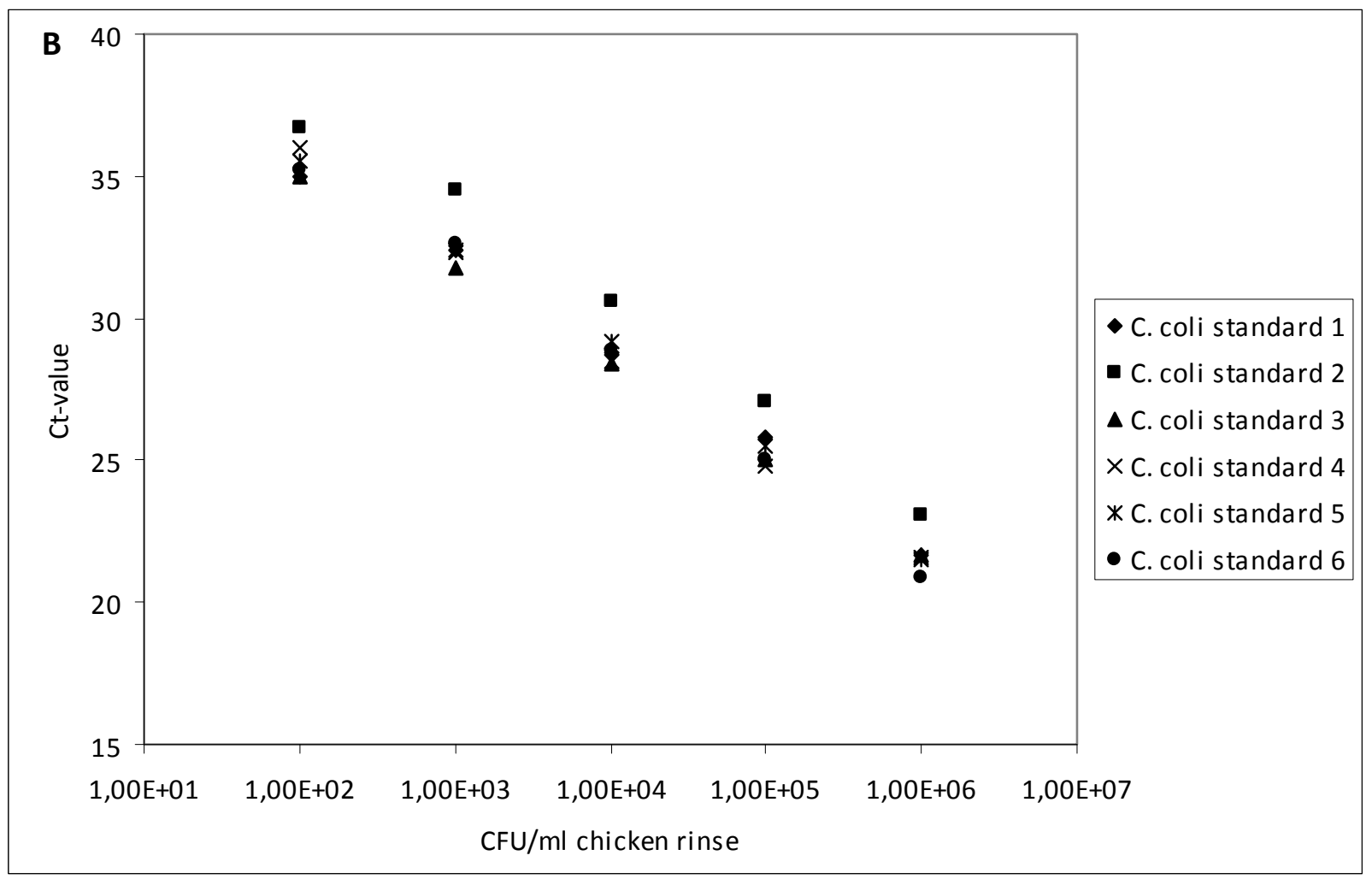


Figure 2. Standard curves produced from ten-fold serial dilutions ranging from $1 \times 10^{-4}$ to $1 \times 10^{1} \mathrm{ng}$ DNA/PCR of C. jejuni CCUG 12795 and 14539, C. coli CCUG 10951 and 12791 and C. lari CCUG 20707 and 23947, showing the variation that can be ascribed to the species on DNA level. Each data point represents two Q-PCR replicates.

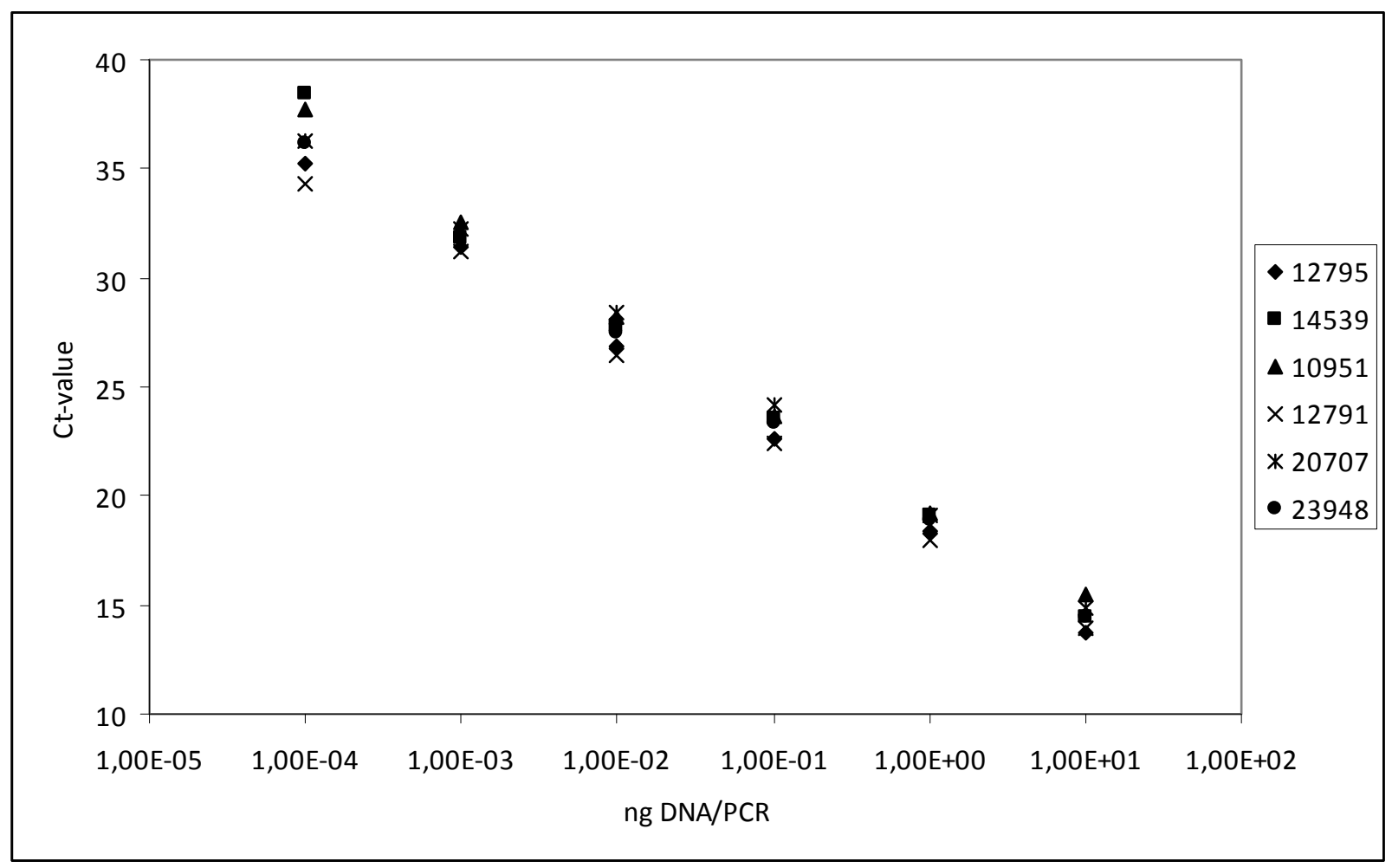


Figure 3. Standard curves produced from ten-fold serial dilutions ranging from $1 \times 10^{1}$ to $1 \times 10^{6}$ CFU/ml of C. jejuni CCUG $11284(n=4)$, C. coli CCUG $11283(n=2)$ and C. lari CCUG $23947(n=2)$, showing the variation that can be ascribed to the species on cell level. Not to camouflage the variation between species $\Delta \mathrm{Ct}$-values were applied to standardize the amount of input cells, by subtracting the Ct-value for each cell level from the Ct-value obtained for $1 \times 10^{6} \mathrm{CFU} / \mathrm{ml}$. Each data point represents two biological and two Q-PCR replicates.

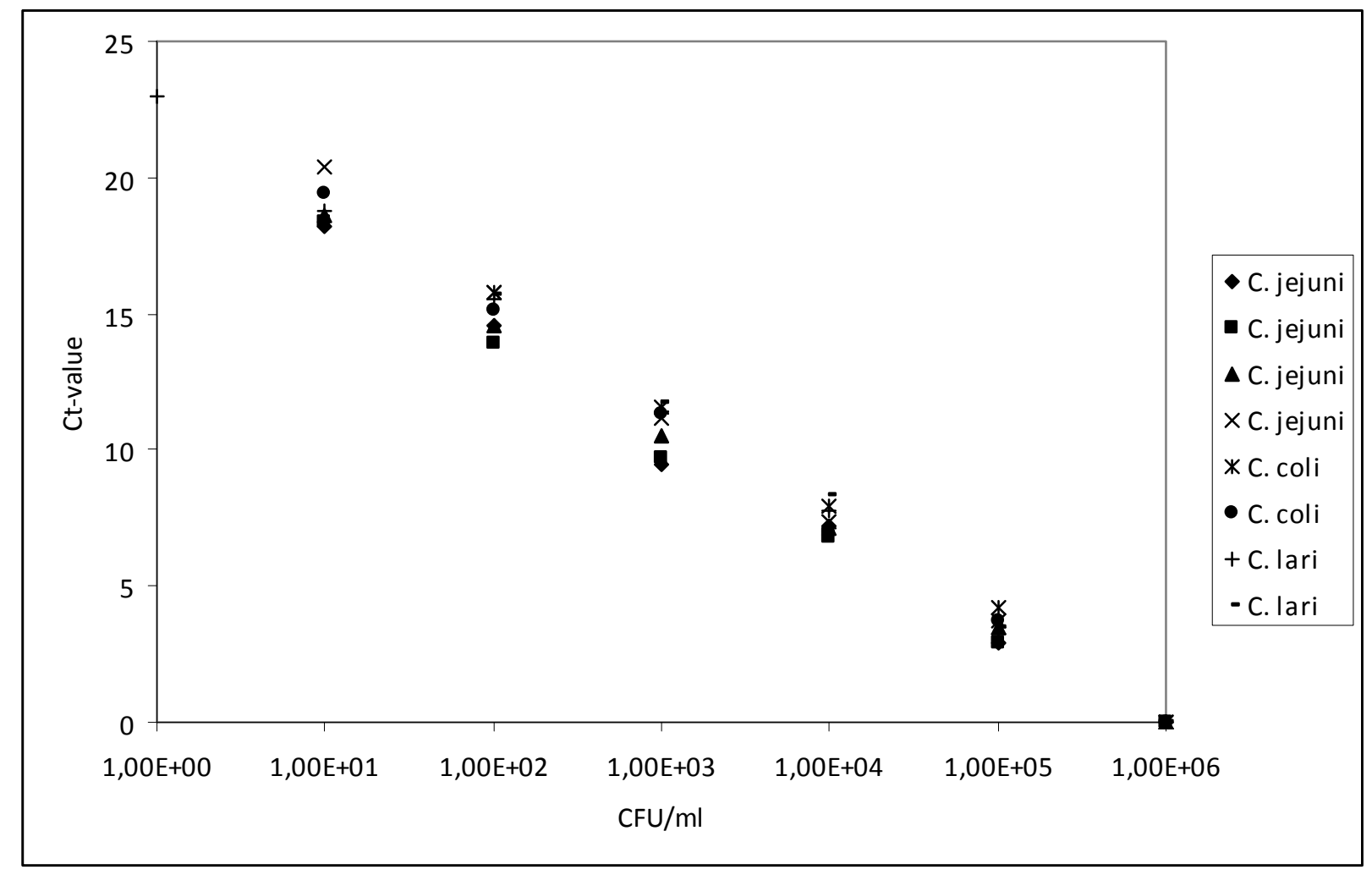


Figure 4. Correlation of Campylobacter quantitative results obtained by Q-PCR with (A) and without (B) PMA-treatment and culture on naturally contaminated chicken carcass rinse samples.
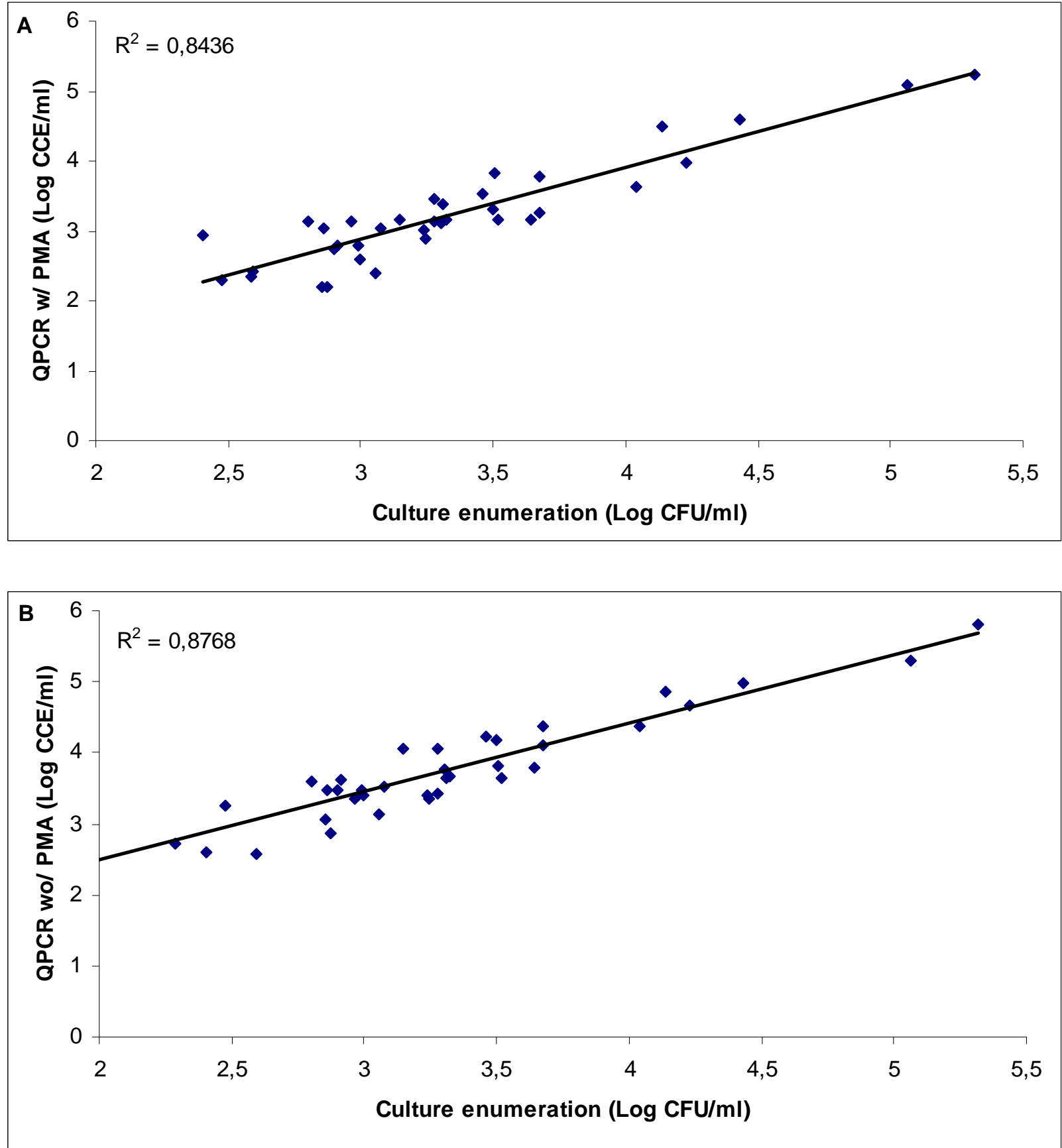